\title{
Regional Integration, Human Rights and Democratic Participation in Africa
}

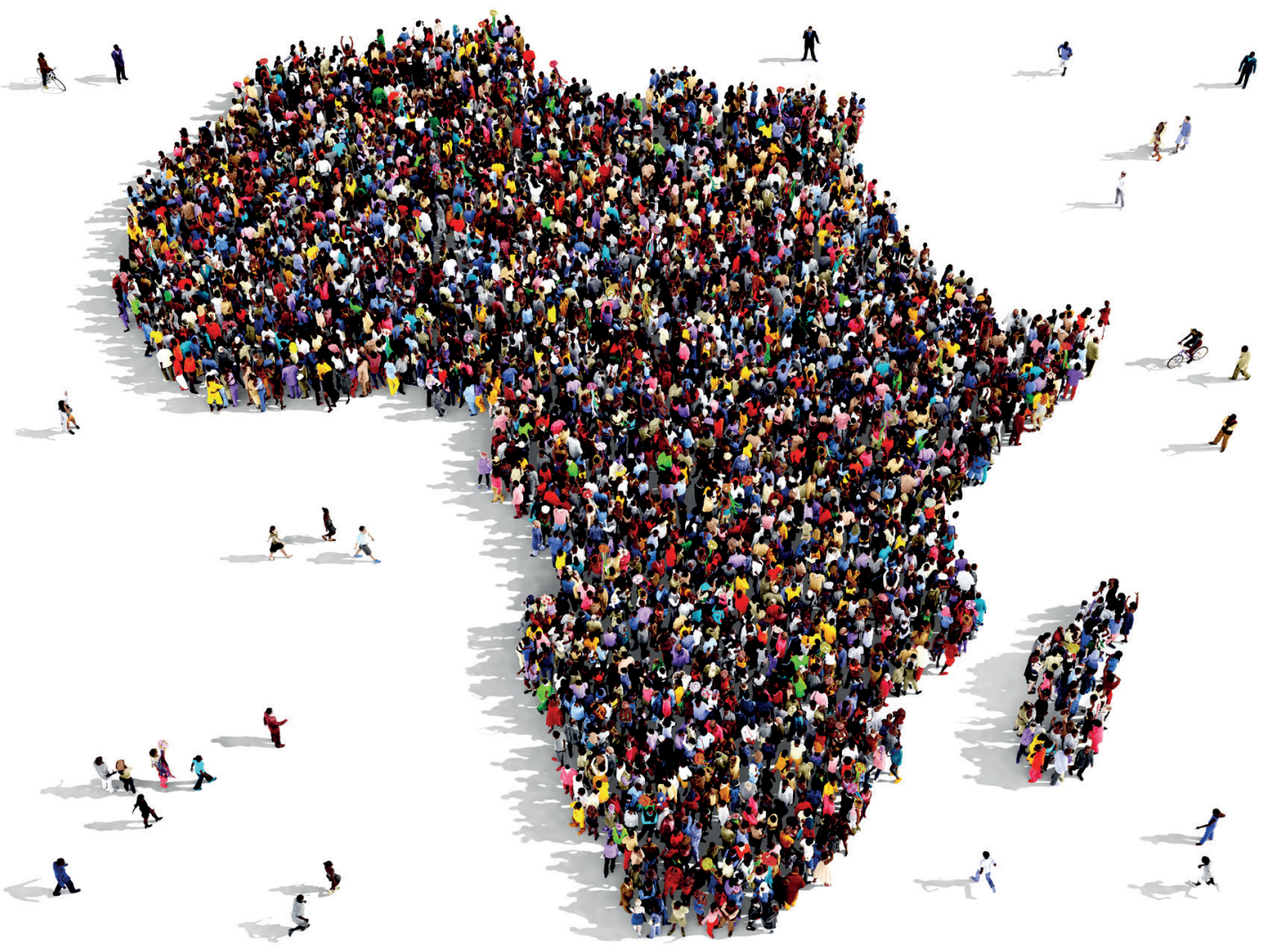

\section{Universitätsdrucke Göttingen}



Karin Deichmann

Regional Integration, Human Rights and Democratic Participation in Africa

This work is licensed under a Creative Commons Attribution-ShareAlike 4.0 International License.

(c) (P) (?) 
erschienen in der Reihe der Universitätsdrucke im Universitätsverlag Göttingen 2020 
Karin Deichmann

Regional Integration, Human Rights and Democratic Participation in Africa

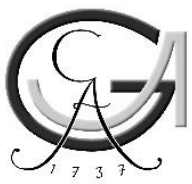

Universitätsverlag Göttingen 2020 
Bibliographic information published by the Deutsche Nationalbibliothek

The Deutsche Nationalbibliothek lists this publication in the Deutsche

Nationalbibliografie; detailed bibliographic data are available on the Internet at

$<$ http://dnb.dnb.de $>$.

Dissertation, Georg-August-Universität Göttingen

\section{Contact}

Karin Deichmann

E-Mail: ks.deichmann@gmail.com

This work is protected by German Intellectual Property Right Law.

It is also available as an Open Access version through the publisher's homepage and the Göttingen University Catalogue (GUK) at the Göttingen State and University Library (https://www.sub.uni-goettingen.de).

The conditions of the license terms of the online version apply.

Typesetting and layout: Sascha Bühler

Cover image: Arthimedes/Shutterstock.com

(C) 2020 Universitätsverlag Göttingen

https:/ / univerlag.uni-goettingen.de

ISBN: $978-3-86395-468-0$

DOI: https://doi.org/10.17875/gup2020-1339 


\section{Vorwort}

Diese Arbeit wurde im Juli 2020 als Dissertation an der Juristischen Fakultät der Georg-August-Universität Göttingen angenommen. Rechtsprechung und Literatur wurden bis September 2018 berücksichtigt.

Mein besonderer Dank gilt meinem Doktorvater Herrn Prof. Dr. Peter-Tobias Stoll für seine vielseitigen Hilfestellungen bei der Themenfindung. Ferner haben die regelmäßigen Gespräche, Hinweise und intensiven Diskussionen während des Entstehungsprozesses der Arbeit wesentlich zu deren erfolgreichen Abschluss beigetragen.

Ich danke zudem Prof. Dr. José Martinez für die zügige Anfertigung des Zweitvotums.

Meinen Eltern Artur und Andrea Deichmann sowie meinen Geschwistern Maximilian und Constantin Deichmann danke ich für die uneingeschränkte Unterstützung während des Studiums, des Promotionsvorhabens und des Referendariates.

Schließlich danke ich meinen Freunden sowie dem Rest der Familie, die mir während der Umsetzung des Promotionsvorhabens stets auf verschiedenste Weise zur Seite standen.

Berlin, im Oktober 2020 



\section{Table of content}

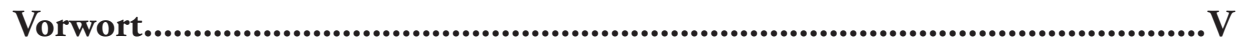

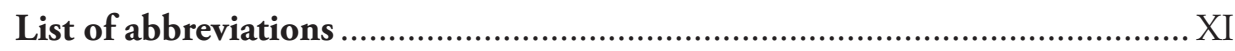

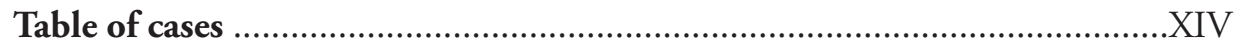

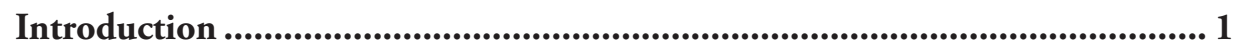

Chapter 1: Developments towards regional integration in Africa....................... 3

1.1 The establishment of the United Nations - a milestone

for the international recognition of human rights .................................... 3

1.2 The United Nations and regional integration .......................................... 6

1.3 The concept of Pan-Africanism as an example of regionalism .................... 7

Chapter 2: Integration at regional level - the African Union (AU) .................... 9

2.1 Historical background: from the Organization of African Unity

(OAU) to the African Union (AU) .......................................................... 10

2.2 Purposes and achievements of the African Union (AU) - winds

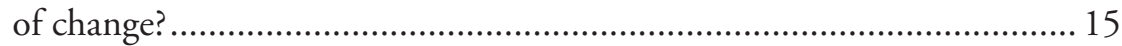

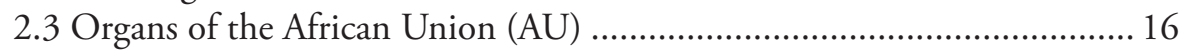

2.4 Human Rights wing of the African Union (AU) ..................................... 20

2.4.1 Human Rights instruments of the African Union (AU) ................ 20

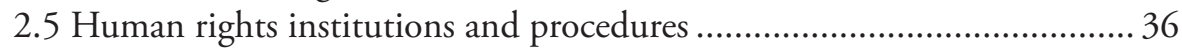

2.5.1 The African Commission on Human and Peoples' Rights ............... 36

2.5.2 Conclusion on the African Commission on Human and Peoples' Rights ...................................................................... 52

2.5.3 The African Court on Human and Peoples' Rights ........................ 54

2.5.4 Conclusion African Court on Human and Peoples' Rights.............. 72

2.5.5 The Merger between the African Court of Human and Peoples' Rights and the African Court of Justice ........................................... 74

2.5.6 Conclusion regarding the merge of the African Court of Justice and the African Court on Human and Peoples' Rights.................... 79

2.5.7 The Establishment of the International Criminal Chamber

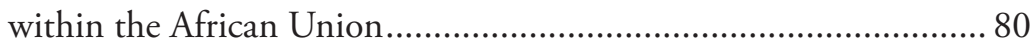

2.5.8 Conclusion on the establishment of the Criminal Chamber within the African Court of Justice and Human and Peoples' Rights............ 94

2.5.9 The Pan-African Parliament (PAP) - capable to guarantee human rights? 
2.5.10 Conclusion on the Pan African Parliament................................. 100

2.6 Conclusion on the Human Rights wing of the African Union (AU) ..... 102

2.7 The economic wing of the African Union (AU) .................................... 104

2.7.1 New Partnership for Africa’s Development (NEPAD) .................... 104

2.7.2 The African Economic Community (AEC) ................................... 107

2.8 Conclusion on the Economic wing of the African Union (AU) .............. 110

2.9 Final conclusion to the African Union (AU) ......................................... 111

Chapter 3: The Protection of human rights on subregional level an introduction ...................................................................................... 113

Chapter 4: The Economic Community of West Africa (ECOWAS)............... 117

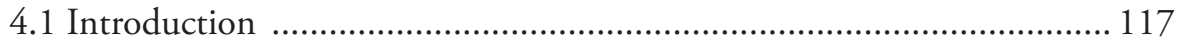

4.2 Historical background on the establishment of Economic

Community of West Africa (ECOWAS) .............................................. 118

4.2.1 First steps until the establishment of the Economic Community of West Africa (ECOWAS) ....................................... 118

4.2.2 The final negotiations towards the adoption of the ECOWAS

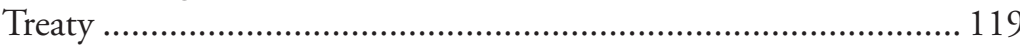

4.3 Purposes and Objectives of the Treaty of the Economic Community

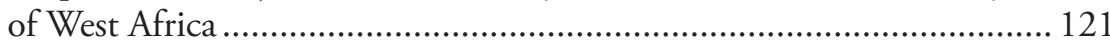

4.4 Organs of the Economic Community of West Africa (ECOWAS) ........ 124

4.5 The Court of the Economic Community of West Africa (ECCJ) .......... 125

4.5.1 The composition of the Court of the Economic Community

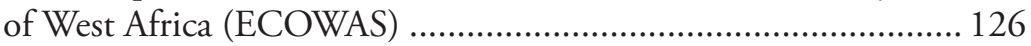

4.5.2 Limited jurisdiction of the Court of the Economic Community of West Africa (ECOWAS) ......................................................... 126

4.5.3 Extension of the jurisdiction of the Court of the Economic Community of West Africa ........................................................ 129

4.6 Enforcement of rulings issued by the ECOWAS Court.......................... 137

4.6.1 ECOWAS Court case law relating to the enforcement ................. 139

4.6.2 Conclusion on the enforcement of rulings ................................... 141

4.6.3 Failed backlash against the ECOWAS Court ............................... 142

4.7 Conclusion on the ECOWAS Court of Justice........................................ 143

4.8 The Parliament of the Economic Community of West Africa................. 145

4.8.1 The Composition of the Parliament of the Economic

Community of West African States - the grounds for an independent institution ............................................................. 145

4.8.2 The internal structure of the Parliament....................................... 146

4.8.3 Engagement with citizens ........................................................ 147

4.8.4 The competences of the ECOWAS Community Parliament ........ 148

4.8.5 The Supplementary Protocol ........................................................ 148 
4.9 Conclusion on the ECOWAS Parliament ………............................... 150

4.10 Final Conclusion on the ECOWAS .................................................... 152

Chapter 5: The Southern African Development Community (SADC) ........ 155

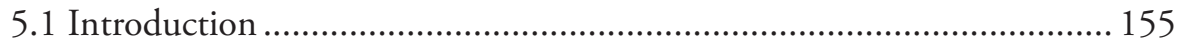

5.2 Historical background of the Southern African Development

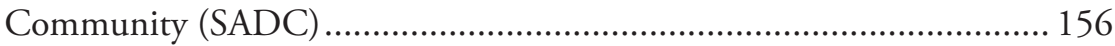

5.3 Objectives of the Southern African Development Community ............ 158

5.4 Organs of the Southern African Development Community (SADC) .... 160

5.5 The Tribunal of the Southern African Development Community ......... 162

5.5.1 Historical Background on the Tribunal of the Southern African Development Community........................................................... 162

5.5.2 Jurisdiction on of the Tribunal of the Southern African Development Community............................................................. 164

5.5.3 The Suspension and establishment of a new SADC Tribunal

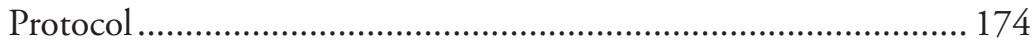

5.6 Conclusion on the Tribunal of the Southern African Development Community (SADC) ......................................................................... 180

5.7 The Parliamentary Forum of the Southern African Development

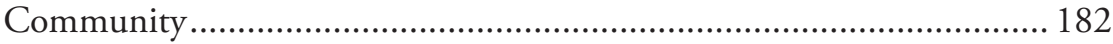

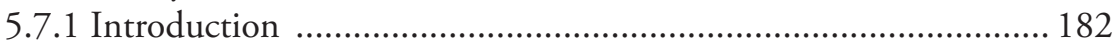

5.7.2 Legal status of the SADC Parliamentary Forum .......................... 183

5.7.3 The composition of the SADC Parliamentary Forum.................... 184

5.7.4 Internal Structure of the SADC Parliamentary Forum .................. 184

5.7.5 Aims and powers of the SADC Parliamentary Forum .................. 185

5.8 Conclusion on the SADC Parliamentary Forum ................................... 188

5.9 Final Conclusion on the Southern African Development Community ..... 190

Chapter 6: The East African Community (EAC) .......................................... 193

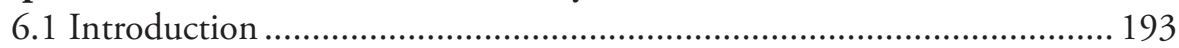

6.2 History of the East African Community .............................................. 194

6.2.1 Regional integration in East Africa under British colonialism....... 194

6.2.2 Decolonization and associated movement to independence

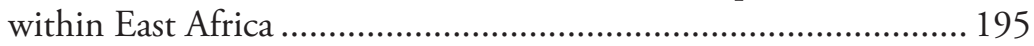

6.3 Objectives of the East African Community (EAC) ................................ 196

6.4 The Organs of the East African Community (EAC) ............................... 197

6.5 Human Rights Protection through the East African Court of Justice ...... 198

6.5.1 The Structure of the East African Court of Justice ....................... 199

6.5.2 Access to the East African Court of Justice..................................... 200

6.5.3 The jurisdictional mandate of the East African Court of Justice ..... 200

6.5.4 New Protocol on Jurisdiction on Human Rights ......................... 205

6.6 Conclusion on the East African Court of Justice ................................. 206 
6.7 The East African Legislative Assembly................................................... 208

6.7.1 The internal composition of the Legislative Assembly of the East African Community ........................................................ 208

6.7.2 The mandate of the East African Legislative Assembly ................. 212

6.7.3 The proposal of a Human and Peoples' Rights Bill ....................... 215

6.8 Conclusion on the East African Parliament............................................ 216

6.9 Final Conclusion on the East African Community................................. 217

\section{Chapter 7: Common Market of Eastern and Southern Africa}

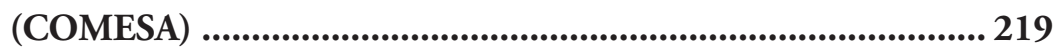

7.1 Introduction

7.2 Historical background of the Common Market for Eastern and

Southern Africa

7.3 Objectives of the Common Market for Eastern and Southern Africa ... 223

7.4 Organs of the Common Market of Eastern and Southern Africa (COMESA).

7.5 The Court of Justice of the Common Market for Eastern and Southern Africa 225

7.5.1 Introduction

7.6 Conclusion on the Court of the Common Market of Eastern and Southern Africa.

7.7 Committees of the Common Market of Eastern and Southern Africa

(COMESA)

7.7.1 Technical Committees of the Common Market of Eastern and Southern Africa (COMESA)

7.7.2 Consultative Committee of the Common Market of Eastern and Southern Africa (COMESA)

7.7.3 Intergovernmental Committee of the Common Market of Eastern and Southern Africa

7.8 Conclusion on the Committees of the Common Market of Eastern and Southern Africa 240

7.9 Final Conclusion on the Common Market of Eastern and Southern Africa 241

Chapter 8: Conclusion

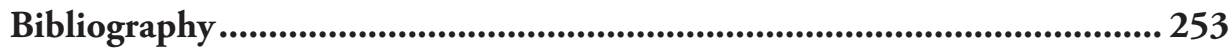

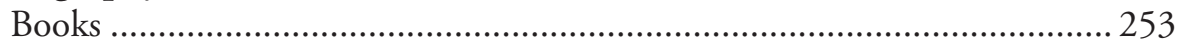

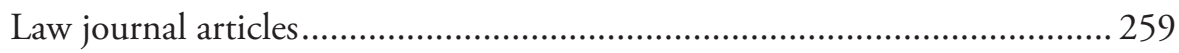

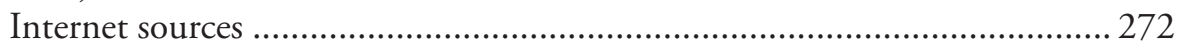




\section{List of abbreviations}

$\begin{array}{ll}\text { ACB } & \text { African Central Bank } \\ \text { ACIDH } & \text { Action-Against Impunity and Human Rights } \\ \text { ACHPR } & \text { African Commission on Human and Peoples' Rights } \\ \text { ACJ } & \text { African Court of Justice } \\ \text { ACRWC } & \text { African Charter on the Rights and Welfare of the Child } \\ \text { AEC } & \text { African Economic Community } \\ \text { AHRLR } & \text { African Human Rights Law Reports } \\ \text { AHSG } & \text { Assembly of Heads of State and Government } \\ \text { AIB } & \text { African Investment Bank } \\ \text { AIDS } & \text { Acquired Immune Deficiency Syndrome } \\ \text { AMF } & \text { African Monetary Fund } \\ \text { APRM } & \text { African Peer Review Mechanism } \\ \text { APSA } & \text { The African Peace and Security Architecture } \\ \text { Art. } & \text { Article } \\ \text { Arts. } & \text { Articles } \\ \text { ASEAN } & \text { Association of Southeast Asian Nations } \\ \text { AU } & \text { African Union } \\ \text { CCJ } & \text { Common Market of Eastern and Southern Africa Court } \\ & \text { of Justice } \\ \text { CCM } & \text { Chama Cha Mapinduzi } \\ \text { CEDAW } & \text { Convention on the Elimination of All Forms of Discrimination } \\ & \text { against Women } \\ \text { CHOGS } & \text { Commonwealth Heads of Governments and States } \\ \text { COMESA } & \text { Common Market of Eastern and Southern Africa } \\ \text { CPPCG } & \text { Convention on the Prevention and Punishment of the Crime } \\ & \text { of Genocide } \\ \text { CRC } & \text { Convention on the Rights of the Children } \\ \text { CU } & \text { Customs Union } \\ \text { CUF } & \text { Civic United Front } \\ \text { Dr. } & \text { Doctor } \\ \text { EAC } & \text { East African Community } \\ \text { EACJ } & \text { East African Court of Justice } \\ \text { EADB } & \text { East African Development Bank } \\ \text { EALA } & \text { East African Legislative Assembly } \\ \text { EALS } & \text { East African Law Society } \\ \text { EBID } & \text { ECOWAS Bank for Investment and Development } \\ \text { ECCJ } & \text { ECOWAS Court of Justice } \\ \text { ECHR } & \text { European Human Rights Convention } \\ \text { ECA } & \text { UN Economic Commission for Africa } \\ \text { ECOMOG } & \text { ECOWAS Monitoring Group } \\ & \end{array}$




\begin{tabular}{ll} 
ECOSOC & Economic and Social Commission \\
ECOWAS & Economic Community of West Africa \\
EU & European Union \\
FEMCOM & Federation of National Associations of Women in Business \\
FSIA & South African Foreign States Immunities Act \\
FTA & Free Trade Area \\
GATT & General Agreement on Tariffs and Trade \\
GATS & General Agreement on Trade in Services \\
HIV & Human Immunodeficiency Virus \\
ICC & International Criminal Court \\
ICESCR & International Covenant on Economic, Social and Cultural Rights \\
ICJ & International Court of Justice \\
ICCPR & International Covenant on Civil and Political Rights \\
ICTR & The International Criminal Court for Rwanda \\
IGAD & International Authority on Development \\
IMF & International Monetary Fund \\
ITLOS & International Tribunal for the Law of the Sea \\
LURD & Liberians United for Reconciliation and Democracy \\
MDG & United Nations Millennium Goals \\
MFN & Most Favored Nation \\
MINURSO & United Nations Mission for the Referendum in Western Sahara \\
MP & Member of Parliament \\
MULPOCS & Multinational Programming and Operational Centres \\
NATO & North Atlantic Treaty Organization \\
NCCR-M & National Convention for Construction and Reform-Mageuzi \\
NEPAD & New Partnership for Africas Development \\
NGO & Non-Governmental Organization \\
No. & Number \\
OAU & Organization of African Unity \\
OECD & Economic Co-operation and Development \\
OPDS & Organ on Politics, Defence and Security \\
PAP & Pan African Parliament \\
PSC & Peace and Security Council \\
PTA & Preferential Trade Area \\
PvT LTD & Private Limited Company \\
RADDHO & Rencontre africaiane pour la défence des droits de l'Homme \\
REC & Regional Economic Community \\
RISDP & Regional Indicative Strategic Development Plan \\
RTA & Regional Trade Agreement \\
SACU & Southern African Customs Union \\
SADC & Southern African Development Community \\
SADC-PF & SADC Parliamentary Forum \\
\hline
\end{tabular}




$\begin{array}{ll}\text { SADCC } & \text { Southern African Development Coordination Conference } \\ \text { SALC } & \text { Southern African Litigation Centre } \\ \text { SCA } & \text { Supreme Court of Appeal South Africa } \\ \text { SCC } & \text { Special Criminal Court } \\ \text { SERAC } & \text { Social and Economic Rights Action Centre } \\ \text { SERAP } & \text { Socio-Economic Rights and Accountability Project } \\ \text { TEU } & \text { Treaty on European Union } \\ \text { TFEU } & \text { Treaty on the Functioning of the European Union } \\ \text { TFTA } & \text { Tripartite Free Trade Area } \\ \text { v. } & \text { versus } \\ \text { VCLT } & \text { 1969 Vienna Convention on the Law of the Treaties } \\ \text { UDHR } & \text { Universal Declaration of Human Rights } \\ \text { UK } & \text { United Kingdom } \\ \text { UN } & \text { United Nations } \\ \text { UN-HABITAT } & \text { United Nations Human Settlements Programme } \\ \text { UNAMID } & \text { African Union United Nations Mission in Darfur } \\ \text { UNEP } & \text { United Nations Environment Programme } \\ \text { UNGA } & \text { United Nations General Assembly } \\ \text { UNHCHR } & \text { United Nations High Commissioner for Human Rights } \\ \text { UNHCR } & \text { UN Refugee Agency } \\ \text { UNITA } & \text { Angolan Rebel Group } \\ \text { UNSOS } & \text { United Nations Support Office in Somalia } \\ \text { US } & \text { United States } \\ \text { WAEON } & \text { West Africa Elections Observations Network }\end{array}$




\section{Table of cases}

\section{African Commission on Human and Peoples' Rights}

(Communications are reported at the Homepage of the African Commission: http://www.achpr.org/search/)

Anuak Justice Council v. Ethiopia, Communication No:. 229/2005, Date of Communication: 25 May 2006.

Bakweri Land Claims Committee v. Cameroon, Communication No.: 260/02, Date of Communication: 4 December 2004.

Constitutional Rights Project v. Nigeria, Communication No.: 102/93, Date of Communication: 31 October 1998.

Democratic Republic of Congo v. Burundi, Rwanda and Uganda, Communication No.: 227/99, Date of Communication: 29 May 2003.

International PEN and Others (on behalf of Saro-Wiwa) v. Nigeria, Communication No.: 137/94, Date of Communication: 31 October 1998.

Institute for Human Rights and Development in Africa and Others v. Democratic Republic of Congo, Communication No. 393/10, Date of Communication: 18 June 2016.

Legal Resources Foundation v. Zambia, Communication No.: 211/98, Date of Communication: 07 May 2001.

Luke Munyandu Tembani and Benjamin John Freeth (represented by Norman Tjombe) v. Angola and Thirteen Others, Communication No. 409/12, Date of Communication: 30 April 2014.

Malawi African Association and Others v. Mauritania, Communication Nos.: 54/91, 61/91, 98/93, 164/97 à 196/97 and 210/98, Date of Communication: 11 May 2000.

Media Rights Agenda and Others v. Nigeria, Communication Nos.: 105/93, 128/94, 130/94 and 152/96, Date of Communication: 31 October 1998.

Mohamed L. Diakité v. Gabon, Communication No.: 73/92, Date of Communication: 27 April 1994.

Mohamed El-Nekheily v. OAU, Communication No.: 12/88, Date of Communication: 26 October 1988.

Prince v. South Africa, Communication No.: 255/2002, Date of Communication; 7 December 2004.

Purohit and Moore v. The Gambia, Communication No.: 241/01, Date of Communication: 29 May 2003.

RHADDO v. Zambia, Communication No.: 71/92 Date of Communication: 31 October 1996. 
Samuel T. Muzerengwa \& 110 Others v. Zimbabwe, Communication No.: 306/05, Date of Communication: 3 March 2011.

The Social and Economic Rights Action Center and the Center for Economic and Social Rights v. Nigeria, Communication No.: 155/96, Date of Communication: 27 October 2001.

\section{African Court of Human and Peoples' Rights}

(Decisions are reported at the Homepage of the African Court of Human and Peoples' Rights)

African Commission on Human and Peoples' Rights v. Great Social People's Libyan Arab Jamahiriya, App. No.: 004/2011, Date of Judgment, 15 March 2013.

African Commission on Human and Peoples' Rights v. Republic of Kenya, App. No.: 006/2012, Date of Judgment: 26 May 2017.

Anudo Ochieng Anudo v. The Republic of Tanzania, App. No.: 012/2015, Date of Judgment: 22 March 2018.

Association pour le progres et la Defénse des Droits de Femmes Maliennes and the Institute for Human Rights and Developments v. the Republic Mali, App. No.: 046/2016, Date of Judgment: 11 May 2018.

Baghadadi Ali Mahmouid v. The Republic of Tunisia, App. No.: 007/2012, Date of Judgment: 26 June 2012.

Cameroon and Association Juristes d'Afrique pour la Bonne Gouvernance v. République de Côte d'Ivoire, App. No.: 006/2011, Date of Judgment: 16 June 2011.

Daniel Amare and Mulugeta Amare v Republic of Mozambique \& Mozambique Airlines, App. No.: 002/2011, Date of Judgment: 16 June 2011.

Delta International Investments and Others v. The Republic of South Africa and Emmanuel Joseph Uko and Others v The Republic of South Africa, App. No.: 002/2012, Date of Judgment: 30 March 2012.

Efoua Mbozoo Samuel v The Pan African Parliament, App. No: 010/2011, Date of Judgment: 30 September 2011.

Ekollo M. Alexandre v. Republic of Cameroon and Federal Republic of Nigeria, App. No.: 008/2011, Date of Judgment: 23 September 2011.

Emmanuel Joseph Uko v. The Republic of South Africa, App. No.: 004/2012, Date of Judgment: 13 March 2012.

Femi Falana v. African Union, App. No.: 001/2011, Date of Judgment: 26 June 2012.

Michaelot v. Yugogombaye v. The Republic of Senegal, App. No.: 1/2008, Date of Judgment: 15 September 2009. 
Soufiane Ababou v. People's Democratic Republic of Algeria, App. No.: 005/2011, Date of Judgment: 20 October 2016.

\section{Constitutional Court of the Republic of South Africa}

(Decision reported at the Homepage of the Southern African Legal

Information Institute: http://www.saflii.org)

Government of the Republic of Zimbabwe v. Fick and Others, Appl. No.: CCT 101/12, Date of Judgment: 27 June 2013.

National Commissioner of the South African Police Service v. Southern African Human Rights Litigation Centre and another, Appl. No.: CCT 02/14, Date of Judgment: 30 October 2014.

\section{Constitutional Court of the Republic of Zimbabwe}

(Decisions reported at the Homepage of the Constitutional Court of Zimbabwe: https://zimlii.org/zw/judgments/constitutional-court)

Commercial Farmers Union and Others v. The Minister of Lands and Rural Resettlement and Others, Appl. No.: 81/10, Date of Judgment: 26 November 2010.

Mike Campbell (Pty) Ltd. v. Minister of National Security Responsible for Land, Land Reform and Resettlement Appl. No.: Const.124/06, Date of Judgment: 21 January 2008.

\section{Court of Appeal of England and Wales (Criminal Division)}

(Decision reported at the Homepage of the World Legal Information Institute: www.worldlii.org)

Regina v. Horseferry Road Magistrates' Court and another, ex parte Bennett, [1994] 1 A.C. 42.

\section{Court of Appeal of the Republic of Nigeria}

(Decisions reported at International Centre for Nigerian Law:

https://nigerialii.org/ng/judgment/supreme-court/2000/17)

Okogie v. Attorney General of Lagos State, App. No.: (1981) 1 NCLR 218.

Oronto Douglas v. Shell Petroleum Development Company Limited,

App. No.: CA/L/143/97, Date of Judgment 15 December 1998.

\section{Court of Justice of the Common Market of Eastern and Southern Africa}

(Decisions are reported at the Homepage of the COMESA Court: https://comesacourt.org/court-decisions/)

Eastern and Southern African Trade and Development Bank v. Martin Ogang, Appl. No.: 1B/ 2000, Date of Judgment: 26 April 2002.

Intesolmac (Uganda) Limited v. Rwanda Civil Aviation Authority, Appl. No. 1 of 2009, Date of Judgement: 7 May 2010.

Kenya and the Commissioner of Lands v. Coastal Aquaculture, Appl. No.:

3/2001, Date of Judgment: 26 April 2002. 
Malawi Mobile Ltd. v. Government of the Republic of Malawi and the Malawi Communications Regulatory, Appeal 1 of 2016, Date of Judgement: 22 June 2016.

Polytol Paints v. Mauritius, Reference No. 1 of 2012, Date of Judgment: 1 December 2012.

PTA Bank v. Yvonne Nyagamukenga, Reference No: 03/2006, Date of Judgment: 18 September 2009.

\section{Court of Justice of the Economic Community of West Africa}

(Decisions are reported at the Homepage of the ECOWAS Court:

http://prod.courtecowas.org/decisions-3/)

Chief Ebrimah Manneh v. The Republic of The Gambia (2008), Appl. No.: ECW/CCJ/APP/04/07, Date of Judgment: 5 June 2008.

Peter David v. Ralph Uwechue, Appl. No.: ECW/CCJ/RUL03/10, Date of Judgment: 11 June 2010.

Federation of African Journalists and Others v. The Republic of The Gambia, Appl. No.: ECW/CCJ/APP/36/15, Date of Judgment: 13 March 2018.

Hadijatou Mani v. Republic of Nigeria, Appl. No.: ECW/CCJ/APP/08/08, Date of Judgment: 27 October 2008.

Hissein Habré v. Republic of Senegal, Appl. No.: ECW/CCJ/APP/07/08, Date of Judgment: 18 November 2010.

Jerry Ugokwe v. Federal Republic of Nigeria and Others, Appl. No.: ECW/ CCJ/APP/06/14, Date of Judgment: 30 November 2015.

Olajude Afolabi v. Federal Republic of Nigeria, Appl. No.: ECW/CCJ/ JUD/01/04, Date of Judgment: 27 April 2004.

SERAP v. Federal Republic of Nigeria, Appl. No.: ECW/CCJ/APP/08/08, Date of Judgment: 27 October 2009.

SERAP v. Federal Republic of Nigeria, Appl. No. ECW/CCJ/APP/08/09, Date of Judgment: 10 December 2010.

\section{East African Community Court}

(Decisions are reported at the Homepage of the EAC Court: https:// www.eacj.org/)

Burundian Journalists Union v. The Attorney General of the Republic of Burundi, App. No.: 7 of 2013, Date of Judgment: 15 May 2015.

Calist Andrew Mwatela \& Others v. East African Community, Taxation Number: 1 f 2006, date of Judgment: 1 November 2007.

Chude Mba v. The Republic of Ghana, Appl. No. ECW/CCJ/APP/01/13, Date of Judgment: 06 November 2013.

Democratic Party v. The Secretary General of the East African Community, Appeal No.: 1 of 2014, Date of Judgment 28 July 2015. 
East African Law Society and Others v. Attorney General of the Republic of Kenya, Appl. No.: 3/2007, Date of Judgment, 1 September 2008.

Hon. Sitenda Sebalu v. The Secretary General of the East African Community, Reference No.: 8 of 2012, Date of Judgment: 22 December 2013.

Independent Medical Legal Unit v. the Attorney-General of Kenya, Appl. No.: 3 of 2010, Date of Judgment: 15 March 2012.

James Katabazi and 21 Others v. Secretary General of the East African Community and another, App. No.: 1 of 2007, Date of Judgment: 31 October 2007.

Prof. Anyang'Nyong'o and Ten others v. Attorney General of the Republic of Kenya and Five Others, App. No.: 1 of 2006, Date of Judgment: 29 March 2007.

\section{European Court of Human Rights}

(Decisions reported at the Homepage of the European Court:

https:/www.echr.coe.int/Pages/home.aspx?p=caselaw/HUDOC\&c=)

De Wilde, Oms and Versyp v. Belgium Series, A No. 12, Appl. Nos.: 2832/66; 2835/66; 2899/66, Date of Judgment, 18 November 1970.

Lawless v. Ireland, Appl. No.: 3, Date of Judgment: 1 July 1961.

\section{High Court of North Gauteng, Republic of South Africa}

(Decisions reported at the Homepage of the Southern African Legal

Information Institute: www.saflii.org)

Government of the Republic of Zimbabwe v. Fick and Others, Application No. 47954/2011, ZAGPPHC 76, Date of Judgment: 06 June 2011.

Law Society of South Africa and Others v. President of the Republic of South Africa and Others (20382/2015) [2018] ZAGPPHC 4; [2018] 2 All SA 806 (GP); 2018 (6) BCLR 695 (GP), Date of Judgment: 1 March 2018.

Southern African Litigation Centre v. The Minister of Justice and Constitutional Development and Others, Case No. 27740/2015, Date of Judgment: 24 June 2015.

\section{High Court of the Republic of Kenya}

(Decision reported at the National Council for Law Reporting of Kenya: http://kenyalaw.org/caselaw/cases/view/120130)

The Republic of Kenya v. Paul Kinuthia Gachoka and another, MISC

Criminal Application No. 60 of 2016, Date of Judgment: 8 March 2016.

\section{International Court of Justice}

(Decision is reported at the Homepage of the International Court of Justice: https://www.icj-cij.org/en/case/94)

Case Concerning the Land and Maritime Boundary Between Cameroon and Nigeria (Cameroon v. Nigeria: Equatorial Guinea Intervening), Judgement, ICJ Reports 2002, 303. Date of Judgment: 10 October 2002. 


\section{International Criminal Court}

(Decision is reported at the Homepage of the International Criminal Court:

https://www.icc-cpi.int/CaseInformationSheets/AlBashirEng.pdf)

Prosecutor v. Omar Hassan Ahmad al Bashir, Second Warrant of Arrest for

Omar Hassan Ahmad Al Bashir, ICC - 02/05-01/09-)5, P-T, Ch. I, Date of Judgment: 12 July 2010.

\section{Supreme Court of the Republic of Ghana}

(Decision reported at the Homepage of the Ghana Legal Information

Institute: https:/ghalii.org/gh/judgment/supreme-court/2016/20)

Republic v. High Court (Commercial Division) Accra, ex parte Attorney

General and NML Capital Ltd. Civil Motion No. 15/10/2013, Supreme

Court of Ghana, Date of Judgment: 20 June 2013.

\section{Supreme Court of the Republic of Nigeria}

(Decision reported at the Homepage of the International Centre for Nigerian

Law: https://nigerialii.org/ng/judgment/supreme-court/2000/17)

General Sani Abacha v. Chief Gani Fawehinmi, Appl. No.: S.C. 45/1997,

Date of Judgment: 28 April 2000.

\section{Supreme Court of the Republic of South Africa}

(Decision reported at the Homepage of the Southern African Legal

Information Institute: http://www.saflii.org/za/cases/ZASCA/2012/122.html)

Government of the Republic of Zimbabwe v. Fick, Appl. No.: 657/11,

ZASCA 122 (SCA), Date of Date of Judgment: 27 September 2012.

\section{Tribunal of the Southern African Development Community}

(Decisions reported at the Southern African Legal Information Institute:

http://www.saflii.org/sa/cases/SADCT/)

Barry L.T. Gondo \& Others v. The Republic of Zimbabwe, Appl. No.: (T)

05/2008, Date of Judgment: 09 December 2010.

Bookie Monica Kethusegile-Juru v. the Southern African Development

Community Parliamentary Forum, 2010, Appl. No.: SADCT 2, Date of Judgment: 5 February 2010.

Louis Karel Fick v. The Republic of Zimbabwe; Appl. No.: SADC(T)

01(2010), Date of Judgment: 16 July 2010.

Luke Munyandu Tembani v. Republic of Zimbabwe, Appl. No.: (SADC (T)

07/2008) [2009] SADCT 3, Date of Judgment: 14 August 2009.

Mike Campbell (PvT) Ltd. and 78 Others v. Republic of Zimbabwe, Appl.

No.: 2008 SADCT 2, Date of Judgment: 28 November 2008.

Tembani v. Republic of Zimbabwe, Appl. No.: (SADC (T) 07/2008) [2009]

SADCT 3, Date of Judgment: 14 August 2009. 
United Republic of Tanzania v. CIMEXPAN (Mauritius) Ltd., CIMEXPAN (Zanzibar) Ltd. and Ajaye Jogoo, Appl. No.: SADC (T(01/2009, Date of Judgment: 6 June 2010.

\section{United Kingdom Supreme Court}

(Decision reported at the Homepage of the United Kingdom Supreme Court: https://www.judiciary.uk/judgments/r-miller-v-secretary-of-state-for-exitingthe-european-union/)

Miller and another v Secretary of State for Exiting the European Union, [2017] UKSC 5, Date of Judgment: 24 January 2017. 


\section{Introduction}

After World War II as well as the Cold War, the political landscape of Africa changed fundamentally. In a long process, which lasted up to the mid 1990s, the remaining territories under colonial domination achieved independence. In order to promote peace, independence and development, African States started a close cooperation lasting until today. The cooperation effectively started out at regional level but was soon accompanied by developments at subregional level. Diverse structures emerged for this purpose and developed over time. Thus all regional and subregional structures started developing their own institutions and processes in order to ensure the implementation of the respective objectives.

The process of regional and subregional integration was linked to the post-war international order and the United Nations system more specifically. Thus the regional and subregional integration process within Africa served different objectives, such as the maintenance of peace and security, development and economic integration. However, with the end of colonization human rights and democratic participation played an increasing role in this process. This study will explore, how these two aspects emerged in terms of rules and institutions. It will also assess the working of related institutions in practice in order to assess the effectiveness of human rights protection and democratic participation in African regional and subregional integration. The protection of human rights and a functioning democracy - also at regional and sub-regional level - are closely interlinked. 
The dissertation in consequence aims to discuss whether and to what extent parliamentary and judicial structures exist at regional and sub-regional level. Furthermore, the thesis aims to answer the question whether and to what extent courts are authorized to decide on human rights-related issues and whether these judicial decisions are ultimately enforced at the national level. Furthermore, the paper wants to answer the question to what extent the different parliamentary structures have acquired competences with regard to legislative competences, among other things.

The answer to these questions is based on a comprehensive evaluation of the various court rulings and the communications of the African Commission. In addition, the various founding treaties and the protocols of the various institutions were included in the study. Besides that, a comprehensive evaluation of secondary legal scientific sources was carried out. Finally, internet sources such as newspapers were included in the dissertation, among other things to present the latest developments up to September 2018.

The dissertation is structured as follows: chapter 1 will lay the ground by exploring the international context by looking at the United Nations, its human rights agenda and its approach to regional integration. Chapter 2 deals with developments at the regional level, mainly the human rights institutions of the African Union (AU). The institutions that are analysed in depth are the African Court of Human and Peoples' Rights (later on transformed to the African Court of Justice and Human and Peoples' Rights), the Pan African Parliament as well as the African Commission of Human and Peoples' Rights. The protection of human rights as well as the level of popular participation on subregional level will be discussed in chapters 3 until 7, which will focus on regional economic communities in sub-Sahara Africa - particularly the Southern African Development Community (SADC), the East African Community (EAC), the Economic Community of Western Africa (ECOWAS) and the Common Market of Eastern and Southern Africa (COMESA). In conjunction with the protection of human rights, the dissertation, will involve the East African Court, the Tribunal of the Southern African Development Community, the Court of Justice of the Economic Community of Western Africa and the Court of Justice of the Common Market of Eastern and Southern Africa. With regard to the question of popular participation on subregional level the discussion includes several parliamentary structures such as the East African Legislative Assembly, the Southern African Development Community Parliamentary Forum and the Parliament of the Economic Community of Western Africa. The findings of the study will be summarized in a concluding chapter. 


\section{Chapter 1: \\ Developments towards regional integration in Africa}

\subsection{The establishment of the United Nations - a milestone for the international recognition of human rights}

Following the end of World War II, the international community was concerned with upholding peace worldwide. Consequently, several countries accepted that the principle of the rule of law, which before the end of the World War II was of national concern, had to be promoted on the international level. Thus, statesmen were in search of an internationally accepted concept leading to the restoration of peace and the effective protection of the rule of law.

The idea for the creation of an international body responsible for the protection of international peace and for upholding human rights can be traced back to the Atlantic Conference of 1941 where former US President Franklin D. Roosevelt and UK Prime Minister Winston Churchill declared, in Principle 6 of the Atlantic Charter, that 'after the final destruction of the Nazi tyranny, they hope to see established a peace which will afford to all nations the means of dwelling in safety within their 


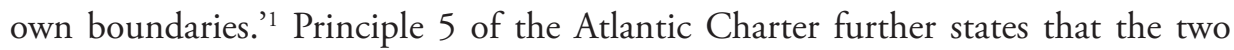
statesmen desired to 'bring about the fullest collaboration between all nations in the economic field with the object of securing for all, improved labor standards, economic advancement, and social security.' Consequently, following the end of the World War II, the organization of United Nations was established in 1945 through the adoption of the Charter of the United Nations (UN Charter). ${ }^{2}$

The adoption of the UN Charter was a milestone with regards to the history of international human rights. ${ }^{3}$ Art. 1(3) of the UN Charter states that the comprehensive human rights protection to all individuals forms part of the goals of the UN. Before the adoption of the UN Charter and also the Universal Declaration of Human Rights, only States were subjected to international law, while individuals did not have any such rights. ${ }^{4}$

The UN originally consisted of 51 members but over the course of time this number grew to 193 today. ${ }^{5}$ Regarding the African continent, Egypt, Ethiopia, Libya and the Union of South Africa joined the UN in 1945, following their independence. ${ }^{6}$ With the establishment of the UN Charter as well as the Universal Declaration of Human Rights, a human rights system on a global level was founded. ${ }^{7}$

Three years after the adoption of the UN Charter, the Universal Declaration of Human Rights was proclaimed enumerating the basic principles of international human rights standards, which were developed by the UN Commission on Human and Peoples Rights. In 1966, the International Covenant on Civil and Political Rights (ICCPR) was adopted, which next to the Universal Declaration forms part of the International Bill of Human Rights. ${ }^{8}$ Those steps were taken in order to prevent the potential abuse of individuals. ${ }^{?}$

Arts. 1, 55 and 56 of the UN Charter oblige members of the UN to cooperate with regards to human rights protection, stating that the Member States should take action in order to achieve the goals of the United Nations including 'univer-

1 J. A. Frowein, 'United Nations (UN)', in R. Wolfrum (ed), Max Planck Encyclopedia of Public International Law (2012), para 1.

2 For more historic background see: E. Posner, The Twilight of Human Rights Law, Chp. 1 (2014).

3 A.O. Adede, 'International Human Rights Law: Lessons for Treaty-Making and Implementation',3 African Yearbook of International Law (1995) 1, 99, 100; see more detailed: T. Weiss, S. Daws, (eds) The Oxford Handbook on the United Nations, 2nd ed. (2018).

4 T. Buergenthal, 'Human Rights' in R. Wolfrum (ed), Max Planck Encyclopedia of Public International Law (2007), para 3.

5 Frowein (2012), para 2.

6 F. Viljoen, International Human Rights Law in Africa (2007), 48.

7 D. Shelton, Regional Protection of Human Rights (2008), 15; see more details in: H. Charleswoth, 'Universal Declaration of Human Rights (1948)' in R. Wolfrum (ed), Max Planck Encyclopedia of Public International Law (2007); J Morsink, The Universal Declaration of Human Rights, Origins, Drafting and Intent, (1999).

8 A. Kaczorowska, Public International Law, 5th ed. (2015), 515.

9 I. De Jesus Butler, 'Securing human rights in the face of international integration', 60 International \& Comparative Law Quarterly 1 (2011), 125. 
sal respect for, and observance of, human rights and fundamental freedoms for all without distinction as to race, sex, language or religion'. ${ }^{10}$ These provisions, even though of vague character had, compelled the UN Member States to accept some obligations with regard to human rights protection, leading to a deeper cooperation. Since most provisions of the UN Charter were vague, the UN Commission on $\mathrm{Hu}$ man and Peoples' Rights had to define the specific human rights in order to provide a common standard on the international level. ${ }^{11}$

Similarly, to the above-listed articles of the UN Charter, the Preamble to the Universal Declaration of Human Rights of 1948 reiterates and further specifies the obligation of co-operation with respect to human rights. ${ }^{12}$ The Universal Declaration of Human Rights was supposed to be a non-binding resolution stipulating a common understanding of human rights. However, today, the Declaration is accepted by most States, together with the UN Charter, as defining human rights obligations. ${ }^{13}$

Taking into consideration the various resolutions of the UN General Assembly it is evident that

[a]ll Member States have the obligation to promote and protect human rights and fundamental freedoms as stated in the Charter of the United Nations and elaborated in the Universal Declaration of Human Rights, the International Covenants on Human Rights and other applicable human rights instruments. ${ }^{14}$

International human rights nowadays have evolved into two additional levels beyond the domestic level, which regularly forms the core of the protection of human rights. The first tier is formed by subregional organizations, which connect a number of States on a regionally restricted basis. The second layer is represented by the regional level, which comprises States within a particular continent. ${ }^{15}$

In order to achieve its goals with regard to the African continent, the UN provides for several agencies which primarily focus on peace and development of the African continent. One of these institutions is the Economic Commission for African which is made up of 54 Member States. The Economic Commission is mandated to operate at regional and subregional level in order to promote the economic and social development of its Member States while promoting international cooperation. ${ }^{16}$ Besides that, the UN established several peace-keeping operations within the whole continent, such as the United Nations Mission for the Referendum in

\footnotetext{
10 See: Art. 1(3) of the 1945 Charter of the United Nations.

11 Kaczorowska (2015), 515.

12 R. Wolfrum, 'Sources of International Law', in R. Wolfrum (ed), Max Planck Encyclopedia of Public International Law (2006), para 61.

13 Buergenthal (2007), para. 9; see more detailed: P. Alston, The United Nations and human rights: a critical appraisal, 2nd. ed. (2018).

14 De Jesus Butler (2011), 144.

15 Viljoen (2007), 9; for more details see: S. Murphy, Principles of International Law, 3rd ed. (2018).

16 United Nations Economic Commission for Africa - Overview; available at: https://www.uneca. org/pages/overview, (last visited: 14 August 2020).
} 
Western Sahara (MINURSO), the African Union-United Nations Mission in Darfur (UNAMID) and the United Nations Support Office in Somalia (UNSOS).${ }^{17}$ In addition to the UN established several offices in Nairobi, Kenya, such as the United Nations Office, being the UN Headquarter in Africa as well as the Environment Programme (UNEP) and the UN Human Settlements Programme (UN-HABITAT). ${ }^{18}$

\subsection{The United Nations and regional integration}

The United Nations is the main international institution competent to fulfill tasks of safeguarding peace and security, protecting human rights, and encouraging economic cooperation worldwide. Therefore, besides the preservation of peace, the protection of human rights ranks among the main objectives of the UN. Consequently, the UN Charter was enacted, which provides for several provisions aiming to achieve the objectives of the UN.

While the United Nations is designed as a universal system, the Charter nevertheless envisages regional cooperation to some degree. Chapter VIII of the UN Charter sets out several requirements concerning the establishment of regional agreements. Some of these regional arrangements can be based on the Charters' rules on self-defence as enshrined in Art. 51, as is true, for instance, for the North Atlantic Treaty Organization (NATO) which is considered the most powerful international body regarding the protection of global security. ${ }^{19}$ However, the main basis for regional cooperation is to be found in Chapter VIII of the Charter. The Chapter determines the relations between the United Nations and regional institutions in matters of peacekeeping and security. ${ }^{20}$

Art. 52 of the UN Charter states that:

Nothing in the present Charter precludes the existence of regional arrangements or agencies for dealing with such matters relating to the international peace and security as are appropriate for regional action provided that such arrangements or agencies and their activities are consistent with the Purposes and Principles of the United Nations.

The requirement of the 'maintenance of peace and security' may, consequently, hold that only such regional agreements which provide for peaceful dispute settlement structures regarding international peace and security may fall under Art. 52. How-

17 United Nations - Africa; available at: https://www.un.org/en/sections/where-we-work/africa/ index.html, (last visited: 14 August 2020).

18 Ibid.

19 Y. Oke, 'Substitute for the United Nations? Extending frontiers of the North Atlantic Treaty Organisation and Implications for African Unity', 21 Afr J Int'l \& Comp L 1 (2013) 120; for more details see: T. Marauhn, 'North Atlantic Treaty Organization', in R. Wolfrum (ed), Max Planck Encyclopedia of Public International Law (2007).

20 L. Boisson de Chazournes, Interactions between Regional and Universal Organisations (2017), 142. 
ever, the International Court of Justice (ICJ), in the Case Concerning the Land and Maritime Boundary between Cameroon and Nigeria stated that the Lake Chad Basin Commission was to be characterized as a regional organization despite lack of such dispute settlement structures. ${ }^{21}$

The intervention of the Economic Community of West African States (ECOWAS $^{22}$ in Liberia in 1993, which was preliminary based on the 1981 Protocol on Mutual Assistance in Defense of ECOWAS, shows the impact of a regional cooperation regarding peacekeeping purposes. ${ }^{23}$

Outside the system of the United Nations, regional integration is promoted by the WTO. Art. XXIV of the General Agreement on Tariffs and Trade (GATT) (as further explained in Chapter 3) allows for members of the WTO to engage in regional economic integration through the establishment of regional trade agreements. Besides the General Agreement on Tariffs and Trade, Art. 5 of the General Agreement on Tariffs and Services (GATS) allows regional integration stating that any party to the GATS Agreement shall be eligible to become party of an agreement liberalizing trade if such agreement has substantial sectoral coverage and provides for the absence or elimination of discrimination.

\subsection{The concept of Pan-Africanism as an example of regionalism}

A starting point to analyze the process of regional integration and the protection human rights in Africa of non-national level is the period of African nationalism and the emergence of pan-Africanism. ${ }^{24}$

At its core, the idea of Pan-Africanism is the internationalization of African liberation philosophy, which seeks to unify and empower people of African descent all over the world to demand and attain freedom, equality, and justice from domestic and global forces of white domination, and to maximize their human potential. ${ }^{25}$

21 Case Concerning the Land and Maritime Boundary Between Cameroon and Nigeria (Cameroon v. Nigeria: Equatorial Guinea Intervening), Judgment, ICJ Reports 2002, 303.

22 The intervention of ECOWAS took place during the first Civil War in Liberia. ECOWAS states decided to set up an Economic Community Monitoring Group (ECOMOG) under the leadership of Nigeria. The objective of ECOMOG was to impose a cease-fire, to help Liberians to establish an interim government until elections were held, stop the killing of civilians and to ensure the evacuation of foreign nationals (for an overview see: 'ECOWAS and the Subregional Peacekeeping in Liberia', The Journal of Humanitarian Assistance (25 September 1995), available at http://sites.tufts.edu/jha/archives/66 (last visited: 7 September 2018).

23 Boisson de Chazournes (2017), 149.

24 EOA El-Obaid \& K. Appiagyei-Atua, 'Human Rights in Africa - A New Perspective on Linking the Past to Present', 41 McGill Law Journal (1996) 1, 819, 823.

25 J. I. Levitt, 'Beyond Borders: Martin Luther King, Jr., Africa, and Pan Africanism, A Festschrift in Honour of Professor Henry J. Richardson III', 31 Temp Int'l \& Comp LJ (2017), 301, 303. 
The beginning of the movement can be traced back to Edward Wilmot Blyden, who was first settled in Liberia, which became independent in 1847 . He started a movement - under the example of some leaders in Diaspora, such as inter alia Marchus Garveyy, WEB Du Bois and George Padmore, to create a 'common voice' for all African ${ }^{26}$ and initiated campaigns promoting the unity of West Africa.

After the end of World War II, due to the struggle of decolonization, Africans focused on the promotion of nationalism within the whole continent. This phase inter alia included the following goals: political independence from the colonial states, cooperation among African States as well as the creation of a federation with the creation of subregional entities. The continent's independent states were focused on founding regional and ideological groups. Such ideas were triggered by the Pan-African Conference. ${ }^{27}$

During the 1945 Pan-African Congress in Manchester ${ }^{28}$ it was declared: ' $[w] \mathrm{e}$ are determined to be free. We want education. We want the right to earn a right to express our thoughts and emotions, to adopt and create forms of beauty. We will fight every way we can for freedom, democracy and social betterment. ${ }^{29}$

One of those regional arrangements established was the Organization of African Unity (OAU), which was later transformed into the African Union (AU).

Following the establishment of OAU in 1963, other subregional economic communities were set up, such as the East Africa Community (1967), the Economic Community of West African States (ECOWAS, 1975) and the Southern African Development Coordination Conference (SADCC, 1980). However, the main objective of the subregional agreements was not the protection of human rights as such, but the economic development and integration of the states involved. ${ }^{30}$ Thus, apart from the developments at a regional level, which were influenced by the thought of Pan-Africanism, the regional integration also took place at a subregional level. These developments constitute an exception to the universal idea of Pan-Africanism.

26 Viljoen (2007), 158.

27 P. M. Munya, 'The Organisation of African Unity and Its Role in Regional Conflict Resolution and Dispute Settlement: A Critical Evaluation' 19, BC Third World LJ (1998) 537, 541.

28 The pan-African conference consisted of a number of meetings that intended to discuss issues regarding the African continent resulting from the European colonization. The Congress gained a reputation as a peacemaker for decolonization in Africa. It set the ground for the Pan-African concept and demanded to end colonialism and racial discrimination; (see: 'A history of PanAfricanism', 326 New Internationalist (August 2000), available at: https://newint.org/ features/2000/08/05/simply (last visited: 7 September 2018).

29 C. Heyns, 'A struggle approach" to human rights', in C. Heyns \& K. Stefiszyn (eds), Human Rights, Peace and Justice in Africa: A Reader (2006), 20.

30 L. N. Murungi \& J. Galinetti, 'The Role of Sub-Regional Courts in the African Human Rights System', 7 International Journal on Human Rights (2010) 13, 119. 


\section{Chapter 2: \\ Integration at regional level - the African Union (AU)}

On the African continent, the developments towards the establishment of a regional concept started with the creation of the Organization of African Unity. Subsequently, several subregional developments took place within several areas of Africa simultaneously. As far as the whole African continent is concerned, the African Union (AU) has been established as the successor of the Organization of African Unity (OAU). The African Union is concerned with inter alia promotion of the rule of law and human rights as well as popular participation. 


\subsection{Historical background: from the Organization of African Unity (OAU) to the African Union (AU)}

The establishment of the African Union is the outcome of a long-standing process which began with the adoption of the Charter of the Organization of African Unity and the creation of the OAU in $1963,{ }^{31}$ enhancing regional integration within the post-colonial African continent. However, the discussion on the establishment of a Pan-African bloc already commenced some years before.

In 1961, the Prime Ministers of Nigeria and Sierra Leona, as well as the former President of Liberia, William Tubman, decided to hold a conference, composed of the leaders of all independent African States, with the aim to focus on inter-African co-operation. Liberia, which was the oldest out of the three States offered to become the host of the first negotiations.

The group of African independent States also included a group of African States, which has been known as the Casablanca bloc. ${ }^{32}$ The bloc was formed by the United Arab Republic, Ghana, Guinea, Mali and Morocco. ${ }^{33}$ The African Charter of Casablanca establishing the bloc was signed at a conference that took place in Casablanca (Morocco) at the beginning of January 1961..$^{34}$

The Charter inter alia determined that other independent African countries should become connected with the Member States of the Casablanca bloc. Additionally, the Charter contains the provision for the set-up of a 'supra-national African consultative assembly' once the circumstances within the continent would facilitate such an institution. ${ }^{35}$

The Casablanca bloc suggested the creation of an immediate union of the independent States all over the African continent. This scenario would have led to a single Pan-African government with separate but integrated political, economic and military systems. ${ }^{36}$

31 Murungi \& Gallinetti (2010), 119.

32 The so-called Casablanca Group was an informal union of some African States that shared the vision of Pan-Africanism at that moment. Thus, only unity within the African continent would be able to cast out colonization and increase economic development. Also, they believed that broadcast of several powers to a supranational organisation would achieve those goals. However, the Group was finally unsuccessful since most of the African leaders did not give support to that idea; (see: P. Englebert \& K. C. Dunn, Inside African Politics (2013), 320 - 321).

33 T. O. Elias, 'The Charter of the Organisation of African Unity', 59 American Journal of International Law 2 (1965), 243.

34 AMR Ramolefe \& AJGM Sanders, 'The Structural Pattern of African Regionalism' 4 Comparative and International Law Journal of Southern Africa, 2 (1972) 155, 160 et seq.

35 Ibid.

36 C. Heyns, E. Baimu \& M. Killander, 'The African Union', 46 German YB Int'l L (2003), 254. 
The other bloc made up of the Brazzaville ${ }^{37}$ and the Monrovia Group, ${ }^{38}$ was in support of the so-called gradualist approach. The first group argued for an immediate unification beginning with regional economic integration, which would lead to further integration developments in the future. However, the Brazzaville Group argued that the unification would first commence with regional and cultural cooperation. ${ }^{39}$

The first conference of the leaders of the independent African States on the establishment of a Pan-African Organization was held in Monrovia, the capital of Liberia in May 1961, where 22 out of 27 African governments from independent States participated - the representatives of the Casablanca bloc did not.

The initial ideas of the various groups, which had emerged between 1960 and 1961 either made provisions for the set-up of a 'Federation of African States' or the 'United States of Africa'. The outcome of the numerous negotiations was thus a compromise between the different approaches of the groups. ${ }^{40}$

During the second conference of African Heads of State and Government held in 1962 in Lagos, the first Draft Protocol was issued. Again, the Casablanca bloc did not attend the negotiations, stating that the invitation was not sent to the Provisional Government of Algeria, which was in exile and thus they were not able to participate as an organization of fully independent States since Algeria was not yet fully independent from France. The Council of Ministers prepared the third meeting agreeing on a text based on the Lagos Charter, the Casablanca Charter and an Ethiopian Draft Charter in order to create the Charter of the OAU.

After the negotiation about the next venue for the third conference, the Casablanca bloc finally stated that the capital of Ethiopia, Addis Ababa would be an acceptable location. The OAU Charter was finally adopted in May 1963 during the Conference in Addis Ababa. ${ }^{41}$

37 The Brazzaville Group mainly comprised of former French colonies: Central African Republic, Cameroon, Ivory Coast, People's Republic of Congo, Dahomey, Mauritania, Gabon, Upper Volta (the present-day Burkina Faso=, Senegal, Niger, Chad and Madagascar. This group stood for a gradualist approach to the concept of African Unity, starting with regional economic and cultural co-operation. It signed its Brazzaville Charter on 19 December 1960 and became operational on 12 September 1961 (see in more detail: Viljoen (2007), 160).

38 The Monrovia Group consisted of Nigeria, Sierra Leone, Liberia, Togo, Ivory Coast, Cameroon, Senegal, Dahomey, Malagasy Republic, Chad, Upper Volta, Niger, Peoples' Republic of Congo, Gabon, Central African Republic, Ethiopia, Somalia and Tunisia. The Monrovia Group was officially formed from 8-12 May 1961. This group preferred a gradualist approach, like the Brazzaville Group, in order to achieve African Unity; (see in more detail: P. Englebert \& K. C. Dunn (2013), 320-321.)

39 Viljoen, (2007), 160.

40 G. Manelisi, F. Kornegay \& S. P. Rule, African Union and Pan-African Parliament: Working Papers, Africa Institute of Pretoria (2000), 2.

41 Elias (1965), 245. 
The Charter of the OAU sets out the objectives of the Organization of African Unity. One of the OAU's main objectives was to guarantee the decolonization of the whole African continent. Thus, as a consequence, a platform was supposed to be established in order to push for the liberation of the whole continent.

Further, the Union was supposed to create unity among the African States that were newly independent. Moreover, the OAU was supposed to monitor the internal affairs of the decolonized African countries. ${ }^{42}$ Therefore, because of the experience of colonialism, the OAU States aimed to defend 'their sovereignty, their territorial integrity and independence. ${ }^{33}$ The reference to treaties of the United Nations marks the adherence of the Member States to the treaties and indicates that Heads of Government were aware of the principles of the UN Charter from the beginning. ${ }^{44}$

Art. 2 of the OAU Charter further declares that States should collaborate in a range of different fields such as political and diplomatic cooperation, educational and cultural cooperation as well as the fields of defense and security. However, the competencies of the OAU in these latter fields remained defensive in nature. ${ }^{45}$

Art. 2 (1)(b) further promotes the achievement of better living conditions for the people of Africa. Additionally, Art. 2 (1)(a) encourages unity and solidarity of the African States whereas Art. 2 (1)(c) promotes the defense of sovereignty, territorial integrity and their independence and to ensure the eradication of all forms of colonialism.

Regarding the protection and promotion of human rights, the preamble of the OAU Charter again referred to the United Nations Charter as well as the Universal Declaration of Human Rights, stating that international documents would provide for a 'solid foundation for peaceful and positive co-operation among States. ${ }^{36} \cdot{ }^{47} \mathrm{In}$ order to achieve human rights protection e.g. Malawi incorporated the Universal Declaration in its independence constitution.

Taking into consideration the principle of 'non-interference', the OAU did not provide for any effective protection against human rights violations within its Member States. ${ }^{48}$ However, the OAU pushed towards the decolonization of African

42 M. Cowling, 'African Union - An Evaluation, The Notes and Comments', 27 S Afr YB Int'l L (2002), 194.

43 P. Alston \& R. Goodman, International Human Rights - The Successor to International Human Rights in Context: Law, Politics and Morals (2013), 1026.

44 Ibid.

45 Ibid.

46 Elias (1965), 246

47 M. Hansungule, 'The African Charter on Human and Peoples Rights: a critical review', 8 African Yearbook of International Law (2000), 271; see also: A. MB Mangu, 'What Future of Human and Peoples' Rights under the African Union, New Partnership for Africa's Development, African Peer-Review Mechanism and the African Court', 29 S Afr YB Int'l L 1 (2004), 136, 138.

48 Hansungule (2000), 271. 
countries, which by the end led to a stronger recognition of human rights. Besides that, the striving for decolonization would ultimately lead to more peace within the region which in turn was in accordance with Art. 52 of the UN Charter. ${ }^{49}$

Still, the recognition of human rights and therewith the promotion of the rule of law was not one of the main objectives of the former Organization of African Unity.

After some years it became obvious that many States were hesitant in transmitting some parts of their recently attained sovereignty. Thus, regarding the violation of human rights, the OAU has, 'turned a blind eye'. ${ }^{50}$ This, in addition to the OAU's failure to resolve many civil wars within the African continent and the non-interference in internal affairs of the countries finally lead to an African-wide dissatisfaction with the OAU. ${ }^{51}$

Due to the fact that most States were focusing on their sovereignty, the OAU did not introduce mechanisms to enforce its decisions and resolutions. Consequently, the OAU did not have much impact on peacekeeping and human rights protection. ${ }^{52}$ After the end of the Cold War and the liberation of most African countries, the winds of political change also swept through the African continent. Thus, in 1990, the OAU adopted the Declaration on Political and Socio-Economic Situation in Africa, which noted that the era of political liberation was coming to an end and that more focus should be given to economic integration. Moreover, the OAU adopted many human rights related instruments, such as the Protocol to the African Charter on Human and Peoples' Rights on the Rights of Women and the African Charter on the Rights of Welfare of the Children as well as the Protocol on the Establishment of the African Court on Human and Peoples' Rights, all of which will be discussed in chapter 2 .

Following the end of both the Cold War internationally and of the apartheid regime in South Africa, the OAU was in need of transformation. Multi-party democratic elections were held all over the continent for instance in Benin and Zambia. Consequently, constitutions were drafted, and political and civil rights were restored. ${ }^{53}$ The promotion of human rights has, therefore, gained importance on the African continent. However, the OAU did not provide for a meaningful and effective framework to implement these principles.

In 1999, the fourth extraordinary Summit of the OAU was convened in order to discuss 'ways and means of making the OAU effective so as to keep pace with the political and economic developments taking place in the world. ${ }^{54}$ After an in-

49 Viljoen (2007), 163.

50 K.O Kufour, 'The Collapse of the Organisation of African Unity: lessons from economics and history', 49 Journal of African Law 2 (2005), 132, 133 et seq.

51 Ibid.

52 Heyns et al (2003), 258.

53 Viljoen (2007), 169.

54 See: Decision on the Convening of an Extraordinary Session of the OAU Assembly of Heads of State and Government in accordance with Art. 33(5) of its Rules of Procedure; OAU Doc. AHG/Dec.1 (XXVI), para. 12. 
tensive debate, the members of the Assembly concluded that the 'OAU needs to be revitalized in order to be able to play a more active role and continue to be relevant to the needs of [the] peoples and responsive to the demands of the prevailing circumstances. ${ }^{55}$

In 2002, the chairperson Thabo Mbeki, former President of the Republic of South Africa, finally dissolved the OAU. However, African States were still in support of the idea of an African-wide regional economic community. Thus, during the $35^{\text {th }}$ Ordinary Session of the Summit of OAU in Algier in 1999, the Heads of States and Government examined carefully up to date achievements of the OAU. ${ }^{56}$ They concluded that the OAU has 'an irreplaceable role in the affirmation of political identity and the realization of the unity of the continent. ${ }^{\prime 57}$ Therefore, only a couple of months after the Summit of Algier, the former President of Liberia, Muammar Gaddafi, asked the Heads of State and Government of the OAU to hold an Extraordinary Session in order to discuss '[...] extensively on ways and means of strengthening our continental organisation to make it more effective so as to keep pace with political, economic and social developments taking place within and outside the continent.' 58

After negotiations between the governments were concluded, the Heads of State and Government decided to 'establish the African Union, in conformity with the ultimate objectives of the Charter of our Continental Organisation and the provisions of the Treaty establishing the African Economic Community. ${ }^{59}$ In accordance to such provisions, the legal unit of the OAU elaborated a draft Constitutive Act. Finally, twenty-five Heads of State and Government adopted the Constitutive Act on 11 July $2000 .^{60}$

In accordance to the Act of the African Union, the OAU was to be replaced by the AU after a one-year transition period. ${ }^{61}$ As a consequence of the decision agreed upon during the $37^{\text {th }}$ OAU Summit held in Lusaka, Zambia, the transition period started in July 2001. The African Union was finally established in Durban, South Africa on 9 July $2002 .^{62}$

\footnotetext{
55 See: Sirte Declaration, (9 September 1999), OAU Doc. EAHG/Draft/Decl. (IV) Rev. 1 [Sirte Declaration].

56 Mangu (2004), 141.

57 See: Sirte Declaration.

58 Ibid.

59 V. O. Nmehielle, 'The African Union and African Renaissance: A New Era for Human Rights Protection in African?', 7 Singapore Journal of International and Comparative Law (2003), 412, 415 et seq.

60 Ibid., 416.

61 See: Art. 33 of the 2001 Constitutive Act of the African Union.

62 Heyns et al (2003), 259.
} 


\subsection{Purposes and achievements of the African Union (AU) - winds of change?}

The Constitutive Act of the African Union indicates new objectives of the African Union. These objectives include the promotion of peace, security and stability all over the continent. They also contain obligations to promote democratic principles, participation of citizens and good governance. In addition, in these objectives, the $\mathrm{AU}$ also included the protection and promotion of human and peoples' rights. Furthermore, the Union aims to achieve 'greater unity and solidarity between the African countries and the peoples of Africa. ${ }^{63}$ The AU Constitutive Act commands a 'right of the Union to intervene in a Member State pursuant to a decision of the Assembly in respect of grave circumstances, namely war crimes, genocide and crimes against humanity. ${ }^{34}$ African leaders have up until now rarely made use of their right of intervention, which in general is fully dependent on the political will of the leaders and the provision of armed forces and financial resources. ${ }^{65}$

Since its inauguration, the African Union achieved some significant developments with regard to the African Union Constitutive Act: during its first Summit in July 2002, the AU Assembly adopted the Protocol to the Act on the Peace and Security Council (PSC) that came into force in $2004{ }^{66}$ The Protocol was supposed to replace the mostly ineffective Mechanism for Conflict Prevention, Management and Resolution in Africa ${ }^{67}$ The PSC is a 'standing decision-making organ for the prevention, management and resolution of conflicts' and provides for four institutions, namely the Panel of the Wise, the Continental Early Warning System, the African Standby Force and the Special Fund. ${ }^{68}$ The PSC is supposed to oppose unconstitutional changes of governments and may also use sanctions in order to achieve its goals. This movement clearly highlights that the African Union was introducing the adherence to democratic principles, such as free and fair elections. ${ }^{69}$

63 See: Art. 3 of the 2000 Constitutive Act of the African Union; see also: Heyns et al (2003), 260.

64 See: Art. 4(h) of the 2000 Constitutive Act of the African Union.

65 Mangu (2004), 142.

66 S. Vandeginste, 'The African Union, Constitutionalism and Power-Sharing', 57 Journal of African Law 1 (2013), 3.

67 During the 1990 OAU Summit, African leaders took into consideration that the prevalence of conflicts on the continent had seriously hampered their individual and collective efforts at political and economic development and pledged to work together to reduce the scourge of conflicts in Africa. Hence, at the OAU summit of 1992, the OAU Secretary-General Salim Ahmed Salim submitted a report 'Report of the Secretary-General on Conflicts in Africa: Proposals for an OAU Mechanism for Conflict Prevention, Management and Resolution. After several recommendations and discussions, the Mechanism was presented to the OAU summit in Cairo 1993 and subsequently adopted by most of all OAU Member States; (see: M. Muyangwa \& M. A. Vogt, An Assessment of the OAU Mechanism for Conflict Prevention, Management and Resolution, 1993-2000 (2002), available at: https://www.ipinst.org/wp-content/uploads/publications/ oau_conflict_1993_2000.pdf (last visited: 7 September 2018).

69 See: Sirte Declaration. 
Additionally, the First Extraordinary Session of the AU Assembly adopted several amendments ${ }^{70}$ of different nature with regard to the Constitutive Act. ${ }^{71}$ One of the greatest achievements of the young African Union was the submission of sufficient instruments of ratification to the Protocol of the African Court of Human and Peoples' Rights during the AU Summit in Maputo, Mozambique in 2003. ${ }^{72}$

\subsection{Organs of the African Union (AU)}

The African Union provides for several institutions and orders to ensure the effective implementation of the above-explained purposes.

The Constitutive Act of the African Union created the following organs: The Assembly, the Executive Council, the Pan-African Parliament, the African Court of Justice, the African Commission on Human and Peoples' Rights, the Permanent Representatives Committee, the Specialized Technical Committees, the Economic, Social and Cultural Council, and financial institutions such as the African Central Bank and the Investment Bank and an African Monetary Fund.

The Assembly of Heads of State and Government is regarded as the supreme Organ of the African Union and is mandated to meet at least once a year, as per Art. 6(2) of the Constitutive Act. Art. 7(1) of the Act requires at least a two-thirds majority within the Assembly in order to reach decisions. However, ideally the article stipulates decision-making by consensus within the Assembly. ${ }^{73}$ In general, the Assembly is mandated to determine the common policies of the AU and to oversee the general monitoring and implementation of such policies, according to Art. 9. Further, the Assembly has the responsibility to adopt the annual budget. ${ }^{74}$ Moreover, Art. 8 provides that the Assembly shall adopt its own Rules of Procedure.

The Executive Council is composed of the Ministers of Foreign Affairs of the respective Member State, as per Art. 10(1). The Executive Council is mandated to coordinate areas of common interest - covering topics such as foreign trade,

70 The main amendments with regard to the Constitutive Act where inter alia the addition of three new objectives to ensure a more effective participation of women in decision-making, development and promotion of common policies and encouraging participation of African Diaspora. Furthermore, the language Kiswahili was included as an official language of the Union. Additionally, an article became implemented which provided for the Peace and Security Council (PSC) (see: Protocol on the Amendments to the Constitutive Act of the African Union (11 July 2003), available at: https://au.int/en/treaties/protocol-amendments-constitutive-act-african-union, (last visited: 9 September 2018).

71 Heyns et al (2003), 258.

72 Decision on the Protocol of the Court of Justice of the African Union (2004), AU. Doc. Assembly/AU/Dec.25 (II), para. 2; see also: Heyns et al (2003) 261.

73 Cowling (2002), 200.

74 See: Art. 9(1)(f) of the 2001 Constitutive Act of the African Union. 
food and agriculture, environmental protection, and education. In accordance with Art. 11(1), the Executive Council - similar to the Assembly shall issue its decisions by consensus or by a two-thirds majority.

The Specialized Technical Committees that are established under Art. 14 of the Constitutive Act are responsible for the Executive Council, in accordance with Art. 15. Meetings on the ministerial and expert level every two years carry out the functions of the fourteen distinctive Committees. The AU, however, decided that the Committees on Gender and Women Empowerment, Finance, Monetary Affairs, Economic Planning and Integration, Defence, Safety and Security shall meet once a year. ${ }^{75}$

Besides the Specialized Committees, the Permanent Representatives Committee conducts the day-to-day business of the African Union on behalf of the Assembly and the Executive Council as per Art. 21(2). It reports to the Executive Council on regular basis, prepares the work of the Council and acts on its instructions.

Moreover, the Constitutive Act provides the foundation for the establishment of the African-Parliament and the African Court of Justice (ACJ).

The Pan African Parliament - under the provisions of Art. 17, is set up in order to ensure full participation of the peoples within the African continent in matters such as development and integration of the continent.

In order to ensure the establishment of the African Court of Justice, in 2003 the Assembly adopted the Protocol on the Court of Justice of the African Court. ${ }^{76}$ Art. 60 of the Protocol on the African Court of Justice states that the Protocol would enter into force one month after its fifteenth ratification. In 2008, eventually, the fifteenth ratification instrument was submitted by Algeria. However, the African Union never acknowledged the entry into force of the Protocol. ${ }^{77}$ Although the Protocol did not come into force, the internal structure of the Court of Justice will be briefly presented.

The ACJ is entitled jurisdiction over

all disputes and application relating to: the interpretation of its founding protocol; the interpretation, application or validity framework of the AU; any question of international law; all acts, decisions, regulations and directives of the organs of the AU; all matters specifically provided for in agreements that State parties conclude among themselves or with the AU and which confer jurisdiction on the

75 See: Decision on the Specialized Technical Committees (2011), Assembly/AU/Dec.365 (XVII).

76 M. Ssenyonjo \& S. Nakitto, 'The African Court of Justice and Human and Peoples' Rights "International Criminal Law Section": Promoting Impunity for African Union Heads of State and Senior State Officials?', 16 International Criminal Law Review 1 (2016), 71, 72.

77 G. J. Naldi \& K. D. Magliveras, 'The African Court of Justice and Human Rights: A Judicial Curate's Egg', 9 Int'l Org L Rev 2 (2012), 383, 386. 
court, the existence of any fact which, if established would constitute a breach of an obligation owed to a State party or the AU; and the nature or extent of the reparation to be made for the breach of an obligation. ${ }^{78}$

Every State party to the Constitutive Treaty of the AU and organs of the African Union (such as the AU Assembly, the Pan-African Parliament and others being authorized by the Assembly), is enabled to bring a claim before the African Court of Justice. ${ }^{79}$

In addition, according to Art. 19(1)(c) of the Protocol of the African Court of Justice individual staff members of the Commission are allowed to submit a claim to the African Court of Justice if labor-related issues arise. ${ }^{80}$ Taking into consideration the consent of the involved State, the AU Assembly is entitled to determine conditions under which 'third parties' are allowed to submit cases. Regional Economic Communities (RECs) are solely entitled to receive advisory opinions of the Court, Art. 44(1) of the Protocol of the Court of Justice of the African Union. Anyway, it is likely that the regional economic communities can claim before the Court as a third party under certain conditions. ${ }^{81}$

Regardless of the above uncertainty, the Court is able to give advisory opinions to the major organs of the AU, such as the Assembly, the Peace and Security Council the Executive Council and the financial institutions within the AU. Furthermore, regional economic communities have the possibility to request advisory opinions. ${ }^{82}$

The Constitutive Act itself did not provide much information regarding the nature of the Court. In the Constitutive Act, it was provided that a Protocol should outline more details e.g. on the structure and composition of the Court.

The African Court of Justice was established to resolve inter-African disputes in an independent and objective way. ${ }^{83}$ Since the mandate of the Court is of broad nature it covers also legal matters relating to the AEC Treaty and the AEC law, whose function within the AU structure will be explained later. ${ }^{84}$ This might even include issues like tariffs ${ }^{85}$, an issue of quite some importance, as African countries so far have been hesitant to make use of the WTO dispute settlement system. ${ }^{86}$ When the

78 See: Art. 19 of the Protocol of the Court of Justice of the African Union.

79 F. Viljoen \& E. Baimu, 'Courts for Africa: Considering the Co-Existence of the African Court on Human and Peoples' Rights and the African Court of Justice', 22 Neth Q Hum Rts 2 (2004), 241, 251.

80 Ndulo (2008), 196.

81 Viljoen \& Baimu (2004), 251.

82 See: Art. 18(2) of the 2000 Constitutive Act of the African Union.

83 Naldi \& Magliveras (2012), 385.

84 R. F. Oppong, 'The AU; AEC and regional economic communities', in Legal Aspects of Economic Integration in Africa (2011), 8.

85 V. Mosoti, 'Africa in the First Decade of WTO Dispute Settlement', 12 African Yearbook of International Law (2004), 67, 70.

86 E. Kessie \& K. Addo, African Countries and the WTO Negotiations on the Dispute Settlement Understanding (2007), 1. 
Protocol was adopted in 2003, it became apparent that the Court's mandate was to interpret any legal matters that arise due to the implementation and application of the AU Constitutive Act. ${ }^{87}$ Art. 26 of the Constitutive Act furthermore stipulates that until the establishment of the Court, the assembly would handle the tasks of the Court.

Next to the African Court of Justice the African Court on Human and Peoples' Rights was set up by virtue of Art. 1 of the Protocol to the African Charter on Human and Peoples' Rights on the Establishment of an African Court on Human and Peoples' Rights, which was adopted by the Member States of the Organization of African Unity in $1998 .{ }^{88}$ The Court has jurisdiction over all cases and disputes involving the interpretation of the 1986 African Charter of Human and Peoples' Rights.

Besides the African Court on Human and Peoples' Rights, the African Commission on Human and Peoples' Rights is mandated to oversee and interpret the African Charter on Human and Peoples' Rights by using a procedure of Communications, in accordance with Art. 45(3) of the African Charter. The African Commission is not mentioned within the AU Constitutive Act and thus is not an official organ of the AU.

Furthermore, Art. 19 of the AU Constitutive Act provides for three specific financial organs to be created: the African Central Bank (ACB), the African Investment Bank (AIB) and the African Monetary Fund (AMF). The role of these institutions is to implement the economic integration called for in the 1991 Treaty Establishing the African Economic Community (Abuja Treaty). The African Monetary Fund is purposed to create a single African currency, whereas the African Investment Bank aims to foster economic growth and to accelerate economic integration. In turn, the African Monetary Fund is deemed to facilitate the integration of African economies while ensuring the elimination of trade restrictions as well as the provision of greater monetary integration.

Finally, the Peace and Security Council (PSC) is the standing organ of the African Union in order to ensure the prevention, management and resolution of conflicts. The organ is a key element of the African Peace and Security Architecture (APSA). APSA is the 'umbrella' term for the main mechanism of the African Union promoting peace, security and stability within the continent. The PSC provides for an early warning arrangement with the goal to find early and effective responses to conflict and crisis situations.

87 Viljoen (2007), 457.

88 V. O. Nmehielle, 'Seven Years in Business: Evaluating Developments at the African Court on Human and Peoples' Rights', 17 Law Democracy \& Dev (2013), 317, 318. 


\subsection{Human Rights wing of the African Union (AU)}

Originally, the Organization of African Unity (OAU) aimed to ensure security, peace for and decolonization of the African continent. With the end of the 20th century, human rights gained much more importance not only in Africa but also worldwide. Thus, the OAU developed several legal instruments aiming to ensure the protection of human rights, such as the African Charter on Human and Peoples' Rights. Consequently, at the time of its establishment, the African Union (AU) had to already consider the protection of human rights. This development and its effectiveness shall be explained below.

\subsubsection{Human Rights instruments of the African Union (AU)}

As mentioned above, in the last two decades of its existence, the OAU focused on the adoption of several human rights-related instruments. However, during its existence, the instrument which gained most importance was the African Charter on Human and Peoples' Rights. Additionally, the African Charter on the Rights and the Welfare of the Child, the Protocol to the African Charter on Human and Peoples' Rights on the Rights of Women and the African Charter on Democracy, Elections and Good Governance were introduced. After the dissolution of the OAU, the African Union assumed responsibility for all of these instruments.

\section{a) The African Charter on Human and Peoples' Rights - the beginning of a new era}

The establishment of the Universal Declaration of Human Rights steadily contributed to similar efforts on the global and regional level. One of such developments was the adoption of the European Convention for the Protection of Human Rights and Fundamental Freedoms in 1950, by the Council of Europe. The Convention is a legally binding instrument aimed at protecting human rights and other fundamental freedoms. ${ }^{89}$

The establishment of the European Convention of on Human Rights and Fundamental Freedoms of 1950 recognizing human rights on the level of the European continent promoted the creation of two other human rights related instruments in different regions. Consequently, in 1969 the American Charter on Human Rights and in 1981 the African Charter on Human and Peoples' Rights were adopted. The African Charter on Human and Peoples' Rights - also known as Banjul Charter - entered into force on 21 October 1986. In order to give effect to rights that are protected by the Charter, the parties are expected to adopt legislative measures at the domestic level. ${ }^{90}$

Besides the early developments within the European continent, most recently members of the Association of Southeast Asia established the Human Rights Declaration of the Association of Southeast Asian Nations (ASEAN) during their meeting

89 Adede (1995), 104

90 See: Art. 1 on the 1981 African Charter on Human and Peoples' Rights. 
in 2012 in Phnom Penh, Cambodia. The ASEAN Declaration so far is a non-binding instrument and as such, does not provide for an effective human rights protection mechanism, but instead is a text stipulating common human rights standard. ${ }^{91}$

Nowadays, the African Union provides for many different treaties that involve human rights. Besides the African Charter, the Protocol to the African Charter on Human and Peoples' Rights on the Rights of Women in Africa, the 1969 African Union Convention Governing Specific Aspects of the Refugee Problem in Africa, the 1998 Protocol to the African Charter on Human and Peoples' Rights, the African Charter on Democracy, Elections and Governance as well as the African Charter on the Rights and Welfare of the Child, have all been enacted.

aa) Historical background to the establishment of the African Charter on Human and Peoples' Rights

Initially, the OAU did not address the protection of human rights. Several attempts were undertaken to establish a human rights mechanism for the African Continent. ${ }^{92}$ After more and more grave human rights violations took place on the continent - such as the crimes committed by dictator Idi Amin ${ }^{93}$ in Uganda or Jean-Bédel Bokassa ${ }^{94}$ in Equatorial Guinea - the need for an effective human rights protection mechanism has gained more attention. ${ }^{95}$

The implementation of a human rights system promoting the rule of law on African level was proposed for the first time during the Lagos Congress on Primacy of Law in 1961 in form of a Convention on Human Rights as well as a Human Rights Tribunal which was modelled after the earlier European Commission on Human Rights. Even though the proposal was repeated during many sessions, no action was taken, despite the recommendations of the UN. The demand was mostly ignored since many African States were still engaged with matters regarding decolonization. ${ }^{96}$

91 G. J. Naldi \& K. D. Magliveras, 'The ASEAN Human Rights Declaration', 3 Int'l Hum Rts L Rev (2014), 184; P. Malanczuk, 'Association of Southeast Asian Nations (ASEAN)', in R. Wolfrum (ed), Max Planck Encyclopedia of Public International Law (2007).

92 U. O. Umozurike, The African Charter on Human and Peoples' Rights (1997), 189.

93 Idi Amin was a Ugandan military officer and politician and President of Uganda from 1971 until 1979 (for more details see: H. Kyemba, State of Blood: The Inside Story of Idi Amin (1977).

94 Jean-Bédel Bokassa was the ruler of the Central African Republic and its successor, the Central African Empire from 1966 until 1979 (see: K. A. Appiah \& H. L. Jr Gates (eds), Africana: The Encyclopedia of the African and African American Experience (1999)).

95 Alston \& Goodman (2013), 1026.

96 C. R. M. Dlamini, 'Towards a Regional Protection of Human Rights in Africa: The African Charter on Human and Peoples Rights', 24 Comp \& Int'l LJ S Afr 2 (1991), 189, 270. 
African States were bound to respect human rights by the United Nations Covenants (ICCPR) and the International Covenant on Economic, Social and Cultural Rights (ICESCR)), which oblige the States to respect the listed civil and political, social, cultural and economic rights. The Declaration of 1948 however, is of non-binding character for the parties. ${ }^{97}$

Nevertheless, during many different conferences on the African level taking place between 1970 and $1973,{ }^{98}$ the wish to create an African human rights mechanism was requested by many parties. In the meantime, the International Commission of Jurists $^{99}$ organized several conferences in Africa in order to discuss the rule of law issue. During those summits, the participants of the meetings emphasized the importance of the implementation of a human rights system within Africa. Moreover, in 1979, the UN convoked a seminar on the Establishment of Regional Commissions on Human Rights with Special Reference to Africa, where African States participated very actively. The seminar, which took place in Monrovia, Liberia, resulted in the 'Monrovia proposal for the setting up of an African Commission on Human Rights' and was then submitted to the OAU by the UN Secretary General ${ }^{100} .{ }^{101}$

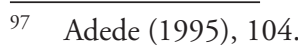

98 Seminar on the Realization of Economic and Social Rights with Particular Reference on the Developing Countries in Lusaka, Zambia 23 June -4 July 1970; Conference of African Jurist on (the) African Legal Process and the Individual in Addis Ababa, Ethiopia 19-23 April 1971; Seminar on the Study of New Ways and Means for Promoting Human Rights with Special Attention to the Problems and Needs of Africa in Dar-es-Salaam, Tanzania 23 October-5 November 1973, see inter alia: G. Baricako, 'Introductory Preface' in M. Evars \& R. Murray, The African Charter on Human and Peoples' Rights: The System in Practice (2002), 1, 5.

99 The International Commission of Jurists is comprised of up to sixty lawyers dedicated to ensuring respect for international human rights standards through law. The Commissioners are known for their experience, knowledge and fundamental commitment to human rights. The composition of the Commission aims to reflect the geographical diversity of the world and its many legal systems. (see: The International Commission of Jurists - The Commission, available at: https:// www.icj.org/commission/, (last visited: 7 August 2020).

100 The Secretary-General of the United Nations is the head of the United Nations Secretariat and is one of the principal organs of the United Nations. The Secretary-General is the chief administrative officer of the United Nations. Former U.S. President Franklin D. Roosevelt defined the UN Secretary-General to be a 'world moderator'. In addition, Art. 97 of the UN Charter entitles the Secretary-General to be the 'chief administrative officer' of the United Nations. As per the UN Charter, the Secretary General shall act as the chief administrative officer 'in all meetings of the General Assembly, of the Security Council, of the Economic and Social Council and the Trusteeship Council and shall perform other functions as are entrusted to him by these organs. The current Secretary-General is António Guterres from Portugal (as of 24.07.2018), (for more details see: K Skjelsbæk, 'The UN Secretary-General and the Mediation of International Dispute', 28 Journal of Peace Research 1 (1991), 99.

101 Hansungule (2000), 272; Baricako (2002), 5. 
In the same year, the OAU finally decided 'to initiate concrete steps in this direction within the framework of the organisation'. ${ }^{102}$ Consequently, a symposium was organized in Monrovia in 1979 to discuss the question 'What kind of Africa by the Year 2000?' During the symposium, the establishment of a human-rights department within the African Union was considered.

In July 1979, during the meeting of Heads of State and Government the creation of an 'African-human rights defence mechanism' was decided upon.

Thus, scholars on human rights issued a draft of a legal instrument protecting human rights. Before the adoption of the raft by the OAU Council Ministers in Banjul, The Gambia in January 1981, which was adopted by the OAU Council of Ministers in Banjul, The Gambia in January 1981.

However, before the Ministers finally adopted the draft, they changed the draft substantially. For instance, they removed the phrase in the preamble stipulating the co-cooperation with non-African States. They argued that to do otherwise would contradict the intended regional character of the Charter. In reality, the co-operation with non-African States, such as European States, in fact, made the implementation of the Charter possible. After all, the Commission depends on the funding from the Western States. ${ }^{103}$

After the implementation of the amendments, the Assembly of Heads of State and Government adopted the Charter in Nairobi, Kenya in June 1981. In order to become operative, the Charter needed the adherence or ratification of a simple majority of the Member States. The Charter eventually came into force on 21st October 1986, after the required number of States ratified it in accordance to Art. 63(3) of the Charter ${ }^{104}{ }^{105}$

With the adoption of the Charter, African leaders finally recognized that human rights are of international significance. With the implementation of the Charter, the reassigned principle of 'non-interference' cannot justify the violation ${ }^{106}$ of human rights, since African leaders are forced to respect the provisions of the Charter. Eventually, all African States who were members of the OAU, except Eritrea, ratified the Charter. ${ }^{107}$

\footnotetext{
102 Hansungule (2000), 272.

103 Dlamini (1991), 191.

104 In accordance with the provisions set down in Art. 63(3), the '[...] present Charter shall come into force three months after the reception by the Secretary General of the instruments of ratification or adherence of a simple majority of the Member States of the Organisation of African Unity'.

105 Hansungule (2000), 275.

106 Before the implementation of the Charter on Human and Peoples' Rights, the principle of non-interference in the domestic affairs of Member States was being consistently upheld (Hansungule (2000), 317).

107 Hansungule (2000), 317.
} 
bb) Structure of the African Charter on Human and Peoples' Rights

In the Preamble of the Charter, the ratifying parties affirmed 'the inalienable right of all people to control their own destiny.' Furthermore, the Preamble states that 'freedom, equality, justice and dignity are essential objectives for the achievement of the legitimate aspirations of the African peoples. ${ }^{108}$

Moreover, the Preamble of the African Charter also reads that ' $\mathrm{t}]$ ]he Member States of the Organisation of African Unity parties to the present Charter shall recognise the rights, duties and freedoms enshrined in this Charter.'

The Charter itself is essentially divided into three parts: the first part deals with the rights and duties that are protected by the Charter. The second part elaborates on the measures to safeguard the rights of the first pArt. Furthermore, this part ensures the set-up of the African Commission on Human and Peoples' Rights, which will be discussed in detail below. The last part provides for provisions regarding the commencement of the Commission.

The structure of the African Charter in many parts is similar to that of the International Covenant on Civil and Political Rights of the United Nations, which first enumerates the protected rights and then specifies the provisions for the establishment of the UN Commission. ${ }^{109}$

The African Charter essentially provides for all civil and political rights that are defined as the 'first generation of rights'. ${ }^{110}$ First generation rights include such rights that are fundamental to civil and political nature and that are essential for liberty and political life. However, the African Charter also protects second and third generation rights, including socio-economic rights. ${ }^{11}$ Thus, it includes rights from all three generations. ${ }^{112}$ Second generation rights inter alia evolved the right 'to work under equitable and satisfactory conditions' ${ }^{113}$ and the right to education. ${ }^{114}$

While second-generation rights are related to equality, third generation rights go beyond the mere civil and social rights. ${ }^{115}$ They include the right to a sustainable environment as well as the right to international peace and security. The most

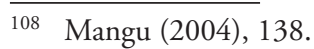

109 See: Art. 28 onwards of the 1966 International Covenant on Civil and Political Rights; for more information on the Convenant see: C. Tomuschat, 'International Covenant on Civil and Political Rights', in R. Wolfrum (ed), Max Planck Encyclopedia of Public International Law (2010).

110 D. Shelton, Remedies in International Human Rights Law (2015), 239.

111 P. Amoah, 'The African Charter on Human and Peoples' Rights - An Effective Weapon for Human Rights?', 4 Afr J Int'l \& Comp L (1992), 227.

112 Viljoen (2007), 237.

113 See: Art. 15 of the 1981 African Charter on Human and Peoples' Rights.

114 See: Art. 17 of the 1981 African Charter on Human and Peoples' Rights.

115 Hansungule (2000), 285.
} 
far-reaching consequence is that these third-generation rights are as 'unequivocally' justiciable as all other rights in the Charter. ${ }^{116}$ The African Charter was the first international human rights treaty to make socio-economic rights justiciable. ${ }^{117}$

In more detail, the African Charter provides for several rights whose restriction is not permitted and which therefore, need to be respected by the signatory parties in all circumstances. These rights include the right to non-discrimination based on 'race, ethnic group, color, sex, language, religion, political or any other opinion, natural and social origin, fortune, birth or other status' ${ }^{118}$ In addition, Art. 2 ensures the equality before the law as well as the equal protection before the law. Art. 1(1) of the International Convention on the Elimination of All Forms of Racial Discrimination $^{119}$ gives a legal, internationally recognized definition of the term 'discrimination' stating that:

[A]ny restriction, exclusion, restriction or preference which has the purpose or effect of nullifying or impairing the recognition, enjoyment or exercise, on an equal footing, of human rights, fundamental freedoms and peoples' rights in the civil, political, economic, social and cultural or any other field of public or where appropriate private life. ${ }^{120}$

Moreover, the Charter prohibits any forms of slavery and slave trade. Taking into consideration the International Convention on the Abolition of Slavery of 1926 and the 1959 Supplementary Convention on the Abolition of Slavery, Slave Trade and Institutions and Practices similar to Slavery, slavery includes 'debtor's bondage, serfdom and other institutions and practices.' ${ }^{121}$ The 1974 Working Group on Slavery expanded the definition by including 'sale of children - especially girls for prostitution, the exploitation of the prostitution of others, child labour, apartheid and colonialism'. ${ }^{122}$

Furthermore, the Charter protects the rights to life, freedom of expression, freedom of conscience, freedom of association, liberty, freedom of assembly and of movement, which may become limited by the domestic law of the Member States.

\footnotetext{
116 Ibid.

117 F. Viljoen \& L. Louw, 'State Compliance with the Recommendations of the African Commission on Human and Peoples' Rights, 1994-2004', 101 Am. J. Int'L 1 (2007), 1, 18.

118 G. W. Mugwanya, Human Rights in Africa - Enhancing Human Rights Through the African Regional Human Rights System (2003), 191.

119 The International Convention on the Elimination of All Forms of Racial Discrimination is a convention being implemented by the United nations. Being a third-generation human rights instrument, the Convention commits its members to the elimination of racial discrimination as well as the promotion of understanding among all races (see: L. Natán, The U.N. Convention on the Elimination of All Forms of Racial Discrimination (1980)).

120 Umozurike (1997), 30.

121 O. C. Eze, The African Charter on Rights and Duties and Enforcement Mechanisms (2009), 65.

122

Umozurike (1997), 32.
} 
Some of the provisions protecting third generation rights are the right to development (Art. 23) and the right to a satisfactory environment (Art. 24). Furthermore, Arts. 27 to 29 include obligations and duties of individuals, which is unique within the human rights system. ${ }^{123}$

The African Charter was highly influenced by other human rights conventions such as the European Convention for the Protection of Human Rights and Fundamental Freedoms. ${ }^{124}$ However, according to Okeere: 'The Charter is different from the European and the Inter-American human rights systems in several aspects: the Charter recognises duties as well as rights; it codifies peoples' rights as well as individual rights; and protects economic, social and cultural rights. ${ }^{125}$

Unlike the European and American Convention, the African Charter does not provide for a provision on capital punishment and furthermore does not prohibit forced labor or the right of nationals to be expelled. ${ }^{126}$

cc) The issue of the 'claw-back' clauses of the African Charter

The African Charter incorporates several 'claw-back' clauses, which inter alia encompass following wording: 'except for reasons and conditions previously laid down by law', 'subject to law and order' ${ }^{127}$, 'within the law', 'provided that he abides by the law' ${ }^{128}$. The 'claw-back' clauses cause many problems with regards to the interpretation of the Charter by the African Commission on Human and Peoples' Rights, as shown by the two following communications. The formulation of the claw-back clauses is one of the main reasons for criticism of the Charter since most textual analyses are afraid of a circumvention of those provisions through domestic law. ${ }^{129}$

In the case of Legal Resources Foundation v. Zambia, ${ }^{130}$ the Commission had to deal with the issue of 'claw-back' clauses.

123 Amoah (1992), 227.

124 See more details in: B. O. Okere, 'The Protection of Human Rights in Africa and the African Charter on Human and Peoples' Rights: A Comparative Analysis with the European and American Systems', 6 Hum Rts Q 2 (1984), 141.

125 G. Muigai, 'From the African Court on Human and Peoples' Rights to the African Court of Justice and Human Rights' in M. Ssenyonjo (ed), The African Regional Human Rights System 30 Years after the African Charter on Human and Peoples' Rights (2012), 265, 268.

126 P. Tlakula, 'The African Commission on Human and Peoples' Rights: Promotion and Protection of Rights under the African Charter on Human and Peoples' Rights Rule of Law, Regional and National Enforcement of Human Rights in Africa', 39 S Afr YB Int'l L Supplement (2014), 5, 9; see more details in: Gerald L Neumann; 'American Convention on Human Rights (1969)' in R. Wolfrum (ed), Max Planck Encyclopedia of Public International Law (2007); S. Peers Steve; A. Ward, (ed) 'The EU Charter and of Fundamental Rights: politics, law and polity' (2004).'

127 See: Art. 8 of the 1981 African Charter on Human and Peoples' Rights.

128 See: Arts.10(1) and 12(1) of the 1981 African Charter on Human and Peoples' Rights.

129 Viljoen (2007), 244.

130 Legal Resources Foundation v. Zambia, Communication No. 211/98 (2001), Communication of 7 May 2001. 
In this case, the Commission found that 'claw-back' provisions in the Charter could not be used by a State party to avoid its international obligations under the Charter. In this case, Zambia tried to rely on the limitation provisions of the right against discrimination, which is contained in its own Constitution. It argued that the right against discrimination was, in terms of Zambian law, restricted with regard to several aspects. Thus, in their opinion, there was no breach on the provisions of the African Charter, which recognized that the enjoyment of the rights of the Charter has to be in accordance with the law. However, the Commission rejected this argument stating:

The Commission has argued forcefully that no State Party to the Charter should avoid its responsibilities by recourse to the limitations and 'claw-back' clauses in the Charter. It was stated following developments in other jurisdictions, that the Charter cannot be used to justify violations of sections of it. The Charter must be interpreted holistically, and all clauses must reinforce each other. The purpose or effect of any limitation must also be examined, as the limitation of the right cannot be used to subvert rights already enjoyed. Justification, therefore, cannot be derived solely from popular will, as such cannot be used to limit the responsibilities of the State parties of the Charter. $^{131}$

In another communication - Organisation Mondiale Contre la Torture and Others $v$. Rwanda - the Commission interpreted the phrase of a 'claw-back' clause 'in accordance with law' as including the necessity to correspond with international law. ${ }^{132}$

In Media Rights Agenda and Others v. Nigeria, ${ }^{133}$ the Commission found that the rights guaranteed in the Charter might only be limited under the provisions of Art. 27(2) of the Charter stating that: 'The rights and freedoms of each individual shall be exercised with due regard to the rights of others, collective security, morality and common interest.' Thus, any State limiting any of the rights with a 'clawback' clause needs to provide that the limitation took place under the provisions of Art. 27(2) of the Charter. ${ }^{134}$

dd) Criticism on the African Charter on Human and Peoples' Rights

Taking into consideration the enormous human rights violations and the abandonment of democratic institutions within the African continent in the 1970s, the establishment of the Charter was unquestionably a big advancement towards better recognition of those rights. ${ }^{135}$

131 Tlakula (2014), 8.

132 Viljoen (2007), 349.

133 Media Rights Agenda and Others v. Nigeria, Communication Nos. 105/93, 128/94, 130/94 and 152/96, Communication of 31 October 1998.

134 Ibid., para 68; see also: Prince v. South Africa, Communication No. 255/2002, Communication of 23 November -7 December 2004, para 43.

135 Amoah (1992), 226. 
The Charter provides for many rights that are listed in the Universal Declaration of Human Rights, as well as the International Covenant on Civil and Political Rights. However, some rights, which are guaranteed by other international human rights instruments such as the European and American Convention, are not considered. For example, the right to form and join trade unions and the right to equal protection of all children whether born in or out of wedlock are not mentioned in the African Charter. Moreover, some rights, such as the freedom of assembly and association and the freedom to free practicing of religion, are not as clearly mentioned as in other human rights instruments.

Likewise, the principle of fair trial is only vaguely guaranteed. The African Charter, in Art. 7, mentions the right of an accused to have his or her cause heard - however, the provision does not mention the right to have recourse to a court or the right to a public hearing. ${ }^{136}$

Most provisions in the Charter include 'claw-back' clauses, which may undermine the effective implementation of the guaranteed rights and therefore need to be revised in the near future. ${ }^{137}$ Many of these clauses contain 'nebulous and open-ended phrases', which are not compatible to clauses 'necessary in a democratic society' as employed in the European Charter of Fundamental Rights ${ }^{138} .{ }^{139}$ Such clauses allow States to suspend some rights protected by the Charter by enacting domestic legislation. ${ }^{140}$

In order to prevent the negative impacts of such clauses, the Charter should, instead of 'claw-back' clauses insert a provision on so-called indispensable rights and another clause, specifying rights from which States may derogate in certain circumstances - the clause should define the conditions under which the State is allowed to deviate from the provisions. ${ }^{141}$

Furthermore, the Preamble establishes an 'open door' policy regarding the access to the African Charter on Human and Peoples' Rights and thus differs enormously from other regional Charters protecting human rights. The above-mentioned provision differs substantially from the American Convention, ${ }^{142}$ which provides that all

136 Tlakula, (2014), 9.

137 Umozurike (1997), 32.

138 For instance, the European Human Rights Convention (ECHR) contains similar clauses, see: Arts. 8-11 of the ECHR.

139 Ndulo (2008), 182, for more details on the European Charter see: S. de Vries, U. Bernitz, S. Weatherill (eds.), The EU Charter of Fundamental Rights as a binding instrument: five years old and growing (2015).

140 M. Swart, 'Alternative fora for human rights protection? An evaluation of the human rights mandates of African sub-regional courts', 3 Journal of South African Law (2013), 437, 443.

141 Ibid.

142 The American Convention on Human Rights, also known as Pact of José, is an international human rights instrument. Many Western countries in San José, Costa Rica, adopted it in 1969. It came into force after the presentation of the 11th instrument of ratification in 1978. The bodies being entitled to oversee the compliance with the Convention are the Inter-American Commission on Human Rights' and the Inter-America court on Human rights, which are both 
States need to ensure 'not to violate an individual's right and may also have the obligation to adopt affirmative measures necessary and reasonable under the circumstances to ensure the full enjoyment of the rights. '143 Thus, taking into consideration the wording, the suspicion could arise that the African Charter does not necessarily demand its Member States to protect the human rights on the same level. This poor wording may result from an attempt make to Charter acceptable to governments which worry about their national sovereignty. ${ }^{144}$

Finally, the effectiveness of the Charter depends on the role of the African Commission and the African Court on Human and Peoples' Rights as well as on the willingness of the States parties to harmonize their domestic laws with the provisions of the Charter. ${ }^{145}$

However, African governments realized that the membership to an international human rights treaty would not really prevent the governments from the violation of human rights. ${ }^{146}$

In contrast to the African Charter, the Statute of the Council of Europe guarantees the protection of human rights. Art. 3 of the Statute of the Council of Europe (1949) stipulates that:

$[E]$ very member of the Council of Europe must accept the principles of the rule of law and of the enjoyment of all persons within its jurisdiction of human rights and fundamental freedoms, and collaborate sincerely and effectively in the realization of the aim of the Council as specified in Chapter one.

Art. 4 states: '[a]ny European State which is deemed to be able and willing to fulfil the provisions of Art. 3 may be invited to become a Member of the Council of Europe by the Committee of Ministers. ${ }^{147}$ Thus, to become a member of the Council, the respective State has to accept and protect all standards provided in the Convention. ${ }^{148}$

The African Charter was adopted extremely quickly by the African governments - there was never an international treaty, besides the UN Convention on the Rights of the Child (CRC) ${ }^{149} 1989$, that was adopted this quickly. The reason for this was not that African governments suddenly recognized the significance of human rights

institutions set up by the Organisation of American States; (see: G. L. Neumann, 'American Convention on Human Rights (1969)', in R. Wolfrum (ed), Max Planck Encyclopedia of Public International Law (2008).

143 See: Preamble of the 1969 American Convention on Human Rights.

144 Okere (1984), 142.

145 Amoah (1992), 228.

146 Hansungule (2000), 267.

147 Ibid., 266.

148 For more details see: A. van Aaken, I. Motoc, The European Convention on Human Rights and general international law, (2015).

149 The United Nations Convention on the Rights of the Child (CRC) is a human rights treaty which sets out the civil, political, economic social health and cultural rights of children. Currently, all Member States of the UN have ratified the Convention except of the United States. The Convention was adopted on 20 November 1989 and eventually came into force on 2 September 
but rather that the Charter did not have any access restrictions, as opposed to the European Convention. Therefore, every African State could become a party to the Charter without disclosing information about the status of its human rights record and level of democratic governance. ${ }^{150}$

\section{b) The African Charter on the Rights and Welfare of the Child (ACRWC)}

Apart from the African Charter, the African Charter on the Rights and Welfare of the Child (ACRWC) was adopted by the OAU Assembly in July 1990 in order to ensure the adequate protection of children. The ACRWC entered into force in November 1999. The ACRWC is the world's first regionally binding instrument recognizing the rights of children. On the global level, the UN drafted the Convention on the Rights of the Child, which was adopted in 1989 and entered into force in 1990. The Convention was the first international instrument recognizing the rights of the children. ${ }^{151}$

As of August 2013, 47 African States ratified the Charter. According to Frans Viljoen, one of the reasons for the implementation of the Charter was the situation of children living under discriminatory circumstances, apartheid and socio-economic conditions in Africa. ${ }^{152}$

Paragraph 4 of the Preamble of the ACRWC inter alia states that the said Charter was established in order to recognize the situation of African children which 'remains critical due to the unique factors of the socio-economic, cultural, traditional and developmental circumstances, natural disasters, armed conflicts, exploitation and hunger.'

The Charter in Art 1(1) asks its Member States to 'recognise the rights, freedoms and duties enshrined in this Charter' and to 'undertake the necessary steps, in accordance with their Constitutional processes and with the provisions of the present Charter, to adopt such legislative or other measures as may be necessary to give effect to the provisions of the Charter. ${ }^{\prime 53}$ For instance, the Charter led the Republic of South Africa to reform child justice system as well as the 1983 Child Care Act. The effective implementation, however, depends on political will and the adoption of budgets. ${ }^{154}$

1990; (see: Child Rights Information Network (2008), Convention on the Rights of the Child available at: https://www.crin.org/en/home/rights/convention, (last visited: 5 September 2018)).

150 E. A. Ankumah, 'The African Commission on Human and Peoples' Rights', 16 Kluwer Law International (1996), 6.

151 D. Olowu, 'Protecting Children's Rights in Africa: A Critique of the African Charter on the Rights and Welfare of the Child Children's Rights in Africa', 10 Int'l J Child Rts (2002), 127.

152 A. G. Assefa, 'Advancing Children's Rights in Africa: The Role of the African Children's Charter and Its Monitoring Body', 2 Mekelle U LJ (2014), 66, 72.

153 D. M. Chirwa, The Merits and Demerits of the African Charter on the Rights and Welfare of the Child Children's Rights in Africa', 10 Int'l J Child Rts 2 (2002), 157.

154 T. Davel, 'The African Charter on the Rights and Welfare of the Child, Family Law and Children's Rights', 35 De Jure (2002), 295 et seq. 
Thus, the Charter, which applies to both, second-and third generation rights does adopt an integral approach, encouraging that these rights are interdependent but also indivisible. Similar to the CRC, the ACRWC aims to set out a minimum standard for the continent. ${ }^{155}$

Two parts make up the Charter, with the first part dealing with substantive provisions regarding the rights of the child, the second part safeguards the machinery and temporal provisions. ${ }^{156}$

Similar to the UN Convention, the Charter provides for four general principles. These are the principle of non-discrimination in Art. 3 of the ACRWC, the principle of best interest of the child under Art. 4 the right to life, survival and development of the child as per Art. 5 as well as the right of a child to be heard with their views in accordance with Art. 4(2). The best interest principle constitutes a criterion on which States have to orientate its policies and laws on. The meaning of the views of the child principle is that children have to be heard and that their views should be taken into consideration seriously, whereas the term development in the right of life should be interpreted in a broad sense recognizing not only physical but also mental health. ${ }^{157}$

Furthermore, the Charter contains inter alia the right to education and the right to health and health services as well as the right to protection from any forms of torture, inhuman and degrading treatment. In this regard, Art. 16 of the Charter obliges all parties to take all appropriate measures to protect children from all forms of violence or abuse, which are also recognized by the Convention. ${ }^{158}$

In order to ensure the welfare of children, the Charter provides for inter alia the right to education (Art. 11), to leisure, recreation and cultural activities (Art. XIII), health and health services (Art. 14) and the freedom from economic exploitation (Art. 15). Furthermore, the Charter limits the recruitment of children in armed conflicts (Art. 22 (2)), whereas the Convention in Art. 38 allows the recruitment of those children who are above 15 years of age. In addition, the Charter prohibits the marriage of children (Art. 21 (2)) as well as the recognition of rights of internally displaced children (Art. 23), which extends the provisions of Art. 22 of the Convention on the Rights of the Child. ${ }^{159}$

The Charter does not only provide for substantial human rights standards but also includes provisions on the establishment of own institutions.

The Committee of Experts on the Rights and Welfare of the Child governs the implementation of the provisions of the Charter. However, until today the Committee has not yet been very active since it only received very few communications. ${ }^{160}$

\footnotetext{
155 Chirwa (2002), 158.

156 Assefa (2014), 73.

157 Olowu (2002), 129.

158 Ibid.

159 Ibid.

160 Ibid.
} 
In general, the provisions of the Charter have been described as the 'most progressive achievement of all the regional systems, as it is the only system to provide a comprehensive mechanism for the protection and promotion of children's rights at a regional level. ${ }^{161}$ For instance, in comparison with the CRC, the Charter provides for a more human rights-centred approach, in using the expressions 'every child'. Furthermore, Art. 2 of the Charter defines a child as any human being below the age of 18 without attaching any limitations, whereas Art. 1 of the CRC provides for an exception, namely when the applicable domestic law specifies a lower age for attaining majority. ${ }^{162}$

The most distinctive feature in comparison to the Convention is that the African Charter on the Rights and Welfare of the Child provides for a Committee, which is set-up under Art. 32 and is mandated to receive communications which may be submitted by any person relating to any matter that is covered by the Charter (Art. 44(1)). Thus, the Committee may cover such rights of the children not recognized by most constitutions of the Member States through (non-binding) recommendations.

In conclusion, the ACRWC, in general, does intensify the recognition of the rights of children within the continent. The Charter reflects in its distinctive rights the reality within the continent where in many areas children are exploited. Before the adoption of the Charter, children in Africa essentially had no rights. Now they may issue a communication involving a human rights violation, in accordance with Art. 44. However, the Charter has its limitations, for example, in the socio-and economic conditions which make it impossible for governments to achieve all rights provided in the Charter. Furthermore, so far there has been a lack of recognition of the Charter and a lack of academic debate and therefore, the ACRWC remains, thus far, quite ineffective. ${ }^{163}$

\section{c) Protocol to the African Charter on Human and Peoples' Rights on the Rights of Women}

In 2003, the Heads of State and Government adopted the Protocol to the African Charter on Human and Peoples' Rights on the Rights of Women in Maputo, Mozambique. The Protocol entered into force in 2005 , after the ratification by the $15^{\text {th }}$ State. As of today, most African States have ratified the Charter.

The Protocol is of legally binding character and aims to mark a new beginning with regard to the protection of women's human rights within the African continent. The Protocol is comparable to the UN Convention on the Elimination of All

161 Assefa (2014), 74.

162 Chirwa (2002), 158.

163 A. Lloyd, 'Evolution of the African Charter on the Rights and Welfare of the Child and the African Committee of Experts: Raising the Gauntlet Children's Rights in Africa', 10 Int'l J Child Rts 2 (2002), 182 et seq. 
Forms of Discrimination Against Women (CEDAW). ${ }^{164}$ In its Preamble, the Protocol acknowledges that many women in Africa still suffer from human rights abuses based on their gender. Furthermore, the Protocol expressively refers to women at risk of traditional and harmful practices, which violate human rights law and thus demands States to prohibit such practices.

The Protocol provides for a legal framework urging all African governments to pay attention to the rights of women. In particular, the Protocol aims to ensure that human rights of women are considered and thus specifies a minimum standard with regard to the treatment of women. ${ }^{165}$

Besides the Protocol, Art. 2 of the African Charter refers to the principle of non-discrimination reinforcing that every woman shall enjoy the rights contained in the Charter without discrimination. ${ }^{166}$

Art. 3 further obliges the State to secure the women's right to dignity and thus prohibits any exploitation or degradation as well as any verbal or sexual violence. Additionally, Art. 4 expressively underlines the rights of life of women and its integrity.

Amongst other provisions, Art. 14 of the Protocol guarantees the sexual and reproductive health of women. The Protocol allows for abortions in case of rape or where the continuation of the pregnancy would jeopardize the life of the mother. ${ }^{167}$

With regard to cultural practices, the Protocol in Art. 5 states that '[...] forms of harmful practices which negatively affect the hum rights of women and which are contrary to recognised to international standards' shall be outlawed by Member States. The Protocol further guarantees several economic and social welfare rights, such as the equality of both sexes before the law, access of women to law and legal aid ${ }^{168}$ as well as the right to education, ${ }^{169}$ the right to a healthy and sustainable environment ${ }^{170}$ and to sustainable development. ${ }^{171}$

164 M. S. Nsibirwa, 'A Brief Analysis of the Draft Protocol to the African Charter on Human and Peoples Rights on the Rights of Women', 1 Afr Hum Rts LJ, (2001), 40, 42.

165 C. Ocran, Christine, 'Protocol to the African Charter on Human and Peoples' Rights on the Rights of Women in Africa Recent Developments', 15 Afr J Int'l \& Comp L (2007), 48.

166 F. Viljoen, 'An Introduction to the Protocol to the African Charter on Human and Peoples' Rights on the Rights of Women in Africa', 16 Wash \& Lee J Civil Rts \& Soc Just (2009), 11, 18.

167 N. I. Aniekwu, 'The Additional Protocol to the African Charter on Human and People's Rights: Indications of Capacity for African Municipal Systems', 13 Law Democracy \& Dev 2 (2009), 28.

168 Art. 8 of the 2003 Protocol to the African Charter on Human and Peoples' Rights on the Rights of Women in Africa.

169 Art. 12 of the 2003 Protocol to the African Charter on Human and Peoples' Rights on the Rights of Women in Africa.

170 Art. 18 of the 2003 Protocol to the African Charter on Human and Peoples' Rights on the Rights of Women in Africa.

171 Art. 19 of the 2003 Protocol to the African Charter on Human and Peoples' Rights on the Rights of Women in Africa. 
In order to implement the obligations under the Protocol, States are urged to take effective legal measures to punish all forms of public and private forms of violence. ${ }^{172}$

However, some governments still do not fully recognize or implement the provisions of the Protocol.

Co-existing with the African Charter, the Protocol to women's rights may lead to a progressive interpretation of the African Charter, since the Protocol can be used as a guide to address issues of human rights, as the Commission is mandated through the African Charter to go beyond the Charter when interpreting its rights. Thus, since the establishment of the Protocol with its new provisions, the Charter may be interpreted more progressively. ${ }^{173}$

It appears that the establishment of the Protocol has finally solved the conflict between cultural practices still existing throughout the continent and human rights. Several studies of the last years show that within African cultures patriarchal principles are still supported and thus, the subject of protection of women's rights was often disregarded before the establishment of the Protocol. With the establishment of the Protocol, cultural practices involving women are tolerated only as long as they are compatible with human right standards. ${ }^{174}$ The establishment of the regional treaty heralded a shift in the minds of African governments. ${ }^{175}$ NGOs, such as the Solidarity for African Women's Rights, a coalition of several groups, ensured the publication of the Protocol. It is, however, doubtful that States will provide for a speedy ratification of the provisions of the Protocol. Besides that, there is a visible lack of effective enforcement throughout the whole continent. Thus, Member States have to inter alia ensure sufficient funds in order to safeguard the realization of the rights mentioned in the Protocol. ${ }^{176}$

\section{d) African Charter on Democracy, Elections and Governance}

The African Charter on Democracy, Elections and Governance was adopted during the $8^{\text {th }}$ ordinary session of the Assembly of Heads of States in January 2007 and came into force in February 2012. ${ }^{177}$ The Charter's aim is to reinforce the commitment of the Member States of the African Union regarding the protection of the principle of democracy as well as the rule of law and human rights. The Charter required the ratification of 15 States to become effective. It was ratified by Burkina Faso, Ethiopia, Guinea, Ghana, Lesotho, Mauritania, Rwanda, Sierra Leone, South

\footnotetext{
172 Ocran (2007), 148.

173 Nsibirwa (2001), 52

174 M. B. Berna, 'The Cultural Factor and Women's Rights within the African Charter on Human and People's Rights and Its Protocol', 2015 Law Annals Titu Maiorescu U (2015), 11, 24 et seq.

175 Ibid.

176 Ocran (2007), 152.

177 Vandeginste (2013), 5.
} 
Africa, and Zambia. ${ }^{178}$ The Charter tries to inter alia push through a political change by requiring regular and transparent elections that are conducted by independent electoral bodies. ${ }^{179}$

As discussed during the conference of the International Law Association in South Africa, principles such as democracy and good governance form part of public international law and are closely related to the protection of human rights. ${ }^{180} \mathrm{On}$ the international level, those principles are recognized in inter alia the UN Charter, the International Covenant on Civil and Political Rights (ICCPR) and the International Covenant on Economic, Social and Cultural Rights (ICESCR). ${ }^{181}$ Thus, within the framework of international law, this Charter is the only one that declares democracy and free and fair elections to be an individual fundamental right. Similar to the UN Declaration of Human Rights, the Charter is a set of practices and standards regarding the rule of law, freedom of opinion, the right to association and the right to participate in elections. ${ }^{182}$

The Charter, furthermore, is of much importance with regard to the African Peer Review Mechanism (APRM) - which will be discussed in chapter 2.8.1. However, the Charter goes beyond these mechanisms and allows the Peace and Security Council (PSC) of the African Union to act when deep lapses in governance arise. Amongst others, such a scenario comes up in case of an unconstitutional change of government. In accordance with Art. 30 of the Constitutive Act, the PSC may in such circumstances 'suspend the said State party from the right to exercise its right to participate in the activities of the Union.' ${ }^{183}$

In 2012, a study on the efficiency of this international document was carried out in both - Francophone and Anglophone countries. The study was implemented by the West Africa Election Observers Network (WAEON), a coalition of nonpartisan citizen observation groups from 11 countries in West Africa. ${ }^{184}$ The study was implemented in order to discuss possibilities of implementing the Charter within the region of West Africa. The study found that many citizens in West Africa are not aware of the existence of the Charter. Furthermore, governments are very hesitant

178 African Commission, Ratification Table: African Charter on Democracy, Elections and Governance, available at: http://www.achpr.org/instruments/charter-democracy/ratification/ (last visited: 6 July 2018).

179 See: Art. 2 No. 3 of the 2007 African Charter on Democracy, Elections and Governance.

180 Berna (2015), 24 et seq.

181 A. MB Mangu, 'African Peer-Review Mechanism and the Promotion of Democracy and Good Political Governance in Africa, The Conference Paper', 32 S Afr YB Int'l L (2007), 2.

182 Ibid.

183 Vandeginste (2013), 6 et seq.

184 Groups from Burkina Faso, Ghana, Guinea, Liberia, Mali, Nigeria, Senegal, Sierra Leone, Togo and Cote d'Ivoire (see: WAEON I West Africa Elections Network http://www.waeon.org/, (last visited: 5 September 2018). 
regarding its implementation and recognition. ${ }^{185}$ Therefore, the African Charter needs to be promoted throughout the continent in order to raise awareness about its existence and its principles.

\subsection{Human rights institutions and procedures}

The African Union provides for several institutions entitled to enforce the provisions of the African Charter but also to ensure the compliance with other international treaties such as the UN Covenant on Human and Political Rights within the African continent. These institutions, as discussed below, are: the African Commission on Human and Peoples' Rights (2.6.1), the African Court on Human and Peoples' Rights and the Pan-African Parliament (2.6.8).

\subsubsection{The African Commission on Human and Peoples' Rights}

The first regional institution that was set up with the aim to protect human rights on a regional level in Africa was the African Commission on Human and Peoples' Rights. The Commission, however, is not formally an organ of the AU. ${ }^{186}$ The African Charter on Human and Peoples' Rights made provisions for the creation of the African Commission on Human and Peoples' Rights and for it to be the supervisory institution of the provisions of the Charter. During the 'Monrovia Conference' in 1979, it was decided to establish the African Commission on Human and Peoples' Rights. Before the conference, the UN Commission for Human Rights held many Conferences in order to sensitize African governments on the establishment of institutions that protect human rights. ${ }^{187}$

As a quasi-judicial body, the Commission is subordinated to the political machinery of the AU. ${ }^{188}$ Similar to the African Commission, an Inter-American and a European Commission were set-up in order to ensure the effective implementation of human rights. The European Commission, however, was abolished in May 1994 and thus, the European Court on Human Rights now undertakes the former tasks of the Commission. ${ }^{189}$

185 NDI, Promoting the AU Charter on Democracy. Elections and Governance in West Africa (28 June 2013), available at: https://www.ndi.org/WAEON-symposium, (last visited: 20 March 2018).

186 Alston \& Goodman (2013), 1028.

187 Muigai (2012), 267.

188 G. Bekker, 'The African Commission on Human and Peoples' Rights and Remedies for Human Rights Violations' (2013), 13 Hum Rts L Rev (2013), 500.

189 R. Murray, 'Serious or Massive Violations under the African Charter on Human and Peoples' Rights: A Comparison with the Inter-American and European Mechanisms Part A', 17 Neth Q Hum Rts (1999), 110, see also: M. Oetheimer, G. Palomares, 'European Court of Human Rights (ECtHR)', in R. Wolfrum (ed), Max Planck Encyclopedia of Public International Law 
In contrast to the American and the European systems, which both provided for a commission and a court to supervise their respective human rights documents, the actors of the OAU - due to several reasons - initially only pushed towards the creation of the African Commission. ${ }^{190}$

The Commission started to operate in 1987 , holding a very broad mandate, which included the protection and promotion of human rights and the interpretation of the Charter on Human and Peoples' Rights. ${ }^{191}$ Thus, it was implemented under the provisions of Art. 30 of the African Charter on Human and Peoples' Rights. ${ }^{192}$ Today, the Commission is situated in the capital of The Gambia, Banjul. ${ }^{193}$

\section{a) The internal structure of the African Commission on Human and Peoples' Rights}

In order to ensure an appropriate functioning, the African Charter - beyond the rights that shall be protected - provides several provisions for setting up an appropriate internal structure of the Commission. Apart from the legal provisions providing for rules regarding the nomination for the commissioners, and also rules regarding its procedure, the Protocol of the Commission also regulates the number of sessions per year and the structure and functioning of the Secretary.

aa) The composition of the African Commission on Human and Peoples' Rights The Commission is composed of eleven members that are elected by a secret ballot at the Assembly of the African Union from a list that is issued by the State parties. ${ }^{194}$ Arts. 30-44 of the African Charter set out the procedure on the elections of the commissioners.

Under the Charter, the members 'are chosen from amongst African personalities of the highest reputation, known for their high morality, integrity, impartiality and competences in matters of human and peoples' rights. ${ }^{195}$ Whilst electing the members of the Commission, the AU Assembly of Heads of State and Government needs to ensure an equal gender representation as well as equal geographic representation. ${ }^{196}$

The Member States nominate the candidates to be elected by the Commission. ${ }^{197}$ The elected members generally serve a six-year term and may become re-elected.

(2007); G. Neumann, 'Inter-American Court of Human Rights (IACtHR)', in R. Wolfrum

(ed), Max Planck Encyclopedia of Public International Law (2007).

190 G. Bekker, 'The African Court on Human and Peoples' Rights: Safeguarding the Interests of African States', 51 Journal of African Law 1 (2007), 151, 152 et seq.

191 Mugwanya (2003), 348 et seq.

192 Ankumah (1996), 1.

193 Viljoen (2007), 312.

194 Ankumah (1996), 13.

195 See: Art. 31 of the 1981 African Charter on Human and Peoples' Rights.

196 Viljoen (2007), 312.

197 M. Killander, 'The African Commission on Human and Peoples' Rights' in M. Ssenyonjo (ed), The African Regional Human Rights System - 30 Years after the African Charter on Human and 
The first commissioners to be elected by the former Assembly of the OAU all had close relations to their governments. ${ }^{198}$ In accordance with Art. 31(1), particular consideration is given to persons providing for legal expertise Art. 31(2) further states that the commissioners are entitled to serve in their personal capacity. ${ }^{199}$

The membership within the Commission only ends following a death or resignation of the commissioner or in case the member stops to discharge his duties for any reason where temporary absence is not counted. ${ }^{200}$

The members of the Commission do enjoy full independence during their tenure at the offices. No Member is supposed to have more than one person in the Commission at the same time. During the first years of existence of the Commission, many commissioners represented governmental opinions, ${ }^{201}$ which conflicted with the independence of their mandate. ${ }^{202}$

The Chairperson and the Vice-Chairperson are chosen among the members and serve for two years, Art. 42(1) of the Charter. The Bureau - as further organ of the Commission - is enabled to coordinate the activities of the Commission and to supervise the Secretary. Furthermore the Bureau is eligible to coordinate the promotional and protectoral activities of the commissioners, Rule 13 of the Rules of Procedure.

In accordance to Rule 17 of the Rule of Procedures, the institution provides for a Secretariat, which facilitates administrative, logistical and technical support to the Commission. Amongst other things, the Secretary draws up the agenda of the ordinary sessions. The staff of the Secretariat is generally chosen by the Chairperson of the Commission.

The election procedure of the Commission is highly influenced by the Assembly of Heads of State and Governments, with the Commission being elected by the Heads of State and Government through secret ballot, as per Art. 32 of the Charter. Further, the Charter in Art. 31(1) does not require preceding practice with regard to human rights but only sufficient knowledge in human rights matters.

bb) Procedure within the African Commission on Human and Peoples' Rights

The Rules of the Procedure of the Commission, set up in accordance with Art. 42 of the African Charter, provide - besides legal provisions regarding the election of the Commissions' members - also several rules with regard to the internal organization of the Commission.

Peoples' Rights (2012), 236; see also: Eze (2009), 215.

198 Eze (2009), 216.

199 Alston \& Goodman (2013), 1027.

200 Ankumah (1996), 14.

201 For instance, two members also served as Attorney General and Minister of interior during their term in office. In many African countries, the position of the minister of international affairs dealing with State security matters - represents the second highest position in the government; (see: Eze (2009), 216).

Eze (2009), 216. 
The Commission, according to Rule 26(1), meets twice a year. ${ }^{203}$ The sessions last from 10 to 15 days and take place in March/April and October/November. ${ }^{204}$ The public may be excluded from the sessions if necessary, Rule 31. According to Rules 64 and 65, the Commission may invite States, national liberation movements, and specialized institutions in order to be heard on human rights related matters.

After a session is concluded, the Commission submits a report on its activities to the Assembly of Heads of State and Government of the African Union, Art. 54 of the Charter. After the Executive Council inspects the reports, the Commission publishes them in order to ensure its accessibility to all people, as per Rule 38 of the Rules of the Commission.

If necessary, the Commission may install special working groups and Committees during its sessions. The Committees generally sit when the Commission is not in session. Unless decided otherwise, the sessions of the Committees are held in private. After finishing a session, the Commission usually issues a communiqué and submits its report to the actual chairperson of the African Union. ${ }^{205}$

Special Rapporteurs are established in conformity of Art. 46 of the Charter, stating that the Commission 'may resort any appropriate method of investigation.' Thus, Special Rapporteurs are able to seek and to receive information by signatory States to the Charter. ${ }^{206}$ At time of writing, the Commission installed Special Rapporteurs in the following fields: rights of women, human rights defenders, refugees, asylum seekers, prisons and conditions of detention, freedom of expression and access to information, migrants and internally displaced persons.

Besides that, NGOs have an observer status within the Commission and thus have a special position in the Commission. In accordance with Rule 72, NGOs do not have any voting rights, but they are entitled to be informed about the provisional agenda of each session. Despite the lack of voting rights, NGOs may, however, participate actively in the sessions of the Commission and are entitled to submit cases to the Commission. NGOs are hence entitled to submit 'shadow reports', to propose an agenda during the Commission sessions, and inter alia provide logistical and other support to the Commission. ${ }^{207}$

\section{b) The mandate of the African Commission on Human and Peoples' Rights}

Until the creation of the African Court on Human and Peoples' Rights (discussed in more detail below at 2.5.3), the Commission was the only supervising organ to ensure the implementation of the provisions of the African Charter.

203 Viljoen (2007), 315.

204 U. O. Umozurike, 'The African Charter on Human and Peoples' Rights: Suggestions for More Effectiveness', 13 Ann Surv Int'l \& Comp L (2007), 185.

205 Ankumah (1996), 18.

206 See: Killander (2012), 241.

207 Shelton (2008), 545. 
Art. 45 of the African Charter sets out the several mandates of the Commission. ${ }^{208}$ Accordingly, functions of the Commission are to:

1. $[\mathrm{P}]$ romote human and peoples' rights and in particular

(a) To collect documents, undertake studies and research on African problems in the field of human and peoples' rights, organize seminars, symposia and conferences and disseminate information, encourage national and local institutions concerned with human and peoples' rights, and should the case arise, give its views or make recommendations to governments.

(b) To formulate and lay down principles and rules aimed at solving legal problems relating to human and peoples' rights and fundamental freedoms upon which African governments may base their legislations.

(c) Co-operate with other African and international institutions concerned with the promotion and protection of human and peoples' rights.

2. Ensure the protection of human and peoples' rights under conditions laid down by the present Charter.

3. Interpret all the provisions of the present Charter at the request of a State party, an institution of the OAU or an African Organisation recognised by the OAU.

4. Perform any other tasks, which may be entrusted to it by the assembly of Heads of States and Governments.

The Commission was established in order to promote and protect human and peoples' rights and to interpret the African Charter on Human and Peoples' Rights. ${ }^{209}$ However, in contrast to international human rights courts, the Commission cannot pass judgments that are enforceable in the Member States. As a consequence, the African Commission is not equivalent to the European or Inter-American Court, or to the later-on established African Court on Human and Peoples' Rights. In fact, Art. 45 of the Charter enables the Commission only to

collect documents, undertake studies and researches on African problems in the field of human and peoples' rights, organize seminars, symposia and conferences, disseminate information, encourage national and local institutions concerned with human peoples' rights and, should the case arise, give its views or make recommendations to governments.

However, unlike the European Commission and the Inter-American Commission, the African Commission provides a much broader mandate - being both, protective and promotional. However, similarly to the Inter-American Commission on $\mathrm{Hu}$ -

\footnotetext{
208 Ndulo (2008), 186.

209 See: Art. 45 of the 1981 African Charter on Human and Peoples' Rights.
} 
man Rights (acting under Art. 16 (3) of its Statute), the African Commission also only meets in regular or special sessions and hence, is not a permanently standing $\operatorname{organ}^{210}$

\section{aa) Promotional activities}

The Commission is tasked with the protection and promotion of human rights.

The promotional mandate of the Commission aims to ensure greater attention to human rights of African people around the continent. Where people are aware of their rights, the protection of their rights is most likely. Therefore, promotion of human rights throughout the continent is one of the fundamental tasks of the Commission. ${ }^{211}$

The promotional activities of the Commission may be divided into two categories. The first category includes the gathering and analyzing of data and information. The Commission may then present the findings of its studies and research in different fora to attract the attention of the African population with regard to human rights. ${ }^{212}$ The second category of activities is, so to say, advisory in its nature - the Commission has the mandate to make recommendations to the governments whenever it is deemed necessary. ${ }^{213}$

Therefore, the Commission may fulfill their duties through the facilitation of education and publication of its findings. Under the African Charter, the promotional duty also contains the obligation to gather information, undertake several studies with regard to human rights issues affecting the African continent, and to organize conferences, seminars and symposia on the related issues. ${ }^{214}$

During each ordinary session, each commissioner has to brief the Commission on his or her promotional activities that have been undertaken between the sessions. In order to fulfill the promotional obligations, the commissioner may visit human rights organizations, universities as well as other institutions within the countries assigned to him. On occasion of such visits, the commissioners shall hold meetings with government officials as well as AU and UN organs at place. ${ }^{215}$

However, those promotional activities, in general, only reach the parts of the population in urban areas which normally have a better educational background. ${ }^{216}$

210 Viljoen (2007), 317.

211 Ankumah (1996), 21.

212 Ibid.; see also: A. M. Ibrahim, 'African Commission on Human and Peoples' Rights and Human Rights Education: Much Buzzing, Still No Honey', 35 S Afr YB Int'l L (2012), 123.

213 In order to fulfil the human rights mandate, the Commission introduced so-called documentation centre, which published several books that deal with human rights; (for more information see: The African Commission on Human and Peoples' Rights, available at: https://www.achpr. org/documentationcenter, last visited: 5 September 2018).

214 Eze (2009), 217; see also: Art. 45(1)(a)) of the 1981 African Charter on Human and Peoples' Rights.

215 Tlakula, (2014), 15.

216 Killander, (2012), 242. 
In order to fulfill the mandate, the Commission can utilize several Special Mechanisms carried out by Special Rapporteurs who work in groups or committees to investigate and report on human rights issues. Recently, the Commission appointed six Special Rapporteurs to investigate, monitor and to report accusations of human rights violations by Member States to the African Union. ${ }^{217}$

Since the recommendations issued by the Commission are not of binding character, the Commission remains quite ineffective in terms of human rights protection. Moreover, the issue of non-confidence in the expertise of the Commission impede the efficiency of the institution. ${ }^{218}$ Besides that, the work of the Commission is limited due to lack of funding. ${ }^{219}$

In summary, the promotional activities of the Commission, such as the organization of several seminars and conferences on human rights-related topics, are not yet set-up effectively. Such activities may, however, increase the awareness of and provide more attention to human rights within the continent.

\section{bb) Protective activities}

Next to promotional activities the Commission is charged with taking protective measures.

The protective activities constitute the main task of the Commission and have the highest potential regarding the protection of human rights.

Art. 45(2) of the African Charter gives the Commission the mandate to 'ensure the protection of human and peoples' rights under conditions laid down by the present Charter'. This competence aims to ensure the enjoyment of the rights and freedoms of the Charter through the collaboration with several stakeholders, such as governments but also human rights organizations. ${ }^{220}$

With regard to protective matters, the Commission is competent to receive communications and complaints which constitute the core protection function. ${ }^{221}$ Until 2014, the Commission received more than 350 of such complaints. ${ }^{222}$ The procedure of communications and complaints is ruled upon in Chapter III of the Charter - that is Arts. 46 through 59. Apart from States, individuals and NGOs are competent to submit complaints related to provisions of the African Charter.

Moreover, Art. 58 provides that as part of the protection mandate, the Commission undertakes fact-finding missions to States that are party to the Charter. The Commission is allowed to conduct investigations into allegations of serious or massive human rights violations. During the fact-finding mission of the Commission, people are interviewed, photos are taken, and on-site visits are undertaken. After

217 Viljoen (2007), 392.

218 Tlakula, (2014), 15.

219 F. Viljoen, 'The Realisation of Human Rights in Africa through Sub-Regional Institutions', 7

African Yearbook of International Law 1(1999), 185, 209.

220 Tlakula, (2014), 17.

221 Ibrahim (2012), 123.

222 Tlakula (2014), 88. 
finishing the fact-finding mission, a report is submitted to the Commission ${ }^{223}$ If the Commission identifies gross human rights violations, it is allowed to start investigations without the submission of a communication by a respective complaint, as per Art. 58(3).

\section{1) Inter-state complaints}

Inter-state communications take place when one State party to the African Charter alleges that another State party violated a right or freedom guaranteed in the Charter. In order to initiate a dispute, the complaining State, first and foremost, needs to issue a statement to the State accused of violating human rights. The complaining State is entitled to forward a copy to the Commission and the Secretary General. Due to the procedural requirements, the addressed State is required to forward written explanations to the enquiring State. ${ }^{224}$

The Charter in this context provides for two different mechanisms: in accordance with Art. 49, a State party is allowed to issue an inter-state complaint directly to the Commission. The other option set out in Art. 48 allows the accusing State party to issue a formal communication to the accused State's attention, which is also submitted to the Commission. ${ }^{225}$

Regarding inter-state complaints, the general requirement of exhaustion of the local remedies does not apply since a sovereign State cannot fall under the jurisdiction of a foreign court. ${ }^{226}$

As a consequence, until 2018, the Commission dealt with very few communications affecting inter-state complaints. One of the inter-state complaints was Democratic Republic of Congo v. Burundi, Rwanda and Uganda ${ }^{227}$.

The communication was filed by the Democratic Republic of Congo alleging the violation of rights protected by the African Charter on Human and Peoples' Rights and other international Protocols, such as the UN Charter and the 1970 UN Declaration on Friendly Relations. The State claimed that the respondents sent their armed forces to the Democratic Republic of Congo, which occupied the eastern parts of the country and carried out mass violations of human rights. The violations related to the mass killing of civilians in the area as well as the cutting off of electricity supply for hospitals. ${ }^{228}$

The Commission found that the occupation by the respondents was in violation of Art. 23 of the Charter, stating that people of the affected region have the right to national and international peace and security. ${ }^{229}$

223 Tlakula, (2014), 18.

224 Ankumah (1996), 22.

225 Shelton (2008), 544.

226 Ankumah (1996), 23.

227 Democratic Republic of Congo v. Burundi, Rwanda and Uganda, Communication No. 227/99, Date of Communication: 15-29 May 2003.

228 Ibid., paras 10-11.

229 Ibid., para 23. 
Furthermore, the Commission found that Arts. 16 and 17 of the African Charter - the right to best attainable physical and mental health as well as the right to education - were also violated due to halting electricity supply for homes, schools and hospitals.

The Commission found several other violations of the provisions of the African Charter. For instance, the violation of Art. 2 of the African Charter which guarantees non-discrimination in the enjoyment of rights - as the actions of respondents were directed against several victims on the basis of their national origin. ${ }^{230}$

Lastly, the Commission required the respondents to pull out their forces from the territory of Congo. The Commission further states that Burundi that did not come up with a reaction is committed to cooperate with the communication of the Commission. The communication of the Commission however did not lead to reassurance in the affected area. ${ }^{231}$

In another case, Libya claimed that the stationing of US troops in Zaire and Chad was violating human rights. Despite the fact that the US is not party to the African Charter, the ambassador of Libya insisted upon filing the complaint. However, the communication was declared inadmissible by the Commission. ${ }^{232}$

Since only very few inter-state complaints have been submitted to the Commission, the efficiency and effectiveness of inter-state complaints cannot be properly evaluated. The inter-state decisions are of non-binding character; thus no state party is generally obliged to implement the decision of the Commission. However, an inter-state complaint may imply great interest in the public and the media. Thus, even if the State does not implement the recommendations, people in the affected region may learn about the complaint, which may increase awareness of the existence of protected rights. Consequently, it is likely that people may become more motivated to submit complaints to the Commission if human rights violation is feared, especially when they are aware of such rights.

2) Complaints before the Commission by individuals and NGOs

Besides the competencies of the Commission with regard to inter-state communications, the institution is competent to receive communications issued by non-state entities. Since its establishment, the Commission heard several cases submitted by individuals and NGOs in which it has applied and interpreted different provisions of the African Charter.

By help of this mechanism individuals of the signatory States of the Charter as well as NGOs have a possibility to hold a State accountable for a human rights violation.

Arts. 55 to 59 of the Charter govern such complaints, which mainly constitute a procedural right for individuals and NGOs.

\footnotetext{
230 Ibid., para 88.

231 R. Murray \& D. Long, The Implementation of the Findings of the African Commission on Human and Peoples' Rights Vol. 1 (2015), 54.

232 Umozurike (2007), 183.
} 
Under the provisions of the Charter, individuals or NGOs may submit a written complaint to the Commission if they believe that actions taken by a State party violate human rights. The NGO itself does not need to be affected, but it may invoke a complaint on behalf of individuals. ${ }^{233}$ In contrast to complaints in the former European Commission, the acceptance through the African Commission of 'other communications' is mandatory once a State accedes to the Charter. ${ }^{234}$

(a) Procedural requirements

The African Charter provides some rules regulating the admissibility requirements for individuals and NGOs to the Commission. In accordance with Art. 55(2), the communication is only considered if the majority of members of the Commission decide to do so. As per Art. 56(7) the matter in dispute cannot be submitted to any other international dispute settlement procedure while the Commission investigates and decides upon the matter.

However, the provisions of the Charter and the Rules of procedure do not elaborate the meaning of standing and thus do not necessitate a link between the person submitting the communication and the victim of the violation. ${ }^{235}$ The former Rules of Procedure even stated, that a non-victim could submit a communication if the victim was unable to do so. The regulation was removed in 1995 without any further indications. In the communications Malawi Association and Others v. Maurita$n i a^{236}$ and Constitutional Rights Project v. Nigeria, ${ }^{237}$ the Commission indicated that persons other than the victims themselves are competent to submit communications to the Commission. ${ }^{238}$ Later in the Ogoniland ${ }^{239}$ Communication, the Commission stated that there needs to be some kind of link between the victim and the complaint. The complainant does not need to act with the permission of the victim but there needs to be a public interest in the complaint. ${ }^{240}$

Besides the adherence to the general requirements, the exhaustion of local remedies is required: Pursuant to the provisions of Art. 50 'all local remedies, if they exist, have to be exhausted, unless it is obvious to the Commission, that the procedure of achieving these remedies would be unduly prolonged.' The main reason

\footnotetext{
233 Tlakula (2014), 17.

234 Viljoen (2007), 323

235 Tlakula (2014), 17.

236 Malawi African Association and Others v. Mauritania, African Commission on Human and Peoples' Rights Communication Nos. 54/91, 61/91, 98/93, 164/97, 196/97 and 210/98, Communication of 11 May 2000.

237 Constitutional Rights Project v. Nigeria, Communication No. 102/93, Communication of 22-31 October 1998.

238 M. P. Pedersen, 'Standing and the African Commission on Human and People's Rights', 6 Afr Hum Rts LJ (2006), 411.

239 Social and Economic Rights Action Centre (SERAC) and another v Nigeria, Comm. No. 155/96, Date of Communication: 27 October 2001.

240 Ibid., para 49.
} 
for this requirement is that it prevents the Commission from becoming a court of first instance. The same requirement is present not only at the Intra-American and European Commissions but also at the UN Human Rights Commission. ${ }^{241}$

The Commission rejected several communications due to the lack of adherence to the requirement of exhaustion of local remedies.

In the communication Samuel T. Muzerengwa \& 110 Others v. Zimbabwe $e^{242}$ a complaint against the Republic of Zimbabwe on behalf of Samuel T. Muzerengwa and 110 families (the victims) was brought before the Commission, alleging that the Buhera Rural District Council evicted the victims from their village in a manner that was inhumane, unfair, and disproportionate. The complainant alleged that the evictions did not meet international standards for forced evictions as the executive and the courts failed to provide an effective remedy. The complainant, therefore, alleged the breach of Arts. 1, 2, 3, 5, 10(1), 13(1) and (3), 14, 16, 17, 18(1) and (4), 21 and 22 of the African Charter by the respondent State. ${ }^{243}$

The Commission found that the complainant had not given the domestic courts the opportunity to remedy the merits or substance of the complaint. The Commission argued this in spite of the fact that the High Court and Supreme Court had dismissed the case because the petitioners had approached the local courts to rule on procedural matters rather than on the merits. The Commission found the communication to be inadmissible under Arts. 56(5) and (6) of the African Charter. ${ }^{244}$

In the Gambian Mental Health case, ${ }^{245}$ a communication which was submitted by two mental health advocates on behalf of two patients who were detained in a psychiatric unit under the provisions of the Gambian Lunatics Detention Act, the Commission referred to the indigence of the people being represented through the respective communication. The Commission found that the complainant needs to allege that local remedies are not available. It is then up to the involved State to prove that the local remedies are available. If this occurs, the complainant again needs to prove that he had exhausted all remedies or that despite an availability of the remedy, it was insufficient. ${ }^{246}$

241 C. E. Jr Welch, 'The African Commission on Human and Peoples' Rights: A Five-Year Report and Assessment', 14 Hum Rts Q (1992), 48; J. Crawford, T. Grant, 'Exhaustion of Local Remedies', in R. Wolfrum (ed), Max Planck Encyclopedia of Public International Law (2007); for more details on the UN Commission on Human Rights see: B. Rudolf: 'United Nations Commission on Human Rights/United Nations Human Rights Council', in R. Wolfrum (ed), Max Planck Encyclopedia of Public International Law (2007); for the Inter-American Commission see: C. Grossmann, 'Inter-American Commission on Human Rights (IACommHR)', in R. Wolfrum (ed), Max Planck Encyclopedia of Public International Law (2007). Samuel T. Muzerengwa \& 110 Others v. Zimbabwe, Communication No. 306/05, Communication of 27 October 2001.

Ibid., para 51.

245 Purohit and Moore v. The Gambia, Communication No. 241/01, Communication of 15-29 May 2003.

246 Purohit and Moore v. The Gambia, paras 25 et seq. 
In a further case of Anuak Justice Council v. Ethiopia, ${ }^{247}$ the complainant stated that domestic remedies are not available since the principle of fair hearing is not possible in Ethiopia due to executive interference. The Republic of Ethiopia, however, stated that a number of cases involving human right violations are pending before the Federal Circuit Court. ${ }^{248}$ Since the complainant was not able to prove the exhaustion of local remedies, the Commission declared the case inadmissible. ${ }^{249}$ The communication Luke Munyandu Tembani and Benjamin John Freeth (represented by Norman Tjombe) v. Angola and Thirteen Others ${ }^{250}$ was submitted on behalf of Mr. Luke Munyandu Tembani and Mr. Benjamin John Freeth (the victims) against the fourteen Member States of the Southern African Development Community, the Summit of Heads of State of the Southern African Development Community (SADC Summit), and the Council of Ministers of SADC. ${ }^{251}$

The background to communication was, that the Zimbabwean Government issued an executive order depriving the first victim of his title to agricultural land and forced him to leave his land. He complained to the Southern African Development Community Tribunal (SADC Tribunal), and the Tribunal ruled in his favor. After Zimbabwe failed to comply with the SADC Tribunal's judgment, the first victim referred the case to the SADC Summit for measures to be taken against Zimbabwe, which were granted but similarly defied by Zimbabwe. Similarly, the second victim, who represented a group of people, had obtained a favorable ruling by the SADC Tribunal, which remained unimplemented by the Republic of Zimbabwe. Two decisions of the SADC Summit in 2010 and 2011 suspended the SADC Tribunal and rendered its decisions unenforceable. Bringing his communication against the fourteen Member States that comprise the SADC, as well as the SADC Summit, and the SADC Council, the complainant alleged that these actions constituted violations of Arts. 7 and 26 of the African Charter, as well as the SADC Treaty and the International Covenant on Civil and Political Rights (ICCPR). The Commission considered that the requirement to exhaust local remedies could be dispensed of in this case as it would be unduly prolonged: it would require the complainant to file cases before the domestic courts of 14 States. ${ }^{252}$ The Commission furthermore stated that it could only base its decision on claims of violations of the African Charter by Member States in accordance with Art. 45(2) of the African Charter. The Commission agreed with the complainant that, in appropriate cases, Member States of international organizations could bear direct responsibility for the wrongful acts and omissions of that international organization, especially where the rights of third par-

\footnotetext{
247 Anuak Justice Council v. Ethiopia, Communication No. 229/2005, Communication of 11-25 May 2006.

248 Ibid., paras 44.

249 Ibid., para 62.

250 Luke Munyandu Tembani and Benjamin John Freeth (represented by Norman Tjombe) v. Angola and Thirteen Others, Communication No. 409/12, Communication of 30 April 2014.

251 Ibid., para 1.

252 Ibid., para 4.
} 
ties were involved. However, the Commission found that there was no violation of Art. 7 of the African Charter, as the article imposes an obligation on States to ensure the right to a fair trial at the domestic level, rather than in a regional court. ${ }^{253}$ The Commission also considered that Art. 26 imposed no obligation on the respondent States vis-a-vis the SADC Tribunal, noting that the article applies to national courts which exercise compulsory jurisdiction over individuals who have no possibility of opting out of the coverage of the judicial authority of those courts. Accordingly, the Commission found no violation of Art. 26.254

(b) Procedure

As first step, the Communications that are meant for the African Commission are to be directed to the Secretary which registers the Communication. The Secretary then forwards the respective Communication to the Commission which decides if the Communication shall be considered, Art. 56 of the Charter.

The Commission in accordance to Art. 45 of the Charter tries to secure a friendly settlement between the parties. In order to reach friendly settlement the Commission may also accept written and oral submissions and may also hold hearings. ${ }^{255}$

If the parties do not agree on an amicable solution the merit stage follows, where the Commission will discuss the case on camera, deliberating whether a human rights violation took place. The State party involved, which at this stage already received all the information regarding the case, is now given the chance to give a statement before the decision on merits is taken. ${ }^{256}$

Art. 52 of the Charter states that '[a]fter having obtained from the States concerned and from other sources all the information it deems necessary and after having tried all appropriate means to reach an amicable solution based on respect of human and people's rights [...] the Commission issues a recommendation on the matter.' Thus, the Commission at this stage usually engages with the involved parties - especially with the involved State. For instance, in the case of RHADDO $v$. Zambia ${ }^{257}$, both parties appeared before the Commission in order to find an amicable solution. However, most parties do not appear before the Commission and thus, the latter tries to reach the parties e.g. through written correspondence. ${ }^{258}$

If the Commission finds a violation of human rights, and if there is no chance of the matter being resolved, the Commission may forward a protocol to the Assembly of Heads of State and Government with its recommendations on the matter.

However, the Commission may need a long period of time to finally elaborate a recommendation on the matter and thus, it may be necessary to safeguard the rights of the victim during this interim period. This fact may relate to the long procedure

\footnotetext{
253 Ibid., para 135.

254 Ibid., para 143.

255 Shelton (2008), 544.

256 Hansungule (2000), 312.

257 RHADDO v. Zambia, Communication No. 71/92, Communication of 21-31 October 1996.

258 Hansungule (2000), 312.
} 
periods of the Commission. If the Commission declares the Communication to be admissible, it needs to forward the complaint to the involved State. Such decisions may in practice take several years as the Commission usually tries to reach a friendly settlement through negotiations with the parties. ${ }^{259}$

However, the Commission lacks an efficient fact-finding practice and thus the developed practices are more of $a d$ hoc character. Until today the procedure requires a considerable amount of time. Besides that, in accordance with Arts. 60 and 61, the Commission - issuing a recommendation - may get inspired by a number of international human rights treaties.

In addition, the recommendations of the Commission need to be forwarded to the Assembly of Heads of State for approval. This procedure, however, restricts the efficiency of the Commission since it is dependent on the political will of the Heads of State and Government.

The Commission stated that the disregard of provisional measures is in violation of Arts. 5 and 16 of the Charter, which require State parties to give effect to the rights provided for within the Charter as well as the right to a fair trial. ${ }^{260}$

The Mohamed L. Diakité v. Gabon ${ }^{261}$ case for example illustrates the issue concerning the large amount of time taken by the Commission to decide a complaint. The case was received in 1992 and was only finalized eight years later, in May 2000.

Thus, imposing provisional measures is necessary in order to avoid gross violations of human rights. However, similar to the communications, the provisional measures are of non-binding character. Thus, involved State parties do not need to comply with any of such measures.

(c) Enforcement and enforcement remedies

However, the recommendations of the Commission are not binding for the involved State. This fact leads to several issues with regard to their enforcement. ${ }^{262}$

Consequently, in 2006 the Commission adopted a resolution on the Importance of the Implementation of the Recommendations of the African Commission on Human and Peoples' Rights. The Resolution inter alia calls on State parties to adopt the communications without delay. It is argued that besides the Resolution of the Commission, the recommendations get binding character through the adoption of the annual activity reports of the commissioner through the Assembly of Heads of State and Government, as per Art. 54 of the Charter. The activity reports usually include the recommendations by the Commission. ${ }^{263}$

\footnotetext{
259 Doebbler (2003), 13.

260 Ibid., para 117.

261 Mohamed L. Diakité v. Gabon, Communication No. 73/92, Communication of 18-27 April 1994.

262 Eze (2009), 222.

263 R. Murray \& D. Long, (2015), 55.
} 
The Charter does not provide for remedies regarding the recommendations of the Commission on human rights violations. Furthermore, most recommendations remain silent regarding any such remedies. The Charter, however, empowers the Commission to make any recommendations that are deemed useful in the particular case. Initially, it was thought that the implementation of remedies would be outside of the mandate of the Commission and thus any remedies should have been introduced via the political level - e.g. the Assembly of Heads of State and Government. In addition to the recommendation of payment of an adequate compensation, the Commission did publish the communication locally or urged the withdrawal of troops. However, taking into consideration the provisions of the Charter, one can come to a conclusion that remedies must be issued in order to give effect to the Charter in cases of human rights violations. Following the Ogoniland case ${ }^{264}$ and the Mauritian Widows ${ }^{265}$ case, the Commission most recently issued a landmark decision involving remedies in detail. ${ }^{266}$

In the case of Institute for Human Rights and Development in Africa and Others $v$. Democratic Republic of Congo, ${ }^{267}$ the Commission found that the Government of the Democratic Republic of Congo should be held responsible for the 2004 massacre of about 70 people in Kilwa. The Commission awarded - amongst other reparations a landmark compensation of US\$2.5 million to the victims and their families. ${ }^{268}$

The complaint was brought before the Commission on behalf of eight victims in November 2010 by the NGO Rights and Accountability in Development (RAID) based in the United Kingdom and the NGO Action-Against Impunity and Human Rights (ACIDH), based in Congo and the Institute for Human Rights and Development in Africa, based in Banjul, The Gambia.

The background to this decision was the following: in 2004, armed rebels tried to take control of Kilwa, which is located in the Democratic Republic of Congo. Outside from Kilwa, the Australian Anvil Mining Company held a silver mine. The rebels while trying to take control of Kilwa killed more than 70 civilians. After several investigations, it was determined that Anvil Mining provided logistical support to the military action in Kilwa. ${ }^{269}$

Domestic proceedings were brought against involved Congolese soldiers and employees of Anvil Mining without success. Claims were also brought against Anvil employees in Canada and Australia, where Anvil Mining holds offices but also without success. ${ }^{270}$

264 The Social and Economic Rights Action Center and the Center for Economic and Social Rights v. Nigeria, Communication No. 155/96, Communication of 13 - 27 October 2001.

265 Malawi African Association and Others v. Mauritania (2000).

266 Viljoen (2007), 355 et seq.

267 Institute for Human Rights and Development in Africa and Others v. Democratic Republic of Congo, Communication No. 393/10, Communication of 9-18 June 2016.

268 Ibid., para 154.

269 Ibid., paras 2 et seq.

270 Ibid., paras 17 et seq. 
In its communication, the Commission found the Congolese government was responsible for 9 violations of the African Charter relating to arbitrary arrest, extrajudicial executions, torture, disappearances, and forced displacement of the population. It also found the articles relating to the independence of the judiciary, the right to housing and development had been violated - the articles of the Charter that it found had been violated included Arts. 1, 4, 5, 6, 7(1) (a), 7 (1) (c), 14, 22 and 26. The Commission condemned Anvil Mining for its role in the violations and urged the Government of the Republic of Congo to start new criminal investigations and to punish the involved staff of the company. ${ }^{271}$

As of yet, the Congolese Government has not implemented the decision of the Commission and thus did not reward the compensation to the victims.

The absence of a uniform enforcement system for communications of the Commission does complicate its enforcement. Mostly, the reasons for the non-compliance with the communications of the Commission are of political and not of legal nature. ${ }^{272}$

\section{cc) Examination of state reports}

In addition to the promotional and protective measures, the Commission is mandated to examine state reports. Under this procedure, every two years Member States are required to submit a report on legislative and other measures being undertaken by the State to give effect to human rights. Many Member States, however, do not take the obligation seriously.

After the Commission expressed its readiness to receive the reports, only 11 States have submitted their records by 2006. As of yet, about 15 States have never submitted a report. Only five Member States submitted all required reports. ${ }^{273}$ The examination of the reports generally happens in public with the representation of NGOs and the African civil society, which could have a positive impact on the measures being implemented by the States. ${ }^{274}$ This mandate is seen as the 'backbone of the mission of the Commission. ${ }^{275}$

With the $29^{\text {th }}$ session of the Commission held in Tripoli, Liberia, the Commission started to adopt concluding observations after the end of the examination of the submitted state reports. Moreover, the records are of a more serious character: 'States delegates are methodically questioned by all members of the Commission on the implementation of the charter in the countries under review, including on issues such as gender equality, prison conditions, discrimination based on sexual orientation, and minority groups and indigenous populations. ${ }^{276}$

271 Ibid., paras 43 et seq.

272 Viljoen \& Louw (2007), 32.

273 Ankumah (1996), 24 et seq.

274 M. A. Mindizie, 'The African Commission on Human and Peoples' Rights' in J. Akokpari \&

D. S. Zimbler (eds), Africa’s Human Rights Architecture (2008), 209.

275 Ankumah (1996), 25.

276 Mindizie (2008), 209. 
The task to examine state reports relating to human rights in every State does not constitute an effective observation feature since most States do not submit a record. The Commission, on the other hand, does not provide for a mechanism penalizing the non-submission of such a record. In addition, the Commission only provides for limited resources and time. Thus, it is doubtful if the Commission would be able to examine reports of all States that are party to the Charter.

\subsubsection{Conclusion on the African Commission on Human and Peoples' Rights}

The establishment of the African Commission was a big step towards the effective recognition of human rights within the African continent.

Taking into consideration the universal level, the establishment of Commissions which observes the realization of the human rights obligation is not exceptional: For instance, on the UN level, the Human Rights Council and the Human Rights Committee, as well as the High Commissioner for Human Rights (UNHCHR), was established to monitor the implementation of the obligations of the International Covenant on Civil and Political Rights. As mentioned before, the Intra-American system just as the African Union provides for a Commission which aims to ensure the effective protection of human rights. The Council of Europe in its first decades of existence also provided for a Commission with the similar aims.

The African Commission was the first institution that was mandated to ensure human rights protection on the African continent.

Despite the advantages coming along with the establishment of the Commission, the work of the Commission attracted much criticism. Many complaints submitted by individuals have been declared inadmissible or were concluded through lax settlements. Consequently, the Commission appears to be ineffective. ${ }^{277}$ Especially, one gets the impression that where decisions are too politically charged, they are postponed. ${ }^{278}$

Thus, in order to ensure better adherence, within the African Union, the Commission may try to speed up its decision-making process regarding the communications.

Besides that, the work of the Commission appears to lack transparency - to resolve this issue a full list of all communications should be published in the activity report on a regular basis. Thereupon, especially NGO's would have a detailed overview of decisions pending before the Commission. Last but not least, the organs of the African Union would need to ensure the final implementation of the communications in the affected AU Member States. ${ }^{279}$

\footnotetext{
277 Mangu (2004), 140.

278 Viljoen (2007), 415.

279 Killander (2012), 240.
} 
In order to improve the effectiveness of the Commission, more members should become elected. In comparison, the European Human Rights Commission was equipped with one member per Member State, whereas the African Commission provides for eleven members. Furthermore, the Commission remains quite ineffective due to the to the fact that the commissioners work only on a part-time basis. Similar to the African Court of Human and Peoples' Rights, at least the Chairman of the Commission should be working on a full-time basis. A permanent availability of the President and the Vice-President would improve work of the Commission. ${ }^{280}$

Apart from the issue of the slow decision-making process, many people around the continent lack awareness of the existence of the Commission. This, in turn, may be the reason for the low number of cases submitted. This issue may be resolved with better protective activities. ${ }^{281}$ Another reason for the low number of cases being submitted is the lack of financial resources representing a serious obstacle for many citizens.

Unlike individuals, NGOs are still not very active in bringing complaints before the Commission. Only a small number of NGOs are represented in the sessions of the Commission and out of it, a very little number submits reports to the Commission. On the one hand, it appears understandable that the majority of the NGOs only has limited resources and thus do not always have the possibilities to become active on the regional level. On the other hand, however, it is up to the NGOs to secure and to develop the potential of the Commission. Thus, NGOs need to promote the existence of the Commission among the continent, but also they should make use of the possibility to call attention to the Commission in case of human rights violations. ${ }^{282}$ Besides that the admissibility requirements for a complaint to be submitted are not without problems. Thus, a legal layman may have difficulties to submit a complaint before the Commission without legal assistance - which in many cases does exceed one's financial capacities. Therefore, many people may be prevented from submitting a complaint. On the other hand the strict requirements may be justified by the fact that the Commission only meets twice a year. Thus it has to protect itself from a flood of claims. Apart from the issue of the small number of complaints submitted to the Commission, the issue of effective remedies renders the Commission a weak institution. ${ }^{283}$ Hence, the Commission does not have the power to make binding decisions against parties that have violated human rights. The Commission can only make recommendations to the Assembly of Heads of State of Governments. Even the publications of the Commission of violations need to be approved by the Assembly of Heads of State and Government, which constitute a political body. In this context, a former Commissioner called the members of

\footnotetext{
280 Umozurike (2007), 188 et seq.

281 C. Heyns, 'Some Thoughts on Challenges Facing the International Protection of Human Rights in Africa Column', 27 Neth Q Hum Rts (2009), 447.

282 Viljoen (2007), 417.

283 Mindizie (2008), 209 et seq.
} 
the Assembly of Heads of State and Government to be 'very guilty parties' . ${ }^{284}$ Thus, the effective implementations of the recommendations issued by the Commission depend on massive political pressure.

In contrast to the African Commission, the Inter-American Commission is far more proactive in its actions and thus more recognized by civilians, even though the functioning in general of both Commissions is quite similar. However, the Inter-American Commission employs its fact-finding competences much more intensively than the African Commission. Furthermore, the findings of the Inter-American Commission are much more extensive in content. Finally, the communications mechanism of the African Commission, in contrast to the Inter-American Commission is confidential and consequently the African Commission enjoys much less visibility than the American Commission. ${ }^{285}$ Similar to the African Commission, the American system and also the former European system require the exhaustion of domestic remedies. ${ }^{286}$

\subsubsection{The African Court on Human and Peoples' Rights}

Apart from the Commission, the African Court of Human and Peoples' Rights was established in order to ensure the effective implementation of the provisions guaranteed in the African Charter.

Since the African Commission - as explained above - is a quasi-judicial institution, the establishment of the Court brought about much hope for an effective human rights protection. ${ }^{287}$

Until the establishment of the Court, the African regional system - in comparison to the European and African system - did not provide for a judicial institution. ${ }^{288}$

284 Ex-Commissioner M. Mokama in C. Odinkalu, Interview with Moleleki Mokama (1992).

285 R. Bonello, Comparative View - The Inter-American Commission of Human Rights and the African Commission of Human and Peoples, (unpublished) available at: https://www.academia. edu/21827648/Comparative_View_The_Inter_American_Commission_of_Human_Rights_ and_the_African_Commission_of_Human_and_Peoples, (last visited: 20 March 2017).

286 Okere (1984), 157.

287 M. Bortfeld, Der Afrikanische Gerichtshof für Menschenrechte - Eine Untersuchung des Zusatzprotokolls zur Afrikanischen Charta für die Menschenrechte und die Rechte der Völker (2004), 89.

288 J. Mubangizi \& A. O’Shea, 'African Court on Human and Peoples' Rights, Notes and Comments', 24 S Afr YB Int'l L (1999), 256. 


\section{a) History and establishment of the African Court of Human and Peoples" Rights}

The vision of the establishment of an African Court with jurisdiction on human rights first came up in 1961, at the 'Conference on the Rule of Law'289 in Lagos, Nigeria. During the conference, African jurists that participated at this conference urged African governments to consider the possibility of adopting an African Convention on Human Rights' and the creation of a court of appropriate jurisdiction'. ${ }^{290}$

The OAU Charter, which was adopted two years later, did not, however, provide for a jurisdictional instrument. ${ }^{291}$ The possibility of the implementation of human rights instruments again came up during the consultancies, which lead to the adoption of the African Charter in 1981. The proposal of Keba M'Baye ${ }^{292}$ in this context stated that the installation of such a court should be deferred to the future and that it should be established through a Protocol to the Charter. ${ }^{293}$ In addition, the creation of a tribunal tasked with judging on crimes against humanity as well as the protection of human rights was considered by Guinea in 1979. ${ }^{294}$

Finally, with the end of the Cold War, when the protection of the rule of law worldwide experienced a great boost, the OAU Assembly, during its Ordinary Session in Tunis in 1994, mandated the Secretary General of the OAU to organize a meeting of experts to discuss on the Establishment of the African Court on Human and Peoples' Rights. ${ }^{295}$

Hence, in 1995, several lawyers met in Cape Town in order to issue the first draft protocol. This draft protocol emphasized the possibility of direct access to the Court for individuals. After the presentation of the draft to the OAU Council of Ministers, it was amended during the second meeting in 1997. The proposal was changed regarding the following concerns: first, the number of ratifications for the Protocol to enter into force was increased from 11 to 15 . Secondly, the accessibility of the Court by individuals became limited, since their access to the Court needs to be approved through the respective State. The third meeting of government legal experts and diplomats took place in Addis Ababa, Ethiopia for further clarification.

\footnotetext{
289 The International Commission of Jurists in 1961 sponsored a conference on the Rule of Law in Lagos, Nigeria, where a resolution entitled the "Law of Lagos" was accepted, see Viljoen (2007), 420 et seq.

290 Viljoen (2007), 411 et seq.

291 See Art VII of the 1963 Charter of the Organisation of African Unity.

292 Keba M'Baye was a senegales lawyer, who served to several courts in Senegal, such as the Supreme Cour and who raised the right to development; see: Kéba M’Bayes Arbeitspapier über das Recht der Entwicklung; available at: https://www.geschichte-menschenrechte.de/recht-aufentwicklung/?type $=98765$ (last visited: 14 August 2020).

293 Muigai (2012), 271.

294 R. J. V. Cole, 'The African Court on Human and Peoples' Rights: Will Political Stereotypes form an Obstacle to the Enforcement of its Decisions?', 42 Comp \& Int'LJ S Afr 1 (2010), 23.

295 Mubangizi \& O'Shea (1999), 257 et seq.
} 
Following the acceptance of the amendments the Protocol was presented to the Conference of Ministers of Justice and Attorneys-General. Finally, the protocol was sent to the OAU Assembly to be then approved in Ouagadougou, Burkina Faso. ${ }^{296}$

The Court finally became operative on 25 January 2004 upon receipt of the 15th ratification. In July 2006, the Assembly decided that the seat of the Court shall be located in Arusha, Tanzania. ${ }^{297}$ In 2008, the Protocol was ratified by 23 Member States of the African Union. The Court issued its first ruling on 15 December 2009 in the matter Michelot Yogogombaye v. Republic of Senegal. ${ }^{298}$

\section{b) The functioning of the African Court of Human and Peoples' Rights}

Similarly to most international institutions, the African Court on Human and Peoples' Rights provides for a Protocol regulating its internal procedure, such as the composition, and the mandate.

\section{aa) The Composition of the African Court on Human and Peoples' Rights}

The composition of the Court is set-out in Arts. 12-14 of the Protocol on the African Court on Human and Peoples' Rights. The Court consists of eleven judges that are elected for a six-year term, once renewable. ${ }^{299}$ In contrast to the European human rights system, not each country is represented in the Court. ${ }^{300}$ The judges are elected among 'jurists of high moral character and of recognized practical, judicial and academic competence and experience in the field of human rights. ${ }^{301}$ In accordance with Art. 12(1) of the Protocol, every Member State who has ratified the Protocol has the right to propose three candidates, of which two need to be citizens of the respective State. This system is similar to the Inter-American system. ${ }^{302}$ Legal expertise constitutes a minimum requirement in order to become a member of the

\footnotetext{
296 Viljoen (2007), 421.

297 I. Kane \& A. Motala, 'The Creation of a New African Court of Justice and Human Rights' in M. Evans \& R. Murray (eds), The African Charter on Human and Peoples' Rights - The System in Practice, 1986-2006 (2008), 407.

298 In the case Michelot Yogogombaye v. Republic of Senegal (Application No. 001/08), Judgment of 15 December 2009, the Court concluded that it had no jurisdiction on the case in which the applicant requested the suspension of the proceedings brought in Senegal against Hissène Habré, the former Head of State of Chad. The Court dismissed the claim because Senegal did not enter a declaration accepting the jurisdiction of the Court to hear individual petitions as required under Art. 34(6) of the 1998 Protocol Establishing the African Court on Human and Peoples' Rights, para 46.

299 Mangu (2004), 156.

300 Viljoen (2007), 431.

301 See: Art. 11(1) of the 1998 Protocol to the African Charter on Human and Peoples' Rights on the Establishment of the African Court on Human and Peoples' Rights; see also: Eze (2009), 245.

302 Bortfeld (2004), 99.
} 
Court. ${ }^{303}$ Art. 18 of the Protocol furthermore stipulates that 'the position of judge of the Court is incompatible with any activity that might interfere with the independence or impartiality of such a judge or demands of the office'. The respective judge may be re-elected once for another two years. ${ }^{304}$ The list of the names of the judges needs to be submitted to the Court 30 days before its next session. ${ }^{305}$

In order to represent the geographic order of the African continent, no more than one judge of the same country may be elected. ${ }^{306}$ Moreover, a balanced representation of the geographic main regions within the African continent, as well as the principal legal traditions needs to be taken into consideration when electing the judges. ${ }^{307}$ The judge remains in office until being replaced by a newly-elected judge. If the date is scheduled and a case is pending at that time and was subject of a hearing, the judge remains in his or her position until its completion. ${ }^{308}$ The judges - with exception to the President - serve on a part-time basis. The Assembly is entitled to change this condition if it appears necessary. ${ }^{309}$

After the election of the respective judges, the judges themselves elect the President and Vice-President. However, solely the President stays at the seat of the Court and serves on a full-time basis. ${ }^{310}$

During its third session, the Court decided to hold two ordinary sessions annually. ${ }^{311}$

\section{bb) The Rules of Procedure of the African Court on Human Peoples' Rights}

On account of the provisions made in the Protocol on the African Court on Human and Peoples' Rights, the Court is required to create its own rules of procedures, in harmony with the provisions of the procedures of the Commissions. This requirement leads to the need for intensive communications between both institutions. ${ }^{312}$

\footnotetext{
303 See: Art. 11(1) of the 1998 Protocol to the African Charter on Human and Peoples' Rights on the Establishment of an African Court on Human and Peoples' Rights.

304 See: Art. 21(2). of the 1998 Protocol to the African Charter on Human and Peoples' Rights on the Establishment of an African Court on Human and Peoples' Rights.

305 See: Art. 13(2) of the 1998 Protocol to the African Charter on Human and Peoples' Rights on the Establishment of an African Court on Human and Peoples' Rights.

306 See: Art. 11(2) of the 1998 Protocol to the African Charter on Human and Peoples' Rights on the Establishment of an African Court on Human and Peoples' Rights.

307 See: Art. 14(2) of the 1998 Protocol to the African Charter on Human and Peoples' Rights on the Establishment of an African Court on Human and Peoples' Rights.

308 See: Art. 2 of the 1998 Protocol to the African Charter on Human and Peoples' Rights on the Establishment of an African Court on Human and Peoples' Rights.

309 Mangu (2004), 157.

310 See: Art. 12(1) of the 2008 Rules of Court - African Court of Human and Peoples' Rights.

311 See: Art. 13(2) of the 1998 Protocol to the African Charter on Human and Peoples' Rights on the Establishment of an African Court on Human and Peoples' Rights.

312 See: Art. 33 of the 1998 Protocol to the African Charter on Human and Peoples' Rights on the Establishment of an African Court on Human and Peoples' Rights; See also: Viljoen (2007), 452.
} 
The first set of rules - so-called Interim Rules of the Court - came into effect on 20 June 2008. As a result of the joint meetings between the Court and the Commission, the rules were replaced by a new set on 2 June 2010 and came into force with immediate effect.

The rules schedule that the Court shall hold four ordinary sessions within a year. Each session shall last about fifteen days. If necessary, the President or the majority of the judges may call for an extraordinary session. Furthermore, the rules state that the proceedings of the Court can be in written or oral form. Written procedures generally consist of applications, statements regarding the case, observations, defenses, and replies. Oral procedures generally include the hearing by the Court of the involved parties, witnesses or experts. ${ }^{313}$

In accordance with the Protocol, seven judges form a quorum in order to hear the case and to deliberate. Within 90 days after the end of the deliberations, the Court has to issue a judgment. ${ }^{314}$ This wording, however, leaves room for a broad interpretation for the judges and thus the process may take a long time. The postponing of deliberations should only take place in exceptional cases. ${ }^{315}$

Regarding the execution of the judgments issued by the Court, the 'States parties to the present Protocol undertake to comply with the judgment in any case to which they are parties within the time stipulated by the Court and to guarantee its execution. ${ }^{3} 316$

\section{c) The Mandate of the African Court on Human and Peoples' Rights}

The African Court on Human and Peoples' Rights is entitled to 'complement the protective mandate of the African Commission on Human and Peoples' rights [...] conferred upon it by the African Charter on Human and Peoples' Rights. ${ }^{317}$

According to Arts. 3 and 7 of the Protocol on African Court on Human and Peoples' Rights, the Court is enabled to decide on disputes against a State Party to the Protocol that is impeached of the breach of the African Charter or other ratified human rights instruments. Art. 3(1) stipulates that the jurisdiction of the Court

313 Muigai (2012), 275 et seq.

314 See: Arts. 23 and 28 of the 1998 Protocol to the African Charter on Human and Peoples' Rights on the Establishment of an African Court on Human and Peoples' Rights. In accordance with Art. 22 a judge national to an involved State shall not hear the case. This provision differs from the nomination of ad hoc judges from involved States under Art. 31 of the ICJ statute.

315 Viljoen (2007), 452.

316 See: Art. 30 of the 1998 Protocol to the African Charter on Human and Peoples' Rights on the Establishment of an African Court on Human and Peoples' Rights.

317 See: Art. 2 of the 1998 Protocol to the African Charter on Human and Peoples' Rights on the Establishment of an African Court on Human and Peoples' Rights. 
shall broaden to 'all cases and disputes submitted to it concerning the interpretation and application of the Charter, this Protocol and any other relevant human rights instrument ${ }^{318}$ ratified by the States concerned.'

Taking into consideration this article together with Art. 7 of the Charter, the impression arises that the jurisdiction of the Court is much wider than other regional human rights courts ${ }^{319} \cdot{ }^{320}$ For instance, the jurisdiction of the European Court on Human Rights is much more limited, since the application and interpretation is limited to their governing protocols and conventions. ${ }^{321}$

Since only African Union Member States are able to sign this Protocol, it becomes clear that the Court does not have jurisdiction against a State, which is not member of the AU due to, for example, being suspended for its internal political conflicts. ${ }^{322}$

Lately, the Court made use of its broad mandate and thus the Court just delivered its first decision ${ }^{323}$ involving the Protocol to the African Charter on the Rights of Women. In this case, two Malian NGOs claimed before the Court that the Malian Persons and Family Code of 1962 was in breach of several international treaties as it set the minimum age for females to enter into a marriage to 16 . It is remarkable that the Court did not refer to the African Charter at all in its judgment but rather to other treaties such as the Protocol to the African Charter on the Rights of Women. This may evoke the impression that the Court is ready to include international treaties other than the African Charter in its jurisdiction. ${ }^{324}$

318 As consequence, the Court enjoys jurisdiction on a broad spectrum of human right instruments e.g.: The International Covenant on Civil and Political Rights, the International Covenant on Social, Cultural and Economic Rights; the Convention on the Elimination of All Forms of Discrimination; the Convention on the Elimination of All Forms of Discrimination Against Women; the Torture Convention; the Genocide Convention; the Convention on the Rights of the Child, (see: Viljoen (2007), 444 et seq).

319 For instance, the jurisdiction of the European Court of Human Rights and the Inter-American Court of Human Rights is limited to the human rights instruments of which they were created; see: S. T. Ebobrah 'International Human Rights Courts', in Romano et al (eds), The Oxford Handbook of International Adjudication (2013).

320 Ndulo (2008), 183.

321 Cole (2010), 27.

322 M. Ssenyonjo, 'Direct Access to the African Court on Human and Peoples' Rights by Individuals and Non-Governmental Organisations: An Overview of the Emerging Jurisprudence of the African Court 2008-2012', 2 Int'l Hum Rts L Rev (2013), 17, 19.

323 Association pour le progres et la Defénse des Droits de Femmes Maliennes and the Institute for Human Rights and Developments v. the Republic Mali, Application No. 046/2016, Judgment of 11 May 2018.

324 T. Davi, 'African Court on Human and Peoples' Rights Delivers Landmark Ruling on Women's Rights and the Rights of the Child in Mali', EJIL:Talk! (27 July 2018), available at: https://www. ejiltalk.org/african-court-on-human-and-peoples-rights-delivers-landmark-ruling-on-womensrights-and-the-rights-of-the-child-in-mali/, (last visited: 5 September 2018). 
In addition, Art. 4(1) of the Protocol empowers the African Court on Human and Peoples' Rights 'to give advisory opinion on any legal matter relating to the Charter or any other relevant human rights instrument ratified by the State' if a Member State, the AU or its organs or an African Organization being recognized by the AU requests such an opinion.

Since the Court exercises direct jurisdiction on all human rights instruments being 'ratified by theStates concerned', it has jurisdiction on almostall 'regional, sub-regional, bilateral and multilateral and international treaties. ${ }^{325}$ Thus, the affected individual can refer to other international human rights treaties being ratified by the State in question. Therefore, depending on the interpretation of its mandate, the Court is expected to make use of other international legal resources set up by other regional and international mechanisms such as the UN Declaration on the Rights of Indigenous Peoples and the UN Declaration on the Rights of Minorities. ${ }^{326}$

Art. 2 of the Protocol stipulates that the decisions being issued by the Court are of binding character for all States that ratified the Protocol.

The Court is mandated, to 'consider cases or transfer cases to the Commission, but its decisions on the admissibility will be based on Art. 56 of the Charter, which means that it will be guided by the practice of the Commission as explained above'. ${ }^{327}$

If the Court finds that human rights are violated, it may order an adequate remedy in favor of the party being violated in its rights. The remedy can either consist of reparation or compensation..$^{328}$

Furthermore, 'any African organ' that is recognized by the AU may submit requests in order to receive advisory opinions of the Court. Thus, NGOs that are recognized by the $\mathrm{AU}$ are able to seek such advisory opinions of the Court. ${ }^{329}$

In contrast to the UN Charter, the provisions of the Protocol to the African Court in this regard are more open as compared to the UN Charter, which only allows the Security Council and the General Assembly to request an advisory opinion of the International Court of Justice. ${ }^{330}$ Furthermore, under the provisions of Art. 96(2) specialized agencies within the UN, which however need authorization by the General Assembly may further request for an advisory opinion of the Court.

\footnotetext{
325 Ndulo (2008), 195.

326 Swart (2013), 444.

327 See. Art. 6 of the 1998 Protocol to the African Charter on Human and Peoples' Rights on the Establishment of an African Court on Human and Peoples' Rights; see also: C. Beyani, Protection of the Right to Seek and Obtain Asylum under the African Human Rights System (2013), 67.

328 Viljoen \& Baimu (2004), 250.

329 Cole (2010), 29.

330 See: Art. 96(1) of the Charter of the United Nations, see also: Mangu (2004), 158.
} 
aa) Access of individuals to the African Court on Human and Peoples' Rights

Regional Courts often provide limitations with regard to the access of individuals to the Courts.

Art. 5(1) of the Protocol points to four categories of claimants that can directly access the Court - the Commission, a State Party against which the claim is settled, a State Party where a citizens' human right may be violated and a State Party that lodged a claim to the Commission. Art. 5(3), as well as Art. 34(6) of the Protocol ensure the appearance of individuals and NGOs, which have an observer status before the Commission. ${ }^{331}$

Art. 34(6) provides in that regard:

$[\mathrm{A}] \mathrm{t}$ the time of the ratification of this protocol or any time hereafter, the State shall make a declaration accepting the competence of the Court to receive cases under article 5(3) of this Protocol. The Court shall not receive any petition under article 5(3) involving a State Party which has not made such a declaration.

Art. 5(3) of the Protocol states that the Court 'may entitle Non-Governmental Organisations (NGOs) with observer status before the Commission and individuals to institute cases directly before it, in accordance with article 34(6) of this Protocol.' Thus, for an individual to be able to submit a case before the Court, the respective country of origin or country involved needs to submit a declaration to the Court, stating that it allows the Court to hear cases from its citizens. This principle was again approved in the first case ${ }^{332}$ of the Court. ${ }^{333}$ In December 2009 the Court found, that 'the effect of Arts. 5(3) and 34(6) of the Protocol, read together, is that direct access to the Court by an individual is subject to the deposit by the respondent State of a special declaration authorizing such case to be brought before the Court.' ${ }^{334}$ The word 'shall' in Art. 34(6) in this context shows that the submission of such declaration by a Member State is optional. ${ }^{335}$

According to this provision, only citizens of those States which have ratified the Protocol and provided the special declaration, can expect to be protected by the Court. As of now 30 States have ratified the Protocol of the Court and out of those 30 States, only 8 States declared that individuals may submit cases to the Court. These 8 States are Benin, Burkina Faso, Côte d'Ivoire, Ghana, Mali, Malawi, Tanzania and Tunisia. ${ }^{336}$ As a consequence, individuals, struggling with the criteria of Art. 56 of the African Charter may not receive any legal protection on the level

\footnotetext{
331 Mangu (2004), 158.

332 See: Michelot Yogogombaye v. the Republic of Senegal, Application 001/2008, Judgment of 5 December 2009.

333 See: ibid., para 37.

334 Ssenyonjo (2013), 28.

335 See: Michelot Yogogombaye v. The Republic of Senegal, para 29.

336 Official Website of the African Court of Human and Peoples' Rights: available at: http://www. african-court.org/en/, (last visited: 12 September 2018).
} 
of the African Union. ${ }^{337}$ This principle was again approved in the first case ${ }^{338}$ of the Court. ${ }^{339}$ In December 2009 the Court decided, that 'the effect of Arts. 5(3) and 34(6) of the Protocol, read together, is that direct access to the Court by an individual is subject to the deposit by the respondent State of a special declaration authorizing such case to be brought before the Court.' 340

The Protocol does not indicate, that only the victim of human rights violation itself may submit a case to the Court. Thus, also indirect or potential victims of human rights violations may be able to refer cases to the Court. In contrast to the Protocol, Art. 33 of the European Convention as well as Art. 44 of the American Convention generally indicate the so-called victim-requirement. ${ }^{341}$

Furthermore, the Court lacks jurisdiction over Intra-Governmental Organizations such as the African Union ${ }^{342}$ and its institutions. ${ }^{343}$ This principle was approved by the Court in Femi Falana v. African Union, ${ }^{344}$ a case where a Nigerian lawyer claimed against the African Union. He stated that the current version of Art. 34(6) of the Protocol to the African Court violates human rights, such as the right to a hearing. He further argued that due to this requirement, he couldn't be heard before the African Court of Human Rights since Nigeria did not make a declaration in accordance to Art. 34(6). Thus, he argued that Art. 34(6) of the Protocol is 'illegal, null and void'.

In its decision, the Court found that due to the provisions of Arts. 5(3) and $34(6)$ of the Protocol, it is not competent to hear the case. The further Court reasoned - in line with Art. 34 VCLT - that where an international organization is not party to a treaty or protocol it cannot be sued before the Court. However, the judges

337 Art. 56 sets out the following requirements: Communications relating to Human and Peoples' rights referred to in Art. 55 received by the Commission, shall be considered if they:

Indicate their authors even if the latter requests anonymity,

Are compatible with the Charter of the Organisation of African Unity or with the present Charter, Are not written in disparaging or insulting language directed against the State concerned and its institutions or to the Organisation of African Unity,

Are not based exclusively on news disseminated through the mass media,

Are sent after exhausting local remedies, if any, unless it is obvious that this procedure is unduly prolonged,

Are submitted within a reasonable period from the time local remedies are exhausted or from the date the Commission is seized with the matter, and

Do not deal with cases which have been settled by those States involved in accordance with the principles of the Charter of the United Nations, or the Charter of the Organisation of African Unity or the provisions of the present Charter.

338 See: Michaelot Yogogombaye v. the Republic of Senegal.

339 Ibid., para 37.

340 Ssenyonjo (2013), 28.

341 Viljoen (2007), 443.

342 See: Femi Falana v. African Union, Application No. 001/2011, Judgment of 26 June 2012, paras 9-12 and 6-8.

343 See: Efoua Mbozoo Samuel v. The Pan African Parliament, Application No. 010/2011, Judgment of 30 September 2011.

344 Femi Falana v. African Union, Application No. 001/2011, Judgment of 26 June 2012. 
also argued in these findings that Art. 34(6) of the Protocol is not in consistency with those of Arts. 1, 2, 7, 26, and 66 of the African Charter. The judges further found, that the Charter has a higher standing than the Protocol to the African Court. Therefore, Art. 34(6) of the Protocol, denying direct access to the Court by individuals without the submission of a declaration is in violation of the African Charter. ${ }^{345}$

However, the general modus operandi is the submission of a case to the Commission by an individual or an NGO. ${ }^{346}$ The Commission then submits those cases which are of great significance regarding the violation of human rights to the Court.

This competence of the Commission to submit cases involving a claim of individuals is of great importance in the African human rights systems. If a case involves human rights violation, the Commission may exercise pressure on the Court and in many situations the Court may not have any other choice than to confirm the decisions of the Commission. Thus, in the end, the Court may transform the conclusions of the Commission into convictions of the State party involved that are legally binding. ${ }^{347}$

Due to the requirements under Arts. 34(6) and 5(2) many cases already have been rejected by the Court. A good example is illustrated by the two applications brought before the Court against the Republic of South Africa in 2012, namely the Delta International Investments and other $v$. The Republic of South Africa and Emmanuel Joseph Uko and Others $v$ The Republic of South Africa. ${ }^{348}$

Delta International Investments brought the first claim to the Court alleging the violation of their rights to dignity, property, information, privacy, and non-discrimination as guaranteed by the Constitution of South Africa and the South African Charter.

At the time of the claim, South Africa did not issue the declaration according to the provisions of Art. 34(6). Consequently, the Court decided that it lacks jurisdiction to hear the cases against South Africa. Even though the violation was serious, the Court did not provide any notifications to forward the case to the African Commission in accordance with Art. 6(3) of the Protocol of the Court. ${ }^{349}$

\footnotetext{
345 Nmehielle (2013), 330.

346 See: Soufiane Ababou v. People's Democratic Republic of Algeria, Application No. 02/2011, Judgment of 20 October 2016.

347 A. P. van der Mei, 'The advisory jurisdiction of the African Court on Human and Peoples' Rights', 5 Afr Hum Rts LJ (2005), 27, 29.

348 Delta International Investments and others v. The Republic of South Africa, Application No. 002/2012, Judgment of 30 March 2012 and Emmanuel Joseph Uko and Others v. The Republic of South Africa, Application No. 004/2012, Judgment of 30 March 2012

349 Ssenyonjo (2013), 35.
} 
In the second claim, Emmanuel Joseph Uko v. The Republic of South Africa, ${ }^{350}$ a Nigerian national brought a petition against South Africa claiming on his behalf and on behalf of his family residing in South Africa, several human violations. Similar to the first case, the Court decided that 'pursuant to Arts. 5(3) and 34(6) of the Protocol, it manifestly lacks jurisdiction to receive the Application submitted by Emmanuel Joseph Uko and Others against the Republic of South Africa.' Again, the Court did not make any further comments regarding the possibility to forward of the case to the African Commission in accordance with Art. 6(3) of the Protocol. ${ }^{351}$

In the case of Baghadadi Ali Mahmouid $v$. The Republic of Tunisia, ${ }^{352}$ the claimant specifically asked for the implementation of provisional measures. However, taking into consideration Arts. 5(3) and 34(6) of the Protocol, the Court found that it lacks jurisdiction to receive the application. The Court misinterpreted Art. 27(2) of the Protocol, which in cases of extreme urgency and gravity and to avoid irreparable harm to persons, allow the Court to implement provisional measures. Without giving any reason for its actions, the Court did not refer the case to the Commission.

There are, however, some cases which have been transferred to the Commission under Art. 6(3), including Daniel Amare and Mulugeta Amare v. Republic of Mozambique \& Mozambique Airlines, ${ }^{353}$ Soufiane Ababou v. People's Democratic Republic of Algeria, ${ }^{354}$ and Ekollo M. Alexandre v. Republic of Cameroon and Federal Republic of Nigeria. ${ }^{355}$ In these cases the Court did not specify the reasons for the transfer to the Commission and only stated that the cases were 'appropriate' to be transferred to the Commission. A detailed justification is, however, necessary to ensure the consistency and predictability of the decisions of the Court. ${ }^{356}$

Aside from the African Court on Human and Peoples' Rights, the European and American Courts were quite hesitant regarding the direct access of individuals to the respective Courts.

On the European level, the Commission initially allowed individual complainants on a discretionary basis to be 'assistants' to the lawyers of the Commission. In its first case, the European Court of Human Rights concluded that the Commission should present the case to the Court. ${ }^{357}$ About ten years later, the Court found that the lawyers of the applicant should act as assistant to the delegates of the Commis-

350 Emmanuel Joseph Uko v. The Republic of South Africa, Application No. 004/2012, Judgment of 13 March 2012.

351 Ssenyonjo (2013), 35.

352 Baghadadi Ali Mahmouid v. The Republic of Tunisia, Application No. 007/2012, Judgment of 26 June 2012.

353 Daniel Amare and Mulugeta Amare v. Republic of Mozambique \& Mozambique Airlines, Application No. 002/2011, Judgment of 16 June 2011.

354 Soufiane Ababou v. People’s Democratic Republic of Algeria, Application No. 005/2011, Judgment of June 2011.

355 Ekollo M. Alexandre v. Republic of Cameroon and Federal Republic of Nigeria, Application No. 008/2011, Judgment of 23 September 2011.

356 Ssenyonjo (2013), 40.

357 See: Lawless v. Ireland, Case No. 3, [1961] ECHR 2, para 6. 
sion. ${ }^{358}$ In accordance with the amended Rules of the European Court, which came into effect in 1983, the Commission was obliged to invite [the applicants] to be represented at the hearing in their own right'. ${ }^{359}$ Finally in 1998, with the adoption of Protocol 11 and in accordance with Rules 30(1) and 33(3)(d,) individuals and NGOs were granted direct access to the European Court of Human Rights.

The Inter-American Human Rights Court adopted a similar rule, where the lawyer of the applicant was able to be part of the legal team of the Commission in order to present the arguments of the applicant to the Court. Due to an amendment in 1996, the applicant was allowed to give his arguments during the phase of reparations, ${ }^{360}$ but was not able to participate during the proceedings of the Court. ${ }^{361}$

Thus, the access of individuals to the African Court on Human and Peoples' Rights is dependent on the political will of the leaders. As long as they do not submit a declaration allowing the success of individuals to the Court, many people within the continent will not be provided an effective protection against human rights violations at a regional level. Moreover, governments need to ensure that people are aware of the existence and work of the Court.

bb) Access of NGOs to the African Court on Human and Peoples' Rights

NGOs on every continent are of high importance for the protection of human rights. Their access to the African Court on Human and Peoples' Rights is an important feature of the effective implementation of such rights.

Art. 5(3) of the Protocol to the Court further states that only NGOs provided with an observer status before the Commission are eligible to submit cases before the African Court. Even though the Commission, in general, does not reject applications for the observer status as long as the requirements are met, in 2017, only 477 NGOs possessed such status. NGOs which do not do so are excluded from directly submitting cases before the Court. Thus, NGOs may not submit cases to the Court, even though the State filed a declaration in accordance with Art. 34(6) of the Protocol. Therefore, especially NGOs that work on matters of discrimination due to sexual orientation may not meet the criteria of the Commission. ${ }^{362}$ Currently, the requirements are as follows:

All organisations applying for observer status with the African Commission shall consequently:

(a) Have objectives and activities in consonance with the fundamental principles and objectives enunciated in the OAU Charter [the Constitutive Act

\footnotetext{
358 See: De Wilde, Oms and Versyp v. Belgium, Application No. 2832/66, 2899/66, 2835/66, (1970) 1 EHRR 373, para 8.

359 Viljoen (2007), 450.

360 See: Rule 23 of the 2013 Rules of Procedure of the Inter-American Court.

361 Viljoen (2007), 450.

362 Ssenyonjo (2013), 42
} 
of the African Union] and in the African Charter on Human and Peoples' Rights;

(b) Be organisations working in the field of human rights;

(c) Declare their financial resources. ${ }^{363}$

For instance, the Coalition of African Lesbians was not granted observer status 'because the activities of the said Organisation do not promote and protect any of the rights enshrined in the African Charter ${ }^{1364}$ This decision can be explained by the fact that most African States do not accept same-sex relation due to religious and cultural reasons.

However, every African organization recognized by the AU, in accordance with Art. 4 of the Protocol of the Court, may receive an advisory opinion by the Court. Such advisory opinions, however, are not legally binding. ${ }^{365}$ The term African organization - in comparison to the term used with regards to the African Commission is a narrower group: it includes NGOs with observer status and it provides that they have to be African, meaning that e.g. their headquarters should not be outside Africa. ${ }^{366}$

Therefore, those NGO's that are qualified for access may have an important role to play in the future. However, financial issues need to be resolved for the NGOs to be able to meet such expectations. Most NGOs do not even appear in the sessions of the African Commission - even though they have the right to - because of the lack of funding. Therefore, it is unlikely that many NGOs are capable to submit many cases to the Court.

\section{d) Relation of the Court to the African Commission on Human and Peoples' Rights}

The African Court was set up with the aim of supporting the African Commission on Human and Peoples' Rights requiring a structured cooperation between both institutions.

Art. 2 of the Protocol of the Court points out the relation between the Commission and the Court, stating the the Court shall bear in mind the provisions of this Protocol, complement the protective mandate of the African Commission on Human and Peoples' Rights [...]'. Furthermore, the Preamble of the Protocol states that the Court is intended to '[c]omplement and reinforce the functions of the African Commission.'

363 See: Art. 2 of the 1999 Resolution of the African Commission on the criteria for granting and enjoying observer status to non-governmental organizations working in the field of human rights with the African Commission. See: 28th Activity Report (2009-2010), EX.CL/600 (XVII), para 33.

365 Ssenyonjo (2013), 47.

366 Viljoen (2007), 455. 
Many voices declared that after its establishment, the Court took over the whole protective mandate provided by the Charter, while the Commission focused on the promotion of the protected rights. ${ }^{367}$

The main reason for the establishment of the African Court on Human and Peoples' Rights was the fact that many African States simply ignored the decisions being issued by the Commission. In order to make use of the role of the newly created Court, whose decisions have a binding character, the Commission amended its rules of procedure and inter alia added Rule 118 (1) which states:

If the Commission has taken a decision with respect to a communication submitted under Arts. 48, 49 or 55 of the ACHPR and considers that the State has not complied or is unwilling to comply with its recommendations in respect of the communication within the period stated in Rule 112(2), it may submit the communication to the Court pursuant to Art. 5(1)(a) of the Protocol and inform the parties accordingly.

Furthermore, the Commission may transfer a case to the African Court, if the respondent State does not comply with the provisional measures. On basis of its rules of procedure, the Commission may raise those measures to prevent irreparable damages due to human rights violations. Lastly, cases may be submitted to the Court by the Commission if gross human rights violations are suspected of having occurred. ${ }^{368}$

Once the Commission transferred the case to the Court, the Commission 'becomes a conduit through which the parties to the initial communication reach the Court. ${ }^{369}$ The Commission which submitted the case to the Court - according to the Rules of the Commission - becomes party to the case. ${ }^{370}$ Additionally, the individual remains a party to the case even though the Commission transferred it to the Court. ${ }^{371}$

Due to the restrictions made by the African Court to be accessed by individuals, ${ }^{372}$ the Commission remains the only institution within regional level for individuals (whose States did not accord them direct access to the Court through an explicit decision) to call attention to a possible violation of human rights. ${ }^{373}$ Thus, if a case first went through the Commission, it should be ensured that the Court does not make use of the doctrine of res judicata with regard to such a case. ${ }^{374}$

367 M. Mutua, 'The African Human Rights Court: A Two-Legged Stool?', 21 Hum Rts Qrt 2 (1999), 342, 344.

368 A. J. Ali, 'The Admissibility of Subregional Courts' Decisions before the African Commission or African Court', 6 Mizan L Rev 2 (2012), 261.

369 Murray \& Long (2015), 156.

370 Rule 120 of the 2010 Rules of Procedure of the African Commission on Human and Peoples' Rights.

371 Murray \& Long (2015), 146.

372 Viljoen (2007), 449.

373 Mutua (1999), 355.

374 Viljoen (2007), 437. 
If the Commission becomes a party to a case before the African Court, it still needs to express its own views on the case. It may not simply report again what the parties have said before the Commission. This requirement raises financial issues since the Rules of Procedure require that the Commission be represented before the Court by 'one or more Legal Officers' of the Secretariat and/or or experts.' 375

Until 2013, the Commission transferred four cases after ruling that it lacked jurisdiction to deal with them. The cases were Soufiane Ababou v. People's Democratic Republic of Algeria ${ }^{376}$, Daniel Amare and Mulugeta Amare v. Republic of Mozambique and Mozambique Airlines ${ }^{377}$, Ekolli Moundi Alexandre v. Nigeria and Cameroon and Association Juristes d'Afrique pour la Bonne Governance v. République de Côte d'Ivoire $^{378}$. In all cases, the involved States did not submit the declaration under Art. 34(6). In the last case, the Court additionally argued that the Commission did not have the observer status as required under the provisions of Art. 5 of the Protocol. In 2016, the Court however declared a case, ${ }^{379}$ forwarded by the Commission, to be admissible. The case involved indigenous people. The Court ruled that the government of Kenya violated the rights of the Manu Ogiek People through the eviction from their ancestral land. The Court found that these actions would be in violation of Arts. 1, 2, 8, 14, 17 and 22 of the African Charter. The effective implementation of the ruling is, however, questionable since the government of Kenya still needs to implement another ruling from 2009. The judgment however gives hope to all indigenous people across the continent, who own lots of land which does not only consist of farms but also of forests. ${ }^{380}$

As Rule 118 does not outline explicitly the relation between the two institutions, the Commission, needs to submit cases strategically, in order to not be criticized for the abuse of the Court as an enforcement mechanism. ${ }^{381}$

A development similar to the European Union will most likely take place in the future - the European human rights mechanism developed itself from a twotiered system which consisted of a Commission and a Court. This system developed into a single Court, the European Court of Human Rights, which is now based in

375 See: Art. 29 No. 3(b) of the 2010 Rules of Court - African Court on Human and Peoples' Rights.

376 Soufiane Ababou v. Peoples' Democratic Republic of Algeria, Application No. 002/2011, Judgment of 16 June 2011.

377 Daniel Amare and Mulugeta Amare v. Republic of Mozambique and Mozambiqe Airlines, Application No. 005/2011, Judgment of 16 June 2011.

378 Cameroon and Association Juristes d'Afrique pour la Bonne Governance v. République de Côte d'Ivoire, Application No. 006/2011, Judgment of 16 June 2011.

379 African Commission on Human and Peoples' Rights v. Republic of Kenya, Application No. 006/2012, Judgment of 26 May 2017.

380 L. A. Wily, 'African court's landmark ruling gives hope to rural people across the continent', The Conversation (19 June 2017), available at: http://theconversation.com/african-courts-landmarkruling-gives-hope-to-rural-people-across-the-continent-79303 (last visited: 5 September 2018). Murray \& Long (2015), 157. 
Strasbourg, France. In America, as of yet, a dual system, which consists of the Inter-American Commission and the Inter-American Court of Human Rights is still in place. ${ }^{382}$

\section{e) Enforcement of the judgments of the African Court on Human and Peoples' Rights}

The enforcement of judgments issued by international human rights courts regularly depends on the political will of Heads of State and Government and requires a strong standing of the respective court within the respective institutional structure.

The Protocol to the Court provides for remedies in cases of human rights violations. First, the Court may try to reach an amicable settlement between both involved parties. However, in such cases where the violation of fundamental human rights is involved, for instance, war crimes or crimes against life and human dignity an amicable settlement can be difficult to reach. ${ }^{383}$

If no amicable settlement is possible, the Court may choose from an 'open-ended list of appropriate measures.' ${ }^{384}$ The wording of Art. 27(1) of the Protocol comes close to the wording of Art. 63(1) of the American Convention. However, in the European system, Art. 41 of the European Convention gives the Court a much narrower competence regarding remedies since the competences are limited to afford satisfaction to the involved parties.

After the remedy is determined, the AU Executive Council is eligible to ensure the effective implementation of the judgment. ${ }^{385}$ In order to fulfill the obligations, the Council should, on a regular basis, inscribe the missing implementation on the agenda of the respective State. If the State in question does not comply with the judgment, the AU Assembly may determine further measures of political and economic nature. ${ }^{386}$ In order to keep the overview with the activities of the Council, the Court should work closely with the Council.

It is a principle of 'international law that the judgments of a transnational organ do not have positive legal effect in the domestic legal order of the State to which it is directed or overturn any domestic law which it seeks to override. ${ }^{387}$ In general, international courts do not seek to be courts of appeal to overrule the decisions of a domestic court. The African Court of Human and Peoples' Rights likewise is not competent to do so.

\footnotetext{
382 Viljoen (2007), 11.

383 Mangu (2004), 160.

384 Viljoen (2007), 453.

385 See: Arts. 29 and 30 of the 1998 Protocol to the African Charter on Human and Peoples' Rights on the Establishment of an African Court on Human and Peoples' Rights.

386 See: Art. 23(2) of the 2000 Constitutive Act of the African Union.

387 Cole (2010), 42.
} 
However, by virtue of Art. 30 of the Protocol, State parties bind themselves to abide by judgments and to ensure their execution. Thus, the involved States carry out their obligations concerning the principle pacta sunt servanda. On the other hand, there are effectively no provisions outlining the consequences in cases of non-compliance.

The only provision is set out in Art. 31 of the Protocol, where the Court can transfer a report to the Assembly and which shall mention those States that do not comply with the orders of the Court. However, it appears unlikely that dictators or similar would care about such public shaming.

Furthermore, in accordance with the Protocol to the Court, the Court is mandated to issue provisional measures in cases of extreme urgency and gravity similar to the African Commission. Due to the use of the wording 'findings' (finding of a violation, a remedy or a provisional measure) in Art. 27(2) -the question arises if a provisional measure can be seen as a judgment which would then be binding and final. ${ }^{388}$

In March 2011, the African Court granted an order including provisional measures regarding the situation in Libya in the case of African Commission on Human and Peoples' Rights v. Great Socialist People's Libyan Arab Jamahiriya ${ }^{389}$ The order was issued after a submission to the Court by the African Commission.

In 2011 protest spread all around in Libya. At this point, the situation was not yet comparable to an internal armed conflict. The Egyptian Initiative submitted the first request jointly for Personal Rights, Inter-rights, and Human Rights Watch. They applied for the issuing of provisional measures to stop the unlawful and inhumane termination of the protests.

After having received complaints by 5 different NGOs concerning the human rights situation in Libya, the Commission forwarded the case to the African Court. In its petition or application, the Commission alleged serious human rights violations. ${ }^{390}$

In the order issued, the Court requested that Libya immediately refrain from any action which results in loss of life or in the violation of physical integrity. Furthermore, Libya was supposed to report any measures for the implementation of the order within 15 days. ${ }^{391}$

The granting of provisional measures can be interpreted as an innovative step since the African Commission did not even ask for such a measure. ${ }^{392}$ The Court decided to implement provisional measures without written or oral hearing, since

\footnotetext{
388 Viljoen (2007), 428.

389 African Commission on Human and Peoples' Rights v. Great Socialist People's Libyan Arab Jamahiriya, Application No. 004/2011, Judgment of 15 March 2013.

390 J. Oder, 'The African Court on Human and Peoples' Rights' order in respect of the situation in Libya: A watershed in the regional protection of human rights?' 2 Afr Hum Rts LJ (2011), 495, 498.

391 Swart (2013), 444.

392 Oder (2011), 496.
} 
'there exist[ed] a situation of extreme gravity and urgency, as well as a risk of irreplaceable harm to persons who are subject to application, in particular, in relation to the rights to life and to physical integrity of persons guaranteed in the Charter.' ${ }^{393}$

However, before issuing any provisional measures, the Court needed to ensure that it had prima facie jurisdiction. The Court affirmed this, basing its decision on three facts: first, it determined that the dispute related to the interpretation of the Charter and other international instruments that may be relevant. Second, it confirmed Libya to be party to the Charter and the Protocol. Third, the Court confirmed that the Commission was able to submit cases to the Court. ${ }^{394}$

The Court decided in conformity with the provisions of Art. 27(2) of the Protocol and Art. 51(1) of the Interim Rules of the Court, which provides that 'in cases of extreme gravity and urgency, and when necessary to avoid irreparable harm to persons, the Court shall adopt such provisional measures at it deems necessary.' Furthermore, Art. 51 of the Court's Rules of Procedure states that the Court may, based on the 'request of the Commission or on its own accord, prescribe to the parties any interim measure which it deems necessary to adopt in the interest of the parties or of Justice. ${ }^{395}$ Since Libya ratified the Protocol to the Court, the provisions of Art. 3 of the Protocol were likewise met. Art. 3 states that 'the jurisdiction of the Court extends to all cases and disputes submitted to it concerning the interpretation and application of the African Charter, this protocol and any other relevant human rights instrument ratified by the States concerned'. 396

The Court finally granted provisional measures nine days after the registry received the application by the Commission. This could be regarded as a positive sign, taking into consideration the delays that are normal regarding the Commission's litigation procedure. ${ }^{397}$

With its findings, the Court signalled its commitment regarding the preservation of life by acting proprio motu, since it gave direct and unequivocal orders to Libya. Furthermore, the joint acting of the Commission and the Court shows the existence of strong institutions promoting the rule of law. ${ }^{398}$

After unsuccessfully extending the time frame for Libya to transact the order of the Court it briefed the key organs of the AU on the non-compliance of Libya.

In order to emphasize the importance of the effective implementation of the rulings, the Court noted in the Interim Report:

393 See: African Commission on Human and Peoples' Rights v. Great Social People's Libyan Arab Jamahiriya, Application No. 004/2011, Judgment of 15 March 2013, para 22.

394 R. J. V. Cole, 'The Emerging Jurisprudence of the African Court on Human and Peoples' Rights - African Commission on Human and Peoples' Rights v. Great Socialist People's Libyan Arab Jamahiriya (Order for Provisional Measures) Note', 14 U Botswana LJ (2012), 150. Oder (2011), 500.

396 Ibid.

397 Ibid.

398 Cole (2012), 153. 
[T] he failure of Libya... to comply with the Order of the Court, threatens the very foundation of the existence of the Court as a judicial arm of the African Union. It erodes public confidence in our judicial system and mobilizes negative public perception about the ability of the Court to protect human rights on the continent. Furthermore, such non-compliance by any Member State tends to put into question the credible utility of the judicial system created by the AU for the enforcement of the African Charter on Human and Peoples' Rights. ${ }^{399}$

In its interim report, the Court also demanded the adoption of a special 'concrete mechanism' in order to implement the order of the Court much more effectively. ${ }^{400}$ The enforcement of the judgments remains an issue of the African Court. Member States to the Protocol on the Court do not - despite the ratification of the Protocol - ensure the enforcement of the judgments.

Most recently, the Court delivered a landmark decision ${ }^{401}$ which could affect the whole continent. The Court held that in depriving someone of his citizenship, Tanzania acted unlawfully. The Court stated that depriving someone of his or her citizenship without a fair judicial process would be in breach of the Universal Declaration of Human Rights. It is the first time that an African Court decided on matters relating to citizenship. Since the African Charter does not include a right to nationality, the Court referred to the Universal Declaration of Human Rights, which includes such provision. The Republic of Tanzania - after the judgment - was provided with 45 days to restore the citizenship of the applicant. ${ }^{402}$ If Tanzania did comply with the judgment remains unknown.

\subsubsection{Conclusion African Court on Human and Peoples' Rights}

The election of the judges of the African Court on Human and Peoples' Rights almost twenty-five years after the adoption of the Charter on Human and Peoples' Rights constituted a milestone in matters of human rights protection in Africa.

Comparing the developments of other human rights courts in the world with the African Court on Human and Peoples' Rights, there is reason for optimism. The Inter-American System and the former European system did not provide for direct access for individuals. They did, similarly to the African system, establish a Commission, with the power to refer human right cases to the Court. These requirements of the former European and the American systems did deem them inefficient. ${ }^{403}$ The African Court of Human and Peoples' Rights, however, is confronted with issues

\footnotetext{
399 See: Annual Report of the African Court for the Year 2013, EX/CL/825(XXIV), paras 28-33.

400 Murray \& Long (2015), 141 et seq.

401 Anudo Ochieng Anudo v. The Republic of Tanzania, Application No. 012 2015, Judgment of 22 March 2018.

402 R. Carmel, 'African Court delivers a Landmark decision on statelessness', African Legal Information Institute (6 May 2018) available at: https://africanlii.org/content/african-courtdelivers-landmark-decision-statelessness, (last visited: 5 September 2018). 
that did not exist either in the European nor the American system, such as the fact that - in proportion - only a relatively small number of States has thus far ratified the Protocol to the Court.

As of yet, most Member States have neither ratified the Protocol nor filed a declaration allowing individuals and NGOs to gain access the Court, meaning that the Court lacks jurisdiction to receive declarations being submitted by individuals and NGOs. ${ }^{404}$

The success of the Court is merely dependent on the exercise of the office of the judges to enforce the protection of human rights in Africa. ${ }^{405}$ For instance, the Court could give a wide interpretation to articles 34(6) and 5(3) establishing the African Court on Human and Peoples' Rights in order to guarantee access to the Court of NGOs and individuals. ${ }^{406}$

Another issue affecting the effectiveness of the Court is the lack of coordination, resulting in overlapping jurisdictions and other phenomena, such as overlapping labor within the Court and other institutions of the African Union. This is illustrated by the non-definition of the relationship between the Court and the Commission. ${ }^{407}$ The Commission is often criticized as ineffective but on the other hand, it is entitled to refer cases submitted by individuals to the Court. Thus, the functioning and the assertion of human rights involving NGOs and individuals by the Court depend on an institution which is not yet working very smoothly.

Furthermore, the Court thus far has issued only very few decisions, concluding in most that it is not competent to hear cases brought by either NGOs or individuals since their home countries have not made a declaration under the provisions of Art. 34 of the Protocol. ${ }^{408}$ Notwithstanding the low volume of case law produced by the Court, it turned out to be a key actor in the protection of human rights. Under the broad wording of Art. 27 of the Protocol, the Court managed to develop its competences.

By virtue of the competence to apply international law in general, the Court may still enlarge its mandate. However, many cases are of political sensitiveness and thus, it is not guaranteed that the Court continues with its activism. ${ }^{409}$

Therefore, a closer cooperation with the Commission would increase the effectiveness of the Court as well as its standing within the African Union. Especially regarding the realization of human rights through the individuals before the Court,

\footnotetext{
404 Ssenyonjo (2013), 30.

405 Ankumah (1996), 16.

406 R. Murray \& E. Malcolm, The State Reporting Mechanism of the African Charter, The African Charter on Human and Peoples Rights - The System in Practice, 1986-2006 (2006), 69.

407 K. O. Kufour, The African Human Rights System - Origin and Evolution (2010), 125.

408 G. Pecorella, 'The African Court on Human and Peoples' rights and its case law: towards a Supreme Court for Africa?' (2015), available at: https://aninternationallawblog.wordpress. com/2015/06/22/the-african-court-on-human-and-peoples-rights-and-its-case-law-towards-asupreme-court-for-africa/ (last visited: 25 July 2018). 
the Commission has a very important role, as only six States allow individuals to bring cases directly before the African Court on Human and Peoples' Rights. In the past the Commission forwarded some cases to the Court, whereof the majority however was rejected due to inadmissibility.

Moreover, the little number of cases may be caused by a lack of awareness of the existence of the Court. In addition, the procedure of the Court remains quite slow and thus it generally takes a long time until the Court issues a judgment. ${ }^{410}$ One reason is the fact that the Court is still an ad hoc institution. The main reason for this fact is the limitation of financial resources of the AU level.

\subsubsection{The Merger between the African Court of Human and Peoples' Rights and the African Court of Justice}

Consequently in 2004, it was decided to merge the African Court on Human and Peoples' Rights and the African Court of Justice in order to reduce the costs of funding of both institutions. ${ }^{411}$

The idea of a merger between the two Courts materialized mainly due to economic issues since the African Union was not able to cover the costs of two courts within its institutional system. ${ }^{412}$

In order to merge both courts - the African Court on Human and Peoples' rights and the African Court of Justice - a draft protocol was presented to the Executive Council on May in 2005 during its summit in Nigeria. In order to react reasonably to the draft, the Executive Council decided to convoke a meeting of legal experts from the Member States. The Council recommended that both courts should continue its efforts of becoming operational.

In 2005, the former president of the ICJ, Justice Mohamed Bedajoui offered to draft a Protocol in order to merge both courts. The AU Assembly accepted the offer in the same year.

After the implementation of several draft Protocols, the draft was finally adopted by the Conference of Heads of State and Government during the Summit in Sharm El Sheikh in July 2008, after being presented to the Justice Ministers and public prosecutors. ${ }^{413}$ To become effective, the Protocol needs to be adopted by a minimum of 15 Member States of the African Union. ${ }^{414}$ Once sufficient numbers of Member States adopt the Protocol, the two previous courts will be merged into one court. ${ }^{415}$ As per the Protocol, the African Court on Human and Peoples' Rights will remain

410 E. Polymenopoulou, 'African Court on Human and Peoples' Rights, African Commission on Human and Peoples' Rights v Great Socialist People's Libyan Arab Jamahiriya, Order for Provisional Measures 25 March 2011', 61 Int'l \& Comp LQ 3 (2012), 768.

411 Ssenyonjo \& Nakitto (2016), 72.

412 Eze (2009), 247.

413 Kane \& Motola (2008), 410.

414 See: Art. 9 of the 2008 Protocol on the Statute of the African Court of Justice and Human Rights.

415 See: Art. 2 of the 2008 Protocol on the Statute of the African Court of Justice and Human Rights. 
active for a transition period not exceeding one year in order to transfer its prerogatives, properties, rights and its obligations to the merged court. ${ }^{416}$ Any cases, that are pending on the African Court on Human and Peoples' Rights will be transferred to the single court. ${ }^{417}$ Additionally, the judges serving for the African Court on Human and Peoples' Rights will remain in office until the judges of the merged Court are sworn in. ${ }^{418}$

After the end of the transition period, the Protocol of the African Court on Human and Peoples' Rights will become repealed. ${ }^{419}$ Lastly, it is necessary that at least 16 States ratify the Protocol on the merged Court since the latter provides that 16 judges, who all need be citizens of a State being party to the Protocol, are required. Thus, the Court may effectively only come into existence after 16 States sign the Protocol of the Statute of the African Court of Justice and Human Rights.

Until 2015, five African States, including Kenya, signed the protocol on the creation of the African Court of Justice and Human Rights, which includes the jurisdiction of the Court on criminal cases. ${ }^{420}$ Most recently Kenya stated that the government would ensure effective lobbying to convince more African States to sign the Protocol.

\section{a) The structure of the African Court of Justice and Human Rights}

Pursuant to Art. 1 of the Protocol on the Statute of the African Court of Justice and Human Rights, the Protocols of the African Court of Justice and the African Court of Human and Peoples' Rights will be replaced by the new Statute and Protocol. Since the Protocol and Statute of the African Court of Justice and Human and Peoples' Rights are not yet ratified by a sufficient number of States, the above-named Protocols remain in power.

In accordance with Art. 2 of the Protocol, the African Court on Justice and Human Rights will become the main judicial body of the Union. The seat of the merged Court will be the same as that of the African Union on Human and Peoples Rights, which is Arusha in Tanzania, as per Art. 25.

Furthermore, Art. 19 states that the new Court is supposed to be divided into two sections: the Human Rights Section and the Section on General Affairs. Claimants alleging the violation of human rights must indicate the possible violation of human rights, pursuant to Art. 34(1) of the Protocol of the merged Court. ${ }^{421}$

\footnotetext{
416 See: Art. 7 of the 2008 Protocol on the Statute of the African Court of Justice and Human Rights.

417 See: Art. 5 of the 2008 Protocol on the Statute of the African Court of Justice and Human Rights.

418 See: Art. 4 of the 2008 Protocol on the Statute of the African Court of Justice and Human Rights.

419 International Federation for Human Rights, Practical Guide - The African Court on Human and Peoples' Rights - towards the African Court of Justice and Human Rights, (April 2010), available at: https://www.fidh.org/IMG/pdf/african_court_guide.pdf., (last visited: 5 September 2018), 144.

420 Ssenyonjo \& Nakitto (2016), 73.

421 Naldi \& Magliveras (2012), 396.
} 
The Court will consist of sixteen Judges who are nationals of the Member States in accordance with Art. 3(1) of the Protocol. Art. 3(3) of the Protocol stipulates that each geographical region of the continent shall be represented by three judges except the region of Western Africa which shall be represented by four judges. The judges shall be independent and persons of high moral character who own the appropriate qualifications, as derived from Art. 4 of the Protocol.

After the effective establishment of the Court, each State party shall present two candidates. Then, the Chairperson of the Commission is entitled to present a list to the Member States, Art. 6(4) of the Protocol. The candidates will be elected through the Executive Council and will be finally appointed by the Assembly, as per Art. 7(1).

Pursuant to the provisions of Art. 20 of the Protocol, the Court is entitled to hold ordinary as well as extraordinary sessions. The number and length of such sessions will be decided by the Court annually. However, the exact regulations of the sessions have not yet been formed. ${ }^{422}$

Each section within the merged Court will have the opportunity to establish several integrated chambers. ${ }^{423}$ However, the Protocol does not provide for the establishment of an appellate jurisdiction. ${ }^{424}$

\section{b) Competences of the African Court of Justice and Human Rights}

The competences of the merged Court are significant regarding the future protection of human rights throughout the African continent.

The Section on General affairs will be able to hear all cases brought before it in accordance with Art. 28 of the Protocol. ${ }^{425}$ The said Section will have more or less the same jurisdiction as the Court of Justice. Consequently, it will be competent amongst other things - on matters concerning the interpretation and application of the Constitutive Act of the AU, the interpretation, application or validity of other Union treaties and all legal instruments derived and adopted within the framework of the OAU and the African Union, all acts, decisions, rulings or directives by Union bodies. The section on Human and Peoples' Rights will, to a certain extent, continue the mandate of the prior African Court on Human and Peoples' Rights.

Pursuant to Art. 17(2) of the Protocol, the human rights section 'shall be competent to hear all cases relating to human and/or peoples' rights.' Furthermore, Art. 28(c) of the Protocol states that the Court shall have jurisdiction on all cases relating to 'the interpretation and the application of the African Charter, the Char-

\footnotetext{
422 Ibid.

423 See: Art. 19(1) of the 2008 Protocol on the Statute of the African Court of Justice and Human Rights.

424 International Federation for Human Rights, Practical Guide - The African Court on Human and Peoples' Rights - towards the African Court of Justice and Human Rights, (April 2010), available at: https://www.fidh.org/IMG/pdf/african_court_guide.pdf., (last visited: 5 September 2018), 148. Ibid., 149.
} 
ter on the Rights and Welfare of the Child, the Protocol to the African Charter on Human and Peoples' Rights of Women in Africa, or any other legal instrument relating to human rights, ratified by the States parties concerned.'

Similar to the African Court of Human and Peoples' Rights, the new Court is mandated to give a legal opinion with regard to any legal matter that is not brought before either the African Commission or the African Committee of Experts. ${ }^{426}$

Arts. 29 and 30 of the Protocol of the merged Court govern the question of the locus standi.

Art. 29 provides for a general locus standi with regard to all cases except for human rights matters, whereas Art. 30 refers to requirements of access regarding the violation of human and peoples' rights. Art. 29(1) provides access to the Court for (a) contracting parties to the 2008 Protocol; b) the Assembly, the Pan-African Parliament (PAP) and other AU organs, and c) AU employees, who in accordance with Regulation 14 of the AU Staff Regulations and Rules have appealed against a decision rendered in the context of labor dispute with the Organization. The PAP may have been considered a preferred applicant since it has the status of the representative of the African people. ${ }^{427}$

Regarding the accessibility of individuals, Art. 30(f) states that '[i]ndividuals or relevant non-Governmental Organisations accredited to the African Union or its organs, subject to the provisions of Art. 8 of the Protocol' are eligible to submit cases to the Human Rights Section of the merged Court. This requirement may lead to issues for many NGO's. Those NGOs cannot rely on their observer status at the African Commission for access to the Court, as the African Commission is not an official organ of the African Union. The requirements for accreditation of NGOs by the AU require inter alia that two-thirds of the NGOs funding come from its members. ${ }^{428}$

According to Art. 8(3) of the Protocol of the Statute of the African Court of Justice and Human Rights '[a]ny Member State may, at the time of signature or when depositing its instrument of ratification or accession, or any time thereafter, make a declaration accepting the competence of the Court to receive cases under Art. 30(f) involving a State which has not made such a declaration.' The requirement thus is similar to the locus standi requirement of the still active African Court on Human and Peoples' Rights.

Given the fact that most States are not expected to make such a declaration, most individuals will not have access to the new Court. Thus, they are - as with the African Court on Human and Peoples' Rights - relying on the activism of the Commission and African intergovernmental organizations.

The de facto inaccessibility of the Court for individuals remains one of the major weak points within the human rights system of the African Union. ${ }^{429}$

\footnotetext{
426 Muigai (2012), 280.

427 Naldi \& Magliveras (2012), 399.

428 Kane \& Motola (2008), 431.

429 Muigai (2012), 281 et seq.
} 


\section{c) Concerns on the planned merger of the African Court of Justice and the African Court of Human and Peoples' Rights}

The planned merger of both Courts leads to both: much criticism but also support throughout the continent. While promoting the process of a successful merger of both Courts, the current Kenyan President Uhuru Kenyatta announced that his country would contribute US\$ 1 million for the African Court of Justice and Human and Peoples' Rights to become operational. ${ }^{430}$

However, the proposed merger of the two Courts ensues many serious concerns. One of the criticisms is that the significance of the human rights is going to be undermined. In general, jurisdiction on human rights needs specialized staff and a convenient institution. With the merged Court, there is no guarantee that a sufficient emphasis and attention will be given to the human rights cases. ${ }^{431} \mathrm{~A}$ further issue regarding the African Court of Justice and Human Rights is the variety of legal systems within the African States. In addition to that, the funding of AU institutions is normally dependent on financial aid of Western States. Despite the Kenyan donation, the Court will sooner or later be dependent on Western countries, which may influence the rulings of the Court. Lastly, like in most regional courts, the judges are still announced by the governments of the Member States pertaining the judges' influence on a high level. ${ }^{432}$

In order to eventually perform the merging of both of the Courts, an interpretive hurdle needs to be crossed: The AU Resolution uses the phrase integration into one court'. The phrasing could either mean the folding of financial and physical resources of the Courts - the Court would as consequence share the building, libraries, and the technical equipment.

The other interpretation of the phrasing would lead to the full fusion of both Courts ending in the creation of a single Court. In contrast to the first interpretation, the full fusion would require an amendment of the already existing Protocols. Anyways, the second concept would lead to greater savings on personnel and other resources. ${ }^{433}$

Furthermore, as discussed, the focus on as well as the prominence of human rights may be reduced within a merged Court. This concern may already find its confirmation in the reduction of the judges with competences and expertise on human rights. The current African Court of Human and Peoples' Rights provides for eleven judges. The Protocol of the merged Court provides for eight judges, with only five of them being required to possess an expertise in human rights matters. ${ }^{434}$

$430 \quad$ Naldi \& Magliveras (2012), 397.

431 Ndulo (2008), 197.

432 Ibid., 199.

433 Kindiki (2007), 140.

434 F. Viljoen, 'AU Assembly should consider human rights before adopting the Amending Merged African Court Protocol' (23 May 2012), AfricLaw, available at: https://africlaw.com/2012/05/23/ au-assembly-should-consider-human-rights-implications-before-adopting-the-amending-mergedafrican-court-protocol/ - more-213, (last visited: 5 September 2018). 
Despite the concerns, the merger will lead to great savings of the African Union each year. Furthermore, the merger of both Courts avoids the development of a duplicate human rights jurisdiction. It is likely that the jurisdiction - also relating to General Affairs matters will be 'infused' with human rights jurisdiction. With the Protocol on the merged Court stating that the Assembly in case of non-enforcement of the Courts' jurisdiction may impose economic or political sanctions to the involved State, the Court provides for quite effective enforcement regulations. ${ }^{435}$

\subsubsection{Conclusion regarding the merge of the African Court of Justice and the African Court on Human and Peoples' Rights}

The decision on the merger of the two Courts was a sudden one and thus led to many uncertainties with regard to the set-up of an effective legal institution.

After the decision of the merger, many NGOs, especially the Coalition for the Establishment of an Effective African Court had great concerns about the effects on the establishment of the African Court. The main concern of the NGOs was the possible suspension of the Protocol on the African Court of Human and Peoples' Rights and consequently the prevention of the establishment of the Court. However, since fifteen AU Member States already adopted the Protocol it already became effective without the Assembly having the competence to stop this process. ${ }^{436}$

Additionally, the argument of funding does not seem to be convincing, as most of the AU institutions, such as the Pan-African Parliament, the Peace and Security Council and the African Commission, have been notoriously underfunded. Therefore, it is unlikely that the merged Court will be equipped adequately with funds. ${ }^{437}$

Another issue still not considered - but discussed in Chapter 8 - is the question of the relation of the merged Court but also the African Court of Human and Peoples' Rights to the regional courts, such as ECOWAS or EAC. The new Protocol does not provide for any regulation on this matter. Above all, where several courts have the same jurisdiction, the issue of forum shopping may arise. Another issue would be if the claimant were unsuccessful before a regional court. Is the merged Court competent in receiving such a case? If so, it would constitute a court of appeal. ${ }^{438}$

Since the Assembly of the Heads and Government and States, as well as the Executive Council, need to approve all decisions made by the Court, the effectiveness of the latter is enormously dependent on the political support of the different governments. ${ }^{439}$ Additionally, the relation to the Commission would need to be defined: Due to the

\footnotetext{
435 Muigai (2012), 281.

436 D. S. Zimbler, 'Africa: Towards an Effective Human Rights Architecture?', in J. Akokpari \&

D. S. Zimbler (eds), Africa’s Human Rights Architecture (2008), 280.

437 Kane \& Motola (2008), 416 et seq.

438 Ibid., 439.

439 Ibid., 437 et seq.
} 
very low level of human rights within the whole continent, the new Court may be flooded with cases. In order to prevent this, the Commission may collaborate with the Court while functioning as a filter regarding questions concerning the competence of the Court. ${ }^{440}$

\subsubsection{The Establishment of the International Criminal Chamber within the African Union}

Following the end of World War II, governments worldwide decided to introduce an international criminal law system. Thus, the 1998 UN Diplomatic Conference of Plenipotentiaries on the Establishment of an International Criminal Court inaugurated the ICC. ${ }^{441}$ The ICC remains the only international institution with the mandate to prosecute individuals for international crimes. ${ }^{442}$ The ICC is not an organ of the United Nations and it derives its powers from the Rome Statute of the International Criminal Court. The Statute only binds States if they ratify the treaty. Even though the ICC does not form part of the UN, the links between both institutions are well-developed. ${ }^{443}$

Traditionally, criminal law was part of the domestic legal system of every State considering the principle 'Nullum crimen, nulla poena sine praevia lege. ${ }^{444}$ In the context of international criminal law, the principle of State sovereignty remains very important - generally, States do not want to give up their competencies with regard to criminal law. ${ }^{445}$

The aim of international criminal law, in general, is to ensure that crimes against humanity, thus crimes of a very grave nature do not remain unpunished. The first time in history where this principle was implemented was the 1945-1946 Nuremberg Trials. In general, international criminal courts only have limited powers since they are founded upon treaties, which are depended on the will of involved Heads of States and Government. ${ }^{446}$

According to Art. 5 of the Rome Statute, the ICC has jurisdiction on crimes such as the crime of genocide, crimes against humanity, war crimes and the crime of aggression being committed by a national of a State Party, or within the territory of a State party or in the event that a State party declared its acceptance of the jurisdiction of the Court under Art. 12(3) of the Rome Statute.

\footnotetext{
440 Ibid.

441 For more details see: M. Ellis, C. Jalloh, The International Criminal Court in an effective global justice system, (2016).

442 M. Swart, 'Towards a Multi-Layered System of International Criminal Justice', in A. E. Ankumah, (ed), The International Criminal Court - One Decade On (2016), 142.

443 Viljoen (2007), 75.

444 O. Quirico, 'General Principles of International Criminal Law and their Relevance to Africa', 17 African Yearbook of International Law (2009), 140.

445 E. W. Ngolo, 'Analysing the Future of International Criminal Justice in Africa: A Focus on the ICC', 1 Strathmore L Rev (2016), 103.

446 Ibid.
} 
Due to many conflicts between African countries and the ICC, the African Union intends to extend the jurisdiction of the merged African Court to also cover war crimes. ${ }^{447}$ This plan makes the establishment of the merged African Court of Justice and Human Rights even more complicated and could lead to immense limitations regarding the protection and promotion of the rule of law. ${ }^{448}$

The Criminal Chamber of the African Court of Justice and Human Rights will form a new 'institutional creature' which remains entirely unprecedented in the criminal system worldwide. ${ }^{449}$

In general, the relationship between African States and the ICC appears tense, since the ICC is 'widely perceived as selective and biased against Africa. ${ }^{450}$ Furthermore, the African Union accuses the ICC of being a 'neo-imperialistic toll that illegitimately targets Africa. ${ }^{451}$ This accusation can find its merit in the fact that the ICC until today mostly examines cases where Africans are prosecuted. ${ }^{452}$

The Protocol on Amendments to the Protocol on the Statute of the African Court of Justice and Human Rights, including the creation of a Criminal Chamber, was in fact, adopted in June 2014 during an AU Assembly. 453

Recently, during the Summit of Heads of State and Government in Addis Ababa at the beginning of 2017, AU leaders proposed to perform a collective withdrawal from the Rome Statute ${ }^{454}$. 455

$\overline{447}$ Maungandize \& du Plessis (2015), 79.

448 Ssenyonjo (2013), 19.

449 O. Mbori, 'The Merged African Court of Justice and Human Rights (ACJ\&HR) as a Better Criminal Justice System than the ICC: Are We Finding African Solution to African Problems or Creating African Problems without Solutions?' (3 June 2014), available at SSRN: https://ssrn. com/abstract=2445344 (last visited: 6 September 2018).

450 K. Kindiki, 'The proposed integration of the African Court of Justice and the African Court of Human and Peoples' Rights: legal difficulties and merits', 15 African Journal of International and Comparative Law 1 (2007), 138, 140.

451 O. Imoedemhe, 'Unpacking the tension between the African Union and the International Criminal Court: the way forward', 23 Afr Hum Rts LJ 1 (2015), 74.

452 O. Mangandize \& A. du Plessis, 'The ICC and the AU' in C. Stahn (ed), The Law and Practice of the International Criminal Court (2015), 65, 79

453 C. S. Igwe, 'The ICC's Favourite Customer: Africa and International Criminal Law', 41 Comp \& Int'l LJ S Afr (2008), 295 et seq.

454 The Rome Statute of the International Criminal Court is the treaty establishing the International Criminal Court. It was adopted during a diplomatic conference in Rome on 17 July 1998 and entered into force on 1 July 2002. As of March 2016, 124 States ratified the statute. Among other things, the statute regulates the functions, jurisdiction and structure of the Court. The Rome Statute established four core international crimes: genocide, crimes against humanity, war crimes and the crime of aggression. Those crimes 'shall not be subject to any statute of limitations'; See: Art. 29 of the Rome Statute.

455 R. Bellelli, International Criminal Justice - Law and Practice form the Rome Statute to Its Review (2010), 58. 


\section{a) Political Background: the indictment of al-Bashir}

One of the main reasons for the tensions between the African Union and the International Criminal Court is the indictment of the Sudanese President Omar alBashir, ${ }^{456}$ on grounds of numerous human right violations in the Darfur region of Sudan since 2001.

In that period, the Janjaweed militia ${ }^{457}$ carried out many attacks as well as perpetrated atrocities on the civilian population that led to 'wholesale forced displacement.' ${ }^{458}$

Consequently, the UN Security Council decided that the conflict constitutes a violation of international peace and security and therefore imposed several sanctions and contemporaneous asked the government of Sudan to disarm the militia in order to stop the attacks. ${ }^{459}$

Additionally, the International Commission of Inquiry on Darfur was set up to investigate the possible violations of human rights. The Commission held that the government of Sudan as well as the Janaweed were responsible for numerous violations of human rights resulting in the violation of international law and recommended the intervention of the ICC. As consequence of this determination, the Security Council ${ }^{460}$ decided to 'refer the situation in Darfur since 1 July 2001' to the ICC Council for prosecution on grounds of Art. 13(b) of the Rome Statute through the adoption of the resolution 1593 in 2005.

456 Omar Hassan Ahmed al-Bashir came to power in 1989 when, as a brigadier in the Sudanese Army, he led group of officers in a military coup that ousted the democratically elected government of prime minister Sadiq al-Mahd after it began negotiations with rebels in the south. Since then, he has been elected three times as President that has been under scrutiny for corruption, see: J. Mackenzie, 'FACTBOX - Sudan's President Omar Hassan al-Bashir', Reuters (14 July 2008), available at: https://www.reuters.com/article/uk-warcrimes-sudan-bashir-profile/factboxsudans-president-omar-hassan-al-bashir-idUKL1435274220080714, (last visited: 11 September 2018).

457 The Janjaweed are a militia operating in Western Sudan and eastern Chad. Regarding the definition of the United Nations, the Janjaweed comprised Sudanese Arab tribes, the core of whom are from the Abbala (camel herder) background with significant recruitment from the Baggara (cattle herder) people. However, in additionally other members of other tribes have been noted. The Janjaweed appeared in 1988 for the first time, after the Chadian President Hissène Habré, being backed by the United States and France defeated the Libyan army; see Human Rights Watch, Failing Darfur - Entrenching Impunity: Government Responsibility for International Crimes in Darfur, available at: https://www.hrw.org/legacy/features/darfur/fiveyearson/report4.html, (last visited: 9 September 2018).

458 Viljoen (2012).

459 K. Magliveras \& G. Naldi, 'The ICC Addresses Non-Cooperation by States Parties: The Malawi Decision' 6 Afr J Legal Stud (2013), 137, 139.

460 The Security Council is one of the six principal organs of the United Nations, charged with the maintenance of international peace and security as well as accepting new members to the United nations and approving any changes to the Charter of the United Nations. The Security Council is the only body which may establish binding resolution to Member States. It is also is mandated to establish peacekeeping operations, the establishment of international sanctions and the authoriza- 
Later on, the Security Council announced its will to seek an arrest warrant against al-Bashir on the basis of genocide and crimes against humanity ${ }^{461}$

Hereupon, the Pre-Trial of the ICC issued an arrest warrant against Al-Bashir and concluded, that him being a 'Head of State of a non-state party' was no obstacle to the jurisdiction of the ICC in 2009. In 2010, the ICC prepared a second arrest warrant pertaining to al-Bashir and accused him of being an indirect co-preparator of acts of international crimes. ${ }^{462}$

In the al-Bashir case the issue of immunity remains controversial. Art. 27 of the Rome Statute clearly states that 'the statue shall apply without any distinction and that official capacity, in particular, that of a Head of State, will not exempt any person from criminal responsibility, nor shall it constitute ground for the reduction of a sentences'. ${ }^{4} 63$ On the side of the $\mathrm{AU}$, it is argued that the provision does not apply since Sudan is not a party to the Rome Statute. Another view points out that Art. 27 applies since the Security Council resolution obligates Sudan expressly to cooperate with the ICC. ${ }^{464}$ Moreover, Art. 98 provides that State parties owe each other to afford immunity to Heads of States in their territory.

\section{b) Issues regarding intervention in Sudan by the International Criminal Court (ICC)}

The intervention of the International Criminal Court in Sudan, especially in the context of the indictment of al-Bashir led to serious legal problems: Sudan is not a party to the Rome Statute and therefore - because of its sovereignty - ignored the arrest warrant. ${ }^{465}$ In order to circumvent the jurisdiction of the ICC, the Sudanese government set up the Special Criminal Court (SCC) appealing on the independence of the Sudanese judiciary. The Sudanese government argued it was capable to execute investigations on war crimes under similar conditions as the ICC. ${ }^{466}$

Furthermore, it was argued that al-Bashir as acting President of the Republic of Sudan enjoys immunity. Art. 27(2) of the Rome Statute states, that '[i]mmunities of special procedural rules which may attach to the official capacity of a person,

tion of military action through resolutions; See: Official Website of the United Nations Security

Council, available at: https://www.un.org/securitycouncil/, (last visited: 2. October 2020).

461 E. Keppler, 'Managing setback for the International Criminal Court in Africa', 56 J Afr L 1 (2012), 1.

462 See: Prosecutor v. Omar Hassan Ahmad al Bashir, Second Warrant of Arrest for Omad Hassan Ahmed Al Bahsir, ICC - 02/05-01/09-)5, P-T, Ch. I, 12 July 2010.

463 Ngolo (2016), 115.

464 Ibid.

465 Keppler (2012), 3 et seq.

466 R. J. V. Cole, 'Africa’s Relationship with the International Criminal Court: More Political than Legal', 14 Melbourne Journal of Int'L (2013), 670, 686 et seq. 
whether under national or international law, shall not bar the Court from exercising jurisdiction over such a person [...]' does not apply to al-Bashir since the Sudan is not party to the Rome Statute. 467

As consequence of the failure of the ICC to obey the will ${ }^{468}$ of the AU Assembly, the latter 'decide[d] that in view of the fact that the requested by the African Union has never been acted upon, the AU Member States shall not cooperate pursuant to the provisions of Art. 98 of the Rome Statute of the ICC relating to immunities, for the arrest and surrender of President Bashir. ${ }^{3} 69$ The AU Assembly took the same position with regard to the warrant arrest of Muammar Gaddafi. African States, such as South Africa and Kenya followed the call of the AU Assembly and did not arrest al-Bashir.

\section{c) Reactions on the indictment of al-Bashir within the African continent}

As a reaction to the procedure of the ICC and the UN in Sudan, the AU requested the UN Secretary Council to defer the case against him - the call was, however, ignored. ${ }^{470}$

Apart from the arrest warrant against al-Bashir, many other proceedings against African State Officials were implemented in the last decade. Among others, the Libyan President Muammar Gadhafi got indicted in France on the accusation of having committed torture and terrorist acts. In the end, the ICC decided in favor of the accused Gadhafi. Moreover, France indicted the former President of Mauritania, Maaouya Ould Sid'Ahmed Taya ${ }^{471}$ and also several State Officers of Rwanda. Since the President Paul Kagame enjoyed immunity, Rose Kabuye, a Rwandan State Official, was arrested while visiting Germany and was handed over to France in 2008 on the basis of her alleged role in the Rwandan genocide. She was released in 2009 after being found not guilty of the crimes of which she was accused. ${ }^{472}$

With regard to Zimbabwe's President Robert Mugabe, the Bow Street Magistrate's Court decided not to arrest him because of the principle of immunity of serving Heads of State. ${ }^{473}$

467 M. Matasi \& J. Bröhmer, 'The proposed International Criminal Chamber section of the African Court of Justice and Human Rights: A legal analysis', 37 South African Yearbook of Int'L (2012), 248, 251.

468 The AU requested the United Nations Security Council to defer the investigation against al-Bashir in respect of the Darfur situation. The United Nations however, did not accept the request. It further stated in its Sirte Declaration that the arrest warrant against the President would 'seriously undermine the on-going efforts' aimed at facilitating peace in Darfur; (see: Cole (2013)).

469 Decision on the Application by the International Criminal Court (ICC) Prosecutor for the Indictment of the President of the Republic of Sudan, Decision Assembly/AU/Dec.221 (XII), Adopted by the Assembly of the AU in Sirte, Libya on 3 July 2009, $\$ 10$.

470 Magliveras \& Naldi (2013), 140.

471 Maaouya Ould Sid'Ahmed Taya was President of Mauritania from 1984 until 2005. In 2005, he was ousted by a military coup, see: Encyclopedia Britannica, Mauritania; available at: https:// www.britannica.com/place/Mauritania/History\#ref1047252 (last visited: 5 September 2015).

472 Keppler (2016), 4.

473 C. B. Murungu, 'Towards a Criminal Chamber in the African Court of Justice and Human Rights', 9 J Int'l Crim Just 5 (2011), 1067, 1069. 
In addition to the arrest-warrant of al-Bashir, the indictment of Uhuru Muigai Kenyatta ${ }^{474}$ in 2011 led to further political resentment towards the ICC on the continent. During the AU Summit in 2013, a decision was adopted which requested the International Criminal Court to remit to Kenya the cases pending against Uhuru Kenyatta. ${ }^{475}$ During the Extraordinary Summit of the African Union in 2013, Kenyatta stated regarding the ICC:

The ICC has been reduced into a painfully farcical pantomime, a travesty that adds insult to the injury of victims. It stopped being the home of justice the day it became the toy of declining imperial powers... It is the fact that this court performs on the cue of European and American governments against the sovereignty of African States and peoples that should outrage us. People have termed this situation 'race hunting', I find great difficulty adjudging them wrong. ${ }^{476}$

Besides the political issues caused by the indictment of President al-Bashir, there are many more detractors of the ICC within the African continent. One of them is President Paul Kagame, ${ }^{477}$ President of Rwanda pertaining the ICC to be a 'fraudulent institution created for poor African States as a form of colonialism and imperialism aimed at control'. ${ }^{478}$ However, his government supported the establishment of the International Criminal Court for Rwanda (ICTR), ${ }^{479}$ but withdrew its support when ICTR took unfavorable positions, such as when it prevented witnesses from leaving Rwanda. ${ }^{480}$

474 Uhuru Kenyarra is the 4th and current President of Kenya and is in office since 2013. He was indicted after being summoned by the ICC Pre-trial chamber and was accused to have committed crimes against humanity; See: J. Patinkin, 'Uhuru Kenyatta's election victory is upheld by Kenya's supreme court', The Guardian (30 March 2013), available at: https:/www.theguardian.com/ world/2013/mar/31/kenya-court-upholds-kenyatta-victory, (last visited: 11 September 2018). Maungandize \& du Plessis (2015), 65.

476 C. M. Peter, 'Fighting Impunity', in E. A. Ankumah(ed), The International Crime Court and Africa - One Decade On (2016), 27.

477 Paul Kagame is the sixth and current President of Rwanda. He is in office since 2000 after his predecessor, Pasteur Bizimungu, resigned. Prior to this, he commanded the rebel force and thus ended the 1994 Rwandan Genocide; See: Official Website of Paul Kagame, available at: http:// paulkagame.com/, (last visited: 11 September 2018).

478 S. Dersso, 'The International Criminal Court's Africa problem,' Aljazeera (11 June 2013), available at: http://www.aljazeera.com/indepth/opinion/2013/06/201369851918549.html (last visited: 25 March 2017).

479 The International Criminal Tribunal for Rwanda (ICTR) was an International Court established in November 1994 by the United Nations Security Council in Resolution 955 in order to judge people responsible for the Rwandan Genocide and other serious violations of international law in Rwanda, or by Rwandan citizens in nearby States, between 1 January and 1 December 1994. The Security Council of the UN called on the tribunal to finish its investigations by the end of 2004 and to complete all trial activities by 2008 and complete all work by 2012 through several resolutions; (see: Official Website of the United Nations, International Residual Mechanism for Criminal Tribunals, available at: http://unictr.irmct.org/, (last visited: 11 September 2018)). 
Other critics argue that the goal of the implementation of international law is to exercise control over poor countries and that the ICC would transfer its mission successfully. Moreover, Mandani describes the ICC as a part of a modern Western colonial process. He further states that international law was used by the West in the past to assert its domination over Africa and, thus, the ICC may well be a replication of the process. ${ }^{\prime 281}$

In summary, most African States reacted negatively on the issuing of the arrest warrants against al-Bashir or the request of later-discussed summons against Kenyatta. Due to the actions commenced against al-Bashir, the relationship between the ICC and the African Continent turned into a rebellion. ${ }^{482}$ The AU Assembly believes that Western States would 'manipulate the ICC in an inadmissible manner in order to target the African continent on an unfair basis.' Furthermore, it believes that

the process initiated by the ICC and the decision of its Pre-Trial Chamber have the potential to seriously undermine the on-going efforts to address the many pressing peace and security challenges facing Sudan and may lead to further suffering for the peoples of Sudan and greater destabilization of the country and the region. ${ }^{483}$

Nevertheless, until 2010 most African countries expressively supported the work of the ICC. Thus, Tunisia ratified the Rome Statute in 2011. ${ }^{484}$ In May 2010, many African governments stated that they would still continue to support the work of the ICC. When al-Bashir visited Kenya in 2011 however, he was not arrested, even though Kenya was obligated to do so under the provisions of the Rome Statute.

\section{d) Political background: The Kenyatta case}

Following the indictment of al-Bashir, the case involving Kenyatta led to further disagreement between the African Union and the ICC.

The Kenyatta case was concluded in 2012 and faced the ICC with a number of struggles and challenges with regard to its legitimacy. The case has gained a new meaning when Uhuru Kenyatta became President of Kenya in 2013. Same happened to Kenyatta's running mate, William Samoei Ruto, who is currently serving as Deputy President of Kenya.

Following the elections of 2007 in Kenya violence within the country erupted. 70 percent of the population in Kenya participated in the elections. Prior to the elections, it was announced that Odinga, from the Orange Democratic Movement, would become the winner of the Presidential elections. However, the Electoral

481 Ibid.

482 C. S. Igwe, 'The ICC's Favourite Customer: Africa and International Criminal Law', 41 Comp \& Int'l LJ S Afr (2008), 321.

483 Magliveras \& Naldi (2013), 141.

484 Murungu (2011), 1078. 
Commission of Kenya declared Kibaki, from the Party of National Unity to be the winner. Following this announcement grave violence took place causing 1000 death and 500,000 displaced civilians in the Rift Valley. ${ }^{485}$ The Commission of Inquiry investigated the violence and published a report in 2008, the so-called Waki Report.

Curiously, the Commission did not name any of the perpetrators in its report but filed a separate list with the names. It was announced that the list should be handed to the ICC Chief Prosecutor Luis Moreno-Ocampo with the instructions to only address the matter if Kenya would not set up a tribunal within one year. When Kenya refused twice to set-up such Court, under the provisions of Art. 15 of the Rome Statute, Moreno-Ocampo used his propio motu power requesting permission to open an investigation in the Republic of Kenya. Kenya, on the other hand, declared that cases have been opened after the post-election violence but not one of the cases was deemed prosecutable.

This was the first time that the Prosecutor made use of the power under Art. 15 of the Rome Statute. In this case, the majority of the Pre-Trial Chamber was of the opinion that there was enough proof that human rights violations took place in Kenya and thus the Prosecutor was granted what he asked for. ${ }^{486}$ In the same year, the Prosecutor Ocampo sought two different summons under Art. 58(7) of the Rome Statute for six individuals: Uhuru Kenyatta, Henry Kosgey, William Ruto, Francis Muthuara, Joshua Arap Sang and Mohammed Hussein Ali.

The request for summons by the Prosecutor was not well-received in Kenya and thus the Parliament of Kenya passed a resolution in December 2010 stating that the country should withdraw from the Rome Statute. ${ }^{487}$

Finally, after a long period of several deferrals of the proceedings before the Trial Chamber due to inter alia missing evidence, the proceedings against Kenyatta were terminated and the summons were quashed. The Trial in December 2014 argued that the 'Kenya's non-compliance [...] compromised the Prosecution's ability to fulfil its mandate. ${ }^{488}$ In this context, the Trial Chamber, due to the country's repeated non-compliance decided to withdraw the legal proceedings against Kenyatta. ${ }^{489}$

The recent ICC cases against African leaders caused the most developed sub-Saharan country to no longer support the ICC.

Recently, the Republic of South Africa tried to withdraw from the ICC due to its failure to arrest al-Bashir, who was in South Africa to attend the African Union Summit in 2015. Since the pre-trial chambers implemented two arrest warrants, South Africa being a signatory State of the Rome Statute was obliged to arrest the

485 C. du Plessis \& M. Gevers, 'Another Stormy Year for the International Criminal Court and its Work in Africa Notes and Comments', 35 S Afr YB Int'l L (2010), 166.

486 Ibid.

487 L. N. Sadatm \& B. Cohen, 'Impunity through Immunity' in E. A. Ankumah, (ed), The International Criminal Court and Africa - One Decade On (2016), 102 et seq.

488 Ibid.

489 J. Emmanuel, 'The International Criminal Court and Sovereignty: What Does Kenyatta Mean for the Future of the ICC', 24 Transat'l. \& Contemp Probs (2014), 133, 139. 
Sudanese President. South Africa, at this point of time, opined that the principle of immunity regarding an active president is a customary international law obligation. ${ }^{490}$ When al-Bashir entered the Republic of South Africa, the Southern African Litigation Centre (SALC) brought an urgent application before the Pretoria High Court. The Court decided that al-Bashir has to be kept in South Africa and that he needs to be arrested. ${ }^{491}$ In the end al Bashir did not attend the inauguration and thus the court application by SALC was unnecessary. ${ }^{492}$

Had South Africa arrested al-Bashir, the country would have been the first African country to cooperate with the ICC. Under the Zimbabwe Torture Docket Case, ${ }^{493}$ South African authorities received many powers to prosecute international war crimes. It appears that those powers - in certain cases - may remain theoretical. ${ }^{494}$

In context with the above-mentioned appeal of the African Union to leave the ICC en masse, the South African government decided to quit the ICC on 19 November 2016 while depositing a withdrawal notice to the UN Secretary General.

Under the provisions set out in the Vienna Convention on the Law of Treaties (VCLT), the most important international instrument dealing with the issue, a State party may withdraw from a Treaty in conformity with the provisions of the involved Treaty.

Regarding a possible withdrawal, Art. 127 of the Rome Statute states that a Member State to the ICC needs to forward a deposit in form of a withdrawal notice to the Secretary-General. The notice comes into effect after twelve months from the deposit day.

There is no doubt about the South African eligibility to quit the Treaty. However - similar to the British Miller judgment, ${ }^{495}$ the Supreme Court of South Africa found, that the withdrawal from the Rome Statute needs to be approved by the Parliament. As a consequence, the withdrawal from the treaty is a legislative function; irrespective of the question of whether the involved country has a dualist or monopolist approach regarding the implementation of the national law.

\footnotetext{
490 Swart (2016), 158.

491 See: Southern African Litigation Centre v. The Minister of Justice and Constitutional Development and Others, Case No. 27740/2015, Judgment of 24 June 2015.

492 Maungandize \& du Plessis (2015), 76.

493 National Commissioner of the South African Police Service v. Southern African Human Rights Litigation Centre and another (2014), ZACC 30, Judgment of 30 October 2014.

494 Swart (2016), 155.

495 The Miller case was decided by the Supreme Court of the United Kingdom and pointed out some procedural questions with regards to leaving the European Union. The key issue was the question if the enactment of Art. 50 of the Treaty of the European Union needs any action by the Parliament or if it would be enacted through 'Royal prerogative'. That means that the executive powers traditionally have the power of negotiation and ratification international treaties. Since the membership of the United Kingdom is merely regulated by the European Communities Act, the Court ruled that Parliamentary consent, in order to enact Art. 50 is necessary; See: Miller and another (Respondents) v. Secretary of State for Exiting the European Union, [2017] UKSC 5, Judgment of 24 January 2017.
} 
Apart from South Africa, also The Gambia and Burundi decided to withdraw from the ICC in October 2016. However, most recently, the new President of The Gambia Adama Barrow again expressed the support for the ICC. Therefore, the situation and the support for the ICC in Africa remains uncertain. Many voices supporting the ICC called the decision of the South African High Court the end of the 'African-exodus' of the ICC. Nonetheless, there is no indication that the South African Government may abandon the idea of withdrawal. ${ }^{496}$

The call of the African Union Summit to support the mass withdrawal from the ICC gained much criticism. According to Desmond Mpilo Tutu, the Archbishop Emeritus of Cape Town, a mass withdrawal would lead to the situation that minorities of the African continent would live insecurely. Further, the African continent would be undermining its voice regarding world affairs, since the continents' voice can only be strengthened with the protection of the rule of law. ${ }^{497}$ The withdrawal from the ICC would undermine the principle of the rule of law, since international war crimes - currently- would not be able to be prosecuted and non-existence of an effective jurisdictional institution, which is competent to hear international crimes does violate the principle of the rule of law.

\section{e) The implementation of the Criminal Chamber to the African Court of Justice and Human and Peoples' Rights}

As a reaction to the recent interventions of the ICC in Africa, the AU decided to set-up its own Criminal Chamber eligible to prosecute International Crimes on African level.

In June 2010, the AU Commission asked consultants to draft an amended protocol on the Statute of the African Court of Justice and Human Rights. The idea of a chamber for international crimes initially formulated in 2009 during the $12^{\text {th }}$ Ordinary Session of the Assembly in Addis Ababa, Ethiopia. The Assembly of the AU accordingly requested:

The Commission, in consultation with the African Commission on Human and Peoples' Rights, and the African Court on Human and Peoples' Rights, to examine the implications of the Court empowered to try international crimes such as genocide, crimes against humanity and war crimes, and report thereon to the Assembly in $2010 .^{498}$

\footnotetext{
496 A. Jospeh, 'Why the South African High Court Ruling on ICC Withdrawal IS Significant for International Law', The Wire (28 February 2017), available at: https://thewire.in/112372/whysouth-african-high-court-ruling-on-icc-withdrawal-is-significant-for-international-law/, (last visited: 20 March 2017).

497 Peter (2016), 35.

498 Ssenyonjo \& Nakitto (2016), 74.
} 
In May 2012, the AU Government Legal Experts meeting reviewed the draft protocol. A couple of days later, the Ministers of Justice and/or Attorneys met to adopt the draft protocol. ${ }^{499}$ The Assembly of Heads of State and Government finally adopted the Protocol on Amendments to the Protocol on Statute of the African Court of Justice and Human Rights (also called Malabo Protcol) one year later. The Protocol has since opened for ratification. ${ }^{500}$

In accordance with section 28A of the Protocol, the African Court of Justice and Human Rights will have jurisdiction on 14 crimes. The broad extension of the court's jurisdiction leads to the need for more personnel resources. Thus, it is envisaged that out of 16 judges, where most actually only serve on a part-time basis on the African Court of Justice and Human Rights, nine will be supposed to work with the International Criminal Law Section. Thus, in accordance with the provisions of the Protocol, seven judges remain available for the General Affairs Section and the Human Rights and Peoples' Rights Section. ${ }^{501}$

aa) Legal issues on the implementation of the Criminal Chamber to the merged Court

The proposed implementation of the Criminal Chamber within the merged African Court raises many legal concerns with regarding the provisions Constitutive Act of the African Union and also the Rome Statute.

First, a legal ground is needed for the AU to establish a Criminal Chamber. Pursuant to Art. 4(h) of the Constitutive Act, African States are empowered to take any measure to prevent the perpetration of an international crime, such as genocide, war crimes, crimes against humanity, if those crimes form a threat to peace and security. Thus, Art. 4(h) of the Constitutive Act can be used as legal basis for the establishment of a Criminal Chamber on AU level.

However, it remains doubtful if the Rome Statute allows the establishment of a regional or rather international criminal chamber other than the ICC. Arts. 1 and 17 of the Statute do not give any implication on that issue. It is however clear that national courts - due to the principle of state sovereignty - do have the right to execute jurisdiction over the above-mentioned crimes. A progressive interpretation of the provisions of the Rome Statute may, therefore, led to a conclusion, that regional courts may confer jurisdiction on crimes in order to close all impunity gaps. ${ }^{502}$

\footnotetext{
499 Maungandize \& du Plessis (2015), 79.

500 Ibid.

501 Ssenyonjo \& Nakitto (2016), 77.

502 Maungandize \& du Plessis (2015), 79.
} 
Pertaining to the crime of genocide, the 1948 Genocide Convention ${ }^{503}$ allows international criminal tribunals to 'prosecute and punish individuals who commit genocide. ${ }^{504}$ Further, the preparation of summoning against Heads of State should be possible if there is a suspicion of Commission of international crimes.

To become an effective instrument, the Criminal Chamber should ensure that immunity is not a ban or mitigating factor with regard to the punishment of Heads of State in Africa. This provision would be in line with Art. $4(\mathrm{~m})$ and (o) of the Constitutive Act, the Genocide Convention, Art. 27 of the Rome Statute and Art. 12 of the Protocol for the Prevention and the Punishment of the Crime of Genocide, War Crimes and Crimes against Humanity.

Lastly, Art. 52(2) of the UN Charter may provide a legal ground for the establishment of such chamber stating ' $[t]$ he Members of the United Nations entering into such arrangements or constituting such agencies shall make every effort to achieve pacific settlement of local disputes through such regional arrangements or by such regional agencies before referring them to the Security Council.'

bb) The implementation of the Criminal Chamber - causing much criticism Even though the establishment of a Criminal Chamber within the African Union would constitute a milestone with regard to international law, the effected transformation of the Chamber could be liable to the political will of African leaders.

Even if the Chamber was implemented, it is not ensured that international crimes will be prosecuted on a free basis. Within the African continent, the influence of African leaders is enormous since peace and security within the continent generally depend on their will. One of the greatest concerns regarding the implementation of the Criminal Chamber, is the decision of the African Union to grant immunity from prosecution for all serving Heads of State and senior officials at the African Court of Justice and Human Rights. This decision is described as one of the 'worst possible signals'. 505

503 The Convention on the Prevention and Punishment of the Crime of Genocide was adopted by the United Nations General Assembly in December 1948. The Convention entered into force in January 1951. It defines legal terms and is the collimation of years of campaigning by the lawyer Raphael Lemkin. All countries, being signatory of the Convention are advised to prevent and punish actions of genocide in war and peacetime. Currently, 143 countries have ratified the Convention, see: Official Website of the United Nations, Treaty Collection: https://treaties. un.org/pages/ViewDetails.aspx?src=IND\&mtdsg_no=XVIII-7\&chapter=18\&clang=_en, (last visited: 11 September 2018).

504 See: Art. VI of the 1948 Convention on the Prevention and Punishment of the Crime of Genocide (CPPCG); see also: Murungu (2011), 1081.

505 M. Kersten, 'What Gives? African Union Head of State Immunity', Justice in Conflict (7 July 2014), available at: https://justiceinconflict.org/2014/07/07/what-gives-african-union-head-ofstate-immunity/, (last visited: 20 March 2017). 
AU leaders argued that the prosecution of Heads of State and Government could undermine the sovereignty, stability, and peace in AU Member States as well as undermined reconciliation and reconstruction and the normal functioning of constitutional institutions. ${ }^{506}$

This amendment of the Protocol on the Statute of the African Court of Justice and Human Rights is, however, inconsistent with the provisions of Art. 4(h) of the AU Constitutive Act which provides for the obligation to protect from massive human rights violations. Furthermore, the decision contravenes the commitment of the African Union towards rejecting and condemning impunity, as per Art. 4(o) of the AU Constitutive Act. Finally, parties to the Rome Statute by approving the amendment with regard to the Criminal Chamber contradicted their 'commitment to combat impunity under the Statute'.$^{507}$ Human Rights Watch and Amnesty International are censorious of this event since this clause violates customary international law and moreover, Heads of State and Government Seniors are not punished for any international crimes that have been committed during their time in office. ${ }^{508}$

Another matter leading to controversial discussion is Art. 46Abis of the Malabo Protocol stating that 'no charges will be commenced or continued before the Court against $[\ldots]$ other Senior State Officials based on their functions, during their tenure of office.' This clause allows the prosecution of a former Head of State. However, the clause may lead to the dilemma that AU leaders may remain in office for a longer time out of fear of prosecution before the International Crimes Chamber. In contrast to the proposed African chamber on international criminal law, the Rome Statute states that the official position of the involved person shall not relieve them from criminal prosecution. ${ }^{509}$

Furthermore, the permanent lack of funding will impair the effective work of the chamber. Since investigations on international crimes require a great variety of resources, it is questionable whether African leaders would generously support the funding of a Criminal Chamber, which could one day arrange the prosecution of the said leaders.

The consequence of the implementation of a wider jurisdiction is that the prosecution of international crimes would lead to the need for immense financial resources. Thus, it needs to be ensured that the Court is staffed with qualified staff with sufficient expertise and technical equipment. Giving an example, the current financial resources of the ICC regarding the prosecution of only three crimes is 'more than 14 times of the African Court without a criminal component; and just about double

506 Ssenyonjo \& Nakitto (2016), 73.

507 B. D. Gezahegn, 'The International Criminal Court and the African Union: A Deadlock where Power Politics Paralyzes International Law', Human Rights Brief, (4 January 2015), available at: http://hrbrief.org/hearings/the-international-criminal-court-and-the-african-union-adeadlock-where-power-politics-paralyzes-international-law/ (last visited: 20 March 2017). M. Abaya, 'No Place for Immunity: The Arguments against the African Criminal Court's Art. 46, BIS', 30 Temp Int'l \& Comp LJ (2016), 189, 190. 
the entire budget of the AU. ${ }^{510}$ In this connection, the planned reduction of the judges being involved may lead to the conclusion that human rights jurisdiction will be limited in favor of international crimes. It is doubtful that the nine judges, who only serve on a part-time basis, will work on the international crimes effectively. In comparison, the ICC currently consists of 18 full-time serving judges, who only work on four different international crimes. ${ }^{511}$

Despite all listed concerns, the establishment of the Criminal Tribunal for Rwanda and the Special Court for Sierra Leone, ${ }^{512}$ indicated the trend towards the establishment of international courts on the African continent. ${ }^{513}$

In addition to that, not every African country is party to the Rome Statute; and thus, no co-operation with the whole African continent and the ICC is possible.

Amongst others, one important advantage of the establishment of the Criminal Chamber might be that the African Union has the competence to define the jurisdiction of the Court. For instance, the AU extended the jurisdiction of the Court to crimes common in Africa, such as election-rigging, unconstitutional change of governments, acts of terrorism, drug trafficking, and piracy. The ICC does not have jurisdiction over the above-mentioned crimes.

Finally, the impression arises that the AU wants to protect some of the Heads of State and Government suspected for the committing international crimes and facing prosecution initiated by the ICC. ${ }^{514}$

The African Commission, however, states that the planned expansion of the jurisdiction of the African Court of Justice and Human Rights does not have its grounds in the arrest warrants issued by the ICC and the resultant anti-ICC sentiment with many of AU governments. ${ }^{515}$ In fact, the proposal is based on three issues. First, some countries misused the principle of universal jurisdiction. Second, the African Union wants to seek issues that came up with the process against the former

510 Murungu (2011), 1085.

511 Ssenyonjo \& Nakitto (2016), 76.

512 The Special Court for Sierra Leone was set up in 2002 as result of a request to the United Nations in 2000 by the Government of Sierra Leone for a 'special court' in order to address serious crimes against civilians and UN Peacekeepers committed during the civil war (1991-2002). The Court was established to 'prosecute persons who bear the greatest responsibility for serious violations of international humanitarian law and Sierra Leonean law'. Amongst others, the Court has jurisdiction on persons committing crimes on humanity against civilians. Finally, in 2012, the former President of Sierra Leone, Charles Taylor was the first president, which become convicted for his party in war crimes. See: L. Gberie, 'Special Court of Sierra Leone rests - for good', AfricaRenewal (April 2014), available at: https://www.un.org/africarenewal/magazine/april-2014/ special-court-sierra-leone-rests-\%E2\%80\%93-good, (last visited: 9 September 2018).

513 Murungu (2011), 1083.

514 Maungandize \& du Plessis (2015), 80.

515 Murungu (2011), 1087. 
President of Chad, Hissène Habré. And third, Art. 25(5) of the African Charter on Democracy, Elections and Governance requires that the African Union formulate 'a novel international crime of unconstitutional change of government. ${ }^{516}$

Lastly, the establishment of a Criminal Chamber consequently leads to the question about the relationship between the ICC and the African Court of Justice and Human Rights. It appears to be unlikely that African States that signed the Rome Statute will be able to meet the financial obligations with regard to both courts. Kenya, offering the payment of US\$ 1 million in order to establish the Criminal Chamber, may have an undue influence on the Criminal Chamber of the African Court of Justice and Human Rights. ${ }^{517}$

\subsubsection{Conclusion on the establishment of the Criminal Chamber within the African Court of Justice and Human and Peoples' Rights}

In general, the establishment of a Criminal Chamber could provide for a better protection of human rights in Africa - as war crimes such as genocide, usually involve gross violations of human rights, such as the violation of the respect of dignity and the right to life as well as to physical integrity. The establishment of such a Chamber - taking into consideration the establishment of other international courts such as the International Criminal Tribunal for Rwanda - does not appear to be curious on the first sight.

The implementation of a Criminal Chamber within the merged Court is, however, going to be a long-term project. This results from the fact that the ratification by the single States generally takes a lot of time. ${ }^{518}$ Consequently, there might be no impact on recent cases before the ICC affecting countries such as the Central Republic of Africa, Ivory Coast, the Democratic Republic of Congo, Libya, Kenya Sudan and Uganda. ${ }^{519}$

However, one main issue is that the costs of a Criminal Chamber will by far exceed the costs of the other two sections. Taking into consideration current examples, such as the International Criminal Tribunal for Rwanda, the biennial budget was about US\$ 270 million in 2006-2007. In comparison, the budget of the African Court on Human Rights was a mere US\$ 6 million. ${ }^{520}$

516 Bellelli (2010), 80 .

517 Ibid.

518 D. Deya, 'Is the African Court worth the wait-Pushing for the African Court to exercise jurisdiction for international crimes 2012', Open Society Initiative for Southern Africa (March 2012) available at: http://www.osisa.org/openspace/regional/african-court-worth-wait, (last visited: 20 March 2017).

519 Maungandize \& du Plessis (2015), 80.

520 M. W. Martin \& B. Jurgen, 'Proposed International Criminal Chamber Section of the African Court of Justice and Human Rights: A Legal Analysis, Notes and Comments', 37 S Afr YB Int'l L 1 (2012), 248, 261. 
Concerning the provided Malabo Protocol, the merged Court will consist of three chambers, the Pre-Trial Chamber, a Trial Chamber, and an Absolute Chamber. Moreover, a Witnesses Unit, Defence Unit, Defence Counsel as well as a Detention Management Unit will be established. The sheer establishment of those institutions will already take a long time and will be very costly. ${ }^{521}$

Furthermore, it has been argued many times now that the implementation of such a chamber would lead to a negative impact on human rights adjudication, inter alia due to the costs that do arise through the establishment of the Criminal Chamber. The AU sooner or later will reduce the budgets of other human rights institutions of the continent ${ }^{522}$ Another negative impact is that the Malabo Protocol does not provide for the appointment of further judges. Thus, the same judges as with the African Court of Justice and Human Rights will be responsible for the extended jurisdiction of the Court.

One solution to prevent negative impacts on human rights jurisdiction at the African Union level could be the implementation of a separate court solely for international criminal justice.

However, regarding the decisions facing the impunity of Heads of States and Governments as well as their seniors and due to the financial impacts, the Criminal Chamber may not become a strong human rights system. It appears most unlikely that African Governments would push towards an effective criminal law section which would then finally affect themselves. Especially, if African countries eventually turn away from the ICC, the effective prosecution of international crimes will be doubted. 523

However, it remains to be seen if judges would take the chance to strengthen human rights or if they would rather depend on the will of the political elite of the African continent. ${ }^{524}$ The former option remains unlikely since African leaders decided to grant immunity to Heads of State and Government. African States, however, need to ensure their obligations arising under the principle of universal jurisdiction over international crimes - especially if they are Member States to the Rome Statute. ${ }^{525}$ Finally, African leaders should rather improve their relationship with the ICC and thus fight international crimes together with the ICC. ${ }^{526}$ Since Africa is notorious for adopting treaties but not to ratify them, it is still doubtful if this Criminal Chamber will ever materialize.

521 Art. 3 of the 2014 Protocol on Amendments to the Protocol on the Statute of the African Court of Justice and Human Rights.

522 Murungu (2011), 1086.

523 D. N. Nsereko, 'The International Criminal Court and Africa', in M. Sssenyonio (ed), The African Regional Human Rights System; 30 Years after the African Charter on Human and Peoples' Rights (2012), 354.

524 Ssenyonjo \& Nakitto (2016), 76.

525 Murungu (2011), 1088.

526 Martin \& Jurgen (2012), 268. 


\subsubsection{The Pan-African Parliament (PAP) - capable to guarantee human rights?}

Alongside the judicial and quasi-judicial arms of the AU, the Pan-African Parliament (PAP) was established with the intention to represent the African people on the regional level. Thus, the PAP aims ot ensure popular participation within the level of the AU. The Pan-African Parliament was founded in order to alleviate criticisms made with regard to the lack of both popular participation and democratic legitimacy of the African Union. ${ }^{527}$ Eventually, mainly African leaders influenced the formation of the Parliament. ${ }^{528}$

The Protocol establishing the Pan-African Parliament was adopted in 2000, whereas the inaugural session of the Pan-African Parliament (PAP) occurred at the United Nations Economic Commission for Africa Conference Centre in Addis Ababa, Ethiopia on 18 March $2004 .{ }^{529}$ The establishment of this kind of Parliament was proposed in 1991, during the adoption of the Abuja Treaty under Art. 7(1)(c). ${ }^{530}$ In 1999, with the adoption of the Sirte Declaration, the Assembly of Heads of State and Government called for the effective establishment of the institutions that were mentioned in the Abuja Treaty. ${ }^{531}$ Art. 5(1)(c) of the Constitutive Act provides the Pan-African Parliament to become an official organ of the AU.

As a consequence of the Extraordinary Session of the Assembly of the Heads of State and Government in July 2000, the Protocol to the Treaty establishing the Pan-African Parliament was adopted. With the ratification of the Protocol by 24 States, it became effective in November 2003. ${ }^{532}$ Under the provisions set out in the Preamble of the Protocol on the Pan-African Parliament, the Parliament is entitled to 'provide a common platform for African peoples and their grass-roots organisations to be more involved in discussions and decision-making on the problems and challenges facing the continent.'

The seat of the Pan-African Parliament was first in Addis-Ababa but was later moved to Midrand, South Africa. ${ }^{533}$

\footnotetext{
527 Viljoen (2007), 184.

528 T. Demeke, 'The New Pan-African Parliament: Prospects and Challenges in View of the Experience of the European Parliament', 4 Afr Hum Rts LJ 1 (2004), 54.

529 B. R. Dinokopila, 'The Pan-African Parliament and African human rights actors, civil society and national human rights institutions: the importance of collaboration', 13 Afr Hum Rts LJ 2 (2013), 302 et seq.

530 Demeke (2004), 54.

531 Viljoen (2007), 184.

532 Demeke (2004), 54.

533 R. F. Oppong, Legal Aspects of Regional Integration in Africa (2011), 170.
} 


\section{a) The composition of the Pan-African Parliament}

The Pan African Parliament consists of representatives of the parliaments of the African Union Member States. It was implemented in the institutional structure of the AU to 'ensure the full participation of African peoples'. With the establishment of the Parliament, African citizens are supposed to participate in the discussions and decision-making processes that apply to the whole African continent. ${ }^{534}$ The Parliament is also entitled to enhance the level of democracy, constitutionalism and the rule of law. ${ }^{535}$

The Parliament consists of five members per country. At least one of the Members of Parliament of each State must be a woman, as set out by Art. 4(2) of the Protocol. ${ }^{536}$ According to the provisions of Art. 7 of the Protocol, holders of executive and judicative positions are explicitly excluded from the membership in the Pan-African Parliament. ${ }^{537}$

The sitting members of the national Parliaments generally elect the members of the Pan-African Parliament. States that are dominated by one political party, might then become represented in Pan-African Parliament by members of the governing party. ${ }^{538}$ On one hand, a continent-wide direct election of PAP members would, thus, lead to a better representation of political minorities. ${ }^{539}$

On the other hand, the fact that the members of the Pan-African Parliament are drawn from national parliaments leads to a closer relationship between national parliaments and the PAP. Members of the PAP can forward their knowledge to the national parliaments with regard to $\mathrm{AU}$ law when it comes to the implementation of national law. ${ }^{540}$

Under Art. 8(1) of the Protocol, members of the PAP enjoy immunity within the territories of the African Union Member States while exercising their function with accordance to the provisions of the General Convention on the Privileges and Immunities of the OAU and the Vienna Convention on Diplomatic Relations. Members of Parliament thus shall not be liable for any civil or criminal proceedings, arrest, imprisonment and damages with regards to any statement within or outside of the Parliament. ${ }^{541}$

\footnotetext{
534 Viljoen (2007), 184 et seq.

535 Demeke (2004), 54.

536 K. Magliveras \& G. Naldi, 'The Pan-African Parliament of the African Union: An Overview', 3 Afr Hum Rts LJ (2003), 222, 225.

537 Viljoen (2007), 185.

538 Ibid.

539 Demeke (2004), 67.

540 Oppong (2011b), 170.

541 Magliveras \& Naldi (2003), 226.
} 
In case of any upcoming vacancies of seats owing to death, resignation, inability to perform one's duties for reasons of physical or mental incapacity, removal on grounds of misconduct, ceasing to be a member of the national legislature, being recalled by the national legislature, and withdrawal of the parliamentarian's Member State from the AU, Art. 5 of the Protocol provides for a filling process. ${ }^{542}$

In order to prepare their decisions, the PAP may establish various Committees. Amongst them, a Justice and Human Rights Committee was installed to fulfill the human rights mandate of the Parliament more effectively. ${ }^{543}$

\section{b) Functions and powers of the Pan African Parliament (PAP)}

Parliaments on the regional level, in general, provide for limited powers and are not capable of adopting laws with regard to every topic.

A Parliament is normally entitled to exercise legislative, supervisory and budgetary tasks. In both, regional a national level, parliaments are entitled to play a fundamental role and to represent the will and views of the population.

In accordance with Art. 3 of the Protocol to the Pan-African Parliament, objectives of the Parliament inter alia include the implementation of policies of the AU, promotion of human rights and democracy, the encouragement of good governance, transparency and accountability in its Member States, the promotion of peace, stability, security and economic recovery as well as facilitating co-operation among regional economic communities.

The PAP is given the task to ensure the full participation of African peoples concerning regional integration within the continent. Thus, the PAP is entitled to provide a platform for African peoples and NGOs, for them to become involved in the decision-making process on issues facing the continent. ${ }^{544}$

Since its establishment, the PAP was solely an advisory and consultative entity. Only at a later point of time, the Pan African Parliament will be vested with decision-making and legislative powers, which will need to be specified by the Assembly of Heads and State. This development would be useful for the harmonization of laws within the African continent. ${ }^{545}$

At this juncture, the Parliament does not hold effective decision-making powers with regard to important areas such as questions on the budget of the African Union. The PAP is, however, mandated to discuss recommendations regarding the African Union budget as well as the harmonization and coordination of laws of the several Member States, policies, measures, programs and activities on the several regional Economic Communities. ${ }^{546}$

\footnotetext{
542 Ibid.

543 Viljoen (2007), 185.

544 Magliveras \& Naldi (2003), 224.

545 Viljoen (2007), 185.

546 Dinokopila (2013), 307.
} 
In fact, according to Art. 11 of the Protocol to the Pan-African Parliament the PAP has the power to give advisory opinions regarding the transformation of the objectives of the AU, including the promotion of democracy, good governance, human rights and the rule of law. Moreover, according to Art. 11(9) of the Protocol, the PAP may perform such functions that seem appropriate in order to achieve its objectives. $^{547}$

During its second session, the Pan African Parliament concluded that it has an 'oversight role' and asked the Committee on Rules, Privileges and Discipline to 'make specific recommendations' about how the Pan African Parliament should oversee the African Union. As of now, the mandate is limited to deliberating on issues and adopting reports and non-binding recommendations. ${ }^{548}$

During its sessions, the Pan African Parliament issued many resolutions and recommendations. However, they generally have been very brief, poorly drafted and insufficiently substantiated and therefore are open for enormous improvements. However, these resolutions include human rights matters, such as a call for those countries which have not yet done so, to ratify the Protocol on Women's Rights in Africa and an appeal stating that the proposed merger of the African Court of Justice and the African Court on Human and Peoples' Rights should not 'compromise the immediate establishment' of the latter Court. ${ }^{549}$ Since its establishment, the PAP has carried out a number of human rights oriented workshops and symposia and was involved in several election observer missions throughout the continent. Furthermore, the PAP issued several resolutions in order to encourage AU Member States to ratify human rights-related treaties. ${ }^{550}$

In 2004, when the conflict in Sudan began, the Parliament decided to send a so-called fact-finding mission to the Darfur region in order to receive more knowledge with the realities within the region and to report facts to the PAP. Therefore, seven Members of the Pan-African Parliament where chosen to visit Sudan. The PAP later recommended that the so-called Joint Commission, being mentioned in the Humanitarian Cease-Fire Agreement should become established. It should work closely with the African Commission, in order to effectively address possible human rights violations. ${ }^{551}$

547 It needs to be noticed, that in case of misuse of the powers by the Pan-African Parliament, any member of the African Union is allowed to bring an action before the African Court of Justice with accordance to 18(3)(a) of the Treaty. Moreover, an action could be brought before the African Court of Justice under the provisions of Art. 19(1)(d) of the Protocol of the African Court of Justice of the African Union.

548 Viljoen (2007), 185.

549 Ibid.

550 Dinokopila (2013), 311.

551 Recommendation on the Pan-African Parliament Peace Mission to Dafur, AU Doc. PAP Rec. (001/05), paras g. and h. 
The issue of limited powers of the Pan African Parliament is comparable with the General Assembly of the United Nation and other principal organs. The UN General Assembly only has limited powers and cannot interfere effectively if the UN Security Council refuses to intervene in disputes. ${ }^{552}$

\subsubsection{Conclusion on the Pan African Parliament}

It is beyond dispute that the implementation of the Pan-African Parliament is a great achievement for the African continent regarding the popular participation at the regional level. ${ }^{553}$

However, the influence of the PAP is not very effective and thus, the Parliament does not yet provide for a greater level of legitimacy of the AU.

During the session of the Pan-African Parliament in May 2017, the President of the PAP Hon. Nkodo Dang stated that since the PAP does not have a mandate to impose sanctions or penalties it fails with regards to the promotion of democracy and the rule of law within Africa. ${ }^{554}$

For the Pan-African Parliament to become more effective, it is inter alia very important to ensure greater publicity all over the continent about its work. The PAP should, therefore, collaborate on a higher level with the rest of the key organs within the African Union, such as the Executive Council or the African Commission. ${ }^{555}$ Furthermore, the PAP should focus on the collaboration with NGOs, as they are the most active bodies on the continent when it comes to ensuring human rights protection through submission of claims and/or communications.

Furthermore, African citizens are not well represented by the Pan-African Parliament. Even though the representation for each Member State has to reflect the political diversity of a country, ' $[\ldots]$ there appears to be no restraint on an autocrat manipulating the nomination process. ${ }^{.} 56$

As per opinion of Frans Viljoen, the possibility for the PAP to become a fully working forum on human rights is quite remote at the moment. The achievement of this goal is dependent on the political will of the political leaders within the continent. Again, decisions concerning the funding of the PAP that are within the mandate of the Assembly of Heads of State and Government have a great influence on the work of the Parliament. ${ }^{57}$

\footnotetext{
552 Oke (2013), 123 et seq.

553 Demeke (2004), 72.

554 PAP, PAP President urges journalists to lobby for ratification of Malabo Protocol (21 May 2017), available at: http://www.panafricanparliament.org/news/283-pap-president-urgesjournalists-to-lobby-for-ratification-of-malabo-protocol, (last visited: 7 July 2017).

555 B. R. Dinkopila, 'The Pan-African Parliament and African human rights actors, civil society and national human rights institutions: the importance of collaboration', 13 Afr Hum Rts LJ (2013), $302,323$.

556 Magliveras \& Naldi (2003), 226.

557 Viljoen (2007), 189.
} 
In addition, for the Parliament to become a fully working Parliament, it is very important, that the members of the Parliament are elected by direct suffrage. However, the achievement of this goal is very remote too, since not even on ECOWAS level - as will be explained later - the implementation of direct suffrage appears possible due to technical and financial issues.

Moreover, the Parliament should ensure the presence of opposition from each African country to be represented within the Parliament. Additionally, the enhancement of strong national Parliaments is of great importance for the Pan-African Parliament to become a strong mandate. ${ }^{558}$

Lastly, many parties to the Protocol on the Parliament cannot afford to enforce the decisions issued by the Parliament. ${ }^{559}$ Thus, countries should find a solution on how to effectively deal with such issues.

Besides that, comparable to those of subregional parliaments, the PAP Rules of Procedure should include provisions which ensure the collaboration with NGOs. ${ }^{560}$

However, not only the African Union is criticized due to its lack of legitimacy. Besides the African Union many other international bodies, such as the WTO but also the European Union do not provide parliamentary systems which ensure their legitimacy.

For instance, the UN and its organs, as well as the NATO, are influenced by e.g. the government of the United States and other 'superpowers'. ${ }^{561}$

Another example may be the World Trade Organization (WTO). The WTO is often criticized as a super-government lacking in legitimacy. This assumption comes from the fact that WTO rules have the standing as supra-constitutional rules which have superior force regarding national regulations. Furthermore, the WTO Dispute Settlement may, by virtue of its rulings, force a State to comply with the WTO provisions. In general, the WTO does not receive any democratic input and thus democratic authority is still determined through its Member States. Furthermore, the Dispute Settlement does not receive any legislative checks despite its supranational powers. ${ }^{562}$

The WTO is - despite its extraordinary powers - a simple international organization, which in general does not want the public to participate at its meetings and thus makes its decisions in secret.

On the European level, through the adoption of the Lisbon Treaty, the competences of the European Parliament were strengthened. Under Art. 289 (1) of the Treaty on the Functioning of the European Union (TFEU), legislative acts shall

\footnotetext{
$\overline{558 \text { Demeke (2004) }}, 73$.

559 Ibid.

560 Ibid., 319 et seq.

561 Oke (2013) 134.

562 J. Atik, 'Democratizing the WTO Symposium: Global Trade Issues in the New Millenium', 33 Geo Wash Int'l L Rev (2001), 451, 452; see also: G. C. Shaffer, 'The World Trade Organisation under Challenge: Democracy and the Law and Politics of the WTO's Treatment of Trade and Environment Matters', 25 Harv Envt'l L Rev 1 (2001), 1.
} 
be jointly adopted by the Parliament and the Council. The Commission is mandated to issue proposals on legislative acts. The Council and the Parliament have equal rights and consent of both institutions is needed in order for a proposal to become legally binding. The Parliament generally until this day, lacks the right on initiative. ${ }^{563}$ In accordance with Art. 14(2) of the Treaty of the European Union (TEU), the Members of Parliament shall be elected by the citizens of the European Union, whereas the representation of each country within the Parliament shall be determined on a regressive-proportional basis. Thus, taking into consideration the developments on the EU, African politicians demand for the establishment of a fully-fledged Parliament on the level of the African Union. ${ }^{564}$

Gertrude Mongella, President of the Pan-African Parliament (PAP) thus, inter alia noted 'legislation is only a small fraction of the activities of a parliament. A strong parliament is one that plays an effective oversight role [...]. ${ }^{565} \mathrm{On}$ the other hand, according to the definition of the Commonwealth Parliamentary Association (CPA), a parliament is a law-making assembly constituted under the laws of a nation at ...the national, state, province, territory or dependency level functioning within a parliamentary system ${ }^{566}$ Nevertheless, still today many regional parliaments exist worldwide, holding only limited consultative or advisory mandates, with no real power. ${ }^{567}$ The Pan-African Parliament, unfortunately, is one of them since it does not hold any binding or oversight powers. There are - throughout the continent - many voices that favor the establishment of a fully-fledged Parliament.

\subsection{Conclusion on the Human Rights wing of the African Union (AU)}

In summary, the African Union (AU) entertains several institutions and instruments with the promotion of the rule of law tasks and the therewith-related protection of human rights. Besides that, the PAP serves as the institution which aims to ensure the popular protection. The core weakness of the system remains the dependence

563 C. Tomuschat, 'Lisbon Treaty' in R. Wolfrum (ed), Max Planck Encyclopedia of Public International Law (2011), para. 14.

564 For more details see: J. Ott; Das Europäische Parlament als Parlament (2016).

565 SARPN, A dialogue with Ambassador Gertrude Mongella, President of the Pan African Parliament (14 September 2004), available at: http://www.sarpn.org/documents/d0001076/ (last visited: 14 August 2016).

566 T. Musavengana, The proposed SADC Parliament - Old wine in new bottles or an ideal whose time has to come? (2011), 25.

567 Ibid. 
of its efficacy on the political will of African leaders. Another issue is the financial dependence of the African court system on funding by European and American funders, which may undermine its legitimacy. ${ }^{568}$

The African Union system, including the African Commission, have between 2009 and 2016 heard 88 cases, whereof twenty-four cases resulted in a judgment confirming or establishing human rights violation. However, only very few judgments have been enforced by the respective State.

The proposed African Court of Justice and Human Rights provides for a broad mandate on human rights jurisdiction but also on international crimes. However, controversially it also affords immunity to the Heads of State and Government. The proposed Criminal Chamber within the Court, competent to decide international crimes on the African level, may also complicate the work of the International Criminal Court. ${ }^{569}$ The recent situation however allows for the hope that especially NGOs extend their capacities in order to push towards better recognition of the principle of the rule of law. Furthermore, it is hoped that politicians sitting in the Assembly support the enforcement of Courts' decisions within the continent. Such outcomes may lead to the improvement of the protection of human rights throughout the whole African continent. However, as of yet, no such hopes have been realized or indeed there are no signs that they will be in the foreseeable future. Other than that, the merger of the African Court of Justice and the Human Rights Court as well as the implementation of a Criminal Chamber being able to hear international criminal law related cases remains crucial.

Besides the court system, the Pan-African Parliament plays an unsatisfactory role regarding human rights protection. Apart from the need to create partnerships with the other human rights institutions within the African Union, the PAP also has to create partnerships with members of civil societies, which are mostly unaware of its work. ${ }^{570}$

However, despite all criticism, recent years show that human rights institutions within the continent - especially the African Commission and the Court, through recent communications and judgments try to ensure the protection of the rule of law within the continent in granting compensation on victims of human rights violations or the expressively extension of jurisdiction on other human rights instruments than the African Charter.

\footnotetext{
568 D. Abebe, 'Does International Human Rights Law in African Courts Make a Difference?', 56 Va J Int'l L (2016), 564.

570 Dinokopila (2013), 323.
} 


\subsection{The economic wing of the African Union (AU)}

Apart from the particular human rights wing, the African Union - similar to all regional treaties pursues goals advancing the economic integration within its Member States. Since Africa still consists of many countries with very small and weak economies, an improvement of economic integration is desirable for the whole continent. However, lack of infrastructure and competition impede such process within the continent. Moreover, the issue of corruption in most African countries slows down the process. However, during the last decades, the AU and the OAU set up similar institutions in order to deepen economic integration within the continent. The achievement of a reasonable standard of life interlinks with the protection of human rights and thus the rule of law. After all, some of the rights provided in the African Charter, such as the right to education will only become realized together with the advancement of the standard of living.

\subsubsection{New Partnership for Africa’s Development (NEPAD)}

In 2001, shortly before the transition to the African Union, African leaders began with the implementation of the New Partnership for Africa's Development (NEPAD).

The OAU Assembly of Heads of State and Government in July 2001 adopted the document establishing the NEPAD framework. The role of NEPAD was to identify problems, pinpoint solutions and where needed, exert high-level political pressure to promote change. ${ }^{571}$ NEPAD became an integral part of the African Union (AU) ${ }^{572}$ The NEPAD document primarily focuses on economics including capital flows, market access, science and technology. ${ }^{573}$ Thus, NEPAD is not supposed to be a human rights document as such, it is however seen as 'human rights friendly' document. It does not, however, refer to the institutions within the AU promoting and protecting human rights. ${ }^{574}$ The NEPAD document, above all, is focused on economic issues such as 'bridging the infrastructure gap as well as the digital divide; on agriculture, science, and technology; capital flows; and market access. ${ }^{2} 75$ Furthermore, Paragraph 68 of the NEPAD document refers to the United Nations Millennium Goals (MDGs) stating that the aim of NEPAD would be to lift the African continent out of poverty and to achieve a $7 \%$ growth rate. In 2015

571 M. Killander, 'The African Peer Review Mechanism and Human Rights: The First Reviews and the Way Forward', 30 Hum Rts Q (2008), 42.

572 H. A. Hammed \& S. E. Kabo, 'African Peer Review Mechanism and Crisis of Good Governance in Africa', 19 JL Pol'y \& Globalization (2013), 14.

573 B. Manby, 'The African Union, NEPAD, and Human Rights: The Missing Agenda', 26 Hum Rts Q 4 (2004), 983, 989.

574 S. Gumedze, 'The Nepad and Human Rights Current Developments', 22 S Afr J Hum Rts 1 (2006), 144, 156.

575 Manby (2004), 988 et seq. 
the United Nations Millennium Goals were replaced through the Sustainable Development Goals - inter alia aiming to ensure that everyone is released from poverty until 2030. ${ }^{576}$

Despite the economic character of the paper, NEPAD provides for six human rights clauses. ${ }^{577}$ They are not, however, neither legally binding nor operative but may give an inspiration to African leaders. ${ }^{578}$ The NEPAD document recognizes that peace, security, democracy, good governance, human rights and a sustainable economic management improve the development of the continent. ${ }^{579}$

In order to promote good governance, the NEPAD Implementation Committee met in Rome in 2002 and adopted the Declaration of Democracy, Political, Economic and Corporate Governance as well as the African Peer Review Mechanism (APRM), which sets out the APRM process. The APRM is a self-monitoring mechanism to which the governments of African States agree to accede to voluntarily. ${ }^{580}$

In the following meeting held in 2003 in Abuja, Nigeria, a Memorandum of Understanding on the African Peer Review was approved in order to form a framework for the formal accession to APRM. Four years later, the Memorandum of Understanding was signed by 27 States.

The APRM deals with four different areas of governance: democracy and political governance, economic governance and management, corporate governance, and socio-economic governance. African States may undergo a review which is then discussed in the African Peer Review Mechanism Forum. As of yet, not too many States have made use of the review process. ${ }^{581}$

The process of the establishment of a peer review is not unique. The Organization for Economic Co-operation and Development (OECD) has been the first institution which was implemented with regard to peer review. Furthermore, other organizations such as the International Monetary Fund (IMF), the EU, and the WTO perform peer reviews.

NEPAD is one of the most important achievements regarding the African development policy in the last decades. It aims to make it possible for African Nations to work together in matters regarding the promotion of peace, stability, democracy and sound economic development. The link between development and good governance is inseparable since only the promotion and recognition of the rule of law leads to more development. ${ }^{582}$

\footnotetext{
576 Introduction to the 2015 Sustainable development Goals of the United Nations.

577 Paragraphs 7, 49, 71, 79, 80, 180.

578 Gumedze (2006), 157.

579 Manby (2004), 989.

580 K. Appiagyei-Atua, 'Bumps on the Road: A Critique of How Africa Got to NEPAD', 6 Afr Hum Rts LJ (2006), 524, 544.

581 Gumedze (2006), 153 et seq.

582 Hammed \& Kabo (2013), 14 et seq.
} 
The APRM is designated to periodically review the progress of the implementation of the aims of NEPAD. The mechanism seeks to help African States improve governance, political and economic standards and standards being mentioned in the Declaration of Democracy, Political, Economic and Corporate Governance. ${ }^{583}$

The level of adherence is regularly determined in accordance with the principles of good governance set out by the AU and the NEPAD. The review process is regularly done under the supervision of the AU. The APRM base document further states that the report shall be distributed to the key regional and subregional institutions, such as the PAP and the African Commission. ${ }^{584}$

In theory, most African governments recognize human rights as such, since all African constitutions include a bill of rights. However, in many cases, the bills are not worth the paper they are written on. NEPAD itself recognizes the four governance areas mentioned above, for which human rights are relevant. For instance, Objective 3 under the Democracy and Political Governance in the respective Questionnaire is entailed to 'promote and protect economic, social, cultural, civil and political rights, as enshrined in all African and international human rights instruments. ${ }^{585}$

NEPAD, on the one hand, was strongly welcomed on the international level, however one of the most important weaknesses is that no African Parliament was involved in any consultation on the drafting process. The most efficient way to involve African citizens would have been to hold a referendum. Due to the financial restrictions and other difficulties such a referendum this would have been difficult to implement. However, the participation of national parliaments - representing at least the majority of African citizens would give much more legitimacy to the institution. The ratification process comes in contrast with the principles laid down in the papers since the papers promote a greater participation of the African citizens. ${ }^{586}$

Furthermore, the engagement with civil societies remains quite low. ${ }^{57}$

The APRM system finally offered a good possibility to discuss the recognition of the rule of law in African States. However, not all States do finally submit their reports, as the mechanism remains voluntary. Furthermore, a possible the discrepancy with a State's constitution does not invoke any consequence for the involved State. Acceding the NEPAD does not require African States to accede APRM in order to implement the obligations under the Declaration of Democracy, Political, Economic and Corporate Governance. Therefore, this mechanism may not exert any pressure of African governments to respect the principle of good governance and thus the relating thereto human rights. ${ }^{588}$

\footnotetext{
583 Manby (2004), 991.

584 Killander (2008), 53.

585 Ibid.

586 Gumedze (2006), 147.

587 Manby (2004), 1004.

588 Gumedze (2006), 166.
} 


\subsubsection{The African Economic Community (AEC)}

In order to promote economic integration within the continent, the OAU established the African Economic Community (AEC).

Since the AEC was entitled to become an integral part of the OAU, most of the AEC Treaty provisions that deal with organs procedures and modalities of operation are similar to the OAU Treaty. Even some of the main institutional bodies, such as the Assembly of Heads of State and Government, the Council of Ministers and the Economic and Social Commission were shared between the OAU and AEC. ${ }^{89}$

Art. 4 of the AEC Treaty marks the aims of the Organization stating (a): the promotion of economic, social and cultural development and the integration of African economies in order to increase economic self-reliance and an indigenous and self-sustained development; (b) to establish, on a continental scale, a framework for the development, mobilization and utilization of the human and material resources of Africa in order to achieve a self-reliant development; (c) to promote co-operation in all fields of human endeavor in order to raise the standard of living of African peoples and maintain and enhance economic stability, foster close and peaceful relations among Member States and contribute to the progress, development and the economic integration of the continent; and (d) to co-ordinate and harmonize policies among existing economic communities in order to foster the gradual establishment of the Community.

Moreover, Art. 4(2) of the Treaty states how the objectives of the Treaty are to be achieved - namely through the abolition of non-tariff barriers among the Member States in order to create a free trade area; the relaxation of qualitative and administrative restrictions as well as the gradual abolition of a common trade policy. Furthermore, Member States are requested to eliminate customs duties as well as all other non-tariff barriers and require the adoption of a common external customs tariff. 590

The integration of the AEC was supposed to be achieved within six stages, which should not exceed a period of 34 years. Each stage implemented different activities to be transposed. Art. 6(2) states that the first step is to strengthen already existing economic communities and to establish communities in areas where none exist. The second step is the stabilization of tariff and non-tariff barriers, as well as customs duties and internal taxes. The third step the AEC Treaty scheduled is the establishment of free trade areas where the adoption of a common external tariff is expected. Afterward, the Treaty provides for the furtherance of the customs union and then anticipates the establishment of the African Common Market. If one of the listed periods should exceed the contemplated time frame, the Assembly of Heads of State and Government may extend the time frame. ${ }^{591}$

\footnotetext{
589 Heyns et al (2003), 258.

590 See: Arts. 30, 31 and 32 of the 1991 Treaty Establishing the African Economic Community.

591 M. Ndulo, 'Harmonisation of trade laws in the African Economic Community', 42 Int \&

Comp Law Qrt (1993), 106.
} 
One of the important steps of the establishment was the 'amalgamation of the RECs'. Hence, the Treaty establishing the AEC did not perceive the RECs as rivals but rather beheld them as 'key partners and in fact as building blocks of economic integration on the continent. ${ }^{592}$ The subregional bodies were then contemplated to become the operational arm of the AEC Community. ${ }^{593}$

African leaders already stated in the 1980 Lagos Plan of Action, the Special United Nations Session on Africa in 1986 that regional co-operation would lead to greater development among the African continent. However, the economic nationalism, until now, limits the achievements of regional integration. ${ }^{594}$

However, the question of the judicial identity of the AEC remains a mystery: due to the provisions of the General Convention on Privileges and Immunities, the Organization of African Union - now the AU - provides for judicial personality. Moreover, all RECs provide for a legal personality due to their founding treaties. The AEC may be endowed with legal personality due to Art. 98(2), which states that being competent to become the legal representative of the AEC, the Secretary-General may, on behalf of the AEC, enter contracts and be part of judicial proceedings. ${ }^{595}$ Furthermore, the AEC Treaty states clearly that the AEC is an integral part of the AU. It is however not necessary to ratify both, the AU and the AEC Treaty. It appears that the AEC is the economic leg of the AU. ${ }^{596}$

Oppong, however, criticizes that the adoption of the AEC in the AU does lead to a mixing of political and economic unification, which already started when Art. 98 (1) of the AEC Treaty stated that the AEC 'shall become an integral part of the [OAU]'. Art. 99 of the AEC further stated that the AEC treaties and protocols shall become an integral part of the OAU Charter. Neither the AU Treaty nor the AEC Treaty gave any further information on the meaning of this provision. The provision, however, led to the development that the OAU organs - and now the $\mathrm{AU}$ organs - co-operated in order to perform the provisions of the AEC Treaty even though they were not structured in to fulfill the needs of regional integration. ${ }^{597} \mathrm{On}$ the other hand, the merger of both institutions excludes any duplications, focuses on the efficiency of the institutions and reduce financial costs. ${ }^{598}$

Furthermore, since the adoption of the Protocol on the African Court of Justice and Human Rights in 2008, matters of human rights and economic integration are to be mixed all together in the same institution. Additionally, most individuals within the continent are still unable to submit claims before the African Court of Justice. This fact makes it nearly impossible to raise disputes for the most important

592 J. Senghor, 'The Treaty establishing the African Economic Community: an Introductory Essay', 1 African Yearbook of Int'L (1993), 183, 192.

593 Ibid.

594 Ndulo, (1993), 105.

595 Oppong, (2011b), 70.

596 Ibid.

597 Oppong (2011a), 6 et seq.

598 Senghor (1993), 190. 
parties of the integration process - traders, investors and corporate bodies. Thus, individuals who are mostly responsible for the push for regional integration will not be involved in the process which may impede the integration process all over the continent. $^{599}$

The unification of all RECs to a single African Economic Community would lead to a variety of issues - beginning with the fact that i.e. the EAC - as will be discussed later - is on a well-advanced level of integration. Furthermore, the question of the legal status of the post-merged RECs remains. In this regard, the COMESA Treaty for instance provides that the Assembly of the AU is allowed to terminate the operation of the COMESA. ${ }^{600}$

Apart from cooperation with subregional communities, the Treaty of the AEC foresees the establishment of six organs - inter alia the establishment of the above-discussed Pan-African Parliament and the Economic and Social Commission (ECOSOC) ${ }^{601}$ ECOSOC is inter alia responsible for the coordination, harmonization and supervision of the economic, social, cultural and technical services of the Secretariat of the AEC, the Technical Committees and other bodies. Furthermore, the ECOSOC is responsible for ensuring the commitment of economic ministers to safeguard economic development, planning as well as the integration of each Member State. ${ }^{602}$

Due to the slow progress with regard to the establishment of the AEC, in 2012 during the $18^{\text {th }}$ Ordinary Session of the Assembly held in Addis Ababa, Heads of State and Government adopted a decision aiming to establish a Continental Free Trade Area in 2017. The Assembly further adopted an Action Plan on Boosting Intra-Africa Trade, which provides for seven priority action clusters, namely: trade policy, productive capacity, trade facilitation, trade related infrastructure, trade information, trade finance as well as factor market integration. In 2018 African Heads of State and Government held an Extraordinary Summit in the African Continental Free Trade Area in Kigali, Rwanda. Within the session, 44 AU Member States signed the Agreement on the African Continental Free Trade Area. Art. 3(1)(a) of the Agreement establishing the African Continental Free Trade Area (AfCTA) outlines the objective of the AfCTA to be the creation of a single market for goods, services, facilitated movement of persons in order to achieve deeper economic integration within the whole African continent. Besides that according to Art. 3(1)(b) the AfCTA aims to achieve the creation of a liberalized market for goods and services. In order to achieve the objectives mentioned in Art. 3, Art. 4 inter alia stipulates that the parties shall eliminate tariffs and non-tariff barriers, to liberalize trade in services and to cooperate in trade-related areas. Besides that Art 5 stipulating the principles

\footnotetext{
599 Oppong (2011a), 9.

600 See: Art. 192(1) of the 1994 Treaty Establishing the Common Market of Eastern and Southern Africa (COMESA).

601 Senghor (1993), 187.

602 Ibid.
} 
of the AfCTA stipulates that the latter shall be governed by RECs that function as building bloc for the AfCTA and the Most-Favoured-Nation Treatment as well as variable geometry.

Additionally to the Agreement establishing the AfCTA, the Protocol to the Treaty Establishing the African Economic Community relating to the Free Movement of Persons, Right to Residence and Right to Establishment was signed. ${ }^{603}$ The Agreement itself however will not create a continental trade area itself - it will rather form the umbrella for a Protocol on Trade in Goods, Trade in Services as well on Intellectual Property Rights. ${ }^{604}$

If all instruments are ratified, the African Continental Free Trade Area will exist formally. Similar to the AEC, the African Continental Free Trade Area will use the RECs as building blocks. ${ }^{605}$

\subsection{Conclusion on the Economic wing of the African Union (AU)}

The African Union, and before it the OAU, installed several organs to ensure economic integration on the African continent. The AEC provides for numerous steps for the final implementation of an African Customs Union, however such establishment through subregional economic communities remains an ambitious goal. As will become outlined in further chapters of this dissertation, the status of development of subregional institutions differs enormously. Furthermore, each country or at least each region provides for a different law system, which in turn delays regional integration. However, above all, lack of consistent political will slows down integration goals. Furthermore, due to experiences related to colonialism, African leaders remain suspicious of the opening of their markets.

However, especially, the NEPAD with its APRM not only focuses on economic integration but also aim at ensuring the adherence to the rule of law. However, the APRM does not provide for a legally binding instrument to the AU Member States, which limits the effectiveness of human rights protection and therefore, the protection of the rule of law. Moreover, the achievements with regard to economic integration encourage the protection of human rights, which are mentioned in the African Charter and the African Charter on the Rights and Welfare of the Child. For instance, better education and health systems also promote the more effective protection of the right to education and the right to health within the African continent.

603 Tralac Trade Law Centre 'African Continental Free Trade Area (AfCFTA) Legal Texts and Policy Documents', available at: https://www.tralac.org/resources/by-region/cfta.html, (last visited: 08.10.2018).

604 G. Erasmus, How will the AfCFTA be established an its Legal Instruments be implemented? available at: https://www.tralac.org/discussions/article/12869-how-will-the-afcfta-be-establishedand-its-legal-instruments-be-implemented.html, (last visited: 08.10.2018).

605 Ibid. 


\subsection{Final conclusion to the African Union (AU)}

The African continent for a long time struggled with the project to establish a sustainable regional human rights mechanism, but since the beginning of the new millennium, it achieved many steps in order to provide for a greater human rights protection. This happened not only through institutions, such as the African Court of Human and Peoples' Rights but also through treaties recognizing the protection of human rights and the rule of law. Some of the treaties such as the Protocol on Women constitute a unique instrument worldwide on the regional level.

One reason for the difficulties with regard to the establishment of a fully working human rights system within the AU is the low standard of development. Furthermore, many financial issues influenced the development of a human rights system. Finally, suspicion concerning Western models, such as the European Union was also an issue, after all, the orientation on Western standards has been categorized as 'a form of foreign intervention.' ${ }^{\text {'06 }}$

The OAU did not - in such manner- had human rights protection as objectiveinstead military rule, armed conflicts and authoritarianism have been the order of the day and the target to end colonialism within the continent.

Despite the progress that took place during the last decades, the human rights system - in comparison to the Inter-American and the European Union - remains the weakest regional human rights systems worldwide. ${ }^{607}$ It was of global interested, to establish a strong human rights system within Africa and thus the UN contributed a lot with the aim of creating a human rights system in Africa by using its moral authority and the appointing of many conferences. ${ }^{608}$

In conclusion, the African Union provides for many approaches to promote the rule of law and thus the protection of human rights. However, most of the institutions remain pretty much ineffective. The level of the promotion of the rule of law until today primary depends on the political will of Heads of State and Government of whom some of them are dictators. For instance, there are pushes in order to extend the competences of the Pan-African Parliament. It remains to be seen if the Heads of State and Government will comply with the efforts in order to give the PAP a more effective mandate.

However, it is remarkable, that the African Court on Human and Peoples' Rights - together with the African Commission forwarding some requests to the Court - perform, more or less, well. This quite young Court became increasingly more active during the last years. Further, the Commission keeps issuing more and more communications. Its efficiency remains, similarly to the Court, limited - due to its part-time structure.

\footnotetext{
606 Polymenopoulou (2012), 767.

607 Ibid.

608 Viljoen (2007), 87.
} 
For the future, it remains to be seen if the merging of both courts, the African Court of Human and Peoples' Rights and the African Court of Justice will stifle the achievements of the African Court. Taking into consideration the planned establishment of the Criminal Chamber, the new Court may experience a negative financial impact on its Human Rights Section, since the prosecution in international criminal law is very costly. The new criminal chamber itself might not have a great impact on the protection of the rule of law in Africa, due to the decisions of the Heads of State and Governments concerning the impunity of serving Heads of State and government and senior officials.

In addition, the African Union provides for institutions which promote deeper economic integration - NEPAD and AEC. Besides their preliminary economic-related aims, especially the NEPAD also focuses on effective human rights protection through APRM. Its effectiveness still remains quite limited due to its non-binding character. The economic institutions indirectly may influence the development of human rights standards and the adherence of them, since economic development usually improves human rights standards as well as the rule of law. 


\section{Chapter 3: \\ The protection of human rights on subregional level - an introduction}

After the adoption of the Charter of the Organization of African Unity (OAU), which marks the beginning of the process of regional integration in Africa, several subregional economic communities have been formed in the same time. The dissertation will focus on the regional economic communities (RECs) of sub-Sahara Africa, including the East African Community, (EAC), the Economic Community of West African States (ECOWAS), the Southern African Development Community (SADC), as well as the Common Market of Eastern and Southern Africa (COMESA).

The foundation of subregional economic communities in Africa began in the 1960s, when the United Nations Economic Commission for Africa recommended that African countries should establish subregional systems with the goal to establish the African Economic Community (AEC) ${ }^{609}$

The decision of the OAU to divide the African continent into five sub-regions in 1996, supported the process of subregional economic integration. The ratification of the Abuja Treaty, leading to the foundation of the African Economic Community in 1994, gave another meaningful input to the foundation of subregional entities.

$\overline{609}$ Murungi \& Gallinetti (2010), 119. 
The Treaty of the AEC - as the ultimate goal - sets for the establishment of a Common Market as well as a Pan-African Economic and Monetary Union. A first step towards the achievement of this goal is the strengthening of the already existing subregional economic communities. ${ }^{610}$

Unlike the provisions of Art. 52 of the United Nations Charter require, the Treaties of the several RECs - at time of their establishment - did not provide for any mechanisms regarding the protection and promotion of rule of law - especially human rights. However, most RECs little by little adopted the protection of human rights and therewith the promotion of the rule of law in their mandate. Not only human rights but also other principles such as good governance and democracy gained of importance. ${ }^{611}$ Incorporating the protection of human rights, RECs generally refer to the African Charter on Human and Peoples' Rights to be the normative standard. ${ }^{612}$ One reason for the implementation of the Charter is the fact that the Charter sets out several obligations regarding intrastate relations within the continent. Thus, African States need to respect human rights obligations also with regard to subregional economic communities. ${ }^{613}$

Besides that, subregional economic communities realized that giving consideration to human rights regularly facilitates an appropriate climate for further investments. Thus, the appropriate reflection of human rights gives more security to investors and trading parties, which may lead to faster development within the respective community. Accordingly, the attention to human rights can be seen to generally lead to economic growth. ${ }^{614}$

In the future, the RECs will become absorbed into the AEC in order to create an African Economic Community. In order to achieve this goal, RECs and the AU established a link in order to strengthen the cooperation with the AU. Moreover, many treaties provide for a regulation that allows cooperation with other RECs. The probably most significant cooperation agreement until now was the COMESA-EAC-SADC Tripartite Summit of Heads of State and Governments in 2008 with the topic: 'Deepening COMESA-EAC-SADC' ${ }^{615}$

At the subregional level, the Southern African Development Community (SADC), the East African Community (EAC) as well the Economic Community of West African States (ECOWAS) have been especially actively involved in the promotion and protection of human rights in the African continent. ${ }^{616}$

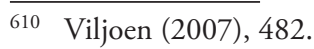

611 Ibid, 487.

612 A. Possi, 'East African Court of Justice: Towards Effective Protection of Human Rights in the East African Community', Max Planck Yearbook of United Nations Law (2013), 173, 178.

613 Viljoen (2007), 499.

614 Ibid.

615 J. Oloka-Onyango \& D. Udagama, Human Rights as the primary objective of international trade, investment and finance policy and practice (1999), para 47.

616 Oppong (2011b), 67.
} 
Originally, RECs were established in order to improve economic integration with the aim to improve the living standards of the respective citizens. Until today, the East African Community is the only REC, which is recognized by the AEC to form a building block. With the establishment of RECs, African countries, where mostly provide for just a small domestic market, may deepen their integration goals in order to improve their competitiveness and in order to become more attractive to external investors. ${ }^{617}$

Besides the Charter of the United Nations, also the WTO, specifically the General Agreement on Tariffs and Trade (GATT), provides for means of regional integration.

The GATT was implemented in 1947, after World War II, since many politicians saw the restrictive trade as one of the main factors contributing to the War breaking out. ${ }^{618}$

The main provisions regarding the establishment of RECs are outlined in Art. XXIV of GATT.

During the last decades, many Regional Trade Agreements (RTAs) - also with respect to Africa - emerged. Thus, RTAs cannot be seen anymore as an exception to the WTO rules. This assessment is supported by the fact that almost every WTO Member State is also a member of at least one RTA. ${ }^{619}$

In general, RTAs contradict one of the core principles of the regulation of international trade - namely the principle of non-discrimination. This principle inter alia is reflected in the Most Favored Nations (MFN) requirement, Art. I(1) GATT. This rule requires 'each contracting party to accord or to extend the same tariff treatment to the trade of all other contracting parties in respect of similar products'.

The negotiators of the GATT did fear that the establishment of RTAs would lead to more protectionism, in turn contradicting the principles of the WTO. Thus, the negotiators implemented a number of requirements for the establishment of RTAs in Art. XXIV GATT. ${ }^{620}$

The GATT mentions different forms of RTAs depending on the extent of economic integration of the respective country - Customs Unions, Free Trade Areas, and Interim Agreements. Besides that, RTAs can take the form of either a common market or economic union - depending on their level of integration. ${ }^{621}$

Not only Art. XXIV GATT, but also Art. V of the General Agreement on Trade in Services (GATS), as well as the Enabling Clause, set out some provisions for trade agreements to be in conformity with WTO law for RTAs. The provisions of the GATT also provide for an establishment of a Preferential Trade Areas (PTAs) which are not bound by the MFN Principle. ${ }^{622}$

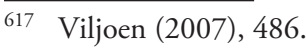

618 Z. Hafez, 'Weak Discipline: GATT Art. XXIV and the Emerging WTO Jurisprudence on RTAs', 79 ND L Rev (2003), 881.

619 Ibid.

620 Boisson de Chazournes (2017), 114.

621 Hafez (2003), 884 et seq.

622 M. Forere, The Relationship of WTO Law and Regional Trade Agreements in Dispute Settlement, Global Trade Law Series (2015), 95. 
Art. XXIV GATT refers to inter alia Customs Union (CU), which generally eliminates trade barriers in goods or between its Member States while adopting a common external tariff that is applied by all members of the respective $\mathrm{CU}$ in order to trade with countries outside of the union. ${ }^{623}$

Similarly to a CU, a Free Trade Area eliminates barriers in order to trade between or among their members. However, members retain all of their pre-existing tariffs and trade barriers in their respective trade relations with their countries. Art. XXIV: 8 provides the following definition for an FTA:

[A] free-trade area shall be understood to mean a group of two or more customs territories in which the duties and other restrictive regulations of commerce (except, where necessary, those permitted under Arts. XI, XII, XIII, $\mathrm{XIV}$, and XX) are eliminated on substantially all the trade between the constituent territories in products originating in such territories.

When the GATT was replaced by the WTO, participating parties of the Uruguay Round added an understanding of the interpretation of Art. XXIV for further clarification. The understanding called for a stricter assessment of the provisions of Art. XXIV and furthermore gives clarifications regarding some provisions. ${ }^{624}$

Among developing countries, RTAs can be formed under the enabling clause, also called the 'Decision on Differential and More Favorable Treatment, Reciprocity and Fuller Participation of Developing Countries'. Under this clause, developing countries are allowed to conclude RTAs only covering a small share of the tariff. ${ }^{625}$ For instance, both, the Common Market of Eastern and Southern Afri$\mathrm{ca}(\mathrm{COMESA})$ and the East African Community (EAC) have been formed under the enabling clause. In contrast, the Southern African Development Community (SADC) and the Southern African Customs Union (SACU) have been formed under the provisions of Art. XXIV GATT. The difference between both concepts is that Art. XXIV GATT requires 'substantial liberalization of all trade.' 626

In general, RTAs, at the time of their initial establishment, aim to ensure peace, security as well as regional integration. ${ }^{627}$ As the RTAs develop, it can be observed that some also addressed human rights.

623 Hafez (2003) 885.

624 C. Ng'ong'ola, 'The Reconstitution of the Southern African Development Community: Some International Trade Law Perspectives', 117 South African Law Journal (2000), 256, 258 et seq.

625 R. Acharya, 'Regional trade agreements: recent developments' in R. Acharya (ed), Regional Trade Agreements and the Multilateral Trading Systems (2016), 2.

626 Dirar (2010), 222.

627 C. B. Picker, 'Regional Trade Agreements v. The WTO: A Proposal for Reform of Art. XXIV to Counter this Institutional Threat', 26 U Pa J Int'l Econ L (2006), 274. 


\section{Chapter 4: \\ The Economic Community of West Africa (ECOWAS)}

\subsection{Introduction}

The Economic Community of West African States (ECOWAS) was launched after the entry into force of the ECOWAS Treaty in $1975 .{ }^{628}$ Fifteen States, namely Benin, Gambia, Ghana, Guinea, Ivory Coast, Liberia, Mali, Mauritania, Niger, Nigeria, Senegal, Sierra Leone, Togo and Upper Volta, signed the Treaty. ${ }^{629}$ A couple of months later, also Cape Verde joined the trade agreement. ${ }^{630}$

In 1993, almost 20 years later, a Treaty with many amendments - particularly with regard to the Community's powers - has been adopted. ${ }^{631}$ The new Treaty aims to promote a much broader and deeper integration within West Africa.

\footnotetext{
628 Viljoen (2007), 189.

${ }^{629}$ S. T. Ebobrah, 'A critical analysis of the human rights mandate of the ECOWAS Community Court of Justice', 54 J Afr L (2008), 1, 6.

${ }^{630}$ K. O. Kufour, 'Securing Compliance with the Judgments of the ECOWAS Court of Justice', 631 8 Afr J Int'l \& Comp L (1996), 1.

Ibid.
} 


\subsection{Historical background on the establishment of Economic Community of West Africa (ECOWAS)}

The process of the establishment of ECOWAS has its beginnings in the $19^{\text {th }}$ century. It was first brought up in 1867 when the Africanus Beale Hortin ${ }^{632}$ proclaimed the message of self-government of the whole West Africa. ${ }^{63}$ Soon, other voices that were pushing towards regional integration in West Africa emerged and were all preaching their different views of regional integration within West Africa. ${ }^{634}$

\subsubsection{First steps until the establishment of the Economic Community of West Africa (ECOWAS)}

The early nationalists within West Africa proposed inter alia the establishment of a single West African State with a capital based in Liberia as well as the implementation of a University of West Africa, which was supposed to be located in Sierra Leone. ${ }^{635}$ The goal of a united West Africa was not attainable at this point of time but it was picked up again in the 1960s by two West African nationalists, Kwame Nkrumah and Nnamdi Azikiwe with the aim to promote development within the region and proposed the idea of the creation of a West African Economic Union and Common Market. ${ }^{636}$

632 Africanus Horton, who was born in 1835 in Gloucester, Sierra Leone, was also known as James Beale. He was a Creole African nationalist writer and esteemed medical surgeon in the British Army from Freetown, Sierra Leone. He was a surgeon scientist, soldier and a political thinker, who was working towards the African independence; see: G. Martin, African Political Thought (2012).

633 O. A. Ovrawah, 'Harmonisation of Laws within the Economic Community of West African States (ECOWAS)', 6 Afr J Int'l \& Comp L (1994), 76.

634 The other persons who thought of this idea have been inter alia Edward Wilmot Blyden, who was a Liberian of West Indies decent, and JE Casely Hayford from Ghana, who was described as the ideological heir of Blyden, see: E. S. Nwauche, 'Enforcing ECOWAS Law in West African National Courts', 55 J Afr L (2011), 181, 183.

635 Horton and Blyden proposed the idea for the economic and political integration of West Africa based on notions of cultural solidarity and necessity. According to Eric Edi, Horton preached the idea that West Africa would benefit from unification and self-government, while Blyden is reputed to have travelled across the British colonies in West Africa preaching a united West Africa and propagating the idea that the salvation of the continent would come from the birth of a West African State see: Nwauche (2011), 183.

636 S. Godwin-A Hart, 'Integrating Trade and Human Rights in West Africa: An Analysis of the Ecowas Experience Discussion Pieces', 32 Windsor Rev Legal \& Soc Issues (2012), 57, 60. 
France, in the meantime already implemented a francophone organization, ${ }^{637}$ which connected former French West African colonies more closely to France while creating an economic and monetary organization. ${ }^{638}$

\subsubsection{The final negotiations towards the adoption of the ECOWAS Treaty}

Finally, in August 1964, ambassadors of Sierra Leone, Liberia, Guinea and Côte d'Ivoire met in Monrovia, Liberia to amplify the idea of the creation of a regional trade area within West Africa.

The outcome of the gathering was the preference of an implementation of a free trade area within West Africa. Also, the States that have been involved in that meeting felt that other States should be able to join the free trade area. During that meeting, an Interim Committee was created to discuss the issues related to the creation of a free trade zone and to issue its recommendations to the four countries that had been involved in the Congress. ${ }^{639}$

During the negotiations, the Nigerian Federal Commissioner for Economic Development and Reconstruction, Adebayo Adedji, stressed out the need of economic integration within West Africa and therefore stated:

We are here today to explode the myth that differences in language, culture and economic level necessarily render impossible the achievement of meaningful cooperation in West Africa. We have precedents to guide us. It is a fact of history that after the Second World War, bitter enemies such as Germany and France are working together under the umbrella of EEC. Luxembourg, a relatively small country, is also cooperating with economic giants like France and Germany. In the EEC there are as many as nine languages and these countries are no less heterogeneous culturally... Today, the EEC is the richest economic grouping in the world because its members have learned to share their technological and scientific know how which has accelerated their economic growth... If the EEC has taken so many years to develop the height that it has now reached, we in West Africa must be realistic. ${ }^{640}$

637 French West Africa was a federation of eight colonial territories in Africa: Mauritania, Senegal, French Sudan (now Mali), French Guinea, Ivory Coast Upper Volta (now Burkina Faso), Dahomey (now Benin and Niger. The federation existed from 1895 until 1960 and its capital was Dakar and deemed for the administration of the French colonial territories. see: J. Suret-Canale, French Colonialism in Tropical Africa, 1900-1945 (1971).

638 Viljoen (2007), 493.

639 J. E. Okolo, 'ECOWAS Regional Cooperation Regime', German Yearbook of International Law (1989), 111.

640 C. Hartmann, Governance Transfer by the Economic Community of West African States (ECOWAS) (2013), 8. 
The ECOWAS Treaty was finally signed on 28th May 1975, and after the ratification by seven States, it came into force in June 1975. ${ }^{641}$ The Treaty represented many years of efforts of many people of that region with the aim to achieve inter alia economic growth and cooperation. ${ }^{642}$

At the time of establishment of ECOWAS, the region was unstable, and the level of intra-regional trade was very low due to high trade barriers.

Moreover, the Francophone countries were still highly dependent on France. Furthermore, there was no consensus regarding economic goals between Ghana and Nigeria, the two big Anglophone countries within the region. ${ }^{643}$

The next decade for West Africa was marked by political conflicts throughout the region. In the early 1980s, Nigeria was affected by the worldwide slump of the oil prices and thus needed to focus more on domestic issues. As a consequence, Nigeria expelled hundreds of 'illegal' workers in 1983, ignoring the provisions of a more open immigration policy set out in the ECOWAS Treaty and its Protocols ${ }^{644}$. 645

In the meantime, statistics were showing that integration did not succeed as planned despite the 'enthusiasm at the organization's inception, its economic integrative schemes were not as successful as initially anticipated. ${ }^{.646}$

The crisis in Liberia of 1990 might be another trigger for the implementation of political objectives in the Treaty as amended. During the first period of existence of ECOWAS, military interventions in at least three ECOWAS Member States took place. Thus, many voices supported the 'transformation of ECOWAS into a political integrative process with a security component.' ${ }^{647}$

In particular, the Authority of Heads of States and Government set up a Standing Mediating Committee to solve the crisis. Regarding the designated ceasefire, a military force - the so-called ECOWAS Ceasefire Monitoring Group was established to monitor and control the situation in Liberia. ${ }^{648}$

\footnotetext{
641 Okolo (1989), 111.

642 Ibid.

643 Hartmann (2013), 8.

644 For instance, the Protocol A/P.1/5/79 Relating to Free Movement of Persons, Residence and Establishment.

645 K. J. Alter, L. R. Helfer \& J. R. McAllister, 'A New International Human Rights Court for West Africa: The Ecowas Community Court of Justice', 107 Am J Int'l L (2013), 737, 742 et seq.

646 F. Olonsakin \& E. K. Aning, 'Humanitarian Intervention and Human Rights: The Contradictions in ECOMOG', 3 Int J Hum Rt 1 (1999), 16, 17.

647 Alter et al (2013), 743.

648 Ebobrah (2008), 7.
} 


\subsection{Purposes and Objectives of the Treaty of the Economic Community of West Africa}

The 1975 Treaty of the Economic Community of the West African States (ECOWAS) aimed to eliminate the tariff as well as non-tariff barriers in order to reach trade liberalization in West Africa in two consecutive stages. ${ }^{649}$

The ultimate objective of ECOWAS, as manifested in the Preamble of the 1975 treaty, was '[...] to promote accelerated and sustained economic development of their States and the creation of homogeneous society, leading to the unity of the countries of West Africa by the elimination of all types of obstacles to the free movement of goods, capital and persons.' In order to achieve the final goal of integration, several stages of integration were proposed with an accompanying timetable.

During the first stage, to be completed in 1977, organizational issues were handled along the collection of information concerning customs duties. ${ }^{650}$ Afterwards, by 1985 , in relation to the second stage of integration, the Member States were to eliminate their import duties. ${ }^{651}$

In order to achieve these goals, the creation of a free trade area and the possible implementation of a customs union were set out in the Treaty. ${ }^{652}$ In addition, markets were to be opened in order to attract foreign investment and to ensure the development of that area. ${ }^{653}$

As the next step of integration, a common external tariff was to be established and installed by 1990.654

Art. 3 of the 1975 Treaty advises the member states to

make every effort to plan and direct their policies with a view to creating favorable conditions for the achievement of the aims of the Community; in particular, each Member State shall take all steps to secure the enactment of such legislation as is necessary to give effect to this Treaty.

Regarding the understanding of the wording best effort it is to mention, that five years later the Member States ratified only one out of five Protocols that were adopted by the Authority. 655

\footnotetext{
649 S. B. Ajulo, 'Law, Language and International Organisation in Africa: The Case of ECOWAS', 29 J Afr L (1985), 1.

650 Ibid.

651 Ibid.

652 See: Art. 5(2) of the 1975 Treaty Establishing the Economic Community of West Africa.

653 J. E. Okolo, 'Obstacles to Increased Intra-ECOWAS Trade Miscellany', Int'l J (1988), 17.

654 Alter et al (2013), 741.

655 Godwin-A Hart (2012), 65.
} 
Moreover, the negotiations with regard to a common external tariff were delayed due to several individual notions concerning tariffs of the Member States of the Communauté Èconomique de l'Afrique de l'Ouest (CEAU) as well as the Mano River Union. ${ }^{656}$

Owing to the internal conflicts in ECOWAS Member States, such as in Liberia, the ECOWAS Monitoring Group (ECOMOG) was established in 1990, to facilitate peacekeeping within the region. At this stage, not all of the ECOWAS Member States participated in force but the decisions were taken on behalf of the Authority of Heads of State and Governments. Finally, first, a ceasefire, followed by a ceasefire observation force between the warring parties was established. The force soon numbered about 5.000 members. Thus, in 1991 the Yamoussoukrou agreement was reached, which provided for a ceasefire and elections. The ECOWAS was finally able to impose sanctions against the National Patriotic Front of Liberia, when it became obvious that they did not comply with the agreement. Finally, the UN Special Representatives managed to persuade the parties to sign the Cotonou Agreement in 1993. ECOWAS now was responsible for the implementation of the ceasefire and elections in $1994 .^{657}$

The above-explained development is of great importance with regard to human rights issues for the following reasons:

First, the establishment of the cease-fire marks 'a decisive shift away from economic goals to the promotion of human rights. ${ }^{658}$ The intervention aimed to protect human lives and secure the restoration of democracy within the area. Furthermore, the ECOMOG is the first peacekeeping alternative for the African continent, meaning that the African continent can now endeavor to solve their upcoming issues without an outside help. ${ }^{659}$

656 The Mano River Union is an international association that became established between Liberia and Sierra Leone on 3 October 1971 due to the Mano River Declaration. The so-called Mano River starts in Guinea and then establishes the border of Liberia and Sierra Leone. Guinea joined the union on 25 October 1980. The objective of the union was to "accelerate the economic growth, social progress and cultural advancement of our two countries [...] by active collaboration and mutual assistance in matters of common interest in economic. social and technical scientific and administrative fields. However, due to several Civil Wars within the two founding countries, the objectives of the Union have not been received. see: Official Website of the African Development Bank Group, Mano River Union Capacity Building and Technical Assistance Institutional Strengthening, available at: https:/www.afdb.org/en/projects-and-operations/project-portfolio/p-z1-kf0-019/, (last visited: 6 September 2018).

657 T. Hartzenberg, 'Regional Integration in Africa', World Trade Organisation - Economic Research and Statistics Division (2011), 1, 14, available at: https://www.wto.org/english/res_e/ reser_e/ersd201114_e.pdf, (last visited: 12 September 2018).

658 Viljoen (1999), 197.

659 Ibid. 
The revised Treaty of 1993 clarifies the objective to constitute a legal system within the territory of ECOWAS. In particular, Art. 88 of the Treaty points out that the community should receive an international legal personality. Furthermore, the community was expected to implement a 'community legal system' ${ }^{660}$

Art. 3 of the ECOWAS Treaty as amended stipulated that the

aims of the Community are to promote co-operation and integration, leading to the establishment of an economic union in West African in order to raise the living standards of its peoples, and to maintain and enhance economic stability, foster relations among Member States and contribute to the progress and development of the African Continent.

Moreover, the Treaty as amended implemented the adherence to human rights. As a result, the human right mandate became one of the provisions of the ECOWAS Treaty. Art. 4 furthermore emphasizes that 'economic integration objectives of the ECOWAS must be carried out in a way that encourages with the promotion and protection of human and peoples' rights in accordance with the provisions of the African Charter on Human and Peoples' Rights ${ }^{661}$.'662

The African Charter introduced four fundamental freedoms that are guaranteed within the Community, namely the free movement of persons, goods, services and capital. Moreover, it also guaranteed the right to residence and establishment. ${ }^{663}$ The latter rights were strengthened by Art. 59, which imposes the obligation on the ECOWAS Member States to ensure the 'right of entry, residence and establishment of citizens of the Community'. Moreover, Art. 59 declares that these rights should be accessible to any ECOWAS citizen.

In addition, the revised Treaty includes the 'promotion and consolidation of a democratic system of governance in each Member State as envisaged by the Declaration of Political Principles.' ${ }^{644}$ Within ECOWAS, the activities in relation to principles of democracy and democratization are governed by the Protocol on Democracy and Good Governance adopted in 2001.

\footnotetext{
660 Nwauche (2011), 184.

661 Ibid., 182.

662 Art. 3 and 4 of the 1993 Treaty Establishing the Economic Community of West Africa.

663 See: Art. 3(2) (d) (iii) of the 1993 Treaty Establishing the Economic Community of West Africa.

664 See: Art. 4(j) of the 1993 Treaty Establishing the Economic Community of West Africa.
} 
For instance, regarding the unlawful change of government in Guinea in 2009, ECOWAS immediately implemented sanctions that have been set out in Art. 45(2) ${ }^{665}$ of the Protocol. ${ }^{666}$ Moreover, the new ECOWAS Treaty advises to realize popular, as well as economic and social justice and accountability ${ }^{667}$

In addition, the guarantee of security within the ECOWAS was of importance due to several civil wars in the area. Thus, in order to make possible military interventions, the Mechanisme de prévention, de règlement des conflits, de maintien de la paix et de la securité was adopted. In the light of Art. 2 (7) of the UN Charter, this protocol appears to be an exception. Thus, ECOWAS may intervene in case of grave human rights violations and violent conflicts. ${ }^{668}$

\subsection{Organs of the Economic Community of West Africa (ECOWAS)}

Art. 6 of the 1993 ECOWAS Treaty provides for the establishment of several institutions within the ECOWAS framework; the Authority of Heads of State and Government, the Council of Ministers, the ECOWAS Commission, the ECOWAS Court of Justice, Specialized Agencies, the Technical Committees, the Community Parliament and the ECOWAS Bank for Investment and Development (EBID).

The Authority is the principal governing institution of the Community and is responsible for the control of the executive functions of the Community. The decisions of the Authority are binding for all other institutions. The chairmanship of the Authority rotates annually. ${ }^{669}$

The Council is the second authority within ECOWAS. The decisions of the Council are binding to all subordinate institutions unless the Authority determines differently. The Council is composed of two representatives from each Member State and is designated to review the condition of the Community as well as the progress in achieving its objectives. The Council is further competent to make pol-

665 Art. 45(2) of the 2001 Protocol states: The sanctions which shall be decided by the Authority may take the following forms in increasing order severity: (1) Refusal to support the candidates presented by the Member State concerned for elective posts in international organisations; (2) Refusal to organise ECOWAS meeting in the Member state concerned; (s) Suspension of the Member State concerned from all ECOWAS decision-making bodies. During the period of the suspension the Member State concerned shall be obliged to pay its dues for the period.

666 S. T. Ebobrah, 'Human rights developments in African sub-regional economic communities during 2009', 10 African Human Rights LJ (2010), 245.

667 See: Art. 4(h) of the 1993 Treaty Establishing the Economic Community of West Africa.

668 K. Bado, Der Gerichtshof der Westafrikanischen Wirtschaftsgemeinschaft (ECOWAS) als Verfassungsgericht (2016) 8.

669 J. P. Jr. Holden, 'Economic Community of West African States (ECOWAS): A Legal Perspective on Its Present Status and Prospects Africa - Part II: General Studies - Chapter Two 6a', Mod Legal Sys Cyclopedia, 6A.220.229. 
icy recommendations to the Authority and to give directions to its subordinate institutions. The Council meets semi-annual but extraordinary meetings may be held if necessary. ${ }^{670}$

Furthermore, in accordance with Art. 22 of the Revised Treaty provides for the establishment of several Technical Commissions in several fields such as food and agriculture, legal affairs, tourism and trade.

The ECOWAS Commissioner is the principal executive officer of the ECOWAS Commission and is responsible for the day-to-day administration tasks. The commissioner is appointed by the Authority for a four-year term. Two Deputy commissioners and a Financial Controller appointed by the Council also assist the Commission. ${ }^{671}$

In addition, the Parliament of the Community is envisaged to be the Assembly of the peoples of the Community and its structure consists of a political and an administrative wing. ${ }^{672}$

The Community Court of Justice was created pursuant to the provisions of Arts. 6 and 15 of the Revised Treaty of the Economic Community of West African States (ECOWAS). The Court is mandated to ensure the governance to ECOWAS Law. The ECOWAS Bank for Investment and Development (EBID) is the financial institution established by the 15 Member States of ECOWAS. The EBID is mandated to promote private sector activities and to fund the development of the public sector. ${ }^{673}$

The several Technical Committees are mandated to prepare projects of the Community and to submit those projects to the Council through the Commission. The Technical Committee may take up projects on its own initiative or on requests. ${ }^{674}$

\subsection{The Court of the Economic Community of West Africa (ECCJ)}

The former ECOWAS Treaty allowed for the establishment of a Community Court if the Authority would make use of its powers under Art. 11(2) of the Treaty. In 1991, the Protocol A/P.1/A1/1991 on the Community Court of Justice was adopted by the Authority. ${ }^{675}$

Arts. 6 and 15 of the ECOWAS Treaty as amended in 1993 finally make provision for the establishment of a Community Court. Under the provisions set out in the Protocol of the Court of ECOWAS, the Court became the 'principal legal organ

\footnotetext{
670 See: Art. 10 of the 1993 Treaty Establishing the Economic Community of West Africa.

671 See: Art. 17 of the 1993 Treaty Establishing the Economic Community of West Africa.

672 See: Art. 13 of the 1993 Treaty Establishing the Economic Community of West Africa.

673 See: Art. 21 of the 1993 Treaty Establishing the Economic Community of West Africa.

674 See: Art. 23 of the 1993 Treaty Establishing the Economic Community of West Africa.

675 E. Ojomo, 'Competing Competences in Adjudication: Reviewing the Relationship between the ECOWAS Court and National Courts', 7 Afr J Legal Stud (2014), 87, 96.
} 
of the Community'. ${ }^{676}$ Moreover, the ECOWAS Treaty of 1993 called the Court to be one of the institutions within the ECOWAS system. ${ }^{677}$ The Court's headquarter is situated in Abuja, Nigeria. ${ }^{678}$

\subsubsection{The composition of the Court of the Economic Community of West Africa (ECOWAS)}

Until the amendment of the Treaty of ECOWAS, it was the responsibility of the Heads of State and Government to determine the composition, statutes and competences of the Court. ${ }^{679}$

The revised ECOWAS Treaty stipulates that the Court shall be composed of seven full time-serving judges. ${ }^{600}$

The Authority of Heads of States and Government, which can choose from a list of names, usually determines the judges of the ECOWAS Court. The list is issued by the ECOWAS Member States. ${ }^{611}$ The judges shall be persons of high moral character. In general, their appointment is for a four-year term office. The appointed judges need to possess the judicial qualifications for the highest judicial offices in their respective countries. Besides that, the judges may be jurists of recognized competence in international law. No person that is younger than 40 years and older than 60 years shall be eligible to become a member of the Court. ${ }^{682}$

Additionally, the Protocol on the Court of Community requires that no two judges from the same Member State may be chosen. ${ }^{683}$

The appointed members of the Court shall then elect a President and a Vice President of the Court, to serve a three-year term. ${ }^{684}$

\subsubsection{Limited jurisdiction of the Court of the Economic Community of West Africa (ECOWAS)}

The jurisdiction and the functions of the Court are set out in Art. 76 of the amended Treaty. In accordance with the provisions, the Court may handle

676 M. N. Ankrah, Regionalism and Political Instability in West Africa: Developments, Challenges and Prospects (2013), 93.

677 See: Arts. 6 and 15 of the 1993 Treaty Establishing the Economic Community of West Africa

678 S. T. Ebobrah, 'Litigating Human Rights Before Sub-Regional Courts in Africa: Prospects and Challenges', 17 Afr J Int \& Comp L (2009), 79, 84 et seq.

679 Godwin-A Hart (2012), 86.

680 See: Art. 6 of the 1993 Treaty Establishing the Economic Community of West Africa.

681 See: Art. 3 (4) of the 1991 Protocol on the Community Court of Justice.

682 See: Art. 3 (1) and (7) of the 1991 Protocol on the Community Court of Justice.

683 See Art. 3 (2) of the 1991 Protocol on the Community Court of Justice.

684 See: Art. 3(2) of the 1991 Protocol on the Community Court of Justice. 
- 'Any dispute regarding the interpretation or the application of the provision of this Treaty shall be amicably settled through direct agreement without prejudice to the provisions of this Treaty and relevant Protocol;

- Failing this, either party or any other Member State or the Authority may refer the matter to the court of the Community whose decision shall be final and shall not be subject to appeal.'

Additionally, the Court is obliged to carry out its functions independently of the Member States. ${ }^{685}$

In accordance with Art. 9 (2) of the Court's Protocol, the Court is competent to deal with disputes referred to it, in accordance with the provisions of Art. 56 of the Treaty, by Member States of the Authority, when such disputes arise between the Member States or between one or more Member States and the institutions of the Community on the interpretation or application of the provisions of the Treaty.

Still, the jurisdiction of the Court was limited, since only a Member State against another Member State, as well as the Community institutions, or a Member State that acts on behalf of an individual citizen of an ECOWAS State were allowed to bring a claim to the Court. ${ }^{686}$

In accordance with Art. 15(4) of the ECOWAS Treaty, the judgments of the Court are binding on the Member States, the institutions of the Community as well as corporate bodies and individuals.

In order to enforce its rulings, the Court is enabled to make use of the following sanctions set stipulated in Art. 77 of the new Treaty:

- Suspension of new Community loans or assistance

- Suspension of disbursement on on-going Community projects or assistance programs;

- Exclusion from presenting candidates for statutory and professional posts;

- Suspension of voting rights; and

- Suspension from participating in the activities of the Community.

The amended Treaty did not include the access to the Court by individuals within the Community but did foresee the settlement of disputes brought by either the Authority or its Member States. ${ }^{687}$

685 See: Art. 10 of the 1993 Treaty Establishing the Economic Community of West Africa.

686 C. Nwankwo, Legitimation of the Economic Community of West African States (ECOWAS):

A Normative and Institutional Inquiry (2014), 85.

687 A. Del Vecchio, International Courts and Tribunals - between globalisation and localims (2013), 90 . 
In 2001, under the implementation of the Protocol on Democracy and Good Governance, the following provision was introduced to the 1991 Protocol: '[...] to give the Court the power to hear, inter alia, cases relating to violations of human rights, after all attempts to resolve the matter at the national level have failed.' ${ }^{688}$ Thus, read in line with Art. 9 of the Protocol relating to the Court, the new provision allows to submit human rights-related cases to the Court. ${ }^{69}$

Due to the introduction of the new provision, the first case involving an individual complaint - Afolabi Olajide v. Federal Republic of Nigeria ${ }^{690}$ - was forwarded to the Court in 2003. ${ }^{691}$

The applicant, $M r$. Afolabi, who was a businessman, finalized agreements with his customers in the Republic of Benin wherein the parties agreed that Mr. Afolabi should purchase goods and deliver them on the date agreed upon. When he travelled to the border of Nigeria and Benin, he found the border being closed by the Ministry of Foreign Affairs until the Republic of Benin had fulfilled the condition precedent for the opening of the border. As such, Mr. Afolabi was unable to enter Benin even though he referred to his contractual obligations. Thus, he suffered financial losses and alleged a possible violation of his right of free movement, which is guaranteed by Art. 12 of the African Charter on Human Rights. Therefore, he submitted a case to the Court in order to enforce his rights under Art. 9 of the Protocol on the ECCJ and Art. 76 of the ECOWAS Treaty.

On 27 April 2004, the Court issued its decision on this case. The Court argued in the ruling that the institution is not competent to discuss the case that was implemented by the plaintiff.

The ECOWAS Court, however, found that the complaint 'raised[ed] a serious claim touching on free movement and free movement of goods and rights and his rights to challenge an infringement upon his person. ${ }^{3} 92$

As per the opinion of the Court, the Plaintiff had no locus standi to maintain this claim before the ECCJ. The Court furthermore stated that due to Art. 9(3) of the Protocol on the ECCJ, the Court can hear disputes being instituted by a Member State on behalf of the citizens but not by the citizen himself. ${ }^{63}$

Moreover, the Court pointed out that Art. 9 (3) of the Protocol is not in pari material with Art. 34 of the International Court of Justice Statute, which contains a clear intendment excluding persons not being mentioned therein. Therefore, the Court is not able to entertain the claim of Afolabi Olajide due to a lack of jurisdiction.

\footnotetext{
688 Ojomo (2014), 97.

689 Ibid.

690 Olajude Afolabi v. Federal Republic of Nigeria, ECW/CCJ/JUD/01/04, Judgment of 27 April 2004.

691 J. T. Gathii, African Regional Trade Agreements as Legal Regimes (2011), 281.

692 See: Olajude Afolabi v. Federal Republic of Nigeria, para 55.

693 Alter et al (2013), 749.
} 


\subsubsection{Extension of the jurisdiction of the Court of the Economic Community of West Africa}

In 2005, the jurisdiction of the ECOWAS Court was extended and thus the Court became more and more active. ${ }^{64}$ The limited jurisdiction of the Court indicated the issues of effectiveness of the Treaty of 1975 since most international trading efforts involve also the private sector. ${ }^{695}$

Thus, owing to the dismissal of the claim of Afolabi, the judges of the ECOWAS Court, as well as NGOs and Community officials, launched a campaign to extend the jurisdiction of the ECOWAS Court. While publishing the ruling of the Afolabi suit, the judges at the same time published another statement which urges governments 'to expand the Court's jurisdiction, relying on a clause in the 1991 Protocol that invites such proposals. ${ }^{696}$

After some meetings between the involved NGOs, officials and judges, the ECOWAS Executive Secretary became a key player in this process. Most officials of the Secretary were frustrated by the financial issues relating to the Court and further supported the idea of a more active Court. Due to the support and commitment of the ECOWAS Secretary, the governments of ECOWAS did agree upon the Amendment of the Protocol. There was no opposition within ECOWAS governments regarding the introduction of a jurisdiction of human rights. However, the campaign did not have any impact on the unsatisfactory ruling of the Afolabi case. ${ }^{697}$

Hence, in January 2004, the Protocol of the Court was amended by a Supplementary Protocol, which expanded the mandate on the jurisdiction of the ECOWAS Court. ${ }^{698}$ The jurisdiction of the Court expanded through the implementation of the Supplementary Protocol. Art. 9 of the Protocol of 1991 was abolished and was replaced with new Arts. 9 and 10 which determine: '[a]ccess to the Court is open to the following $[\ldots]$ individuals and corporate bodies in proceedings for the determination of an act or inaction of a Community official which violates the rights of the individuals or corporate bodies, individuals on application for relief for violation of their human rights. ${ }^{699}$ Consequently, private litigants enjoy direct access to the Court. ${ }^{700}$

\footnotetext{
694 Godwin-A Hart (2012), 86.

695 Ibid., 67.

696 Alter et al (2013), 750.

697 Ibid.

698 Godwin-A Hart (2012), 86.

699 See: Supplementary Protocol as amended in 2005 (Protocol A/P1/91 of 06.07.1991 amended by Protocol A/SPI/01/05 of 19.01.2005).

700 K. J. Alter, J. R. Gathii \& J. R. McAllister, 'Backlash against international courts in West, East and Southern Africa: causes and consequences', 27 EJIL 2 (2016), 293, 296.
} 


\section{a) ECOWAS Court case law relating to the jurisdiction on human rights}

Since the extension of the jurisdiction of the Court, many cases carrying a significant meaning for the West African area, were submitted before the Court. The Court altogether became much more active after the extension of its jurisdiction.

aa) SERAP Scholar case v. Federal Republic of Nigeria

In order to understand the significance of the following case $\mathrm{s}^{701}$, it needs to be highlighted that the African Charter on Human and Peoples' Rights is generally enforceable in the courts of Nigeria. Art. 17 of the African Charter provides for the right to education. In contrast, the Nigerian constitution provides that the right to education is merely a directive principle of State policy. ${ }^{702}$ The Supreme Court of Nigeria stated in the case of General Sani Abacha v. Chief Gani Fawehinmi ${ }^{703}$ that the law of the African Charter is on a higher level than domestic law of Nigeria. However, in the case of inconsistency with the constitution of Nigeria it is void and null. ${ }^{704}$

The ECOWAS Court declared in its judgment that the right on education forms a justiciable right. The Court argued that Nigeria ratified the African Charter and thus it cannot be counted to be a directive.

With regard to the question on locus standi the Community Court decided that in public interest any personal connection of the plaintiff with the case is sufficient. Prior to this, Nigerian Domestic Courts decided ${ }^{705}$ that private plaintiffs would need to prove a personal connection with the public issue in order to file a lawsuit. Due to the jurisdiction of the ECOWAS Court, the plaintiff only would need to argue that a public interest exists. Thus, the Court decided that socio-economic rights are generally justiciable within the Republic of Nigeria. ${ }^{706}$

The consequence of the SERAP decision, however, is uncertain. If Nigerian Courts were to finally recognize the decision of the ECOWAS Court, the Nigerian law would need to be changed significantly and decisions such as Adesanya and Okogie would become overruled. ${ }^{707}$

701 SERAP v. Federal Republic of Nigeria, Application No. ECW/CCJ/APP/08/08, Judgment of 27 October 2009.

702 Del Vecchio (2013), 90.

703 General Sani Abacha v. Chief Gani Fawehinmi, Supreme Court of Nigeria, S.C. 45/1997, Judgment of 28 April 2000.

704 E. S. Nwauche, 'The ECOWAS Community Court of Justice and the horizontal application of human rights', 13 African Human Rights Journal (2013), 30, 33.

705 See e.g.: Okogie v. Attorney General of Lagos State (1981) 2 NCLR 350 and Oronto Douglas v. Shell Petroleum Development Company Limited (1999) 2 NWLR (pt 591) 466.

706 Nwauche (2013), 33.

707 H. S. Adjolohoun, 'The ECOWAS Court as a Human Rights Promoter: Assessing Five Years' Impact of the Koraou Slavery Judgment Part A: Articles', 31 Neth Q Hum Rts (2013), 342, 344. 
bb) SERAP Environment v. Republic of Nigeria

The following case ${ }^{708}$ Serap Environment $v$. Republic of Nigeria was decided by the Court in December 2012 and was of ground-breaking significance for the West African area.

The plaintiffs, in this case the Socio-Economic Rights and Accountability Project (SERAP), complained about the damages that were caused by some oil companies in the Niger Delta. The plaintiff listed about seven oil companies that were held responsible, together with the Nigerian government, for the oil damage in the Niger Delta. ${ }^{709}$ SERAP illustrated in its claim that oil companies have created a poor standard of living caused by the pollution of food and water. Two oil spills in 2001 and 2008 lead to a contamination of creeks in Ogbobo as well as Ogoniland and of local rivers. The oil spills furthermore caused the eradication of fish, which constitutes a food basis of the local population. As a consequence, local poverty raised and the SERAP argued that the oil companies violated the right to an adequate standard of living being provided as a socio-economic right in the African Charter.

In its ruling, the Community Court ordered Nigeria to undertake the environmental restoration of the Niger Delta, preventing the destruction of local resources and held that Nigeria violated Arts. 1 and 24 of the African Charter, which provides for the right of peoples to a general satisfactory environment favourable to their development.

As per the Court's opinion, it is not sufficient to pass protective laws, but rather effective action needs to be taken:

The adoption of [...] legislation, no matter how advance it may be, or the creation of agencies inspired by the world's best models, [...] may still fall short of compliance with international obligations in matters of environmental protection if these measures just remain on paper and are not accompanied by additional and concrete measures aimed at preventing the occurrence of damage or ensuring accountability, with the effective reparation of the environmental damage suffered.

In addition, the Court declared the perpetrators of the environmental damage accountable. ${ }^{710}$ However, it also declared that the oil companies could not be held accountable by the Court, but only the Nigerian Government and its agency. The main reason for this decision was that under international law only States and individuals, but no companies can be held liable for human rights violations. ${ }^{711}$

\footnotetext{
708 SERAP v. Federal Republic of Nigeria, ECW/CCJ/APP/08/09, Judgment of 10 December 2010.

709 General Abacha \& ORS v. Chief Gani Fawehinmi, Supreme Court of Nigeria, SC.45/1997, Judgment of 28 April 2000.

710 ECOWAS Community Court of Justice Holds Nigerian Government Liable for Human Rights Violations by Oil Companies Human Rights Brief 7th March 2013, SERAP v. Federal Republic of Nigeria, ECW/CCJ/JUD/18/12, Judgement of 14 December 2012, pp. 23.

711 Nwauche (2011), 187.
} 
Furthermore, the Court held that the government has to ensure the quickest possible elimination of the damages being caused by the oil spills. ${ }^{712}$

Thus, the Court ordered to protect the rights of the citizens to an adequate environment. ${ }^{713}$

cc) Peter David v. Ambassador Ralph Uwechue

In the following case ${ }^{714}$ decided by the ECOWAS Court, no State party but instead two individuals are involved.

The plaintiff is a Nigerian citizen working as an officer in the Nigerian police force. The defendant is also a Nigerian citizen and a former special representative of the Executive Secretary of ECOWAS.

The plaintiff claimed that his right to property, his right to work under equitable and satisfactory conditions and his right to respect and freedom from discrimination being protected under Arts. 1, 14, 15 and 28 of the African Charter were violated by the defendant. The plaintiff reasoned the violation with the fact that the defendant - on behalf of ECOWAS - did not pay the outstanding salary (Estacode Allowances) which arose during his services as a security orderly. The plaintiff thus claimed for the payment of the outstanding US\$ 80,470.715

The plaintiff invoked the claim under the provisions of Art. 10(c) of the Supplementary Protocol ${ }^{716}$ and not under Art. 10(d), which is more commonly used. ${ }^{717}$

The Court adopted the case under Art. 88 of the Courts' Rules of Procedure ${ }^{718}$ and asked the involved parties to present their legal arguments with regard to its competence.

Finally, the rulings of the Court mainly considered the question of whether it could 'adjudicate on cases of human rights violations brought by an individual against another individual.' Moreover, the ECCJ discussed the question whether disputes between two individuals may qualify as 'disputes relating to the Commu-

712 E. O. Ekhator, 'Improving access to environmental justice under the African Charter on Human and Peoples' Rights: the roles of NGOs in Nigeria', 22 Afr J Int'l \& Comp L (2014), 63, 73.

713 ECOWAS Community Court of Justice holds Nigerian government liable for human rights violations; SERAP v. Federal Republic of Nigeria, ECW/CCJ/JUD/18/12, Judgement of 14 December 2012, p. 29.

714 Peter David v. Ambassador Raph Uwechue, ECW/CCJ/APP/04/09, Judgment of 11 June 2010.

715 Ibid., paras 3 et seq.

716 In accordance to Art. 10(c) of the Supplementary Protocol of 2005, 'individuals and corporate bodies in proceedings for the determination of an act or inaction of a Community official which violates the rights of the individuals or corporate bodies.'

717 ECOWAS Community Court of Justice holds Nigerian government liable for human rights violations; at: http://hrbrief.org/2013/03/ecowas-community-court-of-justice-holds-nigeriangovernment-liable-for-human-rights-violations-by-oil-companies/, (last visited: 10 April 2017).

718 Art. 88 of the Rules of Procedure state that 'Where it is clear that the Court has no jurisdiction to take cognizance of an action or where action is manifestly inadmissible, the Court may, by reasoned order, after hearing the parties and without taking further steps in the proceedings, give a decision.' 
nity and its officials' and if any damages that are in relation to an act of one of the Institutions of the Community or official can be awarded without the Community being a party hereto. ${ }^{719}$

The Court issued that a totally unrestricted reading of Art. 9(4) could lead to a situation where the Court would replace the domestic courts, and thus would be flooded with all kinds of cases. This handling would lead to the creation of a competition between the ECCJ and domestic courts in the ECOWAS area. ${ }^{720}$ The ECCJ emphasized in its decision that 'such a result and unrealistic task' was not designated by the drafters of the Treaty and the Protocols and it had 'never [been] conferred on any international regional body of a similar nature'. ${ }^{721}$

dd) Chief Ebrimah Manneh v. The Gambia

In the dispute Chief Ebrimah Manneh v. The Gambia, ${ }^{722}$ the plaintiff was a citizen of the Republic of The Gambia. He was arrested by two officials of the National Intelligence agency of The Gambia at the Daily Observer's premises in Banjul on 11 July 2006 without any warrant of arrest. The government of The Gambia has not disclosed the reasons for his arrest. The efforts by his friends, family, and lawyers to find his whereabouts proved futile. Since his arrest, the plaintiff was detained at various different places. However, the plaintiff has not been charged with the Commission of any criminal offense. In addition, the conditions under which the plaintiff was detained were also dehumanizing. Moreover, the defendant ignored the counsel's letter demanding the plaintiff's release.

The ECOWAS Court found that it has the mandate to decide on human rights issues. In this context, Art. 14 (g) of the Revised ECOWAS Treaty needs to be mentioned, which provides that human rights need to be recognized, protected and promoted in accordance with the African Charter on Human and Peoples' Rights. ${ }^{723}$

In the particular case, the plaintiff primarily referred to Art. 6 of the African Charter on Human Rights. Art. 6 states that no one shall have his right to liberty restricted or limited unless it is in accord with a law previously laid down. ${ }^{724}$

Furthermore, Art. 7(1) of the African Charter on Human and Peoples' Rights states that every national shall have the right to have his cause heard and this comprises among other things the right to be presumed innocent until proven guilty by a competent court or a tribunal, including the right to be defended by the counsel of

\footnotetext{
719 S. T. Ebobrah, 'Human rights developments in African sub-regional economic communities during 2011', 12 African Human Rights Journal (2012), 223, 234.

720 Ibid.

721 S. T. Ebobrah, 'Human rights developments in African sub-regional economic communities during 2010', 10 African Human Rights Journal (2011), 216, 235.

722 Chief Ebrimah Manneh v. The Republic of The Gambia (2008), ECW/CCJ/APP/04/07, Judgment ECW/CCJ/JUD/03/08, Judgment of 5 June 2008.

723 Ibid., para 12.

724 Ibid., para 13.
} 
one's choice and the right to be tried within a reasonable time by an impartial court or tribunal. The defendant has failed to put him before such a competent impartial court or tribunal for his guilt or innocence to be established. ${ }^{725}$

Thus, the ECCJ concluded that the defendant violated plaintiff's rights under Arts. 6 and 7(1) of the African Charter on Human and People's Rights. ${ }^{726}$

ee) Hissein Habré v. Republic of Senegal

In this case, ${ }^{727}$ Hissein Habré, the former President of Chad, was accused of having committed crimes against humanity, war crimes, and torture, after he seized power in Chad and of imposing himself as President in 1982. According to the opinions of a specialized Commission, more than 40,000 persons are presumed to be victims of summary executions, extrajudicial killings and torture.

Consequently, victims of the actions taken by the President lodged a criminal complaint in Senegal, where Habré fled to. However, the highest court of Senegal, Cour de Cassation, stated that the courts in Senegal do not have the jurisdiction to decide on crimes committed abroad. ${ }^{728}$

Thus, in 2005 a Belgian judge, after victims tried to invoke a case in Belgium courts which enjoy universal jurisdiction on international crimes committed abroad, issued an arrest warrant. Since Senegal did not comply with its obligations to arrest Habré, the African Union decided in July 2006 'to prosecute and ensure that Habré is tried, on behalf of Africa, by a competent Senegalese Court with guarantees for fair trial'. As a consequence, Senegal amended its domestic law in order to have jurisdiction over crimes on genocide, crimes against humanity and war crimes that were committed by individuals at their commission. ${ }^{729}$

In the meantime, Habré claimed before the ECOWAS Court that Senegal only amended its laws in order to have jurisdiction over him. Thus, he claimed, Senegal violated inter alia Art. 3.4 of the ICCPR, stating that 'no one shall be held guilty of any criminal offence on account of any act or omission which did not constitute a criminal offence, under national or international law, at the time when it was committed. ${ }^{730}$

In its ruling, issued in November 2010, he ECCJ found that a trial being executed under the current national law would violate the prohibition of retroactive criminal laws, stating that:

\footnotetext{
725 Ibid., para 21.

726 Ibid., para 41.

727 Hissein Habré v. Republic of Senegal, ECW/CCJ/APP/07/08, Judgment of 18 November 2010.

728 Ibid., paras 7.

729 Ibid., paras 13 et seq.

730 Ibid., para 19.
} 
[T] he mandate received by [Senegal] from the African Union provides it rather with a mission of conceiving and suggesting all proper modalities to prosecute and judge strictly within the scope of an ad hoc special procedure of an international character as is practiced in international law by all civilized nations. ${ }^{731}$

The ECCJ stated that a national court does not have jurisdiction over a case involving international crimes. Thus, the ECCJ proposed the installation of a special court in Senegal, one with international-court characteristics. The judges were to be appointed by the African Union. Senegal, however, withdrew the negotiations with the African Union on the creation of an ad hoc international tribunal. In addition, it refused to extradite Habré to Belgium for him to face trial there. ${ }^{732}$

Besides the claim before the ECOWAS Court, Belgium filed a claim at the International Court of Justice in February 2009 after it became obvious that Senegal refused to extradite Habré and delayed his trial. In 2011, after two extradition requests have been rejected, Senegal planned to send Habré back to Chad. However, owing to the resistance worldwide and the anticipation of the death penalty back home, he was allowed to remain in Senegal. In 2012, Senegal and the African Union signed a Treaty establishing the Extraordinary African Chambers in Senegal. The judges of the Chamber were appointed in 2015 and the trail began in 2016. ${ }^{733}$

ff) Hadijatou Mani Koraou v. The Republic of Niger

In 1996, when the applicant Ms. Hadijatou Mani Koraou was 12 years old she was sold to a 46-year-old tribal chief (El Hadj Souleymane Naroua) in Niger and was kept as a sexual slave. When she was finally released after nine years, she had four children by her violator, two of whom died. When she received the liberation certificate from slavery in August 2005, her violator did not allow her to leave the house and wanted her to be his wife.

After she escaped, in February 2006, she brought a complaint before the civil and customary tribunal, in order to officially receive the liberation from slavery recognized by Nigerian law. The Court accepted the claim and stated that the applicant and her violator have not been married properly. The violator however appealed before the Court of First Instance and won the case. Consequently, Hadijatou Mani Koraou took the case to the Judicial Chamber of the Supreme Court of Niamey. When finding that the applicant married her violator, the judge of the Supreme Court filed a criminal complaint against the applicant for bigamy and thus, she got arrested. She was condemned to prison for 6 months and was given a fine of 50,000 CFA Francs.

\footnotetext{
731 Ibid., para 60.

732 J. A. Hessbruegge, 'ECOWAS Court Judgment Habré v. Senegal Complicates Prosecution in the Name of Africa', 15 ASIL 4, available at: https://www.asil.org/insights/volume/15/issue/4/ ecowas-court-judgment-habr\%C3\%A9-v-senegal-complicates-prosecution-name-africa, (last visited: 6 September 2018). 
Consequently, she filed a claim before the ECOWAS Community Court $^{734}$ claiming that the actions of Niger would violate her fundamental rights. ${ }^{735}$

The Court first considered in its judgment if the exhaustion of domestic remedies in a general principle of international rights and concluded that even though the case was still pending before a Court of Niger, the rules of exhaustion are merely flexible. Furthermore, the ECOWAS Treaty did not provide for the necessity to exhaust domestic remedies. ${ }^{736}$

The Court also found that on account of the facts presented to the Court, the applicant has been held in slavery contrary to Art. 5 of the African Charter on $\mathrm{Hu}$ man and Peoples' Rights. The Court further found that national judges were obliged to bring a criminal prosecution and to punish this crime.

Due to physical and moral harm being suffered by the applicant, the Court finally justified the allocation of compensation of 10,000,000 CFA Francs. ${ }^{737}$

\section{b) Conclusion on the human rights related cases}

The above-described cases show that over time the Court became more and more active and courageous. In the last case Mani Koraou v. The Republic of Niger, the Court even adjudged that Niger was to pay the plaintiff compensation due to the suffered human rights violations, which is a great achievement for the plaintiff.

Moreover, in the SERAP Environment case, the Court explicitly recognized socio-economic rights, which although contained in the African Charter are not recognized in other international human rights instruments. Furthermore, it appears unique that an international Court initiated the establishment of a special international Court competent to hear international crimes.

In general, such development is most welcome. On the other hand, it may turn out to be an issue when the Court turns into one concerned solely with human rights issues. If it does so, the Court may - if it leaves general international law unnoted - face the withdrawal of the support from the governments. On the other side, if the Court were to be too hesitant in its development due to respect for the complete sovereignty of Member States, it would lose the approval of the people of the ECOWAS region. ${ }^{738}$

734 Hadijatou Mani v. Republic of Nigeria, Application No. ECW/CCJ/APP/08/08, Judgment of 27 October 2008.

735 Ibid., paras 8 et seq.

736 Ibid., paras 37 et seq.

737 Ibid., paras 92 et seq.

738 Ebobrah (2008), 25. 


\subsection{Enforcement of rulings issued by the ECOWAS Court}

The Court of Justice is the main institution to ensure the enforcement ${ }^{739}$ of the ECOWAS law. However, the Court in past struggled with the enforcement of its judgements in the respective Member State.

In this regard Art. 15 (4) of the ECOWAS Treaty as amended, states that judgments of the ECOWAS Court are binding on the Member States. Furthermore, Art. 22(3) of the Protocol relating to the Court asks Member State institutions to ensure the execution of all judgments while taking all measures being necessary. ${ }^{740}$

With regard to the relationship between the ECCJ and domestic courts, the ECCJ stated that it is either a court of appeal or a court of cassation regarding decisions of national courts. ${ }^{741}$

Besides that, the Protocol on the Community Court of 2005 states in Art. 10(f) that:

Where in any action before a court of a Member State, an issue arises as to the interpretation of a provision of the Treaty, or other Protocols or Regulations, the national court may on its own or at the request of the parties to the action refer the issue to the Court for interpretation.

This provision may lead to the conclusion that the Court does not have effective influence due to the following reasons:

Firstly, the provision concerns only the Community law - but not the African Charter on Human and Peoples' Rights, which forms the general legal basis for the jurisdiction of the ECCJ. In conformity with the provisions of the ECOWAS Protocol of Democracy and Governance, ECOWAS Member States have to respect the African Charter. ${ }^{742}$

However, the second - much more significant - argument is that the wording of Art. 10(f) does not have any binding character since it is only optional. This leads to the possibility that the domestic courts may only refer to the judgments if they choose to. It becomes, therefore, likely that the implementation of the ECOWAS Court jurisdiction depends on the 'spirit of cooperation' of the affected domestic courts. ${ }^{743}$

739 With regard to the two main regional integration institutions in the region - UEMOA and OHADA- see: A Zinzindohoué 'Autorité jurisdictionelle des cours internationales à l'égard des courts nationales: le cas de la Cour de justice de l'UEMOA' in AHJUCAF (ed), Internationalisation du Droit, (21-23 juin 2010), available at: http://v1.ahjucaf.org/IMG/pdf/ Internationalisation_du_droit.pdf, (last visited: 13 September 2018), 22-28. Peter David v. Ambassador Raph Uwechue, Suit No: ECW/CCJ/APP/04/09, Judgment of 11 June 2010, para 38.

741 Ebobrah (2008), 9.

742 Adjolohoun (2013), 359

743 Ibid. 
Furthermore, the vague wording of Art. 22(3) of the Protocol stating that Member States and institutions shall take all necessary measures to ensure the execution of the judgments leads to the fact that only 40 percent of the Court's judgments have been enforced within the institutions of the Member States. ${ }^{744}$

In general, most of the civil procedure rules of the Member States govern the enforcement of foreign judgments. For example, the Foreign Judgments Act of Nigeria allows the registration of a foreign judgment - and such decision - in conformity to the Nigerian law. The respective Court that registered the judgment enforces the decisions. ${ }^{745}$

Anyhow, it should be noted that the Protocol on ECOWAS Court of justice might not be directly enforceable in the involved Member State. The reason for this adversity might be 'traced to the different systems of treaty assimilation' within the region of the ECOWAS Treaty. ${ }^{746}$ Within the Anglophone Member States, the 'dualist system of treaty assimilation' applies, whereas in the Francophone and Lusophone States a monist system applies. These systems have different requirements regarding the recognition of international treaties. The ECOWAS Treaty binds monist States once it is ratified by the affected State. However, the Treaty always needs to be consistent with the constitution of the ratifying monist State. ${ }^{777}$ In these matters, because of their monist conception, it is clear in francophone countries that the ECOWAS Court is superior to national Courts. ${ }^{78}$

In contrast to the monist States, the dualist States still need to implement a domestic act in order to enforce the respective International Treaty. ${ }^{749}$

Thus, under the provisions of Art. 15(4) of the Treaty a domestic court should take into consideration the decisions of the ECOWAS Court. Whether domestic courts will accept this principle will be seen in the future. ${ }^{750}$

Therefore, it is not clear if in the English-speaking countries, the revised Treaty, as well as the judgments of the Community Court, are applicable and in case they are applicable if they are of superior power to the judgments of the domestic courts. ${ }^{751}$

Hence, Anglophone ECOWAS States may ignore the judgments of the ECOWAS Court. Since the decisions of the ECOWAS Court rely on Community law, they should be directly applicable in the Member States and should be superior to domestic courts' decisions. In order to solve this issue, the affected ECOWAS

\footnotetext{
744 Nwauche (2011), 194.

745 Adjolohoun (2013), 359 et seq.

746 J. O. Lokulo-Sodipe \& A. J. Osuntogun, 'The Quest for a Supranational Entity in West Africa: Can the Economic Community of West African States Attain the Status', 16 Potchefstroom Elec LJ (2013), 259 et seq.

747 Ekhator (2014), 77.

748 Nwauche (2011), 188.

749 Nwauche (2011), 188.

750 Adjolohoun (2013), 358.

751 Godwin-A Hart (2012), 194.
} 
Member States need to appoint a competent national authority, entitled to process the judgments of the ECOWAS Court. ${ }^{752}$ Such national authorities have not been determined as of yet. However, Art. 77(1) of the Revised Treaty provides that the Authority may impose sanctions against States which do not fulfill their obligations regarding ECOWAS. This provision however only becomes relevant if the respective dualist country had implemented the Treaty through a domestic act.

However, it appears possible that the human rights judgments of the ECCJ are not only enforceable in monist but also in dualist Member States. ${ }^{753}$

\subsubsection{ECOWAS Court case law relating to the enforcement}

During the last years, the ECOWAS Court decided a number of cases relating to the enforcement of its decisions by a domestic court in order to define its relationship with the domestic courts.

\section{a) Jerry Ugokwe v. Federal Republic of Nigeria}

In the case of Jerry Ugokwe v. Federal Republic of Nigeria and Others, ${ }^{754}$ the applicant claimed that the annulment of his election as a Member of the Nigerian National Parliament violated provisions of the ECOWAS law.

During the elections in Nigeria, Jerry Ugokwe was declared the winner of the election by the Independent National Electoral Commission. In connection thereto, a Nigerian Elections Tribunal reversed the decision of the Commission stating that Jerry Ugowke is not qualified to run for the seat. The Nigerian Federal Appeals Court upheld the same decision. The claimant not being satisfied with the decisions by the Nigerian courts, a claim before the ECOWAS Court was filed stating that the right of hearing would be violated. ${ }^{755}$

In this dispute the issue of the relationship between the national courts and the ECOWAS Court of Justice was of great importance. The ECOWAS Court stated in its findings, that the 'the distinctive feature' within the legal order of ECOWAS is that it finally 'sets forth a judicial monism of first and last resort in Community law. ${ }^{376}$

Consequently, the ECOWAS Court stated in its findings that it is not an appellate court with authority over national courts. Due to the constitution ${ }^{757}$ of the Federal Republic of Nigeria of 1999, the Court of Appeal is the final court to determine issues that are related to electoral offices into the legislative house. ${ }^{758}$

\footnotetext{
752 Viljoen (2007), 498.

753 Nwauche (2011), 195.

754 Jerry Ugokwe v. Federal Republic of Nigeria and Others, Application No. ECW/CCJ/ APP/06/14, Judgment of 30 November 2015.

755 Jerry Ugokwe v. Federal Republic of Nigeria and Others, Application No. ECW/CCJ/ $\mathrm{APP} / 06 / 14,2$.

756 Viljoen (2007), 509

757 See: Section 246(1)(b)(i), (3) of the 1999 Constitution of Nigeria.

758 Godwin-A Hart (2012), 87.
} 
This statement consequently means that even if the domestic courts need to implement the findings of the ECOWAS Court, the relationship between both, the national and regional court is not of vertical form. The Court thus concluded that it lacks the competence to decide on the claim forwarded by Mr. Ugowke. ${ }^{759}$

\section{b) Chude Mba v. The Republic of Ghana}

Most recently, the High Court of the Republic of Ghana had to decide on the enforcement of a decision issued by the ECOWAS Court. ${ }^{760}$ The applicant Chude $M b a$ strived for the enforcement of an US\$800,000 award in damages and 500,000 Nigerian naira ${ }^{761}$ awarded by the ECOWAS Court. The High Court of Ghana found that the key issue was the question 'whether this Court, or for that matter any other Courts in Ghana, can recognize and enforce the orders or judgment of the ECOWAS Community Court. ${ }^{762}$

Having in mind that Ghana is a 'dualist' country (the Parliament of the Republic of Ghana needs to give force to the international before the latter earns the force of law), ${ }^{763}$ neither the Protocol of the ECOWAS Court nor the Treaty establishing the ECOWAS has been enacted in Ghana.

Consequently, the Court rejected the claim of the applicant who argued the inaction of Parliament in enacting legislation to give effect to the Protocols of the ECOWAS Community Court should not bar this Court from recognizing and enforcing the orders of the Court. ${ }^{764}$

If the Act had given the power of law within Ghana, the High Court would have been bound by the decision of the ECOWAS Court in accordance with Art. 24 of the Protocol of the ECOWAS Court stating the following:

1. Judgments of the Court that have financial implications for nationals of Member States or Member States are binding.

2. Execution of any decision of the Court shall be in form of a writ of execution, which shall be submitted by the Registrar of the Court to the relevant Member State for execution according to the rules of civil procedure of that Member State.

\footnotetext{
759 Viljoen (2007), 509.

760 Chude Mba v. The Republic of Ghana, Suit No. ECW/CCJ/APP/01/13, Judgment of 6 November 2013.

761 Naira is the currency of the Republic of Nigeria.

762 C. Osisioma, 'Is the ECOWAS Court of Justice a Toothless Bulldog that Only Barks? Issues Arising from the Decision of the High Court of Mr. Chude Mba v The Republic of Ghana' (9 May 2016), available at: http://www.mondaq.com/Nigeria/x/489494/international+trade+ investment/Is+the+ECOWAS+Court+of+Justice+a+Toothless+Bulldog+that+Only+Barks+ Issues+Arising +from +the+Decision +of +the+High+Court+of+Accra $+\mathrm{in}+\mathrm{Mr}+\mathrm{Chude}+\mathrm{Mba}+$ $\mathrm{v}+$ The+Republic+of+Ghana, (last visited: 6 September 2018).

763 See: Art. 75(2) of the 1992 Constitution of the Republic of Ghana.

764 Osisioma (2016).
} 
3. Upon the verification by the appointed authority of the recipient Member State the writ is from the Court, the writ shall be enforced.

4. All Member States shall determine the competent national authority for the purpose of receiving and processing of execution and notify the Court accordingly.

5. The writ of execution issued by the Community Court may be suspended only by a decision of the Community Court of Justice.

In its judgment, the High Court found, that the findings of the ECOWAS Court are not subject to the domestic laws regulating foreign judgments in Ghana, such as the Courts Act 1993 (Act 459), the High Court (Civil Procedure) Rules 2004 (CI 47) as well as the Foreign Judgments and Maintenance Orders (Reciprocal Enforcement) Instrument 1993 (LI 1575). Thus, the enforcement of foreign judgments in Ghana underlies the principle of reciprocity. As such, the President of Ghana usually needs to designate the affected country in order to receive the benefit of the regime before the ruling can be enforced. ${ }^{765}$ However, most African States have not yet implemented the international treaties into their domestic laws. A positive development on this matter can only be recognized within the East African Community (EAC), where all Member States have incorporated the Treaty Establishing the East African Community in their national laws. ${ }^{766}$

The High Court concluded the ECOWAS is not included in the domestic regulations of enforcement of foreign judgments. ${ }^{767}$

However, according to Oppong, the Court could have used the common law regime being developed within Ghana on the enforcement of foreign law. ${ }^{768}$

\subsubsection{Conclusion on the enforcement of rulings}

Especially, the above-mentioned Mba $v$. the Republic of Ghana case illustrates the issues regarding the enforcement of the Court's judgments in human rights cases. Ghana is a dualist country and did not incorporate the Protocols of the ECOWAS Court into the legal system of Ghana. This decision of the ECOWAS Court appears to set a rather dangerous precedent since it appears that the judgments of the Court are rather meaningless which lack of legal force, which may lead to the fact that at least governments of dualist Member States may refuse to domesticate ECOWAS Protocols and in turn could circumvent ECOWAS jurisdiction. Interestingly, in the past Ghana was already confronted with similar issues of enforcement whereas such claims usually remain rare. In NML Capital, ${ }^{769}$ a seizure of an Argentinian warship

765 R.F. Oppong, 'The Higher Court of Ghana Declines to Enforce an ECOWAS Court Judgment Recent Developments', 25 Afr J Int'l \& Comp L (2017), 130.

766 Ibid.

767 Nwauche (2011), 187.

768 Oppong (2017), 130.

769 See: Republic v. High Court (Commercial Division) Accra, ex parte Attorney General and NML Capital Ltd. Civil Motion No. 15/10/2013, Supreme Court of Ghana, 20 June 2013. 
in Ghana at the instance of some probate creditors as a part of an action to enforce a foreign judgment of the International Tribunal of the Law of the Sea (ITLOS) ordering an immediate release of the ship was involved. The Supreme Court of Ghana, however, stated that since it is a dualist country any international law - even if it was already approved by the Parliament - is not enforceable unless it is incorporated into Ghanaian law. Since the UN Convention on the Law of the Sea is not part of Ghana's domestic legislation, any decision by the ITLOS remain unenforceable in Ghana. ${ }^{770}$ However, the recent decision of the Court ${ }^{771}$ involving journalists from The Gambia living in the exile and claiming that Gambian authorities would have violated their rights gives new hope for a move towards the enforcement of the Courts decisions. The Court declared in its judgment, that the actions of the Authority violated the journalists' right of freedom of expression, liberty and freedom of movement. ${ }^{772}$ The Court further stated that the Gambian criminal laws on libel, sedition and false news are obvious and gross violations of human rights, especially the right of freedom of expression. A reform of these criminal laws is already underway in The Gambia and thus, it may be hoped that the decision provides a new push towards the enforcement of ECOWAS Court judgments. ${ }^{773}$

\subsubsection{Failed backlash against the ECOWAS Court}

The ground-breaking ruling of the Court on the Manneh case and the case concerning the torture and detention of Musa Saidykhan were followed by an attempt to limit the jurisdiction of the Court. For instance, as a reaction to the ruling of the ECOWAS Court, the government of The Gambia responded to the Court arguing on the legal and political basis, that the suit would be 'an affront to [Gambian] sovereignty. ${ }^{774}$ In response, the Court stated in an interim ruling that it had considered all the governments' arguments and it rejected each of the arguments submitted. ${ }^{775}$

Consequently, the former President of The Gambia, Yahya Jammeh, wanted to find support within ECOWAS to give limitations on the jurisdiction of the ECOWAS Court. Thus, in September 2009, The Gambia submitted an official request to the ECOWAS Commission to revise the Supplementary Protocol of 2005. The request did contain a draft Supplementing Protocol with the following elements:

\footnotetext{
770 Oppong (2017), 128.

771 Federation of African Journalists and Others v. The Republic of The Gambia, ECW/CCJ/ APP/36/15, Judgment of 13 March 2018.

772 Ibid., paras 10 et seq.

773 Committee to Protect Journalists, 'ECOWAS court rules Gambia violated rights of journalists' (14 February 2018), available at: https://www.ifex.org/the_gambia/2018/02/15/ecowas-court/, (last visited: 6 September 2018).

774 Alter et al (2016), 297.

775 Alter et al (2013), 762.
} 
a) that with respect to human rights cases, the Court should only have jurisdiction in cases arising from international instruments ratified by the respondent country;

b) also in human rights cases, the ECOWAS Court's jurisdiction should be made subject to the exhaustion of domestic remedies;

c) cases should only be admissible if instituted not later than 12 months after the exhaustion of local remedies;

d) cases should not be anonymous;

e) the Court should not hear cases that are before other international mechanisms of settlement; and

f) to create appeals procedure. ${ }^{776}$

Many NGOs in West Africa criticized the proposal and stated that the beneficiary of the proposed Supplementary Act would be countries, such as The Gambia being one of 'the few countries of the African continent which has not yet ratified the United Nations Conventions Against Torture. Finally, a meeting of legal experts in Nigeria led to their recommendation to keep the Courts' powers on human rights. One week after the meeting of the legal experts the Council of Justice Minister followed their recommendations. ${ }^{777}$ After reaffirming the rulings, The Gambia continued to refuse to comply with the orders. However, even though The Gambia does not accept the authority of the Court, the legitimacy of the ECOWAS was bolstered as consequence of the failed backlash. With the swearing in of the seven judges that were recommended by the Judicial Council in 2013, the Court's 'formal human rights authority now rests on a more solid legal and political foundation. ${ }^{778}$

\subsection{Conclusion on the ECOWAS Court of Justice}

In general, it is notable that citizens of the ECOWAS Community do have direct access to the Court and therefore may be fully involved in the integration process.

Hence, in the beginning of 2017, the Vice President of the ECOWAS, Micah Wilkins, stated that '[a]ny citizen of the Member States of ECOWAS has the right to bring their case to this court. You do not have to be rich, poor, small, or a big person. Everyone in West Africa has the right to bring their case to the court, particularly human rights violation cases.' Further, he states that '[i]f we cannot reach out to the people they would not know and understand the workings of the court; and as a result, all efforts and money would be wasted because the court would not make its desired impact in the lives of the people. ${ }^{379}$

\footnotetext{
776 Alter et al (2015), 297 et seq.

777 Alter et al (2013), 763.

778 Alter et al (2015), 300.

779 A. Davis, 'West Africa: ECOWAS Court of Justice For Everybody', All Africa (30 January 2017), available at: https://allafrica.com/stories/201701300627.html, (last visited: 4 May 2017).
} 
Even though, the ECOWAS Court may function to the highest standards, it still needs to be ensured that the ECOWAS law is directly applicable domestic courts of the ECOWAS Member States. The success of regional integration within this area mainly depends on this factor.

It seems like Member States are aware of those needs. However, there seems to be a lack of political will regarding the implementation of direct applicability and effect on ECOWAS law.

But still, the ECOWAS Court can be described as a 'human right success story. ${ }^{1780}$ One of the reasons is that the ECOWAS Court is the most active regional court within Africa - after all, it decided around 100 cases in the period between 2005 and 2011. ${ }^{781}$

However, despite all the issues that ECOWAS is faced with, the regional institution may lead to liberation and the restoration of hope of the affected citizens. ${ }^{782}$

However, since the Court has the jurisdiction to decide on human right cases and is directly accessible by individuals, the ECOWAS Court constitutes a powerful alternative taking into consideration the African Commission whose communications are not binding to the parties and the African Court of Human and Peoples' Rights, which is not accessible by individuals.

During the years of enacting, the Court more and more strengthens its jurisdiction with regard to human rights. The case of SERAP Environment was ground-breaking with regards to human rights since the protection of the environment was included in the mandate of the ECOWAS Court. Furthermore, the case Koraou slavery (2008) remained one of the few cases, where an international court decided that a country - in this case Nigeria - needs to protect its citizens from slavery. For its judgment the Court was celebrated with comments like a 'human rights haven' and 'the African court has made history'..$^{783}$

However, the issue of enforceability, especially regarding dualist countries such as Ghana remains a challenge as has been seen in the case Mba v. the Republic of Ghana. Until today, ECOWAS does not provide for any legislation, which effectively regulates the enforceability of ECOWAS rulings. The ECOWAS Court may, however, use the common law regime in order to solve issues on the enforceability of its rulings. Examples from other African countries show, how such common law principles may be developed by the ECOWAS Court. One example for such development is the case Government of the Republic of Zimbabwe v. Louis Karel Fick ${ }^{784}$, which will be explained more detailed in Chapter 6. The Supreme Court of South

\footnotetext{
780 Ankrah (2013), 91.

781 Kane \& Motola (2008), 437.

782 Swart (2013), 444 et seq.

783 Davis (2017).

784 Government of the Republic of Zimbabwe v. Fick and Others (CCT 101/12) [2013] ZACC 22; 2013 (5) SA 325 (CC); 2013 (10) BCLR 1103 (CC), Judgment of 27 June 2013.
} 
Africa decided, that judgments of the Tribunal of the Southern African Development Community (SADC) are eligible to be enforced under the requirements of common law in South Africa.

The use of common law is however not without challenges, but due to the absence of any legislation, the ECOWAS Court may develop its own principles in order to ensure that its jurisdictions will not remain a meaningless paper. ${ }^{785}$

The failed backlash to the ECOWAS Court shows, that the Court already became a strong institution within ECOWAS since the proposal of the government of The Gambia to again limit the jurisdiction of the Court was not successful. Since the Ministers on ECOWAS level followed the recommendations of the legal experts not to limit the jurisdiction of the Court, it is obvious that the Court has political support within the region. Thus, it finally appears, that the ECOWAS Court may become a strong human rights court within the region if it ensures that Member States ensure the implementation of its jurisdiction.

\subsection{The Parliament of the Economic Community of West Africa}

The Community Parliament of ECOWAS was established by virtue of the provisions set out in Arts. 6 and 13 of the Revised Treaty of 1993.

However, the first legislature was only inaugurated in November 2000, in Bamako (Mali). In December 2001, the Authority of Heads of State and Governments decided that Abuja, the capital of Nigeria should become the headquarter of the Community Parliament. ${ }^{786}$

\subsubsection{The Composition of the Parliament of the Economic Community of West African States - the grounds for an independent institution}

Every Member State of ECOWAS shall be guaranteed a minimum of at least 5 seats. The rest of the remaining seats shall be shared among the Member States taking into account the population of each Member State. ${ }^{787}$

Consequently, Nigeria has 35 seats, Ghana 8, Côte d'Ivoire seven seats, Burkina Faso, Guinea, Mali, Niger and Senegal have six seats. The rest of the Member States, Benin, Cape Verde, the Gambia, Guinea-Bissau, Liberia, Sierra Leone and Togo enjoy five seats each. ${ }^{788}$

\footnotetext{
785 Oppong (2017), 131.

786 S. Shehu, 'The roles on ECOWAS Parliament on Regional Integration of the West African Sub-Region', 1 Int J Adm Gov 4 (2015), 119.

787 See: Art. 5 of the 1994 Protocol A/P.2/8/94 Relating to the Community Parliament.

788 S. Buthelezi, Regional Integration in Africa: Prospects and Challenges for the 21st Century (2006), 135.
} 
The representatives of each Member State are supposed to be elected by 'direct universal suffrage' by the citizens of the Member States. ${ }^{789}$

The Treaty provides for an exception of this principle stating that, depending on the time of the elections, the National Assemblies of the Member States or other, equivalent institutions are supposed to elect the Members from amongst themselves. ${ }^{790}$

Recently, Members of the National Parliaments elected the respective Members of the ECOWAS Parliament. The Authority shall determine the time of the currently existing transmission period. ${ }^{791}$

The Members of the Parliament are elected for the duration of five years. The period begins with the days the latter are sworn in during the transition period. ${ }^{792}$

During their membership in the Parliament, every representative enjoys parliamentary immunity in all ECOWAS Member States. Hence, they may not be summoned, arrested, prosecutes, detained or sentenced. The only exception of this regulation is the case of flagrante delicto. In order to apprehend a Member of the Parliament clearance must be sought from the Bureau of the Parliament. ${ }^{793}$

With a two-third majority, the Members of the Parliament have the opportunity, to achieve the suspension of a suit or detention order against a Member of Parliament.

\subsubsection{The internal structure of the Parliament}

The Community Parliament is divided into two wings - a political and an administrative wing.

The political wing of the Parliament provides for several internal institutions namely the Plenary, the Bureau and the Conference of the Bureau. Within the internal structure, the Plenary is the highest body within the Parliament whose decisions are generally binding to other institutions within the Parliament. Furthermore, the Plenary is entitled to adopt all the resolutions that are made of the Parliament and to forward them to the decision - making bodies within the Community, as per Arts. 2 and 6 of the Protocol.

According to Art. 16 of the Protocol, the Bureau is competent to govern the organ of the Parliament and comprises all Deputy Speakers.

The Deputy Speaker has administrative functions, which are restricted to internal procedures within the Parliament. Amongst other functions, the Bureau determines the draft agenda and all programs or business of the plenary sessions.

In addition, the Bureau is entitled to select - with the assistance of the so-called 'Committee on Selection' - the members of the several Standing Committees. ${ }^{794}$

789 See: Art. 71 (i) of the 1994 Protocol A/P.2/8/94 Relating to the Community Parliament.

790 See: Art. 71 (ii) of the 1994 Protocol A/P.2/8/94 Relating to the Community Parliament.

791 See: Art. 71 (ii) of the 1994 Protocol A/P.2/8/94 Relating to the Community Parliament.

792 See: Art. 7(2)(ii) of the 1994 Protocol A/P.2/8/94 Relating to the Community Parliament

793 See: Art. 9 (2) of the 1994 Protocol A/P.2/8/94 Relating to the Community Parliament.

794 Recently, a Committee on Administration, Finance, Budget control \& Audits, a Committee on Agriculture, Environment, Water resources and Sustainable development, a Committee on 
Lastly, the Conference of Bourreaux consists of The Speaker, Chairman or Deputy Chairman as well as the Rapporteur of each of the Standing Committees. The latter inter alia is responsible to draft the annual work-plan of the Parliament in accordance with the priority Community programs, as per Art. 16 of the Rules of Procedure.

The Parliament at the moment comes together in two ordinary sessions per year. Each of them may not exceed the period of three months. However, at the moment, the ordinary sessions are limited to two weeks. The first session is to be held in May, where else the second session in September, in accordance with Art. 13(1) of the Protocol.

Besides the ordinary sessions, extraordinary sessions may be held as result of the initiative of the Chairman of the Authority of Heads of State and Government or due to the absolute majority of its members, in line with Art. 13(2) of the Protocol.

During the second session, the Parliament usually determines its budget, as per Art. 18 of the Protocol.

\subsubsection{Engagement with citizens}

The Community Parliament has created an opportunity to engage with citizens of the Community. Due to the rules of procedure, the latter has the 'right to petition'. Rule 81(1) therefore is stating:

[A]ny citizen of the Community and any natural or legal person residing or having its registered office in a Member State, shall have the right to address, individually or in association with other citizens, a petition to Parliament on a Matter which comes within ECOWAS fields of activity and which affects him, her or it directly.

If the declaration becomes permissible, the affected Parliamentary Committee could issue either a resolution or an opinion that gets forwarded to the ECOWAS Commission for further notice. ${ }^{795}$

Even though the petitioner needs to be addressed itself by the issue, the citizens have a possibility to demand attention on human rights issues, without the need for judicial support.

Communications and Information technology, a Committee on Economic policies, Private sector \& NEPAD, a Committee on Education, Science and Technologies, a Committee on Gender, Women empowerment $\&$ Social Protection, a Committee on Health and Social services, a Committee on Human Rights, Child Protection \& Other vulnerable groups, a Committee on Infrastructure, Energy, Mine \& Industry; a Committee on Labour, Employment, Youth, Sport and Culture, a Committee on Legal and Judicial affairs, a Committee on Political affairs, Peace, Security \& Affairs peer review mechanism and a committee on Trade, Customs \& Free movement is installed. see: Official Website of the Parliament de la CEDEAO / ECOWAS http://parl. ecowas.int/committees/, (last visited: 13 September 2018).

See: Rule 82 (6), (7) of the Rules of Procedure of the ECOWAS Parliament. 


\subsubsection{The competences of the ECOWAS Community Parliament}

In accordance with Art. 6 (1) of Protocol A/P2/8/94, the Community Parliament has the opportunity to consider any matters with a connection to the ECOWAS Community. ${ }^{796}$ The Parliament is thus competent to give advice on issues that are related to human rights and fundamental freedoms, public health policies, sports and youth..$^{797}$

The Community's Parliament is eligible to make recommendations to the institutions and organs of the Community. ${ }^{798}$

However, the competence to give recommendations on human right matters may only become adequately enlightened if Art. 6(1) is read together with Article 6(2) of the Protocol. The latter States, that the opinion of the Parliament may become sought in 'respect for human rights and fundamental freedoms in their plenitude. ${ }^{3799}$

Nonetheless, the mandate on human rights does not counterbalance the lack on binding and compulsory decisions of the Parliament. ${ }^{800}$ Since the advice of the Parliament does not have a binding character, the institutions of the Community can naturally choose if they adopt the views of the Parliament or not.

\subsubsection{The Supplementary Protocol}

The competences of the Parliament, however, were developed over time. In 2016 a Supplementary Protocol was adopted by the ECOWAS Authority during its $50^{\text {th }}$ Ordinary Session extending the jurisdiction of the Parliament. ${ }^{801}$

Art. 4(2) of the Supplementary Protocol A/SP.3/06/06 amending Protocol A/P.2/8/94, indicated that the powers of the ECOWAS Parliament shall be progressively enhanced from advisory to co-decision making and subsequently to a law-making role in areas to be defined by the Authority'.

During the second and third legislature of the Parliament, an ad hoc Committee was established to gather proposals to enhance the powers of the Parliament. Therefore, the Committee also performed study visits to other regional parliaments such as the East African Legislative Assembly (EALA) and the European Parliament. ${ }^{802}$

\footnotetext{
796 See: Art. 4 of the 1994 Protocol A/P.2/8/94 Relating to the Community Parliament

797 Ankrah (2013), 89.

798 U. Terlinden, 'African Regional Parliaments - Engines of Integration and Democratisation?' (August 2005), available at: http://www.ulf-terlinden.de/docs/2005-08SADCPF_RAs_Lusaka. pdf, (last visited: 2 April 2017), 3.

799 C. Nwankwo, Legitimation of the Economic Community of West African States (ECOWAS): A Normative and Institutional Inquiry (2014), 198 et seq.

800 Ibid., 199.

801 See: Supplementary Protocol A/SP.3/06/06 Amending Protocol A/P2/8/94 relating to the Community Parliament.

802 Y. Itodo, 'ECOWAS Parliament salutes Ekweremadu on enhancement of its powers', Daily Post (28 February 2017), available at: http://dailypost.ng/2017/02/28/ecowas-parliament-salutes-
} 
In thereof proposal, the decision-making powers of the parliament have been increased significantly. The latter may deal with the matters being discussed within the Parliament in three different ways: through a simple opinion, mandatory assent and, co-decision-making next to co-legislation with the Council. ${ }^{803}$

The simple opinion is not of a binding character for any institution. However, the mandatory asset is of binding character to the requesting institution. Thus, the Parliament is competent to exercise oversight role over the institutions of ECOWAS.

The co-deciding and co-legislation with the Council, however, constitutes the highest level of exercise of influence of the Parliament. Nonetheless, the powers are restricted to issues being related to 'ECOWAS economic and monetary integration policies' ${ }^{804}$ During the extraordinary session in January 2017 , the speaker emphasized, that the views of the Parliament regarding budgetary questions are not binding to the Council of Ministers. ${ }^{805}$

Taking into consideration the Parliament of the European Union, it becomes clear, that the European Parliament also 'has come a long way from being a purely consultative assembly to being co-legislator with the Council of the European Union. ${ }^{806}$ The development of the legislative powers of the Parliament passed three States: consultation, co-operation and co-decision. Zhus, at the beginning of the integration process, the Parliament only had consultative powers within the European Union. The opinions that have been issued by the Parliament were not of binding character and hence, have been ignored many times by the decision-makers. ${ }^{807}$

Since ECOWAS has been involved in military interventions within the region, the Supplementary Act consequently strengths the role of the Parliament with regard to security matters. According to the Supplementary Protocol, the Parliament is authorized to participate in the meetings of the ECOWAS Mediation and Security Council at the ministerial and ambassadorial levels. ${ }^{808}$ However, the powers of the Parliament are still restricted to an observer status. The Parliament is only empowered in exceptional circumstances to ask the President of the Commission to 'activate the Conflict management mechanism. ${ }^{\text {'89 }}$

ekweremadu-enhancement-powers/, (last visited: 12 April 2017).

803 L. Boré \& F. Henkel, 'Disturbing a Cosy Balance? The ECOWAS Parliament's Rocky Road to Co-Decision', Friedrich Ebert Stiftung (2015); available at: http://library.fes.de/pdf-files/ iez/11185.pdf, (last visited: 3 April 2017), 5.

804 Ibid., 6.

805 See: Fourth Legislation Rules of Procedure of the ECOWAS Parliament of 2016.

806 Demeke (2004), 56.

807 Ibid; for more information on the legitimacy of International Organization through Parliaments see: M. Krajewski, 'International Organizations or Institutions, Democratic Legitimacity', in R. Wolfrum (ed), Max Planck Encyclopedia of Public International Law (2007). 
The Supplementary Act now officially recognized the role of the Parliament regarding the observation of elections within the ECOWAS States. In order to participate in the process, the latter can nominate some representatives.

Despite the legal limitations of the Parliament and its poor visibility, the ECOWAS Parliament managed to provide an avenue for popular participation in West Africa. ${ }^{810}$

With regard to political involvement, the Parliament was decisively involved in the peace process inter alia in The Gambia. ${ }^{811}$

\subsection{Conclusion on the ECOWAS Parliament}

Even though the Supplementary Act was implemented, the powers of the Parliament remain restricted. Nonetheless, the Parliament is now equipped with more powerful competences and thus gains importance regarding popular participation.

This may be the reason for some resistance to the reform stating that the changes implemented through the Supplementary Act would lead to unnecessary complications within the structural processes and practices that are tried and tested.

In addition to that, the Parliament lacks legitimacy, since the members of the Parliament are not elected on direct universal suffrage. Elections by direct universal suffrage certainly do require enormous funds, logistics and political will. Therefore, the ad hoc Committee decided not to implement this principle in the proposal, even though it would enormously boost the level of democracy. ${ }^{812}$

Certainly, one important change has been made in the new Act, since Members of Parliament do not hold a mandate in the national assemblies anymore. Thus, its Members ensure full engagement in parliamentary work.

With regard to the involvement in security matters, the enhancement of the Parliaments powers could be more intense. For instance, the Parliament could have become involved with regard to security matters.

Finally, the enhancement will only be implemented successfully, if the internal structure of the Parliament will be highly improved. It is certain, that more staff will be needed in order to establish inter alia legislative drafting.

Since the changes are modest, ECOWAS should take the chance to give the Parliament a stronger position and therefore a higher democratic legitimation.

810 N. O. Magbagbeola, 'Status of enhancement of powers of a regional Parliament: evidence from ECOWAS Parliament, Inter Parliamentary Union' (2016), available at: https:/www.asgp.co/ sites/default/files/ECOWAS\%20SG\%27s\%20Presentation\%20to\%20ASGP\%20Meeting\%20 in\%20October\%202016.pdf, (last visited: 5 April 2017), 6.

811 West Africa: Amb. Conteh Addresses Ecowas Parliament, All Africa (12 May 2017), available at: https://allafrica.com/stories/201705120746.html, (last visited: 17 September 2018).

812 J. Sendolo, 'Sensitize Liberians on ECOWAS' Mission', Liberian Daily Observer (2 February 2017), available at: https://www.liberianobserver.com/news/sensitize-liberians-on-ecowas-mission/, (last visited: 3 September 2018). 
Due to the opinion of Dr. Magbagbeola, the enhancement of the Parliament's powers would lead to high improvement of regional integration in West Africa, which would also improve the work of the African Union. ${ }^{813}$

Regarding the adoption of the new Supplementary Protocol, the Speaker of the Community Parliament Cisse Lo inter alia stated: '[...] It is now for each and every one of us to consolidate on this achievement and work harder in ensuring improvement in democracy in our community. ${ }^{814}$

Despite its lack of visibility, the Parliament managed to adopt some resolutions on important issues, including the domestication of the ECOWAS Supplementary Act on telecommunications into national legislations and the Economic Partnership Agreement between West Africa and the EU, the emergence of a common West African currency and the review of the criteria and modalities for elections in West Africa. ${ }^{815}$

Moreover, the ECOWAS Parliament was significantly involved in the advancement of peace in Liberia, Sierra Leone and Guinea, inter alia through the negotiations with the Liberians United for Reconciliation and Democracy rebels (LURD) $)^{816} .817$

However, with regard to the protection of the rule of law, especially the protection of human rights, the capacities of the Parliament still remain very limited. The expansion of the competences of the ECOWAS Parliament in order to become a fully-fledged institution is fully dependent upon the political will of the Heads of State and Government ${ }^{818}$, remaining the highest decision-making body within ECOWAS.

\footnotetext{
813 Adjolohoun (2013), 342 et seq.

814 Ibid.

815 Lokulo-Sodipe \& Osuntogun (2013), 270.

816 The Liberians United for Reconciliation and Democracy was a Liberian rebel group that was active from 1999 until the final resignation of Charles Taylor ended the Second Liberian Civil War in 2003. Until today, even though the group is formally dissolved, the interpersonal linkages of the civil war era remain a key force in internal Liberian politics. see: J. Brabazon, 'Liberia: Liberians United for Reconciliation and Democracy (LURD), The Royal Institute of International Affairs (February 2003), available at: https:/www.chathamhouse.org/sites/default/files/public/ Research/Africa/brabazon_bp.pdf (last visited: 13 September 2018).

817 S. A. Usman, 'Saraki tasks ECOWAS Parliament on regional integration, security, available' (13 July 2016) at: http://dailypost.ng/2016/07/13/saraki-tasks-ecowas-parliament-on-regionalintegration-security/, (last visited: 14 September 2018).

818 In accordance with Art. 7 of the Treaty, the Authority of Heads of States and Government is the supreme institution of the Community and is comprised of the Heads of State and Government of the respective member state. The Government of Heads of State acts by decisions and is responsible for the general direction and control of the Community, Art. $7 \& 9$ of the Treaty.
} 


\subsection{Final Conclusion on the ECOWAS}

ECOWAS has taken big steps towards the effective recognition of human rights and to enhance popular participation. With the recognition of those rights in the revised Treaty, human rights gained much more importance within the ECOWAS area.

In contrast, the progress of the ECOWAS Member States that has been made towards successful regional integration is very limited. Important procedures, such as a low trade flow among the ECOWAS Member States and undeveloped customs regulations, non-tariff barriers. ${ }^{819}$

A big concern remains, however, that the Authority of Heads of State and Government continues to have a great influence in all institutional matters with regard to the Court and the Parliament. With the Court, the influence of the Authority ranges from the appointment of the judges of the ECOWAS Court to the possible determination of its scope of jurisdiction.

Thus, the expectations regarding the Court always remained low at the time of its inauguration. This is due to the frequent violation of human rights in West Africa as well as regular destabilizing coups and civil unrest. It was thus expected, that the governments of the ECOWAS Member States would not accept an international court that has jurisdiction on human rights. ${ }^{820}$ In addition, it was also expected that politicians would implement some mechanisms to control the power of the Court.

It is also important to note that the ECOWAS Court did not give itself the mandate of jurisdiction on human rights through 'judicial law-making'. But it was politicians, bar associations, NGO's and also judges of the ECOWAS Court themselves, who engaged to convince the Member States to expand the jurisdiction of the Court.

As already noted above, the effective enforcement of the judgment of the ECOWAS Court however remains a big issue - the overcoming of this issue depends on the political will of the Heads of State and Government. If there is no attempt made towards a legislation ensuring the effective implementation of the Court's rulings, the Court may try - similar to South Africa - to ensure the effective enforcement through the development of common law. This may, however, increase the danger of a backlash and may lead to the decrease of political support in the region, which may finally lead to the fall of the Court. On the other hand, the last backlash which was tried consequently to the Manneh $v$. The Gambia case but finally failed. This event shows that the ECOWAS Court became a strong institution within ECOWAS, which at the moment has sufficient supporters. This may, however, change if the Court becomes too powerful within the region.

The ECOWAS Parliament continues to be ineffective in the promotion of the rule of law. It only provides for very few powers and is not competent to make any binding decision in matters that lead to a better promotion of the role of law.

\footnotetext{
819 Alter et al (2013), 739.

820 Ibid.
} 
In particular, the actual arrangement of the suffrage remains problematic. Currently, it does feel like that the Heads of State and Government would change the situation. Such development would need much funding as well as technical equipment and expertise. Furthermore, the reluctant expansion of the competences of the Parliament - despite for many calls to equip the Parliament with full powers - shows that Governments are still hesitant to accept a fully-fledged ECOWAS Parliament, which if implemented would reduce each State's sovereignty.

All in all, it appears that ECOWAS takes big steps towards an effective protection of the rule of law - inter alia through the implementation of the Protocol on Democracy and Good Governance. Especially, the Court has the tools to become a fully effective human rights institution, which is already a good sign for the region taking into consideration that the Heads of State and Government decided to extend the jurisdiction of the Court until it became competent to hear human rights claims of individuals. 



\section{Chapter 5: \\ The Southern African Development Community (SADC)}

\subsection{Introduction}

After the presentation of the subregional agreement in West Africa, this chapter will focus on the Southern Africa Development Community (SADC).

The Southern African Development Community is a supranational community in Southern Africa, which achieved enormous liberalization and initiated a meaningful process of restructuring during the last two decades. ${ }^{821}$

Currently, SADC encompasses fourteen Member States ${ }^{822}$ and a population of around 200 million citizens. ${ }^{823}$ The SADC region, in general, provides for a low economic growth rate of $\max .4 \%$ but at the same time features a high population

821 F. Müller, 'Storming, Norming, Performing: Implications of the financial crisis in Southern Africa', Goettingen Journal of International Law (2010), 168, 169.

822 The current member states are D.R. Congo, Tanzania, Malawi, Madagascar, Zambia, Angola, Zimbabwe, Mozambique, Namibia, Botswana, Swaziland, Lesotho and South Africa. see: Official Website of the Southern African Development Community (SADC), available at: https://www.sadc.int/, (last visited: 9 September 2018).

823 Southern African Development Community Parliamentary Forum, Strategic Plan of 2006-2010, 9. 
growth of $2.7 \%{ }^{824}$ It consists of very different economies - on the one hand, it includes the strongly developing countries of South Africa, Namibia, Botswana and Mauritius, while on the other hand, has some of the least developed countries in the world, such as Malawi and Tanzania. ${ }^{825}$ Furthermore, the level of democracy among SADC members varies considerably: while Botswana, Mauritius and South Africa have quite stable democracies, other Member States such as the Democratic Republic of Congo and Zimbabwe do not provide such structures. ${ }^{826}$

\subsection{Historical background of the Southern African Development Community (SADC)}

The idea of a regional agreement covering the area of Southern Africa began to develop even before the end of apartheid in South Africa.

The Southern African Development Coordination Conference (SADCC) preceded the SADC. ${ }^{827}$ A memorandum of understanding, signed by the countries described as 'front line States' ${ }^{\text {'28 }}$ namely, Angola, Botswana, Lesotho, Malawi, Mozambique, Swaziland, Tanzania, Zambia and Zimbabwe, on 20 July 1982 at Harare, Zimbabwe, was the legal basis to establish the SADCC. ${ }^{82}$ The objective of SADCC was to end colonialism and to liberate the SADCC region from racism and white minority-rules. ${ }^{830}$

The former President of Zambia, Kenneth Kaunda, undertook the main initiative that resulted in the establishment of SADCC on 4 July 1974 in Dar es Salaam, by advertising for a 'transcontinental belt of independent and economically powerful nations, from Dar es Salaam and Maputo on the Indian Ocean to Luanda on the Atlantic' ${ }^{831}$

Other academics, however, argue that the foundation process started with the meeting of the Foreign Ministers of the frontline States in Gaborone in May 1979. ${ }^{832}$ Apart from that, the possible independence of Zimbabwe - which was the

824 C. Mataranyika, Leadership orientation workshop for the National Assembly of Mauritius (2008), 25.

825 Müller (2010), 174.

826 W. Breytenback, 'Democracy in the SADC region', 11 African Security Review (2002), 87, 89.

827 A. Saurombe, 'The role of SADC institutions in implementing SADC Treaty Provisions dealing with regional integration', 15 Potchefstroom Elec LJ (2012), 454, 456; See also: L. Nathan, Community of insecurity: SADC's struggle for peace and security in Southern Africa (2016), 17.

828 Hartzenberg (2011), 5.

829 K. Mhone,' Law as a Factor for Regional Integration: SADCC: Problems and Prospects', 24 The Comp \& Int'l Jrn of SA 3 (1991), 379.

830 F. Maonera, 'Zimbabwe: which way: COMESA or SADC customs union?', Trade and Development Studies Centre (2007), 9.

831 J. Jemielniak, L. Nielsen \& P. Olsen, Establishing Judicial Authority in International Economic Law (2016), 100.

832 C. Hill, 'Regional co-operation in southern Africa', 82 African Affairs 327 (1983), 215. 
only country in the region, excluding South Africa, which had a developed economy and a more or less developed infrastructure - also gave impetus to the establishment of SADCC. ${ }^{833}$

Originally, the idea was to establish international cooperation for economic liberation as well as collective self-dependence. SADCC also wanted to eliminate the economic domination of apartheid in South Africa by the creation of economic development in the region of Southern Africa. ${ }^{834}$ The Member States of SADCC had stringent protectionist trade barriers which many times alienated importers. ${ }^{835}$ However, SADCC was neither founded with the objective to become free trade area nor a customs union but was rather designed with the objective to cooperate in matters of regional integration, by identifying developmental projects, organizing feasibility studies and attempting to find local funding bodies. ${ }^{836}$

After the establishment of the Democratic Republic of South Africa and the resolution of the conflicts in Angola and Mozambique, the region of Southern Africa tried to foster economic co-operation, with the awareness of the importance of the integration of their economies. ${ }^{837}$ Consequently, the Southern African Development Community (SADC) was founded in 1992 with the signing of the SADC Treaty. ${ }^{838}$

Meanwhile, various other protocols with regard to politics, security, mining, energy, health, education and gender, among others, were also signed. ${ }^{839}$ When apartheid ended in South Africa, the country finally joined SADC in 1994 whereas Mauritius did so one year later. In 1997 the Democratic Republic of Congo joined, followed by Madagascar in 2005 and Seychelles in 2007. ${ }^{840}$ In 2001, a process of restructuring of SADC took place, with the aim of improving the efficiency and effectiveness of the regional trade agreements programs and policies. ${ }^{841}$

\footnotetext{
833 Mhone (1991), 380.

834 Ibid., 379.

835 Ibid.

836 D. van der Merwe, 'Economic cooperation in Southern Africa: structures, policies, problems', 24 Comp \& Int LJ of S Africa (1991), 386, 391.

837 H. T. Rosalind, 'The World Trade Organisation and Southern African trade relations', 3 Law, Democracy and Development (1991), 105.

838 O. C. Ruppel, 'Land Issues before the Southern African Development Community Tribunal: a case for human rights?' in: B. Chigara (ed), Southern African Development Community land issues: towards a new sustainable land relations policy (2013), 87, 91.

839 L. Nathan, 'The Disbanding of the SADC Tribunal: A Cautionary Tale', 35 Hum Rts Q (2013), 870,872 .

840 C. Peter-Berries, Regional Integration in Southern Africa - A Guidebook, on behalf of Federal Ministry for Economic Cooperation and Development, Germany (2010), 73.

841 Maonera (2007), 9.
} 


\subsection{Objectives of the Southern African Development Community}

The Southern African Development Community, similar to the African Union and other subregional agreements defined its objectives in its Treaty.

The objectives of SADC, pointed out in Art. 5 of the SADC Treaty, are to inter alia:

$[\mathrm{P}]$ romote sustainable and equitable economic growth between Member States, consolidating, defending and maintaining the democracy, peace, stability and security; promoting common political values, systems and other shared values that are transmitted through democratic, legitimate and effective institutions, and mainstreaming gender in the process of community building. ${ }^{842}$

To achieve these goals, the SADC Treaty provides for several strategies regarding economic integration, such as the 'development of regional and national policies that progressively eliminate obstacles to the free movement of people, capital, labour, goods and services. ${ }^{343}$ With regard to the matters of peace and security, the Treaty aims to achieve the harmonization of political policies and international relations of the respective Member States. ${ }^{844}$

Art. 6 of the SADC Treaty provides a list of different undertakings that Member States shall implement in their respective domestic legal framework, such as the adoption of measures with the intention to achieve the goals of the SADC and to ensure non-discrimination against citizens within the territory of SADC. ${ }^{845}$ Hence, to ensure the achievement of the goals outlined in the SADC Treaty, several legal and institutional instruments have been put into place.

With the adoption of the Regional Indicative Strategic Development Plan (RISDP) by the SADC Summit in 2003, SADC proclaimed the following ambitions with regard to regional integration:

- a free trade area by 2003,

- completion of negotiations for the SADC Customs Union by 2010,

- completion of negotiations for the SADC Common Market by 2015 ,

- SADC Monetary Union and SADC Central Bank by 2016,

- launch of a regional currency by $2018 .{ }^{846}$

842 M. J. Nkhata, 'The Role of Regional Economic Communities in Protecting and Promoting Human Rights in Africa: Reflections on the Human Rights Mandate of the Tribunal of the Southern African Development Community', 20 Afr J Int'l \& Comp L (2012), 87, 92.

843 See: Art. 5(2)(d) of the 1992 Treaty of the Southern African Development Community; see also: Nathan (2016), 23.

844 See: Art. 5(2)(a) and (h) of the 1992 Treaty of the Southern African Development Community; see also: Nathan (2016), 23.

845 Nkhata (2012), 92.

846 Ruppel (2013), 91. 
Many voices characterized these aims as overambitious. ${ }^{847}$ At the time of writing, the Customs Union has not yet been established, resulting in the fact that none of the other plans will be achieved on time either. ${ }^{848}$ However, with the implementation of the Free Trade Area in 2008, the charging of high tariff on imports should be abandoned, however high tariffs on goods within the region of Southern Africa are still reported. ${ }^{849}$

Notwithstanding the fact that the RISDP is not legally binding within the SADC framework, it has a strong political legitimacy and is accepted as a 'strategic plan for SADC's integration. ${ }^{850}$ Although the SADC Treaty affects the sovereignty of the Member States, it was established through negotiation and is generally regarded only as a 'freely concluded agreement. ${ }^{\text {'51 }}$

In 1996, SADC launched the Organ on Politics, Defence and Security (OPDS) in order to ensure peacekeeping within the SADC region. Consequently, the Protocol on Politics, Peace and Security Co-operation was enacted on 14 August 2001, it was supposed to provide a legal framework and the objectives of the SADC Organ on Politics, Peace and Security.

The institution has several objectives such as (a) promoting peace and security across Southern Africa; (b) protecting SADC region from instability due to the breakdown of law and order; (c) developing a common foreign policy throughout the region; (d) cooperation on matters relating to security and defense. Furthermore, the mandate of this institution includes human right matters as well as the development of democratic institutions and practices. ${ }^{852}$

With the goal of implementation of these objectives, Arts. 3 and 11 of the Protocol on Politics, Defence and Security Co-operation provide an operating structure of the organ. Art. 11 of the Protocol further provides for mechanisms on conflict resolution.

Until today, OPDS mainly solved issues on security. ${ }^{853}$ During a Summit of the OPDS held in 1996, the situation in Angola was analyzed. The Summit noted that 'the prevailing situation in Angola is the remaining major obstacle total regional stability.' ${ }^{854}$ Thus, as a consequence, a call was made to rebel UNITA

847 J. Mapuva \& L. Muyengwa-Mapuva, 'The SADC Regional Bloc: What Challenges and Prospects for Regional Integration', 18 Law, Democracy \& Dev (2014), 22, 25.

848 J. Kleis, African Regional Community Courts and their Contribution to Continental Integration (2016) 87.

849 A. Saurombe, 'An Analysis and Exposition of Dispute Settlement Forum Shopping for SADC Member States in the Light of Suspension of the SADC Tribunal', 23 South African Mercantile Journal 3 (2011), 392, 397.

850 Hartzenberg (2011), 6.

851 Saurombe (2012), 454.

852 H. Chitimira \& P. Mokone, 'The Functions of Selected Human Rights Institutions and Related Role-Players in the Protection of Human Rights in Zimbabwe', 19 Potchefstroom Elec LJ (2016), 1, 25.

853 Viljoen (1999), 205.

854 Ibid. 
forces in order to fulfill its commitments in terms of the Lusaka Protocol. In addition, Amnesty International argued that this organ should function as an 'effective means to ensure uniform training in the protection of fundamental rights within the sub-region. ${ }^{1855}$

The OPDS also includes human rights-related matter since one of its objectives is the promotion enhancement of the development of democratic institutions and practices within Member States. Furthermore, OPDS is enabled to encourage regarding the observance of human rights as provided for in the Charters and Conventions of the AU as well as the United Nations. ${ }^{856}$

Until today, the OPDS struggles to enforce the Protocol in some SADC Member States such as the Democratic Republic of Congo, Zimbabwe and Angola. For instance, the OPDS fails to take any action against the complaints regarding civil or human rights violations in Zimbabwe. ${ }^{857}$

\subsection{Organs of the Southern African Development Community (SADC)}

Similar to the other regional and subregional entities on the continent, the Southern African Development Community (SADC) provides for several objectives within distinctive fields of law.

Thus, with the adoption of the SADC Treaty, the legal foundation was laid to establish several institutions within the subregional community.

The institutions of SADC are the Summit of Heads of State or Government, the Organ on Defense and Security, the Tribunal, the Council of Ministers, the Sectoral \& Cluster Ministerial Committees, the Standing Committee of Senior Officials, the Secretariat, and the National Committees, Art. 9 of the SADC Treaty.

The SADC Summit is the policy-making organ of SADC and controls the several functions and achievements of the Community, Art. 10(1). The Summit is made up of all Heads of State and Government. The selection of a chairman is based on a Troika system that is comprised of the Deputy Chairperson, the Summit Chairperson and the previous Chairperson, Art. 9a(2). The Summit generally meets twice a year, Art. 10(5).

The Organ on Politics Defense and Security is also based on a Troika system. In accordance with Art. 9(a)(1), the Troika system shall further apply to the Council of Ministers, the Sectoral Cluster and Cluster Ministerial Committees and the Standing Committee of Officials.

855 See: para. 10 of the 1996 Communiqué of the Organ on Politics, Defence and Security (OPDS).

856 Viljoen (2007), 516.

857 Chitimira \& Mokone (2016), 25. 
The Organ shall provide for a Ministerial Committee, which shall consist of the ministers of foreign affairs, defense, public security, state security and police, Art. 10(4). The functions and structures are regulated on the Protocol on Politics, Defense and Security Cooperation, Art. 10(6).

In addition, SADC provides for a Tribunal that ensures the adherence to as well as the interpretation of the SADC instruments, in accordance with Art. 16(1). The functions, composition, and powers are to be regulated in a separate protocol, as per Art. 16(2). The Council of Ministers is mandated to oversee the function of the SADC and aims to ensure the proper implementation of the policies. In general, as laid in Art. 11(1), the Council of Minister is composed of the Ministries of Foreign Affairs, Economic Planning and/or Finance. Under Art. 11(4), the Council usually meets four times a year. In order to oversee the several areas of integration of the objectives as well as the implementation of the Regional Indicative Strategic Development Plan, SADC provides for Cluster Ministerial Committees. Currently, the Cluster Committees are as follows: Ministers responsible for Trade, Industry, Finance and Investment; Ministers responsible for Infrastructure and Services; Ministers responsible for Food, Agriculture, Natural Resources and Environment; Ministers responsible for Social and Human Development and Special Programs (HIV and AIDS; education, labor; employment and gender); Ministers responsible for Politics, Defense and Security; and Ministers responsible for Legal Affairs and Judicial matters, as per Art. 12(2). The Committee of Senior Officials is the Technical Advisory Committee to the Council of Ministers and consists of one Member Secretary or an official of the equivalent rank of each Member State, in accordance with Art. 13(1), (2). Pursuant to Art. 13(6), the Committee meets at least four times a year.

Besides that, the SADC Secretariat is responsible, in line with Art. 14(1) for strategic planning, coordination and the management of SADC programs and is the principle executive organ of SADC. The Secretary is responsible for the implementation of the decisions issued by the Summit and the Council with regard to policies. The Executive Secretary heads the Secretariat, as per Art. 14(2).

The SADC National Committees are mandated to provide input at national levels with the preparation of regional policies and strategies, conforming to Art. 16a(4). The Committees besides that are responsible for the initiation of SADC projects. Key stakeholders from government, civil society and private sector form part of the Committees, as per Art. 16a(1), (13). 


\subsection{The Tribunal of the Southern African Development Community}

As mentioned earlier, the SADC Treaty provides for the establishment of a SADC Tribunal as the juridical institution of the community. The initial idea on the establishment of the SADC Tribunal was to ensure an effective regional co-operation as well as integration..$^{558}$

\subsubsection{Historical Background on the Tribunal of the Southern African Development Community}

The SADC Tribunal was established in 1993, in line with the adoption of the SADC Treaty. Based on Art. 9(g) of the SADC Treaty, which provides for the establishment of various institutions to govern SADC, the Tribunal was formed with the objective to become a SADC institution. ${ }^{859}$ The judges, however, were only appointed in 2005 in accordance with the provisions laid in Art. 4(4) of the SADC Protocol on Tribunal and its Rules of Procedures. ${ }^{860}$

When the Protocol to the Tribunal was signed, many SADC Member States determined that the Protocol on the Tribunal was not ratified by a two-thirds majority of Member States as provided by Art. 22 of the Treaty, ${ }^{861}$ hence the SADC Tribunal would be either illegal or at least not legally instituted. ${ }^{862}$ In this matter, especially Zimbabwe had strong objections. ${ }^{863}$

The participants of the SADC Summit signed the Protocol establishing the Tribunal on 7 August 2000. ${ }^{864}$ In this context, it seems condemnable that Zimbabwe nominated a Member of the Tribunal, Justice Antonia Guvava. This action does not appear to be in accordance with the claim that the SADC Tribunal is not officially existent. In 2009, Zimbabwe declared that it seeks to remove Guvava from the Court but no official action was taken. ${ }^{865}$

However, in 2002, the SADC Treaty was amended, and the Treaty as amended made an explicit reference to the Tribunal Protocol. Most importantly, the content of Art. 16(2) was amended and now emphasizes that the Tribunal Protocol 'shall, notwithstanding the provisions of Art. 22 of this Treaty, form an integral part of this

\footnotetext{
858 Mapuva \& Muyengwa-Mapuva (2014), 32.

859 Nkhata (2012), 93.

860 M. Beukes, 'Zimbabwe in the Dock: The Southern African Development Community (SADC) Tribunal's First Decision Foreign Judicial Decisions, 33 S Afr YB Int'L (2008), 228 et seq.

861 T. Hondora, 'The Establishment of the SADC Tribunal: Troubled Beginnings' (2010), 5.

862 O. Jonas, 'Neutering the SADC Tribunal by Blocking Individuals' Access to the Tribunal', 2013 International Human Rights Law Review (2013), 294, 296.

863 Hondora (2010), 5.

864 See: Art. 10(1) of the 1992 Treaty Establishing the Southern African Development Community.

865 MR Phooko, 'No longer in suspense; clarifying the human rights jurisdiction of the SADC Tribunal', 18 Potchefstroom Electronic Law Journal 3 (2015), 531, 548.
} 
Treaty. ${ }^{\prime 866}$ The meaning of that phrase could be interpreted, by taking into consideration the principles of the Vienna Convention, that the Protocol shall form part of the SADC Treaty without complying with the requirements set up by Art. 22. ${ }^{867}$ On 3 October 2002, the Summit declared its recognition that the Protocol on the Tribunal entered into force on 14 August $2003 .{ }^{868}$ The amendment aimed to achieve a 'renewed energy in the integration of the community, making the Protocol on the Tribunal an integral part of the Treaty and thus automatically applicable to all Member States. ${ }^{869}$ This goal was confirmed with the adoption of an article in the amendment stating that one of SADC's objectives was to 'consolidate, defend and maintain democracy, peace, security and stability. ${ }^{970}$

Later, in 2005, the SADC Tribunal was set up in Windhoek, Namibia, where its headquarter is located. The establishment of the Tribunal indicated the impression that the Member States adopted the SADC's principles as well as subordinate their sovereignty to regional institutions, such as the SADC with its Tribunal. ${ }^{871}$ Apart from English, the working languages adopted were Portuguese and French. ${ }^{872}$ Art. 16(3) of the SADC Treaty as well as Art. 4 of the SADC Protocol provide that 10 judges are officially nominated, each for five years renewable, which has to be determined in common by the governments of the SADC Member States. After the appointments, the Council of Ministers has to announce five judges, who sit on the Tribunal regularly. ${ }^{873}$ Between 2005 and 2010, the Tribunal has been very active, since it heard 30 cases and also failed a judgment on at least 24 of them. ${ }^{874}$ Cases decided by the Tribunal include inter alia issues on the distribution of land ${ }^{875}$ as well as employment ${ }^{876}$ issues.

\footnotetext{
866 D. Matyszak, The dissolution of the SADC Tribunal, Research and Advocacy Unit (2011), 1.

867 Gathii (2011) 291.

868 Hondora (2010), 6.

869 Saurombe (2011), 395.

870 See: Art. 5(a)Treaty of the 1992 Treaty Establishing the Southern African Development Community.

871 Nathan (2013), 874.

872 Saurombe (2011), 395.

873 Ruppel (2013), 93.

874 J. Sarkin, 'A Critique of the decision of the African Commission on Human and Peoples' Rights permitting the demolition of the SADC Tribunal: Politics versus Economics and Human Rights', 24 Afr J Int'l \& Comp L (2016), 215, 218.

875 See: Mike Campbell (PvT) Ltd. and 78 Others v. Republic of Zimbabwe, 2008 SADCT 2, Judgment of 28 November 2008.

876 See: Bookie Monica Kethusegile-Juru v. The Southern African Development Community Parliamentary Forum, 2010, SADCT 2, Judgment of 5 February 2010.
} 


\subsubsection{Jurisdiction on of the Tribunal of the Southern African Development Community}

The SADC Tribunal, which was finally set up in 2005 , had a broad jurisdictional mandate.

Neither the SADC Treaty nor the SADC Protocol explicitly gives jurisdiction on human rights issues to the SADC Tribunal. Art. 16 of the SADC Treaty states that the Tribunal should be 'constituted to ensure adherence to, and the proper interpretation of, the provisions of this Treaty.' If a Member State fails to comply with obligations under the SADC Treaty, the Summit thus is mandated to impose sanctions upon the respective State. ${ }^{877}$ Thus, the jurisdiction of the Tribunal merely has its focus on disputes involving issues on subregional integration or issues regarding the administration on SADC level. However, the latter clarified and justified the application of legislation on human rights. For instance, the Gondo case $e^{878}$ shows that the Tribunal is willing to protect the fundamental principles of human rights that are provided for in the SADC Treaty by referring to the African Charter on Human and Peoples' Rights. ${ }^{879}$

\section{a) Mike Campbell (PvT) Ltd. and another v. Republic of Zimbabwe}

In Mike Campbell (Pvt) Ltd. and another v. The Republic of Zimbabwe, the Tribunal, however, decided that it was competent to hear cases involving human rights.

The applicants in this case requested the Tribunal to 'make an order for interim relief pending the resolution of their substantive application.' A Zimbabwean-registered company, Mike Campbell (Pvt) Ltd. claimed on 11 October 2007 that the land reforms violated human rights. The reason for the claim was the first attempt to grab the Campbell farm, without paying any compensation. Later in October and November 2007, an invasion of the war-veterans took place. In 2006, after the coming into force of the Amendment Act No. 17, Campbell worked against the allocation of his farm to Nathan Shamuyarira, the former Minister of Land, Land Reform and Resettlement. ${ }^{880}$ At the time the applicants approached the Tribunal, they also claimed before the Supreme Court of Zimbabwe ${ }^{881}$ being the 'apex court' within Zimbabwe. ${ }^{882}$

\footnotetext{
877 Saurombe (2012), 468.

878 Barry L.T. Gondo \& Others v. The Republic of Zimbabwe, Case No. (T) 05/2008.

879 A. Afadameh-Adeyemi, 'Barry Gondo \& 8 Others v The Republic of Zimbabwe, SADC (T) 05/2008', 1 SADC Law Journal (2011), 203, 204.

880 Ruppel (2013), 101.

881 The Supreme Court of Zimbabwe decided in the matter of Mike Campbell (Pty) Ltd. v. Minister of National Security Responsible for Land, Land Reform and Resettlement ((SC 49707), 1/2008, Judgment of 21 January 2008), dismissing the applicants "case, inter alia, on the ground that that the question of what protection an individual should be afforded in the Constitution in the use and enjoyment of private property, is a question of a political and legislative character, and that as to what property should be acquired and in what manner is not a judicial question". Jonas (2013), 298.
} 
The main issue in this case was 'the legal propriety of the compulsory acquisition of the applicants' agricultural lands by the respondent. ${ }^{983}$ The complainants argued that the land reform program established by the Republic of Zimbabwe violated several principles of the SADC Treaty and of the Zimbabwean Constitution. ${ }^{884}$

The SADC Tribunal ruled that the action of the Zimbabwean government namely the disallowing of legal appeals against eviction orders of farms - was illegal. ${ }^{885}$ The Tribunal instructed Zimbabwe to pay compensation to the farmers of confiscated farms. ${ }^{886}$

aa) Background and Context of the Campbell case

The case was submitted in the context of the Zimbabwean land reform. In 2000, some Zimbabwean citizens who fought for the liberation of the country in the 1970 s started a violent campaign of invading and occupying white-owned land and farms. Until those days, the land question had always been a political and economic issue. ${ }^{887}$ With regard to the agricultural potential, Zimbabwe was divided into two zones: the land privately owned by white farmers, which had a high agricultural production potential and the black tribal trust land, consisting of semi-desert soils with very low agricultural production potential'. 888 The forcible removal of the indigenous black population from their traditional land during the colonial period created this situation. ${ }^{889}$ Following the adoption of various legislative acts, black farmers were dispossessed of their land without receiving any compensation and were forced to occupy land with the least productivity and above all the least rainfall. ${ }^{890}$ The Land Apportionment Act (1930) gave 30 percent of the existing agricultural land to the 1.1 million Africans and 51 percent to the 50, 000 whites living in Zimbabwe. ${ }^{891}$

In 2005 the Constitution of Zimbabwe was changed (The Constitution of Zimbabwe Amendment Act No. 17) and inter alia provided that farmers could be dispossessed of their land with neither receiving any compensation nor having the

\footnotetext{
883 Nkhata (2012), 93.

884 MCC Mkandawire, 'The SADC Tribunal perspective on enforcement of judgments: state support and cooperation', 3 Commonwealth Law Bulletin (2010), 567, 570.

885 Peter-Berries (2010), 99.

886 A. Moyo, 'Defending human rights and the rule of law by the SADC Tribunal: Campbell and beyond', 9 African Human Rights Journal (2009), 590, 595.

887 Nathan (2013), 874.

888 B. Chigara, 'Introductory note to Southern African Development Community (SADC) Tribunal: Mike Campbell (PVT) and Others v. Republic of Zimbabwe', International Legal Materials (2009), 530 .

889 Ibid.

890 Jonas (2013), 298.

891 Chigara (2009), 530 et seq.
} 
option to claim the misappropriation before any national court. ${ }^{892}$ The Zimbabwean Government was only prepared to pay compensation for some improvements made on the land. ${ }^{893}$

Any matters concerning land and land reforms will always remain a constitutional issue since the economy of Zimbabwe is mostly based on agriculture. Thus, any disputes on the distribution of land in Zimbabwe will always remain of great importance. ${ }^{894}$

\section{bb) Findings of the SADC Tribunal}

The SADC Tribunal found that the land reform was discriminatory, failed to give the applicants adequate access to justice and also violated international law since it did not provide any compensation. ${ }^{895}$ Thus, the SADC Tribunal ruled, that white farmers of Zimbabwe are eligible to keep their farms ${ }^{896}$ According to the findings of the Tribunal, the implementation of the Constitution of Zimbabwe Amendment Act 17, does not comply with the obligations. ${ }^{897}$

It argued that Art. 4(c) of the SADC Treaty required Member States to act in accordance with the principles of human rights, the rule of law and democracy. ${ }^{898}$ Thus, the Tribunal determined that Zimbabwe violated two of those principles by adding Amendment 17 to the Constitution: the principle of rule of law (with regard to the refused access to national tribunals) and the principle of human rights (with regard to the right of a fair hearing). ${ }^{899}$

On receiving the judgment of the Tribunal, the applicants in the above case took it back to Zimbabwe, as provided in Art. 32(1)(3) to be read together with Rule 74 of the Protocol of the Tribunal. Since Zimbabwe did not adopt the judgment of the SADC Tribunal, the complainants went back to the Tribunal, referring to Art. 32(4) of the Protocol of the Tribunal. Hence, the Tribunal found that the Republic of Zimbabwe did not comply with the ruling of the Tribunal made in its first decision. ${ }^{900}$

892 M. Dube \& R. Midgley, 'Land reform in Zimbabwe: context, process, legal and constitutional issues and implications for the SADC region', in A. Bösl et al (eds), Monitoring Regional Integration in Southern Africa Yearbook (2008), 3.

893 A. T. Magaisa, 'Constitution Flash- Agricultural Land in the draft Constitution' (August 2012), available at: http://www.cfuzim.org/index.php/newspaper-articles-2/constitution/2847constitution-flash-agricultural-land-in-the-draft-constitution, (last visited: 8 June 2016).

894 J. Scharfenberg, Die regionalen Gerichtshöfe der Südafrikanischen Entwicklungsgemeinschaft (SADC) und der Ostafrikanischen Gemeinschaft (EAC) (2014), 137.

895 Mkandawire (2010), 570.

896 Chigara (2009), 547.

897 Saurombe (2011), 396.

898 L. Nathan, 'Solidarity triumphs over democracy - the dissolution of the SADC Tribunal', The United Nations and Regional Challenges (2011), 127.

899 Moyo (2009), 601.

900 Mkandawire (2010), 571. 
After the first ruling of the Tribunal, the Minister of State for National Security, Lands, Land Reform and Resettlement, stated the Tribunal was 'day-dreaming because we are not going to reverse the land reform exercise. There is nothing special about the 75 farmers and we will take more farms. It is not discrimination against farmers, but correcting land imbalances. ${ }^{.901}$ Furthermore, the President of the Republic of Zimbabwe, Robert Mugabe called the Tribunal to be an 'exercise in futility.' This statement came in relation with the decision of the Zimbabwean High Court that found, that the findings by the Tribunal are 'null and void because it was ultra vires'. ${ }^{902}$

When Zimbabwe still ignored the findings of the Tribunal, the Tribunal submitted a number of complaints to the SADC Summit to secure the implementation of its findings. The Summit itself did not impose any sanctions ${ }^{903}$ to enforce compliance by Zimbabwe. Zimbabwe then was faced with a politico-legal challenge ${ }^{904}$ Thereupon it was ruled by a Zimbabwean Court that SADC Tribunal findings did not apply to the country. ${ }^{905}$ The representatives of Zimbabwe argued that the Tribunal was not operational due to the non-fulfillment of the requirements set out in Art. 22 of the SADC Treaty, Zimbabwe argued, that it did not ratify the Protocol to the Tribunal. However, Art. 22 of the SADC Treaty states that '[e]ach Protocol shall be binding only on the Member States that are party to the Protocol in question.' Moreover, Art. 16 of the Treaty states that: 'The composition, powers, functions, procedures and other related matters governing the Tribunal shall be prescribed in the Protocol, which shall, notwithstanding the provisions of Art. 22 of the Treaty, form an integral part of this Treaty, adopted by the Summit'. ${ }^{906}$ Consequently, regardless of a ratification by the Member States, the Protocol becomes binding if it is officially adopted by the Summit. ${ }^{907}$

The decision by the Tribunal shows the readiness of the latter to 'recognise, promote and protect human rights of individuals in their territories [...]. .908

After the first preliminary injunction against Zimbabwe, which had the purpose to prevent Zimbabwe from evicting the applicant, the supporters of Zimbabwe's President Mugabe kidnapped Campbell and his son-in-law and burned their farm. ${ }^{909}$

cc) Louis Karel Fick and another v. Republic of Zimbabwe

The case of Fick and another v. The Republic of Zimbabwe $e^{910}$ was brought forward as consequence of the non-compliance of Zimbabwe with the judgment in the Campbell case.

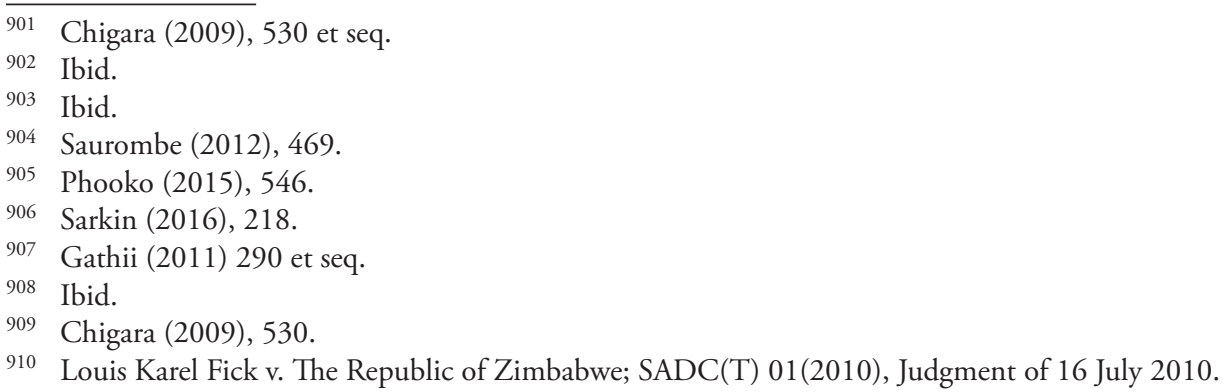


The submission of the case to the SADC Tribunal has been made under the provisions of Art. 32(4) of the Protocol on Tribunal. The SADC Tribunal found that the Respondent of the former case, the Zimbabwean Government, failed to comply with the decision and reported such failure to the SADC Summit in order to ensure appropriate action under the provisions of Art. 32(5) providing: '[i]f the Tribunal established the existence of such failure, it shall report its finding to the Summit for the latter to take appropriate action.' The Tribunal stated that Zimbabwe despite the activation of the process under Art. 32(5) failed to comply with the ruling of the Tribunal. ${ }^{111}$

Since the Republic of Zimbabwe ignored the findings of the SADC Tribunal the case was brought to South African Courts in order to ensure its enforcement and registration.

It was argued that in terms of Art. 3(3) of the Protocol of the SADC Tribunal, the Campbell decision is also enforceable in South Africa. ${ }^{912}$ Furthermore, Art. 32(3) of the Protocol stipulates that the decisions of the SADC Tribunal are binding to the involved parties and are further enforceable within the territories of the concerned States. Thus, the applicant argued that under this provision all SADC Member States are responsible for the enforcement of the decisions by the Tribunal and the SADC Tribunal decision was successfully registered with the High Court of Gauteng in 2009.

Zimbabwe however stated that it would not be bound by the judgment of the High Court of Gauteng since it is rewarded state immunity und der the provisions of sections 2 of the South African Foreign Immunities Act (FSIA). Section 2 provides that 'a foreign State shall be immune from the jurisdiction of the courts of the Republic except as provided in this Act or in any proclamation issued thereunder'. Section 3 of this Act, however, states that immunity is not in power if the respective State waived the latter, which in this case was done through the signature of the SADC Treaty. ${ }^{913}$

Despite the assertion by Zimbabwe, the High Court of Gauteng made a service order against Zimbabwe and attached property in form of real estate of the Zimbabwean Government in accordance with Art. 14(3) of FSIA. ${ }^{114}$ Finally, after the appeal of the defendant, the decision of the High Court was approved by the Supreme Court of Appeal (SCA) ${ }^{915}$ and the Constitutional Court of South Africa. ${ }^{916}$

\footnotetext{
911 Ibid., para 1.

912 Government of the Republic of Zimbabwe v. Fick (2012) ZASCA 122 (SCA Judgment), Judgment of 27 June 2013.

913 Ibid., paras 24.

914 M. Swart, 'Extending the Life of the SADC Tribunal Judicial Decisions', 38 S Afr YB Int'l L (2013), 253.

915 See: Government of the Republic of Zimbabwe v. Fick (2012) ZASCA 122, Judgment of 27 September 2012.

916 See: Fick and Others v. the Government of Zimbabwe, Constitutional Court of South Africa, Case CCT 101/12, para 72.
} 
The Constitutional Court decided common law should be used in order to enforce the jurisdiction on South Africa. The requirements - under common law - for a foreign judgment to be enforced in South Africa inter alia is that the court rendering the judgment was competent to hear the case, that the judgment was final and conclusive, the enforcement is not contrary to public policy and that the judgment 'is not obtained by fraudulent means. ${ }^{917}$ The Constitutional Court stated that common law principles usually only allow the enforcement of judgments of domestic foreign courts. The Constitutional Court finally argued that SADC Tribunal judgments even though South Africa not being party to the dispute could be enforced within South Africa since due to obligations in international law. ${ }^{918}$ By developing the requirements of the enforcement of a foreign jurisdiction to include the jurisdiction of the SADC Tribunal, the Constitutional Court found, that all requirements for enforcement were met. ${ }^{919}$

The decision of the South African Constitutional Court is of great importance since it also allows the enforcement of judgments of other subregional Courts in South Africa. Thus, the Fick decision extends the life of the SADC Tribunal decisions since they can be enforced in South Africa. ${ }^{920}$

\section{b) Tembani v. Republic of Zimbabwe}

Besides the Campbell case, the Tembani v. Republic of Zimbabwe ${ }^{921}$ case also involved the issues of the land reform of the Republic of Zimbabwe.

The case of Luke Munyandu Tembani v. Republic of Zimbabwe involved property of a Zimbabwean farmer, which was auctioned due to an enforcement clause in the loan agreement of the owner. The clause was based on the Agricultural Finance Corporation Act of Zimbabwe and the property was auctioned because of outstanding payments. ${ }^{922}$

The clause in the contract referred to Section 38(2) of the Act stating that:

Should the borrower commit or be in breach of any of the terms or conditions of this agreements the Corporation specifically stipulates as provided in section 40 of the Act, that it shall have the right terms of that section of the Act, after demand by registers letter addressed to the borrower at his last known address or to the address given by him in his application for this loan, and without recourse to a court of law, to enter upon the property hypothe-

\footnotetext{
917 T. Chidede, Legal Protection of Foreign Direct Investment. A Critical Assessment (2016), 132.

918 Government of the Republic of Zimbabwe v. Fick and Others, Constitutional Court, [2013] ZACC 22, 2013 (5) SA 325 (CC), paras 54-70.

919 Swart (2013) 259.

920 Ibid.

921 Luke Munyandu Tembani v. Republic of Zimbabwe, (SADC (T) 07/2008) [2009] SADCT 3 (14 August 2009).

922 Viljoen (2007), 493.
} 
cated and to take possession thereof and sell and dispose of the same in whole or in part as the Corporation may determine, always in terms of and subject to the provisions of the Act. ${ }^{923}$

The Act itself is based on Art. 16(7)(d) of the Zimbabwean Constitution, which is an exception to the principle of prohibition of expropriation of Art. 16(1) of the Constitution. ${ }^{924}$

Art. 16(7)(b) states that:

Nothing contained or done under the authority of any law shall be held to be in contravention of sub-section (1) to the extent that the law in question makes provision for the acquisition of any property or any interest or right therein in any of the following cases

(...)

d) as an incident of a contract, including a lease or mortgage, which has been agreed upon between the parties to the contract, or of a title deed to land fixed at the time of the grant or transfer thereof and any other time with the consent of the owner of the land.

The applicant then claimed before the High Court of Zimbabwe, stating that the surcharge of the auction took place below price due to missing advertisement. Further, he was questioning the constitutionality of section 38(2) of the Act.

However, the judge of the High Court confirmed the constitutionality of the Act and referred to earlier decisions issued by the Supreme Court. ${ }^{925}$

After the decision issued by the Zimbabwean High Court, the applicant asks the SADC Tribunal to determine the constitutionality. Consequently, the SADC Tribunal decided that it is competent and that the claim before the Court by the applicant is permissible, Art. 15(2) of the Protocol on the Tribunal. The Tribunal than stated, that the exclusion of fair hearing constitutes a breach of the principles of international law. Further, the Court found a breach of the rules of natural justice ${ }^{926}$ since the applicant did not have the opportunity to issue a claim before the Supreme Court of Zimbabwe. The Tribunal pointed out that both, section 38(2) of the Act and Art. 16(7)(d) of the Constitution are not in consistency with Art. 4(c) and 6(1) of the SADC Treaty. ${ }^{927}$

923 Luke Munyandu Tembani v. Republic of Zimbabwe (SADC (T) 07/2008) [2009] SADCT 3 (14 August 2009), 2.

924 Ibid., 4.

925 Ibid., 7.

926 This principle has its origin in the English common law. The principle includes two different principles. The first one says that no one should be judge in its own things (nemo iudex in causa sua). It further states that both parties belonging to a dispute dispose of a claim on fair hearing (audi alteram partem); See: T. Allan, 'Procedural Fairness and the Duty of Respect', 18 Oxford Journal of Legal Studies 3 (1998), 497-515.

927 Luke Munyandu Tembani v. Republic of Zimbabwe, Application No.: (SADC (T) 07/2008) [2009] SADCT 3, Judgment of 14 August 2009, 9. 
Finally, the Court determined the auction of the applicants' property to be unlawful and void. Thus, the property remained in ownership of the applicant. ${ }^{928}$

The government of Zimbabwe, however, did not comply with the findings of the SADC Tribunal. Thus, the farmer and his family were forced to leave the farm and were not allowed to take any personal equipment. ${ }^{929}$

In this judgment, it is noticeable that the SADC Tribunal refers to decisions issued by the South African Superior Court on similar matters. The Tribunal appropriated a large proportion of the legal assessment of the South African Court and then finally stated that the Zimbabwean rules violate the Treaty of the SADC Community. While referring to South African national law, the Tribunal sets the foundation in matters to the harmonization of the law within the region. ${ }^{930}$

It is thus remarkable that the SADC Tribunal, similar to other subregional courts within the continent makes use of international treaties, such as the VCLT. Finally, the SADC Tribunal tries to continue the Anglo-American tradition of law, the common law. ${ }^{931}$

\section{c) Berry Gondo and others v. The Republic of Zimbabwe}

In this case, which again involves human rights violations, the applicants were victims of violence inflicted on them by the National Police and Army of Zimbabwe. Consequently, the applicants demanded remedies in national courts of Zimbabwe but finally were successful with their claims. However, the respondent did not comply with the orders issued by the competent court and thus, the applicants did not have the opportunity to enforce the orders of the involved court due to section 5(2) of the State Liability Act, which prevents the execution of judgments against property of the respondent.

Hence, the applicants argued before the SADC Tribunal, that the above-mentioned section is not consistent with the provisions of Art. 4(c) and Art. 6(1) of the SADC Treaty since the applicant was not able to enforce its remedies. Thus, the applicant argues that the failure of the availability of effective remedies constitutes a breach of human rights principles detailed in the above-mentioned rules. ${ }^{932}$

The Tribunal found, that where the State does not provide for effective remedies, it is in breach of the provisions of the above-mentioned sections of the SADC Treaty. The Court found that the right on effective remedies is a fundamental right being guaranteed through the principle of rule of law. ${ }^{933}$ In terms of the non-dis-

\footnotetext{
928 Ibid., 9 et seq.

929 Scharfenberg (2014), 111-122.

930 'Black Farmer Falls on Hard Times Sunday Times South Africa', Sunday Times (21 May 2011), available at: https://www.timeslive.co.za/sunday-times/lifestyle/2011-05-21-black-farmer-fallson-hard-times/ (last visited: 29 June 2017).

931 Scharfenberg (2014), 121.

932 Ibid.

933 See: Afadameh-Adeyemi (2011).
} 
criminatory provisions of Art. 26 of the International Covenant on Civil and Political Rights (ICCPR) the Tribunal concluded that section 5(2) of the State Liability Act was discriminatory. The Tribunal reasoned the discriminatory effect because 'it treated judgement creditors who had obtained judgements against the responded differently from creditors who had obtained judgement against private litigants. ${ }^{934}$ Moreover, the Tribunal took into consideration that the Constitutional Court of South Africa declared a similar provision to be unconstitutional. In addition, the Tribunal found that the compensation needs to be revalorized in accordance with Art. 12(h) of the SADC Charter of Fundamental Social Rights stating that ' $[\mathrm{w}]$ orkers have the right to services, that provide for the prevention, recognition, detection and compensation work related illness or injury, including emergency care, with rehabilitation and reasonable job security after injury and adequate inflation-adjusted compensation', since the currency of Zimbabwe depreciated over the years.

\section{d) The United Republic of Tanzania v. Cimexpan (Mauritius) Ltd., Cimexpan (Zanzibar) Ltf \& Ajaye Jogoo}

Besides the claims of individuals involving human rights, the Tribunal is also competent to hear disputes involving SADC Member States. ${ }^{935}$ Furthermore the Protocol permits the Tribunal to develop its own jurisprudence. ${ }^{936}$ One case involving two different SADC Member States is that of United Republic of Tanzania v. Cimexpan (Mauritius) Ltd., Cimexpan (Zanzibar) Ltf \& Ajaye Jogoo ${ }^{937}$.

The main application arose from a memorandum of understanding which had been entered into by the Government of Mauritius and the Government of Zanzibar. Thus, the third respondent, being the Director of Cimexpan (Mauritius) Ltd. (the first respondent), started some investments in Zanzibar and thus signed a concession contract with Zanzibar's Government through a joint venture. As consequence, a new company, Cimexpan (Zanzibar) Ltd. (the second respondent) was established. In a letter issued on 21 September 2003, the Government of Zanzibar informed the Director of Cimexpan (Mauritius) Ltd., that the contract had been terminated. Consequently, the applicant deported the third respondent. ${ }^{938}$

\footnotetext{
934 See: Barry Gongo \& 8 Others v. The Republic of Zimbabwe, 05/2008, Judgment of 9 December 2010, para 4.

935 Chitimira \& Mokone (2016), 23.

936 See: Art. 21(b) of the Protocol on Tribunal: It is important for the Tribunal to develop its own jurisprudence because it has no predecessor to refer to its decisions and accordingly must wade into unchartered waters.

937 United Republic of Tanzania v. Ciexpan (Mauritius) Ltd., Cimexpan Zanzibar Ltd. \& Ajaye Jogoo, SADC (T) 01/2009 (2011), Judgment of 6 June 2010.

938 Scharfenberg (2014), 130 et seq.
} 
The ruling of the Tribunal then deals with three preliminary objections that have been raised by the Republic of Tanzania with reference to the main case being instituted by the respondents in order to have a deportation order issued against the third respondent rescinded.

The applicant argued that the Tribunal does not have jurisdiction on this case since the respondents did not exhaust local remedies.

The Tribunal found that it did not have jurisdiction over this case and acknowledged thus the principle of exhaustion of local remedies. It stated that the principle is not unique to the Protocol but is a 'common feature of regional and international conventions. ${ }^{9} 39$

However, the respondent argued that he was not able to make use of the Tanzanian legal remedies set out by section 14(6) of the Tanzanian Immigration Act since he was not allowed to enter Tanzania due to the deportation. ${ }^{940}$

The Tribunal than argued that the respondent at least would have had the opportunity to make use of Zanzibar domestic courts and thus he did not exhaust national remedies. ${ }^{941}$

Furthermore, the Tribunal argued that it is not able to determine any abuse and torture. After the reference to the Resolution 40/144 in conjunction with the UN Charter on human rights, ${ }^{942}$ the Tribunal stated that it is not able to determine any possible violation of the principles since the respondent did not introduce any evidence. ${ }^{943}$

The decision shows that the SADC Tribunal is not willing to justify its competence at all costs. However, it also shows that the Tribunal is fully intended to punish any violation of human rights committed by a SADC Member State. ${ }^{944}$

Neither the SADC Treaty nor the SADC Protocol makes an explicit reference to the jurisdiction relating to human rights. ${ }^{945}$ Nevertheless, some provisions of the SADC Treaty refer to human rights principles. For instance, the Preamble of the SADC Treaty refers to human rights asserting: 'MINDFUL of the need to involve the people of the Region central in the process of development and integration, particularly through the guarantee of democratic rights, observance of human rights and the rule of law.' Furthermore, Art. 5(1) and Art. 6 (as it was amended in 2001)

\footnotetext{
939 A. Olufolahan, 'Revisiting locus standi and the grounds for jurisdiction of the SADC Tribunal in United Republic of Tanzania v. Ciexpan (Mauritius) Ltd., Cimexpan Zanzibar Ltd. \& Ajaye Jogoo, SADC (T) 01/2009', 1 SADC Law Journal (2011), 207.

940 Ibid.

941 See: United Republic of Tanzania v. CIMEXPAN (Mauritius) Ltd., CIMEXPAN (Zanzibar) Ltd. and Ajaye Jogoo, SADC (T) 01/2009, Judgment of 6 June 2010, 5 et seq.

942 The Court cited the minimum standards to be the following: 'these principles include non-discrimination on grounds of race, the prohibition of torture and inhuman or degrading treatment or punishment, and the right for a fair trial", see ibid., 7 .

943 Scharfenberg (2014), 134.

944 See: United Republic of Tanzania v. CIMEXPAN (Mauritius) Ltd., CIMEXPAN (Zanzibar) Ltd. and Ajaye Jogoo, 7.

945 Chitimira \& Mokone (2016), 23.
} 
refer to human rights principles inter alia stating that 'SADC Member States shall not discriminate against any person on grounds of gender, religion, political views, race, ethnic origin, culture, ill health, disability or such ground as may be determined by the Summit. ${ }^{.946}$

In the findings of the Campbell case, the Tribunal considered itself obliged to exercise jurisdiction in human rights matters since it had to follow Art. 4(c) of the SADC Treaty. ${ }^{947}$ The findings convinced some lawyers and human rights activists that the SADC Tribunal could be a 'potentially viable international forum for vindicating alleged violations of human rights within the territories of SADC Member States. ${ }^{9}{ }^{948}$ Thus the SADC Tribunal became a symbol of hope for the respect for human rights in States that do not really honor them, since access for individuals on the regional level to the African Court on Human and Peoples' Rights is very limited. ${ }^{949}$ Many academics believed that the adoption of those instruments, which honor the protection of human rights, is a significant development since it promoted the acceptance of human rights by the African governments of SADC Member States. ${ }^{950}$ Nevertheless, the Tribunal's main focus remained the protection of regional peace and security and the integration of regional economies. ${ }^{951}$

Similar to other regional courts, for instance, the Tribunal of the East African Community (EAC), the Tribunal gives itself the competence to hear cases on human rights matters. For instance, the competence to hear cases involving human rights of the EAC is dependent from the coming into force of a Protocol. ${ }^{952}$

Additionally, similar to most other regional courts within Africa - such as the COMESA Tribunal - the SADC Tribunal (until its suspension in 2010, as discussed below) decided on only one case involving customs duties. Furthermore, none of the cases decided by the SADC Tribunal involved any intra-state complaints but rather were based on claims of individuals seeking human rights protection. ${ }^{953}$

\subsubsection{The Suspension and establishment of a new SADC Tribunal Protocol}

As a result of its jurisdiction - especially because of the attempt to enforce the judgment of the Campbell case - the SADC Tribunal was suspended with a new Protocol to the SADC Tribunal being subsequently adopted.

\footnotetext{
946 S. Meckler, 'A Human Rights Monster that Devoured No One: The Far-Reaching Impact of Dismantling the SADC Tribunal Notes', 48 NYU J Int'l L \& Pol (2015), 1007, 1011.

947 Nkhata (2012), 94.

948 S. T. Ebobrah, 'Tackling threats to the existence of the SADC Tribunal: A Critique of perilously ambiguous provisions in the SADC Treaty and the Protocol of the SADC Tribunal' 4 Malawi Law Journal (2010), 199, 200.

949 Ibid.

950 Nathan (2013), 870.

951 Nkhata (2012), 93.

952 Ebobrah (2010), 200.

953 Scharfenberg (2014), 145.
} 


\section{a) The suspension of the Tribunal - an endorsement of Zimbabwe}

The SADC Tribunal is still not operational at present following its suspension at the 2010 Windhoek Summit. ${ }^{954}$ The SADC Summit declared in 2011 that the Tribunal had no mandate to adopt any new cases, even if they were in no way related to the so-called Campbell case. ${ }^{955}$ Many lawyers' associations and human rights groups seriously criticized this decision. ${ }^{956}$ Furthermore, the Summit failed to renew the tenure of the Tribunal judges, rendering the Tribunal ineligible to hear any further cases, since its composition was not in accordance with the requirements of Art. 3 of the SADC Tribunal Protocol. ${ }^{957}$ Consequently, the suspension of the Tribunal shows the poor level of democracy and good governance to potential investors within the SADC region..$^{958}$

In 2011 independent reviewers and the SADC Committee of Ministers of Justice/Attorneys General meeting proposed that 'the reappointment and replacement of the members of the SADC Tribunal be finalized. ${ }^{.959}$ Nevertheless, the Summit ignored the various findings of the meeting and neither reappointed the sitting judges nor called for the election of new judges. ${ }^{960}$

In 2012 the SADC Summit pointed out that a new Protocol should be negotiated and should contain amendments with regard to its jurisdiction to the effect that the new Tribunal's jurisdiction shall be limited to disputes between SADC Member States. ${ }^{91}$ Chief Justice Pillay stated in this context that 'SADC gave off all the right buzz words, you know, 'democracy, rule of law, human rights - and then they got the shock of their lives when we said these principles are not only aspirational but also justiciable and enforceable and we showed that we meant what we said.962

Individuals may however still have the possibility to claim before other international courts within Africa. For instance, most of the SADC Member States are also party to the Common Market of Eastern and Southern Africa (COMESA), most upcoming trade disputes that would have fell under the jurisdiction of the SADC Tribunal, may still fall under the jurisdiction of the COMESA Tribunal. As Tanzania is the only State that also belongs to the East African Community, a trade dispute that falls under the jurisdiction of both the Court of the East African Com-

\footnotetext{
954 Saurombe (2011), 397.

955 Ibid., 395.

956 Ebobrah (2010), 202.

957 Saurombe (2012), 467.

958 Nathan (2013), 871.

959 Saurombe (2011), 397.

960 Human Rights Watch, Regional Court's Future Hangs in Balance, available at: https://www.hrw. org/sites/default/files/related_material/SADC\%20tribunal_QA_Final\%20Post\%20HRWPress. pdf, (last visited: 6 August 2016).

961 Sarkin (2016), 221.

962 Ibid.
} 
munity and SADC Tribunal simultaneously, may not arise. ${ }^{963}$ Rwanda wanted to join SADC as well but was not successful. ${ }^{964}$ Furthermore, individuals may submit human rights related cases to the African Commission, which may in turn forward such cases to the African Court of Human an Peoples' Rights, which before the suspension of the SADC Tribunal and the limitation of the competences of the new Tribunal would have had fallen under the jurisdiction of the old SADC Tribunal. Apart from the level of the African Union, other international forums, such the International Criminal Court exist, in order to resolve disputes that are submitted by individuals. Many scholars have so far, criticized the issue of overlapping jurisdiction. ${ }^{965} 966$ The use of those different forums may - in case of SADC citizens - be advantageous for the members of SADC, since the individuals have the opportunity to use the African Commission or the COMESA Court in case of human rights violations. The SADC Tribunal has been severely dented 'to the extent that Member States may not even consider taking their cases there in the first place. ${ }^{967}$

It was, naturally, the Government of Zimbabwe that primarily pushed for the dissolution of the SADC Tribunal. As a result of the numerous findings of the SADC Tribunal that affected Zimbabwe, the Zimbabwean government tried to find support within the SADC region to stop the Tribunal's work. ${ }^{968}$ In this context Cowell stated:

What is particularly alarming about the SADC Tribunal saga is how the Zimbabwean Government has managed to create a form of regional consensus about weakening the rule of law among SADC governments. SADC's commitment to supporting the rule of law has been seriously undermined by the decision to terminate the Tribunal's human rights jurisdiction. ${ }^{969}$

Thus, the suspension of the Tribunal is the result of successful lobbying of the government of Zimbabwe. ${ }^{970}$ The discussion on the suspension of the SADC Tribunal showed that there was a 'common commitment to state solidarity and regime protection.' $^{971}$

963 N. Fritz, 'Quiet death of an important SADC institution', Mail\&Guardian (29 August 2014), available at: https://mg.co.za/article/2014-08-29-quiet-death-of-an-important-sadc-institution, (last visited: 17 June 2016).

964 The application of Rwanda to join SADC was unsuccessful while the application of Madagascar was successful at this point of time, see: J. Konopo, 'Madagascar joins SADC while Rwanda fails' (17 August 2015), available at: https://www.mmegi.bw/2005/August/Wednesday17/ 426374890200.html, (last visited: 6 September 2018).

965 Saurombe (2011), 401 et seq.

966 Gathii (2011) 297.

967 Saurombe (2011), 403.

968 Alter et al (2016), 308.

969 F. Cowell, 'The Death of the Southern African Development Community Tribunal's Human Rights Jurisdiction', 13 Hum Rts L Rev (2013), 153, 220.

970 Sarkin (2016), 218.

971 Cowell (2013), 153. 
The decision of the Summit on the suspension of the Tribunal had to be taken in consensus. This raises the question of how consensus was reached, thereby supporting the Zimbabwean court ruling that SADC Tribunal findings did not apply in their country: Firstly, the post-colonial redistribution of land and thereby also the land reforms were still at the top of political agendas in countries such as South Africa, Zimbabwe and Namibia. If the Tribunal's decision had been enforced, it would probably have been 'felt beyond the borders of Zimbabwe', creating serious administrative and practical consequences. Since the mentioned countries used similar programs to address similar colonial injustices, they supported Zimbabwe. ${ }^{972}$

Furthermore, countries like Angola, Swaziland and the Democratic Republic of Congo have been in favor of the Tribunal's suspension, since they featured at a very low level on human rights protection. ${ }^{973}$

\section{b) The creation of the new Protocol on the Tribunal}

After the Tribunal got suspended, the competences of the Tribunal have been reviewed according to the will of the Zimbabwean government. ${ }^{974}$ The Summit finally decided to set up a new Tribunal through the adoption of a new Protocol.

The new Protocol on the SADC Tribunal was adopted at the meeting of Heads of States and Governments on 18 August 2014, but only 9 out of 15 Member States signed the Protocol so far. Countries yet to sign include Angola, Botswana, Madagascar, Mauritius, Seychelles and Swaziland. ${ }^{975}$

According to Art. 53 of the Protocol, it will come into force 30 days after the ratification by at least two-thirds of Member States - currently 10 out of 15 States. In addition to that, the Protocol stipulates that only a State that has signed the Protocol is able to ratify the Protocol. ${ }^{976}$ Since only 9 out of 15 Member States have signed the Protocol yet, one more SADC Member State still needs to sign the Protocol before it can come into force. Until today, no State has taken any steps to ratify the new Protocol and even Zimbabwe, that badly wanted the dissolution of the old Tribunal, is still to ratify it. ${ }^{977}$

\footnotetext{
972 Ibid.

973 M. Hulse \& A. van der Vleuten, 'Agent Run Amuck: The SADC Tribunal and Governance Rollback', in T. A. Börzel \& V. van Hüllen (eds), Governance Transfer by Regional Organisations (2015), 84, 96.

974 Mapuva \& Muyengwa-Mapuva (2014), 32.

975 G. Erasmus, 'The New Protocol for the SADC Tribunal: Jurisdictional Changes and Implications for the SADC Community Law', TRALAC Working Paper (2015), 1.

976 The New Protocol on the SADC Tribunal, available at: http://www.mikecampbellfoundationresources.com/page/new-protocol-on-sadc-tribunal, (last visited: 6 August 2016).

977 N. Chenga, 'Southern Africa: SADC Tribunal Downgraded' (27 August 2015), available at: http://allafrica.com/stories/201508270542.html, (last visited: 20 June 2016).
} 
The reason for not signing the Protocol could be that those States probably do not want to make any legal errors with regard to the adoption of a new Protocol. ${ }^{978}$ Furthermore, they may also have concerns with regard to the Tribunal's mandate. According to the new protocol, only States will be able to access the new Tribunal. ${ }^{979}$ Art. 33 of the new Protocol advises that the Tribunal will only have jurisdiction over the interpretation of the SADC Treaty and Protocols relating to disputes between Member States. ${ }^{980}$ Thus, citizens of SADC Member States will not be able to receive effective protection in case of human rights violations through the SADC Tribunal. Especially those citizens who do not get effective protection through local courts may experience significant disadvantages. ${ }^{981}$ Consequently, the establishment of a SADC Tribunal with no jurisdiction on human rights leaves many SADC citizens with few or even no remedies for human rights violations. ${ }^{982}$ Moreover, it appears that the previous functions with regard to a preliminary ruling procedure are not of any importance anymore.

Currently, a legal team which is part of the South African Constitutional Court, led by Jeremy Gauntlett SC, challenges the decisions to not guarantee access of individuals before the Court before the African Commission on Human and Peoples' Rights. ${ }^{983}$

The case of the suspension of the SADC Tribunal shows that the strong will of a country - in this case Zimbabwe - is of great importance for the success of regional integration. Furthermore, the circumstances show the weakness of the SADC area concerning the protection of human rights. ${ }^{984}$

\section{c) The decision of the African Commission on Human and Peoples' Rights regarding the suspension of the Tribunal}

In context of the decision by the SADC to renew the Protocol of the SADC Tribunal many attempts were made to review the decision. Many Civil Societies have been active in this regard - but without success. ${ }^{985}$

The complaint ${ }^{986}$ to modify the limited jurisdiction of the SADC Tribunal was submitted by Norman Tjombe, an attorney of Namibia, on behalf of Luke Munyandu Tembani and Benjamin John Freeth. ${ }^{987}$ The respondents in the case were the Mem-

\footnotetext{
978 The New Protocol on the SADC Tribunal.

979 Erasmus (2015), 16.

980 See: Art. 33 of the 2014 Protocol of the SADC Tribunal.

981 Mapuva \& Muyengwa-Mapuva (2014), 32.

982 Chitimira \& Mokone (2016), 24.

983 Swart (2013), 261.

984 Mapuva \& Muyengwa-Mapuva (2014), 32 et seq.

985 Sarkin (2016), 222.

986 Luke Munyandu Tembani and Benjamin John Freeth (represented by Norman Tjombe) v. Angola and Thirteen Others, Communication No. 409/12, Communication of 30 April 2014.

987 Ben Freeth is the son in law of Mike Campbell. In this case, he acted on behalf of the complaints in the Campbell case. see: ibid., para 4.
} 
ber States of the SADC and the Summit of Heads of State as well as the Council of Ministers. The applicants claimed that the suspension of the SADC Tribunal was unlawful and in violation of the African Charter and inter alia the SADC Treaty.

In October 2012, the African Commission ruled that the case would be admissible but then rejected the case in autumn 2013.

The Commission found that it is not competent to hear the Heads of State and Government of the Ministers of the SADC. The Commission further found that it is not competent to hear intergovernmental disputes. ${ }^{988}$ The possible violation of the SADC Treaty was not reviewed by the African Commission. Furthermore, the ACHPR found that Art. 7(1)(a) of the African Charter, which gives the individual the right to access to the Courts, does not oblige the SADC to establish a Court since the provision only applies to the establishment of national courts. However, the African Commission did not use any case law to decide on this fact or did not use any interpretation. The ACHPR further found that Art. 26 of the Charter which guarantees the independence of the courts only applies to national courts. The Commission states that 'even a combined reading of both provisions does not create an obligation to ensure access to the SADC Tribunal.' 989

This conclusion is problematic: The Commission did not give a wider interpretation to the provisions of the Charter in order to guarantee a greater human rights protection to more than 200 million people in southern Africa. Also, the fact that the African Commission until now only had to decide on cases regarding access to national courts does not mean that the Charter automatically excludes a wider interpretation of the Charter.

The complaints stated that the dissolution was not in accordance with Art. 4 of the Charter which states that the SADC members shall act in accordance with the principles of human rights, democracy and the rule of law. The Commission did not raise any of these issues. The Preamble of the African Charter describes justice, equality and freedom, to be of essential meaning for the achievement of the legitimate aspirations of the African People, could lead to the view that such assertion would need to be reviewed.

Furthermore, the Commission could have had reviewed the case under the provisions of Arts. 5, 6 and 8 of the UN Declaration of Basic Principles of Justice for Victims of Crimes and Abuse of Power as well as under the provisions of Art. 8 of the Universal Declaration of Human Rights. Lastly, the Principles and Guidelines on the Rights to a Fair Trial and Legal Assistance in Africa issued by the Commission

\footnotetext{
988 The Commission on Human and Peoples' Rights did state the same in Mohammed El-Nekheily v. OAU, Communication No. 12/88, Communication of 17-26 October 1988. At para 3 it stated: 'Considering that the communication is directed against the OAU which is not a State or Party to the African Charter on Human and Peoples' Rights [the Commission] declares the Communication inadmissible.' 
in 2003 as well as the African Commission's Resolution on the Role of Lawyers and Judges in the Integration of the Charter and the Enhancement of the Commission's Work in National and subregional systems could have been used in this case. ${ }^{90}$

\subsection{Conclusion on the Tribunal of the Southern African Development Community (SADC)}

The suspension of the SADC Tribunal received a lot of criticism with scholars stating inter alia that ' $[\mathrm{b}] \mathrm{y}$ abandoning the court in favor of Harare, it elevated the norms of solidarity and regime protection above the democratic and legal principles espoused in the treaty'991.

In the context of the Campbell decision, the Zimbabwean Government called the SADC Tribunal a 'day-dreamer that was engaged in an exercise in futility'. Some years before, the President of Tanzania, Jakaya Kikwete called the establishment of a SADC Tribunal the creation of 'a monster that would devour us all'. This statement indicates what the SADC leaders were afraid of: a functioning and existing SADC Tribunal. ${ }^{992}$ Particularly, the observation of a possible violation of the principles set out in Art. 4(c), inter alia the principles of democracy, are not welcomed by SADC leaders. Nevertheless, since the authority to control the Tribunals' decisions remained with the Summit, the absolute power, and control of the Tribunal of the SADC leaders was ensured. ${ }^{993}$

The new Protocol, adopted in 2014, prescribed that only Heads of States and Governments in the SADC region are allowed access to the new Tribunal. ${ }^{994}$ The signing Heads of States and Governments pointed out that the content is based on several recommendations. Ironically, the Heads of States and Governments themselves made the 'recommendations'. ${ }^{995}$

\footnotetext{
990 Ibid.

991 Kleis (2016), 103.

992 G. M. Quan, 'Rising against the silencing of the SADC Tribunal: Tanzania' AfricLaw (5 June 2015), available at: https://africlaw.com/2015/06/05/rising-against-the-silencing-of-the-sadctribunal-Tanzania, (last visited: 6 July 2016).

993 Ibid.

994 Fritz (2014).

995 Ibid.
} 
According to the consultative opinion of the Coalition for an Effective SADC Tribunal ${ }^{996}$, the SADC leaders acted illegally when adopting the new Tribunal Protocol, refuses legal persons and individuals' access to the Tribunal. ${ }^{997}$ This action also violated the SADC Treaty, which provides for the 'full involvement of individuals and NGOs in the process of regional integration'.

The SADC leaders did not take the requirements of the SADC Treaty into consideration that provides for the consultation of citizens within SADC in every decision that affects them. However, in the coalition's opinion, the approval of the new Tribunal Protocol affected 'every single citizen and person in the region'. Thus Human Rights Watch insisted that the new Tribunal violated international standards of democracy and rule of law. ${ }^{998}$

In itself the decision of the Summit to suspend the Tribunal was already illegal since neither the SADC Treaty nor the SADC Protocol on the Tribunal allows the Summit to take the dissolution or suspension. ${ }^{999}$

It may take some time until SADC has a working judicial organ. Currently, no SADC member yet ratified the new Protocol. ${ }^{1000}$

Before the closure by the Summit, the previous Tribunal has been the only international judicial body in the SADC region, since private persons, as well as companies, had access to the Tribunal. ${ }^{1001}$ With the decision concerning the land reform in Zimbabwe, that is the Campbell case, the judges made a big step towards an effective human rights protection through the SADC Tribunal, which brought hope to the region.

However, instead of building an SADC Tribunal that would be respected internationally, supposed to be comprised by leading judges of the region, the Summit approved the resolution to establish a 'Southern African Development Community Administrative Tribunal'. Since most of the cases considered by the original Tribunal have been from Zimbabwe, it seems the person currently benefiting most from the suspension of SADC Tribunal is the former Zimbabwean President Robert Mugabe. ${ }^{1002}$ With regard to South Africa, the Law Society of South Africa submitted a

$\overline{996}$ Coalition members are independent human rights, faith-based and legal organisations from 19 African countries, including Tanzania, South Africa, Swaziland, Zimbabwe, Mozambique, Angola, Lesotho, Malawi and the Seychelles, in addition to the International Commission of Jurists (ICJ); see: Official Website of the Law Society South Africa, SADC Tribunal Matter: available at: http:// www.lssa.org.za/our-initiatives/advocacy/sadc-tribunal-matter, (last visited: 9 September 2018). Calls for SADC leaders to reinstate regional tribunal, available at: http://citizen.co.za/530047/ calls-for-sadc-leaders-to-reinstate-regional-tribunal/., (last visited: 8 June 2016).

998 Chenga (2015).

999 Saurombe (2012), 471.

${ }^{1000}$ Erasmus (2015), 1.

1001 Jonas (2013), 296.

1002 R. Ndlovu, 'Sadc Tribunal back with mandate reduced to interstate cases', BusinessDay (20 August 2014), available at: http://www.bdlive.co.za/africa/africannews/2014/08/20/sadctribunal-back-with-mandate-reduced-to-interstate-cases, (last visited: 22 June 2016). 
case $^{1003}$ to the High Court in Pretoria declaring the resolution of the former President of South Africa - Jacob Zuma - to suspend the SADC Tribunal to be unlawful. The High Court found that Zuma, acted unlawfully and unconstitutionally as the Parliament of South African did not express its consent to this step. ${ }^{1004}$

In conclusion, the level of democracy in terms of independence of the judiciary is currently neither high nor improving. Due to the suspension of the Tribunal, the process of democratization took a step back. Especially the decision by the African Commission considering the dissolution of the SADC Tribunal to be in conflict with the African Charter or its Guidelines would have been leading greater attention on the issue of the dissolution of the SADC Tribunal. The attention on the issue continent-wide may have led to the decision not to limit the access to the Tribunal due to the strong opposition for the governments that were involved in the decision. The decision of the Commission does not promote the protection of human rights but rather supports the incomprehensible decision of the Heads of State and Government. ${ }^{1005}$

\subsection{The Parliamentary Forum of the Southern African Development Community}

The Parliamentary Forum of the Southern African Development Community (SADC-PF) appears to be positioned to be the legislative institution of the SADC and may have an impact on the protection of the rule of law. However, in contrast to some other regional integration agreements, the SADC Treaty does not refer at all to a possible establishment of a regional parliament within the SADC region.

\subsubsection{Introduction}

The SADC-PF was established in 1997 in accordance with Art. 9 (2) of the SADC Treaty. The SADC-PF is a regional inter-parliamentary consultative body composed of 14 National Parliaments, aiming to represent over 3,500 parliamentarians in the SADC region. ${ }^{1006}$

1003 See: Law Society of South Africa and Others v. President of the Republic of South Africa and Others (20382/2015) [2018] ZAGPPHC 4; [2018] 2 All SA 806 (GP); 2018 (6) BCLR 695 (GP) (1 March 2018).

1004 J. Maromo, 'Zuma's role in dismantling SADC Tribunal slammed by court', IOL (1 March 2018), available at: https:/www.iol.co.za/news/south-africa/gauteng/zumas-role-in-dismantlingsadc-tribunal-slammed-by-court-13543070, (last visited: 24 August 2018).

1005 Peter-Berries (2010), 148.

1006 SADC Parliamentary Forum, Election Observation Mission Report for the 2012 Angola General Elections, 3. 
The current member parliaments of the SADC-PF are Angola, Botswana, Lesotho, Malawi, Mauritius, Mozambique, Namibia, South Africa, Seychelles, Swaziland, Tanzania and Zimbabwe. ${ }^{1007}$ The current headquarters of the SADC-PF is Windhoek, Namibia. ${ }^{1008}$

The vision of the SADC-PF is to be 'a delivery-focused, people-centered institution that accelerates and promotes parliamentary participation in regional decision-making for the benefit of SADC citizens.'

While the SADC-PF was inaugurated, the Summit in its speech expressed that one of the main goals of the Parliamentary Forum should be 'to constitute a Parliamentary Consultative Assembly, the ultimate goal being the establishment of a Regional Parliamentary Framework for dialogue on issues of regional interest and concern.'

\subsubsection{Legal status of the SADC Parliamentary Forum}

The SADC-PF was created with the objective to be an independent institution within the SADC structure. However, at this point in time, the Parliamentary Forum is still not recognized as an official institution of the SADC. It is however linked to the SADC while claiming to be a body 'in its own right. ${ }^{\text {'009 }}$ Furthermore, the SADC structure arrangements currently do not stipulate any role for parliaments in policy formulation. Even in the extensive amendments of the SADC Treaty in 2002, a legislative institution within the SADC framework was not intended. ${ }^{1010}$

In a labor dispute ${ }^{1011}$ between the SADC-PF and an employee, heard by the SADC Tribunal, the SADC-PF thus argued that the SADC Tribunal does not have any jurisdiction over the SADC-PF, since the SADC-PF is not a SADC institution. The SADC Tribunal refuted these arguments and found that it does have jurisdiction over the SADC-PF as a SADC institution. ${ }^{1012}$ Thus, in time of hearing, the SADC-PF did not consider itself to be a SADC institution. The judgment of the SADC Tribunal thus might have given a new push towards strengthening of the relation of SADC and the SADC-PF.

\footnotetext{
1007 Ibid.

1008 C. Barasa, 'Case made for transformation of SADC PF into regional parliament' DailyNews, available at: http://dailynews.co.tz/index.php/features/49873-proposal-for-sadc-parliamentary-forum, (last visited: 15 June 2016).

1009 Record of SADC Summit of Heads of State and Government held in Blantyre, Republic of Malawi 8 September 1997.

1010 Musavengana (2011).

1011 See: Bookie Monica Kethusegile-Juru v. the Southern African Development Community Parliamentary Forum, SADC (T) 02/2009, Judgment of 11 June 2010.

1012 Musavengana (2011), 52; see also: ibid., para 6
} 


\subsubsection{The composition of the SADC Parliamentary Forum}

The Parliamentary Forum consists of parliamentarians from national parliaments, who have the duty to represent more than 3,500 parliamentarians all over the SADC region. ${ }^{1013}$ Normally, the representatives of the national parliaments are elected for a period of five years unless they are inter alia replaced by their national parliaments. ${ }^{1014}$

Each national parliament has the possibility to elect their respective four representatives. ${ }^{1015}$ While electing the representatives of each SADC Member State, each national Parliament has to ensure an equitable representation of women and of the political parties represented in the national Parliament, to comply with the requirements of the SADC-PF Constitution. ${ }^{1016}$

The main objective of the Parliament is the improvement of regional integration within the SADC region while promoting parliamentary involvement. ${ }^{1017}$ The Parliamentary Forum is supposed to act as a link between national parliaments and therefore is an important institution within the SADC framework. ${ }^{1018}$ According to Art. 6 of the Constitution of the SADC-PF, it 'shall consist of the presiding officers and three representatives elected to the SADC Parliamentary Forum from each national parliament.'

\subsubsection{Internal Structure of the SADC Parliamentary Forum}

The SADC Parliamentary Forum (SADC-PF) features three distinctive organs within its internal structure: The Plenary Assembly, the Executive Committee and the Standing Committees.

The Plenary Assembly, which represents the national parliaments on SADC lev$\mathrm{el}$, is the highest policy-making and deliberative organ of the SADC-PF. ${ }^{1019}$ The Assembly meets twice a year in order to hold debates on policy decisions and to make recommendations which are forwarded to the SADC Summit of Heads of States and Governments with regard to issues which affect the SADC region. The location of Plenary Assembly meetings is to be determined on a rotational basis. ${ }^{1020}$

According to the SADC-PF Constitution, the Plenary Assembly shall consist of Presiding Officers and the Representatives of the SADC Parliamentary Forum. ${ }^{1021}$ Furthermore, the Executive Committee of the SADC-PF is responsible for the man-

\footnotetext{
1013 Musavengana (2011), 17.

1014 SADC Parliamentary Forum, Strategic Plan 2006-2010, 31; See also: Art. 6(4) of the 1999 SADC Parliamentary Forum Constitution.

1015 See: Art. 6(3) of the 1999 Constitution of the Parliamentary Forum.

1016 SADC Parliamentary Forum, Strategic Plan 2006-2010, 31; See also: Art. 6 (3) of the 1999 SADC Parliamentary Forum Constitution.

1017 See: Art. 5(1) of the 1999 SADC Parliamentary Forum Constitution.

1018 See. Art. 5(1)(2) of the 1999 SADC Parliamentary Forum Constitution.

1019 See: Art. 8 (3)(a) of the 1999 SADC Parliamentary Forum Constitution.

1020 Rule 22 of the SADC-PF Rules of Procedure.

1021 See: Art. 8(1) of the 1999 Constitution of the SADC Parliamentary Forum.
} 
agement of the various affairs of the SADC-PF, and gives direction to the Secretariat while ensuring that decisions of the Plenary Assembly are implemented. ${ }^{1022}$ In addition to that, the Executive Committee is accountable to the Plenary Assembly. ${ }^{1023}$

The Executive Committee is composed of six Speakers of the respective national parliaments of its Member States and seven other representatives that are elected by the Plenary Assembly every two years. ${ }^{1024}$ Last but not least, the Executive Assembly appoints a Secretary General, who is the Chief Executive of the SADC-PF, responsible for coordinating the forum's programs. ${ }^{1025}$ The Executive Committee meets twice a year for 'the transaction of business' but may have additional meetings if deemed necessary. ${ }^{1026}$

The Executive Forum's duties are inter alia the preparation of an annual budget that is presented to the Plenary Assembly for approval, the preparation of annual reports, including the SADC-PF meeting reports, and the presentation of draft programs concerning the activities of the SADC-PF. ${ }^{1027}$

Five Standing Committees were set up to strengthen the implementation capacity of SADC. Their objective is to involve parliamentarians in the activities of SADC. ${ }^{1028}$ The SADC-PF Constitution confers on the Plenary Assembly the power to transfer any of its powers as it may see fit, to the Standing Committees. ${ }^{1029}$ According to the SADC-PF Constitution, the Plenary Assembly 'shall seek to ensure the equitable representation of the parliaments that are represented in the SADC Parliamentary Forum. ${ }^{1030}$

\subsubsection{Aims and powers of the SADC Parliamentary Forum}

The forum was inter alia set up in order to promote economic co-operation as well as matters with regard to human rights, the rule of law and the concept of democracy. ${ }^{1031}$

According to the communique of the SADC Summit meeting in 1997, where the SADC Parliamentary Forum was established, the '[...] the main objective of the SADC-PF is to constitute a parliamentary framework for dialogue on issues of regional interest and concern. ${ }^{\prime} 1032$ The forum defined its main vision as follows:

\footnotetext{
1022 See: Art. 9(1) of the 1999 Constitution of the SADC Parliamentary Forum.

1023 See: Art. 9(3) of the 1999 Constitution of the SADC Parliamentary Forum.

1024 See: Art. 9(2)(a) of the 1999 Constitution of the SADC Parliamentary Forum.

1025 See: Art. 10(2) of the 1999 Constitution of the SADC Parliamentary Forum.

1026 See: Art. 9(3) of the 1999 Constitution of the SADC Parliamentary Forum.

1027 See: Art. 9(5)(i)(ii)(iii) of the 1999 Constitution of the SADC Parliamentary Forum.

1028 See: Art. 11 of the 1999 Constitution of the SADC Parliamentary Forum.

1029 Ibid.

1030 Ibid.

1031 Scharfenberg (2014), 54.

1032 See: Southern African Development Community; Record of SADC Summit held in Blantyre, Republic of Malawi 8 September 1997.
} 
To achieve comprehensive, effective and sustainable regional integration and prosperity based on democratic governance and freedom in the SADC region; and to bring about a united SADC family conscious of its common identity and sense of dignity. ${ }^{1033}$

In his speech at the meeting, Dr. Mosé P. Tjitendero, the Speaker of the National Assembly of Namibia, stressed the promotion of the principles of human rights and democracy in the SADC region, and the familiarization of the SADC citizens with the objectives and aims of the SADC. ${ }^{1034}$

In the Strategic Plan towards the Establishment of a SADC Parliament, the current vision of the SADC-PF is stated 'to be a Regional Parliament that reflects and represents the collective voice and aspirations of national Parliaments and SADC citizens. ${ }^{1035}$ Nevertheless, the mandate of the SADC-PF is still limited, '[...] due to its status and discussions to transform it into a fully-fledged parliament." ${ }^{\text {'036 }}$

Moreover, the SADC-PF Constitution lists the aims and objectives of the SADC-PF. Art. 5 of the SADC-PF Constitution inter alia states that the SADC-PF shall

- facilitate the effective implementation of SADC policies and projects

- familiarize the people of the SADC countries with the aims and objectives of SADC;

- promote the principles of human rights and democracy within the SADC region;

- strengthen the implementation capacity of SADC by involving Parliamentarians of SADC activities.

In order to implement its objectives, the SADC-PF provides several programs for Democracy and Governance, Parliamentary Capacity Development, Regional Development and Integration, HIV/AIDS and Public Health as well as Gender Equality and Empowerment. ${ }^{1037}$ Regarding the HIV and AIDS; both diseases which are widely spread in the area, the SADC-PF adopted a Model Law. The objective was to establish a legal framework in order to review and reform national legislation relating to HIV and which is conform with international human rights law standards. Furthermore, the model law seeks to promote effective prevention, treatment, and programs on HIV and AIDS. Lastly, the Model Law wants to ensure the protection and respect of the human rights of the sick people in the region. ${ }^{1038}$

\footnotetext{
1033 SADC Parliamentary Forum, Strategic Plan 2006-2010, 13.

1034 Consultative Meeting Report of the National Assembly of Namibia Windhoek, Namibia, 1993, 41.

1035 SADC Parliamentary Forum, Strategic Plan 2011-2015, 11; see also: M. J. Wade, \& W. J. Russell, The Short Constitution (1921), 34.

1036 Terlinden (2005), 24.

1037 See: Art. 3 of the 1999 Constitution of the SADC Parliamentary Forum.

1038 Musavengana (2011), 24.
} 
Other aims of the SADC-PF involve stepping up the defense of women's rights and facilitating the implementation of a SADC Protocol. ${ }^{1039}$ Most of the other programs aim to promote the rule of law within the region. Most recently, the SADC-PF pushed towards the development of a Model Law of Elections under the Standing Committee of Democratization, Governance and Human Rights, which is enabled to lead to a facilitation of the domestication of electoral instruments. ${ }^{1040}$

During the Round Table discussions in Lusaka in 2005, Ulf Terlinden analyzed the authorities of the SADC-PF in detail: He pointed out that the Executive - in the case of SADC the SADC Summit, is not obliged to follow any advice given by the Parliamentary Forum. ${ }^{1041}$ In addition to that, the SADC-PF does not have any oversight role over the SADC executive since it does not have a mandate to set up Investigation Committees. ${ }^{1042}$ He determined that the SADC-PF at least has the power to make recommendations regarding the budget of SADC and the SADC Executive annual report; ${ }^{1043}$ nevertheless, the SADC Summit need not take such recommendations into account. ${ }^{1044}$

With regard to any law-making powers, the SADC-PF does not have such mandate - besides the development of Model Law - nor does it have any power to enforce decisions or to secure the adherence of Member States. ${ }^{1045}$ Only with regard to some practical parliamentary activities, the SADC-PF seems to hold quite a strong mandate - the compilation of programs for new parliamentarians, the observation of elections and the establishment of gender standards. ${ }^{1046}$

The SADC-PF set up an observation program, concerning inter alia norms and standards for elections within the SADC region in 2001, to ensure peaceful, free and fair elections in the whole SADC area. ${ }^{1047}$ The main objective of these norms and standards is the strengthening of 'the democratic process and transparency in the conduct of elections in SADC countries.' ${ }^{1048}$ In addition to that, the norms and standards provide a gender checklist, with the purpose of ensuring gender equity in election processes. ${ }^{1049}$

\footnotetext{
1039 Mataranyika (2007), 8.

${ }^{1040}$ M. Magdaza, 'Sadc PF Plenary ups momentum', Herald (19 December 2017) available at: http://www.herald.co.zw/sadc-pf-plenary-ups-momentum/, (last visited: 22 July 2018).

1041 See: Art. 8(c)(iii)(iv) of the 1999 Constitution of the SADC Parliamentary Forum.

1042 Terlinden (2005), 19.

1043 See: Art. 8 (3 vii, viii) of the 1999 Constitution of the SADC Parliamentary Forum.

1044 Terlinden (2005), 25.

1045 See: Art. 8 (3)(b) of the 1999 Constitution of the SADC Parliamentary Forum.

1046 Terlinden (2005), 25.

1047 See: Statement by the SADC Parliamentary Forum, Election observation mission, Zimbabwe Presidential Elections, 2002.

1048 See: SADC Parliamentary Forum Election Observation Mission, Statement on the Elections in South Africa, 1.

1049 See: Parliamentary Forum Election Observation Mission, Statement on the Presidential and Parliamentary Elections in Malawi, Ch. 2, 8.
} 
The SADC-PF provides several programs to the national parliaments inter alia through leadership development, training, research, best practices and information sharing, quality publications and legislative support to perform their oversight, to support national parliaments with the challenges they face. ${ }^{1050}$

Regarding the Constitution of the SADC Parliamentary Forum, it is still planned to eventually elevate the Parliamentary Forum to a full legislative assembly. ${ }^{1051}$ However, the Constitution states that the legislative assembly should never in any way infringe 'on the sovereignty of SADC national parliaments. ${ }^{\text {'052 }}$ This regulation is raising the question if there really does exist a common agenda of the SADC Member States to transform the SADC Parliamentary Forum into a workable legislative body.

\subsection{Conclusion on the SADC Parliamentary Forum}

The SADC Parliamentary Forum does not have great influence on the protection of the rule of law and especially the protection of human rights within the SADC region. In the past, the SADC-PF developed several model laws - they are, however, not of binding character and thus do not have any direct impact of the standard of democracy and human rights. The SADC-PF is not an official institution within the SADC institutional structure. Art. 9 of the SADC Treaty does not mention the establishment of a SADC Parliament.

The election procedure of the members of the SADC-PF does not comply with democratic principles since it does is not universal since national parliaments are eligible to elect the members of the SADC-PF. Thus, the current governments of each Member State still have great influence in the composition of the SADC-PF.

Until today, there is not yet much evidence that decisions of the SADC-PF are of influence for any decisions in the SADC region. Regrettably the SADC-PF has no decision-making power, only consultative power; it also consists of only a few members. Currently, the Summit holds the final decision-making power and thus the Parliamentary Forum is not yet recognized as a legislative institution by the Summit. This is why the activities of the SADC-PF, remain mostly unknown within the region. This is why, activities, such as the observations of national elections in the region and its Model Law with regard to HIV and AIDS remain mostly unnoticed by the regional policy-making organs and SADC citizens.

However, in contrast to most other REC's in Africa, the SADC-PF enjoys financial independence since the Plenary Assembly, Executive and Secretariat decide when and where the financial resources are needed. Financial resources are dependent on national treasuries. Thus, the SADC-PF already at some points took positions that have not been in conformity with the general positions of the SADC. ${ }^{1053}$

\footnotetext{
1050 See: SADC Parliamentary Forum, Strategic Plan 2011-2015, iii.

1051 See: Art. 8 (3)(b) of the 1999 Constitution of the SADC Parliamentary Forum.

1052 Ibid.

${ }^{1053}$ Musavengana (2011), 77.
} 
A possible transformation of the SADC-PF towards a regional parliament would lead to greater links with other SADC institutions since the SADC Parliament could then be transformed into an official institution of SADC under the provisions of Art. 9(2) of the SADC Treaty, which allows the establishment of further institutions if deemed necessary.

Such transformation of the SADC-PF might also create the opportunity to have a greater oversight rule. Furthermore, the SADC Parliament has greater influence regarding the approval of new protocols in the national parliaments which finally could lead to greater achievements regarding the implementation of the objectives of the SADC.

SADC is, as the founding chairperson of the SADC PF, Dr. Mose Tjitendero stated: '[...] for lack of a better word, executive-orientated.' 1054

Recently Dr. Esau Chiviya, representing the Secretary General of the Southern African Development Community Parliamentary Forum, emphasized the importance of the transformation of the SADC Parliamentary Forum into a SADC Regional Parliament. He pointed out that a SADC Parliament is still lacking in the 'supposed three arms of SADC. ${ }^{1055}$ Chiviya further noted that the regional trade agreements of East and West Africa comprised a regional parliament and 'there is, therefore, a stronger case now for the transformation of SADC.' ${ }^{1056}$ In spite of much lobbying, the Regional Indicative Strategic Development Plan (RISDP) remains silent about the future role of parliamentarians in matters of regional development and integration. ${ }^{1057}$ In 2004, during the $16^{\text {th }}$ Plenary Assembly Session, Ntlhoi Motsamai expressed the opinion that a SADC Parliament would 'accelerate the pace of socio-economic and political development and integration through the speedy ratification of SADC Protocols.' ${ }^{1058}$ In her speech, she addressed the problem of the ratification of a new SADC Protocol, which could take several years since fourteen national parliaments had to ratify it. At the same time, she stressed that the SADC region 'risks being left behind in the developments taking place at the continental level', since it is one of the few regional agreements that as yet do not provide a regional Parliament. ${ }^{1059}$

As the transformation of the SADC-PF should not impair the sovereignty of any national parliament, the exact nature of a future regional parliament has yet to be clarified. ${ }^{1060}$ The establishment of a regional parliament has most recently gained more support within the region since the current South African president Cyril Ramaphosa stated that the parliamentary democracy is necessary to take into ac-

\footnotetext{
1054 Ibid.

1055 C. Barasa, 'Southern Africa: Proposal for SADC Parliamentary Forum', allAfrica (17 May 2016), available at: http://allafrica.com/stories/201605170135.html, (last visited: 14 June 2016).

1056 Ibid.

1057 Musavengana (2011), 1.

1058 'Southern Africa: SADC Party for Regional Integration', available at: https://allafrica.com/ stories/200406040936.html, (last visited: 9 September 2018).

1059 Ibid.

${ }^{1060}$ Musavengana (2011), 32.
} 
count the will of the people. It is proposed that the Secretary of the SADC-PF would continue to be the Secretary of the regional parliament. Further, the new regional parliament might hold rotating sessions within the several Member States. ${ }^{1061}$ The question arising from this requirement of the SADC-PF Constitution is: what powers the proposed regional parliament should hold as the establishment of a regional parliament usually impinges on countries' sovereignty. ${ }^{1062}$

Most recently, during the Summit of the SADC-PF in Cape Town, the members of the institution pushed towards a greater role within SADC. The Speaker of the institution asked the Summit of Heads of States to join their next Summit in order to explore the option of cooperation. The Speaker of the Parliamentary Forum stated that '[...] We don't want a situation where we rubber-stamp something we only hear of when it is brought to our parliament, although negotiations clearly are the responsibility of the executive. ${ }^{1063}$ The Speaker stated that a body with powers similar to the European Parliament should be established. The European Parliament is mandated to give votes on several trade-related topics. However, Member States keep the final ratification powers. ${ }^{1064}$

Nevertheless, another recent and important achievement of the SADC-PF regarding human rights protection is the adoption of the first model law regarding child marriage in the SADC region, which advises Member States to harmonize their particular national laws to prohibit child marriage. ${ }^{1065}$ The developed model law should provide guidance to the ministries of justice and parliamentarians of SADC Member States to develop their national laws. ${ }^{1066}$

\subsection{Final Conclusion on the Southern African Development Community}

Due to the demise of the SADC Tribunal and the thereto-related establishment of the new SADC Tribunal, the judicial protection of the rule of law in the whole SADC region - especially with regards to human rights got limited. Owing to the efforts of

${ }^{1061}$ D. Majaha, 'Proposed SADC regional parliament garners support', The Southern Times (23 August 2018), available at: https://southerntimesafrica.com/site/news/proposed-sadcregional-parliament-garners-support, (last visited: 24 August 2018).

1062 Musavengana (2011), 33 et seq.

1063 E. Randall, 'SADC urges pan-African parliament debate', IOL (21 April 2000), available at: https://www.iol.co.za/news/africa/sadc-urges-pan-african-parliament-debate-35232, (last visited: 20 May 2017).

1064 Ibid.

1065 'SADC Parliamentarians adopt Model Law on eradicating child marriage, Girls not Brides' (4 June 2016) available at: https://www.girlsnotbrides.org/sadc-model-law-child-marriage, (last visited: 15 September 2018).

1066 Official Website of the United Nations Population Fund, Landmark move against child marriage (20 June 2016), available at: https://esaro.unfpa.org/en/news/landmark-move-against-childmarriage, (last visited: 15 September 2018). 
the former Zimbabwean President Robert Mugabe, individuals have been deprived of access to the Tribunal which now decides on intra-states disputes only. Due to the recent jurisdiction of the South African Constitutional Court with regard to the Fick case, it is, however, possible to enforce jurisdictions of the SADC Tribunal through South African courts. In the future, people living in the SADC region may, however, be able to bring more cases involving human rights issues to the African Commission, which may forward such cases to the African Court of Human and Peoples' Rights. The decisions of the Court are enforceable in the SADC region but since access to the Court is very limited, the African Commission remains the most important actor in this regard. Also, citizens of SADC Member States, which are at the same time members of COMESA - which will be discussed in detail in chapter 7 - and may, therefore, bring forward claims to the COMESA Court.

Regarding the legislative, ensuring the popular participation, SADC does not provide for a regional parliament. SADC-PF is not officially integrated within the institutional structure of SADC. There are many voices trying to push towards the establishment of a fully flagged Parliament - however, there is still not enough political will to realize such an idea.

Thus, at the moment, especially due to the ill achievements of the former Zimbabwean Government, the level of the promotion of the rule of law including the protection of human rights as well as the level of popular participation remains very low in the SADC area. It remains to be seen if the new Zimbabwean President Emmerson Mnangagwa campaigns towards a greater promotion of such principle. 



\section{Chapter 6: \\ The East African Community (EAC)}

\subsection{Introduction}

The East African Community (EAC) currently encompasses a geographical area of about 1.82 million square kilometres with a population of around 133 million people. ${ }^{1067}$ The EAC Treaty, giving rise to the Community, was signed on 30 November 1999 and came into force on 7 July 2000 after the ratification of the founding Member States. The EAC was initially established in 1967 but collapsed in 1977.1068

It is a multilateral body with the objective of performing various functions for and on behalf of Member States. ${ }^{1069}$ Since its inception the EAC Member States went through positive political development and have managed to hold several multiparty elections. ${ }^{1070}$

\footnotetext{
${ }^{1067}$ A. Kuteesa, 'East African Regional Integration: Challenges in Meeting the Convergence Criteria for Monetary Union: A Survey', 4 International Journal of Economics and Finance (2012), 147.

1068 Possi (2013), 176.

1069 W. LO. Oluoch, 'Legitimacy of the East African Community', 53 Journal of African Law (2009), 194, 195.

1070 Kleis (2016), 88.
} 
Currently, all the Member States of the EAC, except Tanzania, are also members of the Common Market for Eastern and Southern Africa (COMESA). ${ }^{1071}$ Similar to the Economic Community of West Africa, the idea of regional cooperation within East Africa developed quite early.

\subsection{History of the East African Community}

The history of the East African Community began in the early 1900s. The British colonial powers during the early colonialism had already attempted to achieve closer economic co-operation between the East African countries.

\subsubsection{Regional integration in East Africa under British colonialism}

While the territories of Uganda and Kenya and later also Tanganyika ${ }^{1072}$ have been under the British colonial power, the British were keen to install a common railway system, post office as well as a common airline, with the objective to reduce the financial obligations imposed on the British Exchequer. ${ }^{1073}$ The Governors' Conference was the first executive organ of the three territories, composed of the respective three governments, with the first convention taking place in $1926 .{ }^{1074}$

In 1947 the British Government implemented the High Commission with the objective of changing the lack of legal power of the Governors' Conference. ${ }^{1075}$ They further established the Central Legislative Assembly, whose members were elected by the Legislative Council of each territory. ${ }^{1076}$ It only had very limited powers, since the bills presented by this institution, in general, had to be approved by the High Commission. ${ }^{1077}$

\footnotetext{
${ }^{1071}$ G. Kennedy, H. Sippel \& U. Wanitzek, Processes of legal integration in the East African Community (2011), 105.

1072 Tanganyika has been a sovereign state that existed between 1961 and 1964. On 26 April 1964 , Tanganyika acceded to the People's Republic of Zanzibar and Pemba and formed the United Republic of Tanzania. see: M. Katundu, 'Tanzania's Constitutional Reform Predicament and the Survival of the Tanganyika and Zanzibar Union', 8 The Journal of Pan African Studies 3 (2015), 104.

1073 EASSI, The East African Community Customs Union: Women \& Cross Border Trade in East Africa (2012), available at: https://www.eassi.org/wp-content/uploads/2018/08/WomenInformal-Cross-Border-Traders-Opportunities-and-Challenges-in-the-EAC-Action-research2012.pdf, (last visited: 9 September 2018), 18.

1074 P. Sebalu, 'East African Community', 16 Journal of African Law (1972), 345.

1075 V. H. Umbricht, Multilateral Mediation, Practical Experiences and Lessons (1989), 10

1076 Sebalu (1972), 349.

1077 Umbricht (1989), 11.
} 
After the independence of Tanganyika in 1961, it was agreed between the remaining territories under the British colonial rule, that the common services administered by the High Commission should continue. ${ }^{1078}$ In order to maintain these services and replace the High Commission, the East African Common Services Organization was established in $1961 .{ }^{1079}$

\subsubsection{Decolonization and associated movement to independence within East Africa}

When Uganda and Kenya gained independence in 1962 and 1963 respectively, the possibility of a federation between these territories was considered. ${ }^{1080}$ When the federation did not materialize, a common market was founded in order to find a compromise. ${ }^{1081}$ Consequently, in 1967, the Treaty establishing the East African Co-operation (EAC) came into force with key organs such as the East African Authority, the Committee of East African Ministers, the Secretary, the East African Legislative Assembly, the Common Market Tribunal and the East African Development Bank (EADB). The EAC respectively adapted all the institutions, services and responsibilities that were previously part of the East African Common Services Organization.

Only about ten years later, in 1977 the Treaty for East African Co-operation was dissolved and the work of the EAC ended. ${ }^{1082}$ The reasons ${ }^{1083}$ for this decision included the lack of strong political commitment, the use of different economic systems, as well as a lack of fair distribution of the benefits gained by the community. ${ }^{1084}$

Art. 14.02 of the Mediation Agreement for the Division of Assets and Liabilities of the East African Co-operation, signed on 14 May 1984, provides inter alia that the involved three countries should still explore areas of future cooperation despite its dissolution. ${ }^{1085}$ The Act also declares that the Soroti Civil Flying School, the

\footnotetext{
1078 Scharfenberg (2014), 148.

1079 W. Masinde \& C. O. Omolo, 'The Road to East African Integration', in E. Ugirashebuja et al (eds), East African Community Law: Institutional, Substantive and Comparative EU Aspects (2017), 1, 15.

1080 Sebalu (1972), 347.

1081 R. B. Mshomba, Economic Integration in Africa - The East African Community in Comparative Perspective (2017), 50.

1082 W. Braude, Regional Integration in Africa: Lessons from the East African Community (2008), 63 et seq.

1083 For a general overview of the dissolution of the Original East African Community see A. Hazlewood, Economic integration: The East African experience (1975).

1084 The East African Community Customs Union: Women \& Cross Border Trade in East Africa (2012), 19.

1085 Oluoch (2009), 197.
} 
Inter-University Council of East Africa and the East African Development Bank should continue as common institutions after the dissolution of the East African Organization. ${ }^{1086}$

In 1991, at a meeting of Commonwealth Heads of Governments and States (CHOGS) in Harare, a mini-summit between the three States Kenya, Uganda and Tanzania was held, where the Heads of States of the respective States announced their common intention to re-launch the East African co-operation. ${ }^{1087}$ Hence, taking into consideration the worldwide movement towards the set-up of regional alliances, on 30 November 1993, the Heads of these three States signed the Agreement on the establishment of the Permanent Tripartite Commission for East African Co-operation. ${ }^{1088}$

Only about four years later, in 1997, negotiations for the transformation of the Tripartite Agreement into a Treaty establishing the East African Community (EAC) commenced. ${ }^{1089}$ The Treaty of the renewed EAC was finally signed in 1999 by Kenya, Uganda and Tanzania. ${ }^{1090}$ The Treaty came into force on 7 July 2000 and the EAC was officially launched on 15 January 2001 after the ratification of the Treaties. ${ }^{1091}$ Later, on 18 July 2007, Rwanda and Burundi joined the EAC. ${ }^{1092}$

\subsection{Objectives of the East African Community (EAC)}

The objectives of the EAC are listed in Art. 5 of the Treaty: Art. 5(1) respectively states that the objectives of the Community shall be 'to develop policies and programs aimed at widening and deepening co-operation among the partner States in political, economic, social and cultural fields, research and technology, defense, security and legal and judicial affairs for their mutual benefit.'

After launching the EAC Common Market on 1 July 2010, the EAC focused on the establishment of an East African Monetary Union until 2012. With this undertaking and the establishment of a common EAC currency, a boost in the investment climate is expected. In this context, it has to be mentioned that in recent years, many East African companies had been established through cross-border investments, which were dominated by mergers and acquisitions. This is a clear indication of the existing potential for large investors who are regarding East Africa as an in-

\footnotetext{
1086 See: Art. 14.01 of the 1984 East African Mediation Agreement Act.

1087 Scharfenberg (2014), 154 et seq.

1088 Oluoch (2009), 197.

1089 E. Mugisa, C. Onyango \& P. Mugoya, 'An Evaluation of the Implementation and Impact of the East African Community Customs Union', EAC (2009), available at: https://www.academia. edu/27637527/An_Evaluation_of_the_Implementation_and_Impact_of_the_East_African_ Community_Customs_Union, (last visited: 9 September 2018), 2.

1090 Kuteesa (2012), 147.

1091 Oluoch (2009), 212.

1092 Scharfenberg (2014), 156.
} 
vestment destination of choice. ${ }^{1093}$ Prof. Mahmood Mandani is of the opinion that 'it seems likely that the introduction of an East African currency without first creating a common political framework and solving the question of sovereignty, would invite difficulties along the similar lines of those now facing the EU.' ${ }^{1094}$ The EAC is currently giving much attention to infrastructure such as power, water, roads, railways, ports and harbours, telecommunications and information technologies, which also encourage investment in East Africa. ${ }^{1095}$ Furthermore, citizens of the EAC region are eligible for free movement within the area without any visa requirements but may not choose a place of work or residence. ${ }^{1096}$

The final future objective is the transformation of the EAC Community into a political federation, Art. 5(2) of the Treaty. ${ }^{1097}$

\subsection{The Organs of the East African Community (EAC)}

Chapter 3 of the Treaty of the East African Community stipulates the establishment of the respective organs of the Community. According to Art. 9(1) of the Treaty, the Summit, the Council, the Co-ordinating Committee, Sectoral Committees, the East African Court of Justice, the East African Legislative Assembly and the Secretariat are the designated organs. Besides that, the EAC provides for several institutions, such as the East African Development Bank, Lake Victoria Fisheries Organization and other institutions of the former East African Community.

The Summit consists of the Heads of State or Government of the respective Member States and is mandated to provide general direction and impetus in order to achieve the objectives of the Community. In order to discharge its functions, the Summit is competent to consider all reports of the other organs and to review the condition of peace, security, and good governance within the Member States. ${ }^{1098}$ The Summit, as the supreme organ of the Community generally meets once a year and makes decisions in consensus, as per Art. 12(1)(3).

In line with Art. 13(a)(b), The Council of Ministers consists of the ministers that are responsible for regional co-operation within the Community and other ministers that are selected for this function. The Council is the policy organ of the Community and, in accordance with Art. 14(2)(a) is mandated to review the implementation of the programs of the Community and thus may make policy

\footnotetext{
1093 J. Ochwada, 'Principles of Operation and Development Strategies in the East African Community', in K. Gastorn, H. Sippel \& U. Wanitzek (eds), Processes of Legal Integration in the East African Community (2011), 77.

1094 Kennedy et al (2011), 12.

1095 Ochwada (2011), 77.

1096 Peter-Berries (2010), 65.

1097 A. Possi, 'Striking a Balance between Community Norms and Human Rights: The Continuing Struggle of the East African Court of Justice', 15 Afr Hum Rts LJ (2015), [i], 199.

1098 See: Art. 11(1-3) of the 1999 Treaty for the Establishment of the East African Community.
} 
decisions on such matters, which are of binding character to the Member States, as per Art. 16. Under the provision of Art 15(1)(2), the Council meets twice a year and shall implement its own rules of procedure.

The Co-ordination Committee consists of the Permanent Secretaries which, pursuant to Art. 17, are responsible for the affairs of the East African Community. In accordance with Art. 18, the Committee is inter alia designated to implement decisions of the Council and to submit recommendations to the Council.

The Community further provides for several Sectoral Committees, which are to be set up by the Council, as laid down in Art. 20. The Sectoral Committees are meant to ensure the implementation of the programs related to their sector and to submit recommendations to the Council, as per Art. 21. In accordance with Art. 22, the Committees shall meet as often as necessary.

Under Art. 24 of the 1999 Treaty of the EAC, the East African Court is the juridical body within the Community and is mandated to ensure the adherence to law and the interpretation of the Treaty.

Art. 48 of the Treaty stipulates that nine members and ex-officio members that are elected by each Member State form part of the Legislative Assembly.

Similar to SADC the Secretariat is deemed to be the executive organ of the Community, headed by a Secretary General, in line with Art. 66. In accordance with Art. 71, the Secretariat receives and submits recommendations to the Council and forwards bills to the Legislative Assembly through the Coordination Committee. The Secretariat may also initiate studies with regard to the implementation of the implementation of the programs of the Community.

\subsection{Human Rights Protection through the East African Court of Justice}

The effective and independent jurisdiction of the East African Court of Justice would have a great effect on the protection of the rule of law within the Member States of the EAC.

The EAC Treaty, in Art. 9(1)(e) provides for the establishment of the East African Court of Justice (EACJ) as the judicial organ within the East African Community.

The objective of the East African Court (EACJ) is to ensure adherence to the law of the East African community. ${ }^{1099}$ The organ was created in 1999, finally becoming operational in 2001. ${ }^{1100}$ Currently, the Court is situated in Arusha, Tanzania. The EACJ is the institutional successor of the East African Court of Appeal, which was the judicial organ of the former East African Community. ${ }^{101}$

\footnotetext{
1099 Scharfenberg (2014), 170.

1100 Kleis (2016), 541.

1101 Possi (2013), 180.
} 


\subsubsection{The Structure of the East African Court of Justice}

Art. 23(1) of the EAC Treaty provides for two divisions within the EACJ: a high court and an appellate division. ${ }^{1102}$ The EACJ in total comprises ten judges - five for each division. ${ }^{103}$

The judges of the EACJ are usually appointed by the respective Member States of the EAC, which are then selected by the Summit. The judges need to comply with several requirements, such as proven integrity, impartiality and independence. ${ }^{1104}$ Furthermore, the judges have to demonstrate acknowledged competence and experience in the particular Member States to qualify them to hold such a high judicial office. ${ }^{1105}$

The Summit is further authorized to choose two judges as president and vice-president of the appellate division, and another two as principal and deputy judges of the high court. ${ }^{1106}$ The president of the Court is, apart from directing work to the appellate division, responsible for all forms of administration and supervision of the Court of the East African Community. ${ }^{1107}$ The Treaty, however, does not regulate the gender equality regarding the Court's composition. This is interpreted to be a drawback for women in the EAC, whose position, with regards to gender equality, is generally strengthened by the Treaty. ${ }^{1108}$

The EAC Treaty stipulates that a judge generally holds office for seven years unless they turn 70 , resign or are removed from their mandate. ${ }^{1109}$ The removal of a judge from office has to be authorized by the Summit: the Summit may suspend a judge from his or her mandate in the EACJ in the following cases: for misconduct or inability to perform such a high office, where a judge holds another public office in a partner State and has been removed from that office due to misconduct, where a judge is declared bankrupt and where an ad hoc independent tribunal is convened by the Summit. ${ }^{1110}$

With regard to second employment, the judges are not allowed to hold 'any political office ${ }^{1111}$ ' or any other office that serves one of the EAC Member States or the EAC, nor be engaged in any trade, profession or vocation that could raise a

\footnotetext{
1102 See: Art. 23(2) of the 1999 Treaty for the Establishment for the East African Community.

1103 Oluoch (2009), 203.

1104 See: Art. 24 (1) and Art. 24(2) of the of the 1999 Treaty for the Establishment of the East African Community.

1105 Oluoch (2009), 203.

1106 See: Art. 9 (b) of the 1999 Treaty for the Establishment of the East African Community.

1107 Oluoch (2009), 204.

1108 Ibid., 206.

1109 See: Art. 25 of the 1999 Treaty for the Establishment of the East African Community.

1110 See: Art 26 (1) of the 1999 Treaty for the Establishment of the East African Community.

1111 See: Art. 43(2) of the 1999 Treaty for the Establishment of the East African Community.
} 
conflict of interest. ${ }^{1112}$ It may be argued that in cases where the Court works on $a d$ hoc basis as provided in Art. 140(4) of the Treaty, Art. 43(2) of the Treaty does not apply. Art. 140(4) states:

Until such time as the Council determines that the Court is fully operational, a Judge appointed under Art. 24 of this Treaty shall serve on an ad hoc basis. Notwithstanding the provisions of paragraph 5 of Art. 25 of this Treaty, the salary and other terms and conditions of service of a Judge serving on an ad hoc basis shall be determined by the Summit on the recommendation of the Council.

Wauna LO Oluoch, however, feels that 'this argument cannot stand, given the plain distinctive meaning of the two articles.' 1113

At the time of appointment, some judges were holding offices at a domestic court, and furthermore, some of the judges were refusing to withdraw from their national office while working at EACJ, which led to several conflicts. ${ }^{1114}$

\subsubsection{Access to the East African Court of Justice}

According to the EAC Treaty, all citizens of the EAC have access to the Court. ${ }^{1115}$ The Treaty states that every citizen shall have the right to review the legitimacy of any Act, regulation, directive or decision of a Member State, as per Art. 23 of the Treaty. Unfortunately, not many citizens of the EAC Member States possess the knowledge as to the remedies available to them through such a subregional court. Hence, one fears that only a very small number of EAC citizens eventually have access to the Court. Furthermore, the fact that the majority of EAC citizens are not able to afford the high legal costs that go with a claim before the EACJ, aggravates the situation. ${ }^{1116}$

\subsubsection{The jurisdictional mandate of the East African Court of Justice}

The jurisdiction of the EACJ is regulated by Art. 27(1) of the Treaty which stipulates that the Court has "jurisdiction over the interpretation and application of this treaty.' 1117 Moreover, the Court has jurisdiction over upcoming disputes between employees and Member States. ${ }^{1118}$

\footnotetext{
1112 Ibid.

1113 Oluoch (2009), 204.

1114 Scharfenberg (2014), 191 et seq.

1115 See: Art. 30 (1) of the 1999 Treaty for the Establishment of the East African Community.

1116 J. Lehmann, Wirtschaftsintegration und Streitbeilegung außerhalb Europas (2003), 264.

1117 Phooko (2015), 541.

1118 Oluoch (2009), 206.
} 
The Court was originally established to resolve questions regarding customs and common market. However, thus far the EACJ had not been used to solve any cases on these topics. ${ }^{119}$ Only in November 2005, the Court received its first case Calist Andrew Mwatela \& Others v. East African Community ${ }^{1120}{ }^{1121}$ Shortly before the submission of the first case, a scholar declared the EACJ 'stillborn, not only because it had not yet decided any cases but also because the Treaty had given it extremely restrictive jurisdiction by expressly declining to allow it to hear human rights cases.' ${ }^{1122}$

The Council of Ministers has the authority to extend the jurisdiction of the EACJ if deemed necessary. ${ }^{123}$ Art. 27(2) of the EAC Treaty states that the Court 'shall have such other original, appellate, human rights and other jurisdiction as will be determined by the Council at a suitable subsequent date. To this end, the partner States shall conclude a protocol to operationalize the extended jurisdiction.'

This regulation gives the impression that the EAC Member States planned to develop the jurisdiction of the EACJ in phases. ${ }^{1124}$ For example, the Council of Ministers has not yet broadened the jurisdiction of the Court regarding the protection of human rights. ${ }^{1125}$ In the past, human rights lawyers within East Africa urged the EACJ to finally adjudicate violations of human rights and the principles of rule of law.

It is purported that, due to several reasons, the EACJ does have jurisdiction regarding human rights. ${ }^{1126}$ One opinion states that the mandate of jurisdiction over human rights is given through inter alia the high number of references within the EAC Treaty to human rights. ${ }^{1127}$ Art. 6 of the Treaty refers to some fundamental principles, such as the protection of human and people's rights, in accordance with the African Charter on Human and People's Rights, as well as the principles

\footnotetext{
1119 Viljoen (1999), 198.

1120 Calist Andrew Mwatela \& Others v. East African Community, Taxation Number 1f 2006, Judgment of 1 November 2007.

1121 The case was brought by members of the EALA against the EAC to end an ongoing power struggle between the Council and the EALA over the EALA's legislative power. Art. 49 of the EAC Treaty states that EALA was the legislative organ of the Community. The Council conversely promulgated 15 Protocols regarding different EAC integration issues without involving the EALA in the process and thus EALA members argued that these actions were contrary to the EAC Treaty. The EACJ in its finding stated that the Council acted inconsistent with the EAC Treaty. The Court invalidated the decisions of the Council to 'withdraw the bills other than through the legislative process', see: ibid., 1.

1122 J. Gathii, 'Mission Creep or a Search for Relevance: The East African Court of Justice's Human Rights Strategy', 24 Duke J Comp \& Int'l L (2013), 249, 262.

1123 See: Art. 23 and read with Art. 27 (2) of the 1999 Treaty for the Establishment of the East African Community; see also: ibid., 253.

${ }_{1124}$ Murungi \& Gallinetti (2010), 123.

1125 Possi (2013), 194.

1126 Phooko (2015), 541.

1127 Possi (2013), 195.
} 
of democracy. Hence, it could be argued, that the Treaty itself already includes a mandate of jurisdiction over human rights, even in the absence of an adoption of an additional protocol. ${ }^{1128}$

The Tribunal has already delivered several judgments over some cases that included issues on human rights. ${ }^{1129}$ According to MR Phooko, it is absolutely necessary for the Tribunal to exercise a human rights jurisdiction, since the fulfillment of the EAC's objective would be restricted if fundamental principles such as the rule of law, human rights, and democracy are undermined. ${ }^{1130}$ Some of the human rights cases that have been brought before the EACJ include the following cases.

\section{a) Katabazi v. Secretary General of the East African Community}

The first case involving the violation of human rights which was decided by the EACJ was Katabazi v. Secretary General of the East African Community. In this case, the applicants had been charged with inter alia treason. They were thus arrested and had to remain in custody. ${ }^{1131}$ However, the High Court of Uganda granted bail to some of the accused. Shortly after the decision of the High Court, the building was surrounded by security personnel who re-arrested the accused. They were brought before a military court on similar charges. ${ }^{1132}$ The military court would not grant bail and the accused had to remain in prison. ${ }^{1133}$

The Ugandan Law Society persuaded the Constitutional Court to reconsider the case, upon which they found that the decision of the military court was not consistent with the Constitution of Uganda. The government chose to ignore this decision and thus the case was taken to the EACJ. ${ }^{1134}$

The EACJ in its findings stated that the re-arrest executed by armed security agents violated the principle of the rule of law as provided in the Treaty The Tribunal further stated that the arrest based on reasons of state security is 'a dangerous precedent, which would undermine the rule of law.' ${ }^{1135}$ Hence, the Tribunal stated that: '[It] will not assume jurisdiction to adjudicate on human rights disputes, it will not abdicate from exercising its jurisdiction of interpretation under Art. 27(1) merely because the reference includes allegation of human rights violation. ${ }^{1136}$ Moreover, the Court found that under the provisions of Art. 23 it has to ensure the adherence to the law. The Court then held that it has jurisdiction under Art. 27(1) to exercise

\footnotetext{
1128 Phooko (2015), 541.

1129 Murungi \& Gallinetti (2010), 124.

1130 Phooko (2015), 544

1131 James Katabazi and 21 Others v. Secretary General of the East African Community and another, Reference No. 1 of 2007, Judgment of: 31 October 2007, 1.

1132 Kleis (2016), 168.

1133 Katabazi and 21 Others v. Secretary General of the East African Community and another, 2.

1134 Ibid., 3.

1135 Ibid., 22.

1136 Ibid., 16.
} 
its powers under Art. 23. ${ }^{1137}$ By examining case law from the United Kingdom ${ }^{1138}$ and the Court of Appeal of Kenya, ${ }^{139}$ the Court found that it is obliged to 'provide a check on the exercise of the responsibility [...] to protect the rule of law.' ${ }^{\prime 1140}$

The Court further found that Art. 6(d), 7 and 8(1) of the Treaty are supposed to be central provisions and therefore argued 'that it would not ignore human rights references a case entails merely because it correctly assumed to lack jurisdiction for human rights applications. ${ }^{1141}$ Thus, since Arts. 5 to 8 have adhered to Art. 23, the Court had jurisdiction and was thus able to hear the case. ${ }^{1142}$ The EACJ then found that the intervention by the armed security agents of Uganda was unlawful and thus violated the provisions of the Treaty and the rule of law. ${ }^{1143}$

\section{b) Independent Medical Legal Unit v. the Attorney-General of Kenya}

Moreover, the Court had to decide the case of Independent Medical Legal Unit v. the Attorney-General of Kenya ${ }^{144}$, also involving the adherence to human rights.

In this case, the claimants stated that the failure of the Kenyan government to investigate and punish the offenders responsible for post-election violence in 2007 in the Mt Elgon District, which caused the death of nearly 3,000 innocent citizens, was inconsistent with the principles of the EAC Treaty. ${ }^{1145}$ They claimed that the lack of government intervention breached Arts. 6 and 7(2) of the Treaty. ${ }^{1146}$

The Court again stated that it does not have jurisdiction over human rights as per Art. 27(2) of the Treaty, which expressly excludes jurisdiction on human rights until the subsequent extension of the Protocol to the Court. But again, the EACJ found that it had jurisdiction to interpret the Treaty. Thus, in its opinion, if cases are brought to the Court, which involve the interpretation of the Treaty, such interpretation could not preclude human rights. The Court furthermore stated that the government of Kenya violated the Constitution of Kenya as well as several human rights instruments including the Universal Declaration of Human Rights. ${ }^{1147}$

\footnotetext{
1137 Gathii (2013), 256.

1138 See: R. v. Horseferry Road Magistrates' Court and another, ex parte Bennett, [1994] 1 A.C. 42.

1139 See: The Republic of Kenya v. Gachoka and another, MISC Criminal Application No. 60 of 2016, Judgment of 8 March 2016.

1140 Katabazi and 21 Others v. Secretary General of the East African Community and another, 23.

1141 Kleis (2016), 170.

1142 Alter et al (2016), 301.

1143 Katabazi and 21 Others v. Secretary General of the East African Community and another, 23.

1144 Independent Medical Legal Unit v. the Attorney-General of Kenya, Ref. No. 3 of 2010, Judgment of 15 March 2012.

1145 Possi (2015), 205.

1146 Independent Medical Legal Unit v. the Attorney-General of Kenya, 3.

1147 Ibid., 8 et seq.
} 


\section{c) Democratic Party v. The Secretary General of the East African Union}

In November 2013, The Democratic Party of Uganda brought a case ${ }^{1148}$ before the EACJ against the Secretary General, Uganda, Rwanda and Burundi and argued that the failure of the Member States to sign the Special Declaration with regard to the African Court on Human and Peoples Rights, violated Art. 5(3) and Art. 34(6) of the Protocol of the African Court. The appellant stated that the signing the Protocol to the African Charter on Human and Peoples' Rights on the Establishment of the African Court on Human and Peoples' Rights would constitute an obligation on Member States to sign the above-mentioned declaration. ${ }^{1149}$

Before, the First Instance division inter alia ruled that it has jurisdiction to ensure the adherence with the EAC Treaty but that it does not have jurisdiction to issue interpretations of the African Charter and the Protocol on the African Court on Human and Peoples' Rights. ${ }^{1150}$

The appellate division of the EACJ, however, stated that under the provisions of Art. 6(d) Member States need to adhere the principles of democracy, rule of law, transparency, accountability, social rights and the protection of human rights in accordance with the African Charter. The Court found that the wording in accordance with the provisions of the [...] Charter' creates the obligation for all EAC members to consider the provisions of the Charter. The appellate division, therefore, found that the EACJ is competent to refer to the international instruments such as the African Charter on Human and Peoples' Rights and the Vienna Convention. The international instruments are incorporated explicitly through Art. 6(d) and Art. 7(2) of the EAC Treaty, and thus, Member States need to comply with their provisions. ${ }^{1151}$

As to Art. 34 (6) of the Protocol to the African Court on Human and Peoples' Rights the Court found that since the provisions do not provide for a time limit, EAC Member States cannot be faulted under Art. 34(6). ${ }^{1152}$

The decision of the EACJ marks a big milestone with regard to the effectiveness and the protection of human and peoples' rights within the East African Community. However, the judgment may also cause political retaliation among the Member States. ${ }^{1153}$

1148 Democratic Party v. The Secretary General of the East African Community, Appeal No. 1 of 2014, Judgment of 28 July 2015.

1149 Hartzenberg (2011), 14.

${ }^{1150}$ Democratic Party v. The Secretary General of the East African Community, Appeal No. 1 of 2014, Judgment of 28 July 2015, 2 et seq.

${ }^{1151}$ Ibid., 9 et seq.

1152 A. Possi, 'It's official: The East African Court of Justice can now adjudicate human rights cases', AfricLAW (2016), available at: https://africlaw.com/2016/02/01/its-official-the-east-africancourt-of-justice-can-now-adjudicate-human-rights-cases/, (last visited: 6 July 2017).

1153 O. Windridge, 'No Need to Sign: Testing the Special Declaration at the East African Community Court of Justice', ACtHPR Monitor (17 September 2015), available at: http://www.acthprmonitor. $\mathrm{org} /$ no-need-to-sign-testing-the-special-declaration-at-the-east-african-community-court-ofjustice/, (last visited: 6 July 2017). 


\subsubsection{New Protocol on Jurisdiction on Human Rights}

Recently - taking into consideration the last judgments of the EAC Court - a proposal arose to provide for the EAC Tribunal with jurisdiction on human rights through the implementation of a new Protocol relating to the Court. In this context, the Justice Harold Reginald Nsekela, President of the East African Court argued:

If East Africans are serious about meaningful regional integration, the must be willing and prepared to invest in it, particularly in institutions that will make people develop with dignity. A fully-fledged East African Court of Justice with all its attendant jurisdictional rules is one such institutions. East African leaders cannot expect a strong East African Community unless they invest in institutions that will guarantee its existence. We should not expect to reap where we have not sown.

In the context of the introduction of the customs union and the common market, the Sectoral Council decided in 2009 that due to the increase of cross-border trade, investment and movement, the jurisdiction of the EACJ needed to be extended. ${ }^{1154}$

However, the much-anticipated Protocol with regard to the extension of jurisdiction on human right matters has not yet been signed by the Heads of Member States of the East African Community. The first draft of such a protocol was completed in 2005 but has not yet been successfully implemented. The process of the implementation of such a protocol is now part of a longer operation.

In April 2012, the East African Legislative Assembly (EALA) published a resolution appealing to the Summit of Heads of State to extend the jurisdiction of the Court in conformity with Art. 27 of the EAC Treaty. Furthermore, the EALA sought for the Council of Ministers of EAC 'to implore the International Criminal Court (ICC) to transfer cases of the Kenyans facing trial in respect of the aftermath of the 2007 General Election to the Arusha-based Court.'1155

The jurisdiction of the Court was, at last, extended in 2013 to such a level that it now includes has jurisdiction over international crimes such as genocide, crimes against humanity, war crimes and terrorism. ${ }^{1156}$

During the $16^{\text {th }}$ Summit of Heads of State of the EAC the participating governments signed the Protocol to Operationalize and Extend the Jurisdiction, with regard to trade and investment as well as matters being associated with the implementation of the Protocol on the Establishment of the East African Monetary Union. ${ }^{1157}$

\footnotetext{
1154 Possi (2013), 182 et seq.

1155 Possi (2016).

1156 Z. Ubwani, 'Lawyers in push for more regional court powers', The Citizen Tanzania (2 February 2014), available at: http://www.thecitizen.co.tz/News/Lawyers-in-push-for-more-regional-courtpowers/1840340-2169666-pipeyd/index.html, (last visited: 6 July 2017).

1157 C. Ligami, 'EACJ to handle criminal offences', The East African (7 December 2013), available at: http://www.theeastafrican.co.ke/news/EACJ-to-handle-criminal-offences/2558-2103006w3mjrs/index.html, (last visited: 17 July 2017).
} 


\subsection{Conclusion on the East African Court of Justice}

Similar to the other regional courts of the region, the EACJ initially remained inactive due to a lack of cases. However, with more and more cases coming its way that has soon changed. From the beginning, the Court enjoyed a lot of support from NGOs and Civil Societies in the East African Region.

One issue regarding the EACJ - again similar to the other regional courts of the continent - is the way it is constituted: generally, the partner States of the EAC have the authority to appoint judges. Hence, there is no other body within the $\mathrm{EAC}$ that has either the mandate to ensure the competence of the judges nor one to vet the nominated candidates. Appointments of judges by Member States are essentially 'rubber-stamped' by the Summit. The Treaty is silent about the functions of the Summit in this regard. According to the Treaty, the Summit is not required to asses the qualifications and suitability of nominated judges. Likely, the process of appointment could be influenced by some political concerns that might raise questions regarding the independence of judges. ${ }^{1158}$ This practice infringes on the EACJ's mandate, which includes that appointed judges take responsibility for the correct application of the Community law within the EAC. Moreover, it has to be noted that none of the judges inaugurated at the EACJ was recommended by any of the Member States - it appears that the governments of Member States use these appointments as a reward for the best judges of their national court. ${ }^{159}$

More than ever, the realization of the individual human rights remains a privilege of the elite and hence are often far-removed from and inaccessible to average EAC citizens.

Thus far, there are still issues regarding the accessibility to the EACJ: in general, the poor population requires more information about the EACJ in order to gain awareness and thus access to the forum. This information could be spread through several community programs. ${ }^{1160}$

Another concern that needs to be resolved is the strong influence of politicians on the extent of the jurisdiction of the EACJ. ${ }^{1161}$ The Council has yet to adopt a Protocol that was tabled in 2005, emphatically proposing the extension of the EACJ jurisdiction to human rights. ${ }^{162}$

The Court - in order to strengthen its political legitimacy - managed to gain the support of a significant network of pro-democracy civil society groups as well as lawyer associations. This network may be one reason why the governments did not

\footnotetext{
1158 Scharfenberg (2014), 191.

1159 Oluoch (2009), 204 et seq.

1160 Ibid., 206.

1161 Possi (2013), 201

1162 Oluoch (2009), 205.
} 
initiate the disbandment of the Court - similar to the SADC Tribunal, which did not provide for a powerful network and therefore was more vulnerable to intervening politics. ${ }^{1163}$

Nevertheless, the EACJ tries to define its mandate of jurisdiction itself: at the very beginning, in the Katabazi v. Secretary General of the East African Community case, the EACJ did not decide what rights a claimant had in the light of Art. 27(2) of the Treaty and thus, even legal counsels did not exactly know what they could claim for. ${ }^{1164}$ Later on, the EACJ stated in other cases, such as the Sebalu ${ }^{1165}$ case, that the Courts needs to become accessible for community citizens urgently. ${ }^{1166}$

Since the EACJ - in contrast to the SADC Tribunal - currently has many principal supporters, such as lawyer associations and pro-democratic civil society groups, it has not yet been eliminated yet by the Member States. ${ }^{1167}$ After the decision in the case of the Prof Anyang' and Ten Others v. Attorney General of the Republic of Kenya and Five Others, the Kenyan government tried to initiate amendments to the Treaty of the EAC to decrease the independence of the judges and the authority of the Court. ${ }^{1168}$ Furthermore, adding to the problem of extension of the jurisdiction, the EACJ is also still confronted with several institutional issues such as insufficient budget to fund all the procedures, insufficient staff, and the ad hoc basis on which most judges serve. ${ }^{1169}$ Furthermore, with the attempt of the Summit to receive competences on the impeachment of the judges of EACJ through the amendment of Art. 26 of EAC Treaty, than was litigation issue in the case East African Law Society v. Attorney General of Kenya and Others shows that the Summit does not just ignore the decisions of the Court, but rather takes them seriously. ${ }^{1170}$

However, the effects of the extension of the jurisdiction of the EACJ to try international criminal law, are yet to be seen. The punishment of international crimes has a linkage to human rights. However, the prosecution of international crimes as stated above regarding the African Court of Human and Peoples' Rights is very costly. Similar to the AU, the EAC is often confronted with shortages regarding its financial resources. Thus, it is doubtful whether there will be enough funding for the prosecution of international crimes in the near future. The addition of the juris-

\footnotetext{
1163 Gathii (2013), 259 et seq.

1164 Kleis (2016), 172.

1165 Hon. Sitenda Sebalu v. The Secretary General of the East African Community, Ref. No 8 of 2012, Judgment of 22 December 2013; The failure by the Council of Ministers/Sectoral Committee on Legal and Judicial Affairs to implement the judgment of the Court in Reference No. 1 of 2010 and Taxation Cause No. 1 of 2011 is an infringement of Art. 38(3) of the Treaty and contempt of Court.

1166 Kleis (2016), 174.

1167 Gathii (2011), 260.

1168 Oluoch (2009), 207.

1169 Gathii (2011), 259.

1170 Scharfenberg (2014), 277.
} 
diction on international crimes law may also distract from the Courts' jurisdiction on human rights. It appears thus advisable to refer to the ICC if there is a need for prosecution of international criminal law in this region.

In summary, the EACJ tries to override the limits set up by the politicians to offer access to citizens. This goal was finally achieved when the appellate division in the case Democratic Party v. The Secretary General of the EAC decided that the EACJ was, in the end, able to interpret the African Charter of Human and Peoples' Rights. It would, however, be a much greater sign for investors and people in this area if the Council would officially decide to extend the jurisdiction of the Court through the implementation of a new Protocol.

Since the governments did not appear too curious on the official extension of the jurisdiction of the EACJ it cannot be ruled out that a political retaliation of the partner States may happen, and thus potential litigants should not become too complacent. ${ }^{171}$

\subsection{The East African Legislative Assembly}

In addition, the establishment of a judiciary, Art. 9 of the EAC Treaty provides for the establishment of the Legislative Assembly of the East African Community (EALA). To determine the level of democratization in the EALA, the authorities have to be analyzed.

\subsubsection{The internal composition of the Legislative Assembly of the East African Community}

The EAC Treaty established an institution within the EAC regional agreement where political parties and thus also the people of the Member States are eligible to participate in the decision-making process of regional integration in East Africa. In line with Art. 50 of the Treaty, the East African Legislative Assembly (EALA) contains a total of 52 members and has its head office in Kampala, Uganda, as per Art. 2 of the EALA Rules of Procedure. The national assemblies of the EAC Member States elect 45 members. ${ }^{1172}$ The seven remaining EALA members are 'ex-officio' members that should be government ministers (or even assistant ministers) that have the responsibility to ensure regional cooperation in each of the Member States. ${ }^{1173}$ Added to those are the Secretary of the EAC and the counsel to the community who are also members of the EALA. ${ }^{1174}$

\footnotetext{
1171 Possi (2016).

1172 Musavengana (2011), 6.

1173 Oluoch (2009), 209.

${ }^{1174}$ Musavengana (2011), 6.
} 


\section{a) Election process of the members of the East African Legislative Assembly}

The Treaty states that ' $[\mathrm{t}]$ he National Assembly of each partner State shall elect, not from among its members, nine members to the Assembly, who shall represent as much as it is feasible, the various political parties represented in the National Assembly, shades of opinion, gender and other special interest groups in that partner State, in accordance with such procedure as the National Assembly of each partner State may determine. ${ }^{1175}$ The EAC Treaty does not provide any requirements on the election process of election of the respective members of the EALA. Thus, every Member State is obliged to create its own rules of procedure and guidelines. ${ }^{1176}$

The representatives of each Member State elected to the EALA thus have to be members of political parties but should not be members of the national parliaments. ${ }^{1177}$ This requirement of the Treaty raises the following issue: the representatives elected to the EALA do not have a direct popular mandate similar to that of a member of a national Parliament. Moreover, such a system significantly limits the influence of citizens, in contrast to the elected Members of Parliament who hold office by popular mandate.

Furthermore, only political parties who are members of the particular national assembly have the right to take part in the elections. Some political parties are thus excluded from the voting process of the EALA. For example, in Tanzania, there are three political parties that elect the members of the EALA: CCM, ${ }^{1178} \mathrm{CUF},{ }^{1179}$ and NCCR-M. ${ }^{1180}$ However, seven out of the nine representatives belong to the ruling party, CCM. Hence, the election process of the representatives of each EAC Member State is limited by the fact that EAC citizens cannot vote directly for represent-

1175 See: Art. 50(1) of the 1999 Treaty for the Establishment of the East African Community, see also: W. Kaahwa, 'The Institutional Framework of the EAC', in E. Ugirashebuja et al (eds), East African Community Law, Institutional, Substantive, Comparative EU Aspects (2017), 43, 49.

1176 F. Angila, Processes for Elections to The East African Legislative Assembly (2004), available at: http://library.fes.de/pdf-files/bueros/kenia/02119.pdf, (last visited: 2 September 2019).

1177 See: Art. 50 (1) of the 1999 Treaty for the Establishment of the East African Community.

1178 Chama Cha Mapinduzi (Party of the Revolution) is the dominant ruling party in Tanzania and the longest reigning ruling party in Africa. Since the restoration of the multi-party system, the CCM won the past five general elections in 1995, 2000, 2005, 2010 and 2015. Currently, the party holds 252 out of 366 seats in the National Assembly of Tanzania. See: Official Website of the Revolutionary Party of Tanzania: https:/www.britannica.com/topic/Revolutionary-Party-of-Tanzania, (last visited: 9 September 2019).

1179 Civic United Front is a liberal party in Tanzania. Although the party is nationally based, most of the supporters come from the Zanzibar islands of Unguja and Pemba. CUF is part of the opposition in Tanzania. Since the 2015 elections, the party holds 42 seats in the National Assembly of Tanzania. see: Official Website of Civic United Front, available at: https://cuftz.com/, (last visited: 9 September 2019).

1180 The National Convention for Construction and Reform-Mageuzi is an opposition party in Tanzania. Since the 2015 the party holds a single seat in the National Assembly of Tanzania see: A. Pallotti, 'Lost in transition? CCM and Tanzania's faltering Democratisation process', 35 Journal of Contemporary African Studies (2017), 544. 
atives of their choice. In practice, this means that the political party of a Member State with the greatest number of seats in the national parliament has the right to appoint most of the representatives for the EALA. ${ }^{1181}$ To resolve this issue, many experts claim a universal franchise to enhance the influence of the EAC citizens.

Art. 65 clarifies the relationship between the national assemblies and the EALA. Hence, 'the Council may be able to consider, in the exercise of its functions, the opinion of the general public in the partner States on matters relating to the achievement of the objectives of the Community as expressed through the debates of the elected members of their national assemblies [...].' Some debates of the EALA are also passed onto national assemblies. ${ }^{1182}$

\section{b) Issues regarding the elections of the second Assembly}

With regard to the elections of the second Assembly of the EALA, the developments in Kenya should be noted: in Kenya, the legal framework for the elections of the EALA is the Treaty for the Establishment of the East African Community Rules of 2001. ${ }^{1183}$ Thus, to be eligible to become a member of the EALA, the Treaty provides that the representative be a citizen of a Member State; be qualified to be elected as a member of the National Assembly of that Member State; not be holding office as Minister in a Member State; not be an officer in the service of the Community; and to have proven experience or interest in consolidating and furthering East African integration. ${ }^{1184}$

In context to the elections to the second Assembly, the EACJ became involved because of the case that was brought before it in 2006 - Prof Anyang'Nyong'o and Ten others v. Attorney General of the Republic of Kenya and Five Others ${ }^{185}$, which was of great public interest. The case came before the EACJ because of disagreements between the political parties ${ }^{1186}$ of Kenya being represented in the national parliament of Kenya and the individuals about to be appointed to the second Assembly of the EALA. The claimants doubted whether the election of the Kenyan representatives was in accordance with Art. 50 of the Treaty of the EAC. Art. 50 of the EAC Treaty states that 'the elected members shall, as much as feasible, be representative of specified groups' and furthermore clarified the qualifications for the Members of EALA to be eligible for the election and thus, the applicant argued that the Elections Act

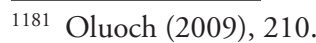

1182 Kaahwa (2017), 49.

1183 Oppong (2011b), 35.

1184 See: Art. 50(2) of the 1999 Treaty for the Establishment of the East African Community.

1185 Prof Anyang'Nyong'o and Ten others v. Attorney General of the Republic of Kenya and Five Others, Ref No. 1 of 2006, Judgment of 29 March 2007.

1186 For the second Assembly of EALA, the nine seats were supposed to be distributed as follows: in Uganda, the governing National Resistance Movement Party had seven seats whereas the remaining two seats went to the opposition; in Tanzania the governing Cha Cha Mapenduzi Party had eight seats, while in Kenya the governing NARC party was entitled to five seats and the remaining seats should have been shared among the opposition, see ibid., 4 et seq.
} 
of Kenya would not be inconsistency with the EAC Treaty. ${ }^{1187}$ The applicant argued that the elections of the representatives were void since there was no debate in the Kenyan Parliament.

The EACJ found that the Kenyan government did not elect the representatives of Kenya through voting and hence, the election was not held in accordance with Art. 50 of the Treaty of the EAC. ${ }^{1188}$ Furthermore, the Court found that the rules governing the election of the Kenyan parliament infringed Art. 50 of the Treaty since their representatives in the EALA were not elected through a vote. ${ }^{1189}$

The EACJ finally argued that the wording of 'election' in Art. 50 makes it very unlikely that the parties to the Treaty intended that a National Assembly would elect the representatives in the EALA by means other than a voting procedure. ${ }^{1190}$ Hence, in contrast to the opinion of the respondent, in this case, the Court found that the representatives to the EALA need to be elected with a ballot. ${ }^{1191}$ However, the Court argued that the claimants did not provide for locus standi and thus no course of action existed. The Court further found that for a litigant to possess locus standi he needs to '(1) have sufficient interest in the subject matter of the adjudication; and (2) be seeking a remedy in respect of a legal right, which has been infringed or violated.' ${ }^{1192}$ However, since Arts. 28-30 of the EAC Treaty do not assume a locus standi the EAC Court finally has a very broad range of litigants. The Court hereby stated that the Treaty 'confers on any person resident in Partner State the right to refer the specified matters to this Court for adjudication and as we have just said, by the same provision it creates a cause of action.' 1193

In March 2007, the EACJ ordered new elections of the EALA members in Kenya and thus confirmed its injunction against the swearing of the EALA members of Kenya.

The Court as consequence was criticized for overstepping its jurisdiction. Thus, amendments of Treaties were proposed in order to reduce the authority of the Court. They were adopted by the Heads of State and Government without prior consultation. Thus, the East African Law Society (EALS) under the provisions of Art. 30 of the Treaty, stating that any person who is a citizen of the EAC may refer for determination the legality of an Act or directive, argued that the amendments of the Treaty are inconsistent with procedural requirements of Art. 150 of the Treaty. The Authority did not allow the correct procedure of negotiation, which is pre-

\footnotetext{
$\overline{1187 \text { Gathii (2011), } 269 .}$.

1188 Oluoch (2009), 207.

1189 See: 'Nyong'o and Ten Others v. Attorney General of the Republic of Kenya, EAC Judgment Ref. No. 1/2006, at 37 and 43.

1190 Gathii (2011), 270.

1191 Scharfenberg (2014), 220 et seq.

1192 See: Nyong'o and Ten Others v. Attorney General of the Republic of Kenya, 22 et seq.

1193 Gathii (2011), 272.
} 
scribed by Art. 150 of the Treaty. The Court found ${ }^{1194}$ that Arts. 5(3)(g), 7(1)(a) and 150 of the Treaty have been violated since the civil society could not participate in the amendment process. However, the Court did not declare the amendments to be invalid stating: '[T]he infringement was not a conscious one [...] after this clarification of the law on the matter the infringement is not likely to recur [and] [...] not all the resultant amendments are incompatible with Treaty objectives [...].'1195

\section{c) The internal structure of the East African Legislative Assembly}

Currently, the EALA has several Committees covering the following topics: The House Business Committee; the Accounts Committee; the Committee on Legal, Rules and Privileges; the Committee on Agriculture, Tourism and Natural Resources; the Committee on Regional Affairs and Conflict Resolution; the Committee on Communication, Trade and Investment and the Committee on General Purpose. ${ }^{1196}$ The purpose of the Committees is to control the implementation of the various provisions of the Treaty. As the Committees make up the technical arm of the EALA and execute the majority of the EALA's work, they are pivotal in providing input in the final decisions of the EALA. ${ }^{1197}$ Besides that, the EALA provides for a Speaker who shall preside over the proceedings of the Assembly and for a Clerk and other officers, as per Art. 48.

\subsubsection{The mandate of the East African Legislative Assembly}

The EALA has great significance regarding the furtherance of the objectives of the Community and hence has several functions in legislative, representative and oversight matters. According to Art. 49 of the Treaty of EAC, the EALA inter alia shall be the legislative organ of the Community, debate and approve the budget of the Community and establish any Committee or Committees deemed necessary.

The Treaty of the EAC further assigns the following functions to the EALA: Art. 49(2d) outlines the Assembly's mandate to debate all matters pertaining to the Community and to make recommendations to the Council as it may deem necessary for the implementation of the Treaty. However, there is no obligation by the Council to consider the recommendations. ${ }^{1198}$

${ }^{1194}$ East African Law Society and Others v. Attorney General of the Republic of Kenya, EAC Judgment Ref. No. 3/2007, Judgment of 1 September 2008.

1195 Ibid., paras 43-4.

1196 See: Rule 78 of the 2001 East African Legislative Assembly Rules of Procedure.

1197 See: Rules 79 to 81 of the 2001 East African Legislative Assembly Rules of Procedure.

1198 Oluoch (2009), 209. 
The Treaty also provides that EAC legislation is done through the passage of bills. ${ }^{1199}$ In general, members of the Assembly have the right to introduce bills. ${ }^{1200} \mathrm{To}$ pass a bill, a majority vote of the representatives present at the Assembly is needed. If a bill is passed by the EALA, the Heads of States and Governments have to approve it after which it becomes an Act of the Community. ${ }^{1201}$

The extension of the mandate of the EALA was disputed before the EACJ in the case Calist Mwatela, Lydia Wanyoto Mutende and Isaac Abraham Sepetu v. East African Community which was submitted by the above mentioned Members of the East African Legislative Assembly. ${ }^{1202}$

In 2004, there were four bills being introduced in the parliament. The introduced bills were the following: The East African Trade Negotiations Bill, East African Community Budget Bill, East African Immunities and Privileges Bill and the Inter-University Council for East Africa Bill.

After a long dispute regarding the competences between the Council and the EALA, the applicants asked the Court to decide whether the occupation of the Sectoral Council and the meeting with it was lawful.

Further, the applicants asked the Court to carry out a legal assessment of the introduced bills as well as the relation between the EALA and Council in terms of legislative procedures. ${ }^{1203}$

The Court found that the composition of the Sectoral Council did not comply with requirements set out in Art. 13 and 14 of the EAC Treaty, stating that only members of the Council that hold the position as a national minister at the same time is allowed to represent a Member State in the Sectoral Council. Thus, the representatives of Uganda and Kenya did comply with those requirements. The posted representatives of Tanzania did not comply with the provisions. As consequence, the Court stated that '[it] therefore ha[s] no hesitation in reiterating that the meeting of $14^{\text {th }}$ to $16^{\text {th }}$ September 2005 was not a lawful meeting of a Sectorial Committee and that the decisions handed down in respect of the two Bills was not valid decision of the Sectoral Council.' ${ }^{1204}$

Furthermore, the Court issued a ruling stating that the EALA, as well as the Council, is able to introduce legislative initiatives. Taking into consideration Art. 59(1) of the Treaty, the members of the EALA are allowed to introduce legislative initiatives into parliament. Moreover, the Council also has the right on initiative (Art. 14(3) of the Treaty) but on the same side is not allowed to withdraw initiatives

\footnotetext{
1199 See: Art. 62(1) of the 1999 Treaty for the Establishment of the East African Community.

1200 See: Art. 59 of the 1999 Treaty for the Establishment of the East African Community.

1201 Kaahwa (2017), 49.

1202 Calist Mwatela, Lydia Wanyoto Mutende and Isaac Abraham Sepetu v. East African Community, Judgment Ref. No 1/2005, Judgment of 3 October 2006.

1203 'Nyong'o and Ten Others v. Attorney General of the Republic of Kenya, EAC Judgment Ref. No. $1 / 2006,14$ et seq.

1204 Scharfenberg (2014), 211 et seq.
} 
issued by EALA members. A withdrawal of legislative initiative from the midst of the EALA is only possible under the provisions of Art. 34(1) of the Rules of Procedure of EALA. ${ }^{1205}$

With regard to the third issue - the relationship between the Council and the EALA the Court stated the following: The Court considered, that it was not possible for the Council to limit the legislative initiative with its decision of the 24 November 2004. At the same time, the Court stated that Art. 59(1) of the Treaty limits the competencies as follows since it reads: 'Art. 59(1) prohibits the introduction of any motion in the Assembly which does not relate to the functions of the Community or does not relate to a matter with respect to which an Act of the Community can be enacted. ${ }^{1206}$ Art. 49(2) of the Treaty though limits the legislative competences of the EALA, while excluding some sectors ${ }^{1207}$ from its competence.

The Court further found that since the four bills are still under consultation and will be decided on in future, the Court is not competent to prove if the regulation is covered by the competencies set out in Art 59(1). ${ }^{1208}$ However, the Court stated the following:

Any matter which is still under the exclusive sovereignty of the Partner States is beyond the legislative competence of the Community. The Assembly is creature of the Treaty like the other Organs of the Community and such Organ can only have competence on matters conferred upon by the Treaty. The Assembly has no power to legislate on matters on which the Partner States have not surrendered sovereignty. ${ }^{1209}$

Until today, the EALA already passed a number of important bills such as the East African Community Emblems Act of 2003, the East African Community Interpretation Act of 2003 as well as institutional development laws such as the East African Legislative Assembly (Powers and Privileges) Act of 2003, the Summit (Delegation

1205 Art. 34(1) of the EALA Rules of Procedure reads: 'A motion or an amendment to the motion may be withdrawn at the request of the mover by leave of the House or Committee before the question is put.'

1206 See: Mwatela, Mutende and Sepetu v. East African Community, Taxation Cause No. 1 of 2006, Judgment of 1 November 2007, 14 et seq.

1207 Art. 56(2) of the EAC reads as follows: The Assembly shall not a) proceed on any bill, including an amendment to any Bill, that, in the opinion of the person presiding, makes provision for any of the following purposes: (i) for the imposition of any charge upon any fund of the Community; (ii) for the payment, issue or withdrawal from any fund of the Community of any moneys not charged thereon or the increase in the amount of any such payment, issue or withdrawal; (iii) for the remission of any debt due to the Community; or (b) proceed upon any motion, including any amendment to a motion, the effect of which, in the opinion of the person presiding, would be to make provision for any of the said purposes.

1208 Scharfenberg (2014), 216.

1209 See: Mwatela, Mutende and Sepetu vs. East African Community, Taxation Cause No. 1 of 2006, 22 et seq. 
of Powers and Functions) Act of 2007, the Inter-University Council for East Africa Act of 2008, the East African Legislative Assembly Members Election Act of 2011 and the East African Community Parliamentary Institute Act, 2012. ${ }^{1210}$

However, to ensure effective and successful regional integration, the EAC may be forced to resolve this issue, since successful regional integration can only take place with the full participation of EAC citizens. ${ }^{1211}$

Currently, representatives are attempting to create such a link by doing tours through the EAC Member States, e.g. in 2014, members of the EALA did a tour through Kenya, which was strongly supported by the Kenyan government. The tour aimed to inter alia recognize the diversity of the populations and to evaluate the development initiatives being implemented in the area. The tour was also aimed at affording an opportunity to members of the EALA to 'interact directly with citizens and hear their views, aspirations and fears on the integration process.' 1212

MP Peter Mathuki remarked that:

Art. 5 of the Treaty envisages a people-centred integration. In this regard, we must enhance involvement of the people in deciding on the matters of the Community. It is important for the Assembly to be in step with the needs of the people through a structured interface and the working tour is one such avenue. ${ }^{1213}$

Besides that, NGOs only have observer status. Furthermore, the regulations for civil society organizations to be recognized as partners in the EAC framework are very strict. For example, the domestic legislation ${ }^{1214}$ of Tanzania still limits the influence of Tanzanian civil society organizations, since they are inter alia not allowed to have an impact on politics.

\subsubsection{The proposal of a Human and Peoples' Rights Bill}

In April 2012, the EALA passed the EAC Human Rights Bill. It was further passed onto the EAC Summit. However, as far as is apparent, the Summit has not, thus far, approved the Bill.

The Memorandum of the Bill declares that:

the objective of [the] Bill is to establish an East African Community human rights regime; give effect to the provisions of the Treaty for the Establishment of the East African Community on human and people's rights; and to establish a mechanism for the recognition, promotion and protection of human

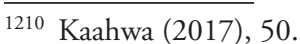

1211 Angila (2004).

1212 EALA, 'EALA Set to Visit 5 Countries as It Starts Kenya Tour', available at: http://www.eala.org/ new/index.php/media-centre/press-releases/632-eala-set-to-visit-5-counties-as-it-starts-kenyatour, (last visited: 1 July 2016).

1213 Ibid.

1214 See: The 2002 Non-Governmental Organization Act 24 of Tanzania.
} 
and people's rights in accordance with the provisions of the African Charter on Human and Peoples Rights. The Bill also seeks to foster the process of deepening and widening integration by guaranteeing human and people's rights in the social, economic and political spheres.

Similar to the African Charter on Human and Peoples' Rights, the proposed Bill includes the protection of a broad catalogue of fundamental rights including socio-economic rights.

Besides that, Art. 49(1) of the Bill includes the provision, the Court has jurisdiction to 'hear applications for redress for violation of a right or a fundamental freedom under this Act.' Furthermore, Art. 49(2) states that National Parliaments should issue legislation to give 'original jurisdiction in appropriate cases to subordinate courts to hear applications for redress for contravention of this Act.'

The transformation of this proposal would be a milestone regarding the protection of human and peoples' rights in the East African region. The Bill as it is proposed would, however, lead to a circumvention of Art. 27(2) of the EAC which allows the Council to expand the jurisdiction of the Court. Thus, there is much doubt about a speedy ratification by the EAC Summit. ${ }^{1215}$

Additionally, the EALA is not yet taken seriously as an institution. According to several opinions, the EALA is 'a political dumping ground, a safe haven for failed national political careers or a reservoir for rewarding political supporters and sycophants, as politicians who failed in their domestic political careers are moved to the EALA. ${ }^{1216}$

In 2002 a member of the East African Legislative Assembly stated:

We will take our duties seriously, we will be aware of where we are in the different countries in developing the new responsibility for our own development, not only for our own transformation, but also for the respect of the rule of law and the observance of Human Rights. ${ }^{1217}$

\subsection{Conclusion on the East African Parliament}

Regarding the East African Legislative Assembly, some operational as well as structural issues limit the level of the protection of the rule of law and the therewith-connected level of democracy.

Since every Member State has the same number of representatives in the EALA, the population of each country is not represented adequately.

\footnotetext{
1215 Possi (2013), 183.

1216 Oluoch (2009), 210.

1217 Gathii (2013), 261.
} 
Furthermore, the Treaty of the EAC does not provide for an adequate link between the EAC and the EAC citizens. One reason is that the EALA has not yet attempted to approve any legislation with the objective of providing for direct elections. The EALA further needs to ensure that EAC citizens are aware of its work and existence.

Besides that, the relationship between the EACJ and the Council with respect to the enacting of bills is observed with much displeasure: there is still no clarity 'as to who, between elected members of the Assembly and the Council, has the power to initiate and present what kind of bills to the Assembly.' ${ }^{1218}$ However, the Council was criticized for the very slow initiation of Bills to the EALA. ${ }^{1219}$ To stem the influence of the Council in this regard, the EACJ decided in Calist Andrew Mwatela and Two Others $v$. The East African Community that the Council does not have any authority to remove pending bills tabled by private citizens from the Assembly. ${ }^{1220}$ Furthermore, the EACJ stated in its finding, that the Council has no powers to influence the decisions of the Assembly, taking into consideration Art. 14 and 16 of the Treaty of the EAC. ${ }^{1221}$ However, due to a lack of information regarding the work and function of the Assembly, the public has not yet criticized the institutional issues of the Assembly. ${ }^{1222}$

The introduction of the Bill of Human and Peoples' Rights, as well as the push towards the extension of the jurisdiction of the EACJ and the establishment of human rights standards within the region of East Africa, show that the EALA tries to give effect to such ambitions as presented in the above statement. Since the Summit always needs to approve the Bills or resolutions of the EALA, the success of this institution remains highly dependent on the political will of the leaders within the region.

In summary, EAC at least introduced a real legislative forum in its Treaty, however, the Authority and the governments of Member States nevertheless exert far too much influence e.g. in the adoption of bills and in the representation in the EALA by political parties and private persons.

\subsection{Final Conclusion on the East African Community}

The EAC is the smallest REC within Africa but however, is the best developed REC within the continent taking into consideration the achievement of economic targets such as the establishment of a Common Market in 2010 and the elimination of tar-

\footnotetext{
1218 Ibid.

1219 Kaahwa (2017), 50 et seq.

1220 See: Calist Andrew Mwatela and Two Other v. EAC, Taxation Cause No. 1 of 2006, Judgment of 1 November 2007, 15.

1221 Ibid, 17.

1222 Oluoch (2009), 211.
} 
iffs within the region. ${ }^{1223}$ Although a significant part of the population in the EAC area still lives in poverty, the region is described as one of the 'world's fastest growing economies.' ${ }^{1224}$ Within EAC, the respective Member States generally provide for fairly efficient labor markets. Further, the financial institutions are rather well-developed, and they provide for innovative ideas. ${ }^{1225}$

The five EAC Member States, Burundi, Kenya, Rwanda, Tanzania and Uganda are mindful that by putting together their economic potential and human and physical resources, they are in a powerful position to realize their development objectives. Hence, the EAC demonstrates, in comparison with other African regional areas, 'the most ambitious political and economic programs. ${ }^{1226}$

With regard to human rights protection and the protection of the rule of law, the EAC is quite developed. The EAC provides for a functioning Court - which should however be working on permanent basis and not as ad hoc institution. The implementation of the Court's decision within the affected Member States of EAC is similar to the non-recognition is unknown. The change of occupation of the Council which resulted in the judgment of Mwatela, Mutede and Sepetu v. East African Community leads to the impression that the judgments of the Court fall on understanding ears. ${ }^{1227}$ Attempts were made to extend the jurisdiction of the EACJ, however under the provisions of the Treaty the Court is not yet empowered to hear human rights related cases. However, with the judgment of Democratic Party v. Secretary General of the East African Community the Court again declared that it would be competent to hear human rights cases. Similar to the ECOWAS Court, the EAC recently issued a ruling ${ }^{1228}$ involving journalists. The Court found that the Burundian Law obliging journalists to reveal 'their sources of information before the competent authorities in situations where the information relates to offences against State security, public order, State defense secrets and against the moral and physical integrity of one or more persons is in violation of Articles 6(d) and 7(2) of the Treaty. ${ }^{\prime 229}$ This judgment of the EACJ, involving the freedom of media and press for the first time, thus sets a sign for the importance of their independent work not only for journalists but to journalists within the whole area.

Together, with the intention of Members of the EALA to establish a Bill on $\mathrm{Hu}$ man Rights, the protection of human rights and the rule of law are of great importance within the region of East Africa. The impression becomes reflected through the impressive economic growth within the region.

\footnotetext{
$\overline{1223}$ Lehmann (2003), 242.

${ }^{1224}$ L. Wanyama, 'The Economic Diplomacy of Kenya's Regional Interests', SAIIA Occasional Paper No 137 (2013), 11.

1225 Viljoen (1999), 205.

1226 Kleis (2016), 88.

1227 Scharfenberg (2014), 277.

1228 Burundian Journalists Union v. The Attorney General of the Republic of Burundi, App. No. 7 of 2013, Judgment of 15 May 2015.

1229 Ibid., para 123.
} 


\section{Chapter 7: \\ Common Market of Eastern and Southern Africa (COMESA)}

\subsection{Introduction}

The Common Market for Eastern and Southern Africa (COMESA), covering regions of eastern and southern Africa, consists of 19 African countries, which are Burundi, Comoros, Democratic Republic of Congo, Djibouti, Egypt, Eritrea, Ethiopia, Kenya, Libya, Madagascar, Malawi, Mauritius, Rwanda, Seychelles, Sudan, Swaziland, Uganda, Zambia and Zimbabwe. The area of COMESA encompasses a population of about 400 million people and covers about 13 million square kilometers. ${ }^{1230}$ With a total export/import value of US\$ 309 billion, COMESA is one of the major economic zones within the African continent. ${ }^{1231}$ The COMESA Treaty establishing the RTA was signed in November 1993. ${ }^{1232}$

\footnotetext{
${ }^{1230}$ P. Steyn, 'Africa's First Supranational Competition Authority Commences Operations: Issues Arising from the New COMESA Merger Control Regime', 9 Competition International Law Journal (2013), 137.

1231 Dirar (2010), 223.

1232 Scharfenberg (2014), 282.
} 


\subsection{Historical background of the Common Market for Eastern and Southern Africa}

The merger of regions within eastern and southern African begun five decades ago.

In 1966 ten countries of Eastern and Southern Africa - namely Burundi, Ethiopia, Kenya, Madagascar, Malawi, Mauritius, Rwanda, Somalia, Tanzania and Zambia - started negotiations and put forward proposals for a treaty for future economic co-operation. ${ }^{1233}$

The process of establishment of the Common Market for Eastern and Southern African started in March 1977, when the $4^{\text {th }}$ Conference of Ministers of the United Nations Economic Commission for Africa adopted the so-called action program in order to implement the 'New International Economic Order'. The paper inter alia provided for several guidelines concerning regional and subregional integration. The paper outlined that the most sufficient development of national economies would only be achieved through the push towards a multinational process. Soon after the endorsement of the paper by the African Heads of State and Government Summit in June 1977, the $4^{\text {th }}$ Conference of the UN Economic Commission for Africa (ECA) and $13^{\text {th }}$ Session of the Commission decided to establish ECA Multinational Programming and Operational Centres (MULPOCs) within subregional levels in sub-Saharan Africa. The objective of the MULPOCs was to promote economic co-operation among African countries on subregional levels. The ultimate goal was to create subregional economic co-operation agreements in order to create subregional common markets. ${ }^{1234}$

One of such MULPOCs encompassing the subregions of Eastern and Southern African, was based in Lusaka. In 1977 following the establishment of the MULPOC, the Council of Ministers adopted its first working program, stating the promotion of subregional economic co-operation. ${ }^{1235}$

One year later, in 1978, a meeting of Ministers of Trade, Finance and Planning of MULPOC took place to adopt the Lusaka Declaration of Intent and Commitment to the establishment of a Preferential Trade Area for Eastern and Southern Africa (PTA), which aimed to establish a common market within approximately 10 years. ${ }^{1236}$ The establishment of a Common Market intended to introduce the integration of the markets and to create free trade areas. The negotiations on the Draft Treaty concluded with a Second and Third Extra-ordinary Conferences of Ministers of Trade, Finance and Planning in May and October 1981, which aimed to discuss the remaining differences and to approve the Draft Treaty establishing PTA. ${ }^{1237}$

\footnotetext{
1233 J. van Weijen, 'COMESA, free trade area by October 2000', 24 International Trade Law \& Regulation (2000), 153.

${ }^{1234}$ M. Gondwe, 'From PTA to COMESA; The Quest for Sub-Regional Economic Integration in Eastern and Southern Africa', 6 African Yearbook of International Law (1998), 3, 4 et seq.

1235 Ibid.

1236 Scharfenberg (2014), 281.

1237 Gondwe (1998), 5 et seq.
} 
In 1981, the Treaty establishing the PTA was finally signed by a Conference of Heads of States at Lusaka and came into force due to sufficient ratifications on 30 September in $1982 .{ }^{1238}$

The PTA represented a regional integration scheme whose objects included to 'create trade within the Southern and Eastern Africa region (i.e. between Member States) and to divert trade away from the then apartheid South Africa.' ${ }^{1239}$ A couple of years later, on 5 November 1993, the Treaty of COMESA was signed at Kampala, Uganda. As the reason for the transformation from a PTA into COMESA was announced that the ' $[i]$ ntegration scheme has now progressed from a preferential trade area into a common market. ${ }^{1240}$ This process was followed by the transformation of the free trade area into a common market of countries of Southern and Eastern Africa. On 5 December 1994 the COMESA Treaty was ratified in Lilongwe, Malawi. ${ }^{1241}$

According to the integration scheme being adopted by COMESA, the last step of economic integration is supposed to be the creation of an economic community. The COMESA Treaty, however, does not explicitly provide definitions for a common market, an economic community or a preferential area and thus does not distinguish between the three phases. ${ }^{1242}$ In 2000, COMESA planned to remove all internal trade barriers to create a free trade area encompassing the whole region. However, thus far this objective has still been implemented only partially. ${ }^{1243}$ So far only 14 Member States have joined the FTA, but some countries, such as Ethiopia, are afraid to put its domestic industry at a disadvantage by joining the FTA. ${ }^{1244}$

The implementation of a common external tariff structure with regard to third parties was also planned. This process was problematic as some countries were afraid of losing income if they did not apply their own tariff regulations throughout. ${ }^{1245}$ To prepare for the launching of a customs union, the Council of Ministers implemented several activities and programs being necessary for the creation of such a union. Finally, in 2009 - five years after the proposed date - the customs union of COMESA was launched at the $11^{\text {th }}$ Summit of Heads of States and Governments. ${ }^{1246}$ Since the COMESA unites many countries of very different levels of development, the princi-

\footnotetext{
1238 Viljoen (2007), 491 et seq.

1239 K.K. Mwenda, 'Legal Aspects of Regional Integration: Comesa and SADC on the Regulation of Foreign Investment in Southern and Eastern Africa', 9 Afr J Int'l \& Comp L (1997), 324, 326. 1240 Ibid.

${ }^{1241}$ M. Oduor, 'Resolving Trade Disputes in Africa: Choosing between Multilateralism and Regionalism: The case of COMESA and WTO, 13 Journal of International Comparative Law (2005), $177,189$.

1242 Mwenda (1997), 326.

1243 Viljoen (2007), 492

1244 Lehmann (2003), 268.

1245 Oduor (2005), 190.

1246 I. Shinyeka \& L. Othieno, 'Prospects and Challenges in the formation of the COMESA-EAC and SADC Tripartite Free Trade Area', Africa Portal (1 November 2011), available at: https:// www.africaportal.org/publications/prospects-and-challenges-in-the-formation-of-the-comesaeac-and-sadc-tripartite-free-trade-area, (last visited: 3 April 2016).
} 
ple of 'variable geometry' was introduced. Thus, in order to speed up the process of integration, some Member States may implement the steps towards full regional integration faster than other Member States. In addition, all Member States introduced a system of sanctions aiming to achieve a speedy progress of integration. ${ }^{1247}$

Currently, most Member States of COMESA are members of at least one more REC. This phenomenon is also called the 'spaghetti bowl' problem. In order to achieve greater integration results Member States that are member to more than one REC should make a policy choice. The first option would be to withdraw from multiple memberships. This option however could lead to minimization of the market size of the withdrawing country.

Another option to solve this issue would be the merger of the COMESA, SADC as well as the EAC. The merger of these three blocs would require much political will. One step towards the merger of the three blocs was the establishment of the Tripartite Free Trade Area (TFTA).

On 10 June 2015, the Agreement regarding the set-up of the Tripartite Free Trade Area was eventually signed at Sharm-el-Sheikh, Egypt. ${ }^{1248}$ The aim of the TFTA is to consolidate together all Member States of COMESA, SADC and the EAC. Only Libya and Eritrea did not sign the Agreement. ${ }^{1249}$ The countries involved represent almost 48 per cent of the members of the African Union and a population of nearly 632 million citizens. The TFTA is still confronted with several issues, such as tariff liberalization schedules, exemptions, and Rules of Origin. ${ }^{1250}$

According to the Agreement, the regional integration scheme is based on three pillars, firstly infrastructure development, secondly market integration and lastly industrial development. Several programs have been initiated towards the successful realization of these three pillars. ${ }^{1251}$ The Summit decided to implement a first range of programs regarding industrial development focusing on situational analysis on industrial trends and potential and regional value chair analysis. ${ }^{1252}$

$\overline{1247 \text { Gathii (2011), } 272 .}$

1248 Luke \& Mabuza (2015).

1249 SADC-EAC-COMESA Tripartite Free Trade Area Legal Texts and Policy Documents, available at: https://www.tralac.org/resources/by-region/comesa-eac-sadc-tripartite-fta.html, (last visited: 12 July 2016).

1250 S. Andriamananjara, 'Africa in Focus: Understanding the importance of the Tripartite Free Trade Area', Brookings (17 June 2015), available at: https://www.brookings.edu/2015/06/17/understanding -the-importance-of-the-tripartite-free-trade-area/, (last visited: 12 July 2016).

1251 J. P. Folfas \& J. Garlińska-Bielawska, 'Can the Tripartite Free Trade Area (TFTA) Agreement Become a Breakthrough Arrangement in Regional Integration on the African Continent?' (January 2018), available at: https://www.researchgate.net/profile/Pawel_Folfas/publication/323527234_ Czy_Porozumienie_Tripartit e_Free_Trade_Area_TFTA_moze_stac_sie_przelomowe_w_ procesie_integracji_regionalnej_na_kontynencie_afrykanskim/links/5aa0f2cf0f7e9badd9aac3a8/ Czy-Porozumienie-Tripartite-Free-Trade-Area-TFTA-moze-stac-sie-przelomowe-w-procesieintegracji-regionalnej-na-kontynencie-afrykanskim.pdf, (last visited: 14 August 2018).

1252 G. Erasmus \& T. Hertzenberg, 'The Tripartite Free Trade Area, towards a New African Integration Paradigm?', available at: https://www.tralac.org/publications/article/4658-the- 
Art. 10 of the TFTA Agreement, as well as Annex 3, stipulate the harmonization of the three previous agreements of SADC, EAC and COMESA into a single mechanism. ${ }^{1253}$ The implementation would be a risky and protracted process and would demand much political will of all the governments of the Member States. ${ }^{1254}$ The Tripartite Area, according to its Treaty shall provide for a Tripartite Summit, a Tripartite Council of Ministers, the Tripartite Sectoral Ministerial Committees, the Tripartite Committee of Senior Officials as well as the Tripartite Trade Negotiation Forum. ${ }^{1255}$

\subsection{Objectives of the Common Market for Eastern and Southern Africa}

Having outlined the historical background describing the transformation of the Preferential Free Trade Area into a Common Market, the study will further outline the objectives of the Common Market.

Art. 3(d) of the COMESA Treaty sets out several objectives: one of the aims and objectives of the COMESA is 'to co-operate in the promotion of peace, security and stability among Member States in order to enhance economic development in the region.' Amongst the most important objectives of COMESA is the facilitation of trade among its members and the improvement of security, political development and resource utilization. ${ }^{1256}$ With regard to the COMESA Treaty, another main principle speaks to the 'equality and inter-dependence of the Member States'. ${ }^{1257}$ Furthermore, COMESA further aims to contribute towards the establishment and the objectives of the AEC, as per Art. 3(f).

To achieve its aims and objectives, COMESA has established several programs and activities concerning trade liberalization and facilitation, monetary integration and infrastructure development. ${ }^{1258}$ Art. 3 of the Treaty expounds its main focus as the formation of a large economic and trading unit on the African continent, with the necessary competencies to overcome some of the 'barriers that are faced by individual States.' ${ }^{259}$ Consequently, Art. 3 of the COMESA Treaty inter alia states, that the objectives of the Common Market shall be 'to attain sustainable growth and

tripartite-free-trade-area-towards-a-new-african-integration-paradigm.html, (last visited: 14 August 2018).

1253 Luke \& Mabuza (2015).

1254 Andriamananjara (2015).

1255 Scharfenberg (2014), 293.

1256 Oduor (2005), 184.

1257 See: Art. 6(a) of the Treaty Establishing the Common Market of Eastern and Southern Africa (COMESA)

1258 S. Olofin, 'A survey of the capacity needs of Africa's Regional Economic Communities', Africa Platform (1 July 2008), available at: http://www.africa-platform.org/resources/survey-capacityneeds-africas-regional-economic-communities-executive-summary, (last visited: 8 August 2016).

1259 Oduor (2005), 179. 
development of the Member States by promoting a more balanced and harmonious developments of its production and marketing structures' and 'to promote joint development in all fields of economic activity and the joint adoption of macroeconomic policies and programmes to raise the standard of living of its peoples and to foster closer relations among its Member States'.

Besides trade-law related objectives, Art. 6(e) of the COMESA Treaty refers to the principle of recognition promotion as well as the protection of human and people's rights in accordance with the provisions set out in the African Charter of Human and Peoples' Rights. This provision shows that the COMESA, in general, recognizes the existence of the African Charter but that does not mean that the latter would be protected through COMESA. In order to ensure the implementation of the objective of equality, the Federation of National Associations of Women in Business (FEMCOM) was established in 1993, which serves as a forum for discussing ideas and experiences among women entrepreneurs of the subregion. FEMCOM is working on programs that shall ensure the involvement of women in development and trade. ${ }^{1260}$

\subsection{Organs of the Common Market of Eastern and Southern Africa (COMESA)}

In order to achieve its objectives, as set out in the COMESA Treaty, the Common Market provides for similar institutions as the other subregional trade areas that form part of this thesis but also provides some institutional differences, in accordance with Art. 7 COMESA Treaty these are: the Authority, the Council, the Court of Justice, the Committee of Governors of Central Banks, the Intergovernmental Committee, Technical Committees, the Secretariat, and the Consultative Committee.

Just like the other subregional trade communities, the decision-making organ is the Authority, which is composed of the Heads of State and Government. The Authority is responsible for the general policy and direction of COMESA, as per Art. 8(2). Besides that, the Council of Ministers is authorized to give recommendations to the Authority and to ensure the development of the Common Market and to make regulations and to take decisions in accordance with the COMESA Treaty, pursuant to Art. 9(2). The Council is composed of such Ministers as may be designated by the respective Member State, in line with Art. 9(1). In accordance with Art. 11 all regulations and directives issued by the Council shall be binding to the Member States.

Art. 13(1) of the COMESA Treaty states that the Committee of Governors of Central Banks consists of governors of respective monetary institutions of the COMESA Member States. The Committee shall be inter alia competent to develop programs and other action plans relating to monetary cooperation and finance, as per Art. 13(2). Besides the Committee of Governors of Central Banks, the Intergovernmental Com-

${ }^{1260}$ Ruppel (2009), 286 et seq. 
mittee shall be responsible to ensure the development of programs in all fields of financial and monetary cooperation. The Intergovernmental Committee shall consist of Permanent and Principal Secretaries, as stated under Art. 14(1). Art. 15 provides the establishment of several Technical Committees, which shall be composed designated representatives of the Member States. The Technical Committees shall develop programs relating to their sector and to ensure their implementation.

Art. 17 stipulates the establishment of a Secretariat, which is enabled to support the other institutions with their work and which is headed by a Secretary General. The Consultative Committee shall provide a link between business groups and the institutions of the Common Market, in line with Art. 18(3). Lastly, the COMESA Court of Justice has jurisdiction all matters which are considered pursuant to the Treaty, in accordance with Art. 23(1).

\subsection{The Court of Justice of the Common Market for Eastern and Southern Africa}

The Treaty of COMESA determines the COMESA Court of Justice (CCJ) as the judiciary organ. The Court may, similar to other subregional Courts of the continent, contribute towards the realization of human rights through its jurisdiction.

\subsubsection{Introduction}

As the Common Market provides for a legal system, an 'effective system of judicial safeguards' is needed in the case of the law being challenged or if it needs to be applied. ${ }^{1261}$ Hence, the Treaty of COMESA provides for the establishment of the Court of Justice of COMESA to be the permanent Court. ${ }^{1262}$ After a new host agreement was signed, the permanent seat of the Court was assigned to Khartoum, capital of Sudan. ${ }^{1263}$

The CCJ was established when the COMESA Treaty was adopted in 1994. Art. 7 of the Treaty declares the Court to be an organ fully incorporated into the COMESA framework. ${ }^{1264}$ The CCJ is intended to deal with all disputes arising under either the COMESA Treaty or its several constituent agreements. ${ }^{1265}$

The Court of the PTA was the precursor of the COMESA Court. Pursuant to Art. 10 I of the PTA agreement, the PTA Court, in contrast to the COMESA Court, was competent to ensure the faultless application of an interpretation of the regulations set out in the Agreement of the Preferential Trade Area of the Common Market for Eastern and Southern Africa. However, until its dissolution, the Court

1261 COMESA Court of Justice; Medium Term Strategic plan, 2008-2010, 11.

1262 Oduor (2005), 201.

1263 Lehmann (2003), 265.

1264 See: COMESA Court of Justice, Medium Term Strategic Plan, 2008-2010, 1.

1265 Oduor (2005), 200. 
has never received any cases. In practice, arising disputes have been solved in informal negotiations or through the involvement of the Secretary General. ${ }^{1266}$ In addition, Art. 40 of the PTA Treaty stated that only disputes that arose between PTA Member States were eligible to fall under the jurisdiction of the PTA Tribunal. Thus, individuals or NGOs did not have access to that Court. However, an arbitration center in order to solve disputes concerning trade in Djibouti was eligible to receive claims of private persons. The arbitration center is still operating nowadays. ${ }^{1267}$

The CCJ was created in order to support COMESA's objective of regional integration; it is also pivotal to the success of COMESA by ensuring 'certainty and predictability in the Common Market Law.' ${ }^{1268}$ The Court assumes jurisdiction of all judicial bodies ${ }^{1269}$ that had been created during the existence of the PTA). ${ }^{1270} \mathrm{Ex}$ ercising its powers under Art. 38 of the Treaty, the Court of Justice has implemented the Rules of the Court of Justice. Furthermore, the CCJ has been given the objective to 'prevent inconsistency in the interpretation and application of the Treaty by ensuring that Member States do not interpret and apply its provisions in isolation from each other.' ${ }^{1271}$

\section{a) The internal Structure of the COMESA Court of Justice}

A functioning structure of the African Court is an important requirement for ensuring an effective judicature in the region.

The jurisdiction of the CCJ stretches over many diverse countries with fundamentally different domestic laws, such as civil law, Islamic law and common law. ${ }^{1272}$ At the time of its institution, the CCJ was only meant to be a 'one-stop-shop dispute resolution mechanism. ${ }^{1273}$ The review of a claim was done only in cases where one of the involved parties could show that new and decisive evidence has been found

\footnotetext{
1266 Lehmann (2003), 260.

1267 See: Art. 3 (a) and (b) of the 1994 Treaty Establishing the Common Market of Eastern and Southern Africa.

1268 D. Kayihura, 'Parallel jurisdiction of courts and tribunals: the COMESA Court of Justice perspective', 36 Commonwealth Law Bulletin (2010), 583.

1269 The previous judicial bodies have been: the PTA Tribunal that had to ensure the proper interpretation of the Treaty and also had to adjudicate in disputes between member states. Additionally, the PTA Administrative Appeals Board was launched to adjudicate in disputes between the PTA and its staff. Furthermore, the PTA Centre for Commercial Arbitration was established to facilitate international arbitration and conciliation of private and commercial disputes, see: COMESA: Establishment of the Court, available at: http://comesacourt.org/establishment/, (last visited: 5 September 2018).

1270 Scharfenberg (2014), 283.

1271 Kayihura (2010), 584.

1272 Ibid.

1273 See: Art. 31(3) of the 1994 Treaty Establishing the Common Market of Eastern and Southern Africa.
} 
since the original Court decision. ${ }^{1274}$ Nevertheless, due to an amendment, the CCJ is now comprised of two different divisions: the Appellate Court headed by the President of the Court and the Court of First Instance headed by the Principal Judge.

The Registrar of the COMESA Court is responsible for the several day-to-day operations under the supervision of the Judge President. Additionally, registry and administrative staff assist the Registrar. ${ }^{1275}$

At present, the Court is composed of twelve judges, seven of whom belong to the Court of First Instance and five to the Appellate Division. ${ }^{1276}$ Judges are appointed for a five-year term which is renewable once. ${ }^{1277}$ No more than two judges per Member State are allowed to hold a judicial office at any one time. ${ }^{1278}$ The current judges of the CCJ come from 12 of the 19 Member States of COMESA. ${ }^{1279}$

In addition to that, the appointed judges have to be 'persons of impartiality and independence who fulfil the conditions required for the holding of high judicial office in their respective countries of domicile or who are jurists of recognised competence. ${ }^{1280}$

According to Art. 20 of the COMESA Treaty, the judges are nominated by the Council of Ministers, while the COMESA Authority of Heads of States and Governments finally appoint the Judges.

In general, the COMESA Council of Ministers is responsible to 'give directions to all other subordinate organs of the Common Market other than the [CoJ] in exercise of jurisdiction. ${ }^{1281}$ Thus, similar to the other regional and subregional courts, the appointment of the judges is dependent on the Heads of State and Government, which may choose those judges, which may not disagree with their politics.

\section{b) Access to the COMESA Court of Justice}

Similar to most other international courts within the region, the access of the individual is often crucial in achieving an effective protection of human rights. Usually, most international courts, as already can be seen with the other courts discussed in this work, originally were created to only resolve inter-state disputes.

Apart from the respective COMESA Member States and institutions, the CCJ also provides access for private and legal persons within the whole COMESA region to forward a case to the institution. ${ }^{1282}$ Therefore, every natural or legal person has

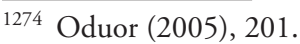

1275 See: Rule 11 of the 2016 Rules of Procedure of the COMESA Court of Justice.

1276 See: Art. 20(1) of the 1994 Treaty Establishing the Common Market of Eastern and Southern Africa.

1277 Viljoen (1999), 206.

1278 See: Art. 20(2) of the 1994 Treaty Establishing the Common Market of Eastern and Southern Africa.

1279 Kayihura (2010), 584.

1280 Ibid.

1281 Gathii (2011), 265.

1282 See: Art. 26 of the 1994 Treaty Establishing the Common Market of Eastern and Southern Africa.
} 
the right to review the 'legality of any act, regulation, directive or decision of the Council or any Member State to the Court.' ${ }^{\prime 283}$ The requirements for access of individuals are similar to those employed by the ECOWAS and the EAC Court. ${ }^{1284}$

In the case of Polytol Paints v. Mauritius, ${ }^{1285}$ the COMESA Court decided not to hear claims from private citizens on matters relating to the non-fulfillment of a Treaty obligation. In its judgment the Court found that it could only hear claims against measures that are unlawful or which constitute a violation of the COMESA Treaty. ${ }^{1286}$ However, in order for any case to be brought before the CCJ, individuals need to normally exhaust all other remedies in the national courts. ${ }^{1287}$ The background to this case was that the Mauritian company Polytol Paints brought a claim against the government of Mauritius for imposing customs duty of 40 percent. At the time of the claim, such customs duty was not consistent with the regulations of the Treaty of COMESA. ${ }^{1288}$ The CCJ found that only a Member State or the Secretary General, rather than private citizens, may have the right and duty to bring a claim against the non-fulfillment of Treaty obligations. ${ }^{1289}$ At the same time, however, the CCJ decided that COMESA residents principally do have the right to claim before the Court, since:

The proper functioning of the Common Market is ...therefore, not only a concern of the Member States but also of the residents. The Treaty is more than an agreement, which merely creates obligations between Member States. It also gives enforceable rights to citizens residing in Member States. ${ }^{1290}$

In its findings, the CCJ referred to Art. 26 of the COMESA Treaty, which provides that:

\footnotetext{
1283 Viljoen (1999), 207.

${ }^{1284}$ Lehmann (2003), 277.

1285 Polytol Paints v. Mauritius, Reference No. 1 of 2012, Judgment of 1 December 2012.

1286 See: W. Mwanza, 'Polytol Pains v Mauritius: Evidence of the existence and direct effect of community law in COMESA?', TRALAC (29 January 2014) available at: https://www.tralac.org/ publications/article/5551-polytol-paints-v-mauritius-evidence-of-the-existence-and-direct-effectof-community-law-in-comesa.html, (last visited: 25 July 2018), 5.

${ }^{1287}$ Lehmann (2003), 278.

1288 Official Website of the COMESA Court of Justice, 'The COMESA Court of Justice rules that Mauritius breached the COMESA rules for the Free Trade Area and orders a refund of customs duties to a small company', (16 October 2015), available at: comesacourt.org/the-comesa-courtof-justice-rules-that-mauritius-breached-the-comesa-rules-for-the-free-trade-area-and-orders-arefund-of-customs-duties-to-aTrade Mark Southern Africa-small-company-2/, (last visited: 12 July 2016).

${ }^{1289}$ Mwanza (2014), 5.

1290 Official Website of the COMESA Court of Justice, 'The COMESA Court of Justice rules that Mauritius breached the COMESA rules for the Free Trade Area and orders a refund of customs duties to a small company', (16 October 2015), available at: comesacourt.org/the-comesa-courtof-justice-rules-that-mauritius-breached-the-comesa-rules-for-the-free-trade-area-and-orders-arefund-of-customs-duties-to-aTrade Mark Southern Africa-small-company-2/, (last visited: 12 July 2016).
} 
[A] ny person who is resident in a Member State may refer for determination by the Court the legality of any act, regulation, directive, or decision of the Council or of a Member State on the grounds that such act, directive, decision or regulation is unlawful or an infringement of the provisions of the Treaty. ${ }^{1291}$

Apart from the claims from individuals or legal persons who are resident in the COMESA, the CCJ may further hear disputes between COMESA and its employees, as well as claims being raised by third parties against COMESA itself or its institutions. ${ }^{1292}$ Art. 27(1) of the Treaty gives the Court jurisdiction 'to hear disputes arising from the application and interpretation of the staff rules and regulations of the Secretariat or the terms and conditions of employment of the employees of the Common Market.'

Furthermore, the Secretary-General is competent to bring cases before the CCJ, but the Council of Ministers first has to decide whether the case should be reported to the CCJ. ${ }^{1293}$ Apart from that, no actions authorized by the COMESA Treaty may be claimed before the CCJ. ${ }^{1294}$

In contrast to the SADC Tribunal, the ECJ and the EACJ, the Treaty Establishing the COMESA Court of Justice demands for the exhaustion of domestic remedies. This regulation aims to find a balance between two interests: first, the involved country may still have the opportunity to find a decision under local remedies before an international remedy is used. Further, the claimant receives the opportunity to make use of an international remedy if there is no availability of adequate or effective national remedies. ${ }^{1295}$

With accordance to the COMESA Treaty, a resident in any of the Member States has the right to file a claim at the CCJ for 'any act, regulation, directive, or decision of the Council or of a Member State on the grounds that [it] is unlawful or an infringement of the provisions of [the] Treaty [...].' ${ }^{1296}$

1291 See: Art. 26(1) of the 1994 Treaty Establishing the Common Market of Eastern and Southern Africa.

${ }^{1292}$ K. K. Mwenda, 'The Common Market for Eastern and Southern Africa (COMESA) and the COMESA Court: Immunity of an international organisation from legal action', 6 Miskolc Journal of International Law (2009), 60, 64.

1293 See: Art. 25 of the 1994 Treaty Establishing the Common Market of Eastern and Southern Africa.

1294 van Weijen (2000), 156.

1295 Gathii (2011), 265.

1296 See: Art. 26 of the 1994 Treaty Establishing the Common Market of Eastern and Southern Africa. 
In general, the decisions issued by the CCJ have precedence over the decisions of domestic courts. ${ }^{1297}$ However, with regard to Art 29(1) of the Treaty establishing the COMESA ' $[\mathrm{e}] \mathrm{xcept}$ where the jurisdiction is conferred in the [CoJ] by or under [the] Treaty, disputes to which the Common Market is a party shall not on ground alone, be excluded from the jurisdiction of national courts.' ${ }^{1298}$

Generally, the CCJ may also be asked to issue an advisory opinion, if no real dispute exists between parties. ${ }^{1299}$ For example, the Council of Ministers may ask the Court to give 'advisory opinions on matters affecting the Council.' 1300

Apart from that, domestic courts of COMESA Member States may request a preliminary ruling from the CCJ where a question is raised before such national court concerning the application or interpretation of the Treaty or the validity of an Action by COMESA. ${ }^{1301}$ Also, where any question is raised in a national court of a Member State and the domestic law of the involved Member State does not provide for an effective judicial remedy for such violation of the COMESA Treaty, the national court shall refer the matter in question to the CCJ, as per Art. 30(2) of the COMESA Treaty.

\section{c) The jurisdiction of the COMESA Court of Justice (CCJ)}

The COMESA Court of Justice, providing access not only to its Member States but also for individuals and NGOs, holds an extensive jurisdiction mandate.

The Court, in general, has to entertain all disputes that are referred to it under the Treaty. ${ }^{1302}$ Apart from an advisory jurisdiction, the Court is mandated to issue enforceable jurisdiction. ${ }^{1303}$ In general, the decisions of the Court are binding, and Member States are obliged to implement the Court's findings without any delay. ${ }^{1304}$

1297 J. T. Gathii, 'Sub-Regional Court or Employment Tribunal? The Legacy and Legitimacy of the COMESA Court of Justice', Loyola University of Chicago School of Law Research Paper (2015), 1, 14.

1298 Ibid.

1299 Oduor (2005), 202.

1300 See: Art. 9(2)(c) of the 1994 Treaty Establishing the Common Market of Eastern and Southern Africa.

1301 Gathii (2015), 7.

1302 See: Art. 23 of the 1994 Treaty Establishing the Common Market of Eastern and Southern Africa; see also: Oduor (2005), 200.

1303 Viljoen (1999), 207.

${ }^{1304}$ Ibid.; see also: Preamble of the 1994 Treaty Establishing the Common Market of Eastern and Southern Africa. 
The question of the protection of human rights through the CCJ is not yet totally clear. At present, it appears that it is not the overriding goal of COMESA. ${ }^{1305}$ Nevertheless, it has to be noted that the Preamble of the COMESA Treaty refers to 'the principles of international law governing relations between sovereign States, and the principles of liberty, fundamental freedoms and the rule of law.' ${ }^{1306}$

The Treaty itself does recognize the protection of human rights as one of the fundamental principles of COMESA. Art. 6(e) 'describes the recognition, promotion and protection of human and peoples' rights in accordance with the provisions of the African Charter on Human and Peoples' Rights. Additionally, the recognition of the principles of rule of law and of a human system is laid down in the Treaty. ${ }^{1307}$ The Treaty also states that trade may have a poor influence on human rights and hence stipulates, that it 'allows States to impose restrictions on trade affecting, inter alia, human, animal or plant health or life, the protection of public morality, or the maintenance of food security in the event of war and famine. ${ }^{1308}$

Furthermore, the Preamble of the Treaty refers to 'the principle of international law governing relations between sovereign States, and the principles of liberty, fundamental freedoms and the rule of law.' Thus, the Treaty makes it clear that the protection of human rights may not be ignored and in some cases may also have a more important standing than trade-related issues. ${ }^{1309}$ In summary, it can be stated that the Court has the potential to hear cases that involve human rights - especially due to the fact that it provides access for individuals. ${ }^{1310}$ However, in contrast to the ECOWAS Court of Justice and the East African Court of Justice, the COMESA Court of Justice does barely entertain cases involving human rights. ${ }^{1311}$

Since the COMESA Court is not supported through NGOs or regional bar associations that normally bring cases before courts, the Court lacks cases being submitted to it. As a consequence, non-governmental organizations did not promote a reform to make the CCJ more attractive for individuals. In this relation, the current location of the Court - Sudan - is not an advantage for the CCJ, since sanctions against the Sudanese government have been imposed and which are thus hampering the fund-raising for the Court. ${ }^{1312}$

1305 O. Ruppel, 'Regional economic communities and human rights in East and Southern Africa', A. Bösl \& J. Diescho (eds), Human Rights in Africa, Legal Perspectives on their Protection and Promotion (2009), 275, 286.

1306 See: Art. 6(g) and (h) respectively of the 1994 Treaty Establishing the Common Market of Eastern and Southern Africa.

1307 Ibid.

1308 See: Art. 50(1)(c) and (f) of the 1994 Treaty Establishing the Common Market of Eastern and Southern Africa.

1309 Ruppel (2009), 286.

1310 Viljoen (1999), 208

1311 Gathii (2011), 267.

1312 Viljoen (2007), 507. 
However, unlike the other subregional courts within the continent, the COMESA Court is competent to have jurisdiction regarding tort claims. ${ }^{1313}$ In addition, the CCJ is eligible to give monetary relief to a party. Only the ECOWAS Court has similar powers regarding the issue of a monetary relief. However, neither the SADC Tribunal nor the East African Court of Justice provides for similar powers. ${ }^{1314}$

Until today, most cases that have been brought forward by individuals only referred to disputes regarding personnel matters within the COMESA institutions. ${ }^{1315}$

In contrast to the other regional courts such as the EACJ, the COMESA Court of Justice did not make use of its 'interpretative authority expansively.' ${ }^{1316}$

Until 2015, the largest number of cases being heard by the CCJ involved employment disputes. Some of the disputes arose due to the relocation of the Bank of the COMESA from Burundi to Kenya. However, the most challenging cases have been the cases being initiated by the former President of the PTA Bank, Martin Ogang, against the PTA Bank. He argued that he has been removed from his position on an irregular basis. The first claim imposed by $M r$. Ogang was followed by at least more other claims. As a consequence, some of the newly inaugurated judges declined to participate in those proceedings. This reaction arose inter alia due to the fact that the President of the Court, as set out in the Rules of the Court, issued several orders to suspend the actions of the Bank, and to make the Bank and its agents to refrain from removing $M r$. Ogang from the office until the case has been heard before the Court. ${ }^{1317}$

During the proceedings, the Bank argued that it is inviolable due to its immunities. In contrast, the Court held that the Bank is not exempt from its jurisdicltion and that the Charter of the Bank is 'subservient to the Treaty which endowed the Court with jurisdiction over all organs and institutions of the Common Market inclusive of their employees'. ${ }^{1318}$ However, Mr. Ogang finally failed to convince the COMESA Court that the appointment of a new President of the PTA Bank had been done in violation of the rules governing the PTA Bank or the COMESA law. ${ }^{1319}$

The CCJ in past was also confronted with questions relating to the exhaustion of remedies - in The Republic of Mauritius v. Polytol Paints and Adhesives Manufactures Co. Ltd. an issue arises with regard to the availability of effective remedies. In the previous case of Republic of Kenya and the Commissioner of Lands v. Coastal Aquaculture, the question arose if local remedies were exhausted by the applicant.

\footnotetext{
1313 This power is given to the COMESA Court by virtue of Art. 40 of the Treaty Establishing the COMESA, which provides that the 'execution of a judgment of the Court which imposes a pecuniary obligation on a person shall be government by the rules of civil procedure in force in the Member State in which execution is to take place.'

1314 Gathii (2015), 6.

1315 Lehmann (2003), 289.

1316 Gathii (2015), 6 et seq.

1317 Ibid.

1318 Lehmann (2003), 288.

1319 Scharfenberg (2014), 290 et seq.
} 
In this case, the applicant sought to stop the Government if Kenya from compulsory acquiring its two pieces of land and thus, jeopardizing the investment of US\$ 24 million. The applicant already prevailed in the High Court and in the Court of Kenya (the highest national court) while arguing that the acquisitions are inconsistent with Kenyan law. ${ }^{1320}$ When the government of Kenya tried to attempt a third compulsory acquirement of the property, the applicant, as consequence, instead of going back to the Kenyan Court, claimed before the COMESA Court due to the 'lack of satisfactory settlement of the matter necessitated the applicant to file the case before the COMESA Court of Justice'. ${ }^{1321}$ The CCJ however held that the applicant did not exhaust the domestic remedies. ${ }^{1322}$ In contrast to other institutions, such as the African Commission on Human and Peoples Right, the Court did not leave any room for exemptions. Even though the wording of the CCJ's Rules of Procedure $^{1323}$ do not allow any exemptions with regard to the exhaustion-rule, the CCJ would have had the opportunity to make use of its so-called inherent power'. Thus, especially in cases where domestic remedies are not effective or even not available such an exemption would have been useful for the applicants, such as the Coastal Aquaculture Ltd. ${ }^{1324}$ When the case was decided (2001), the CCJ was the only working regional court within the continent. Other courts such as the EACJ or the SADC Tribunal only became inaugurated a couple of years later. Thus, the CCJ did not want to risk a backlash against it since the Kenyan government in this period was quite authoritarian. ${ }^{1325}$

The above-mentioned Polytol Paints $v$. Mauritius case is the only purely trade-related case that has been received by the CCJ. The applicant was a Mauritian manufacturer who imported paints from Egypt and other COMESA Member States. Any customs duties between COMESA Member States have been eliminated from 1 November 2011. However, Mauritius re-imposed a customs duty of 40 percent and other charges on specific products which were imported from Egypt, a COMESA Member State, these included paint products of the applicant. ${ }^{1326}$

\footnotetext{
1320 Ibid.

1321 Eastern and Southern African Trade and Development Bank v. Martin Ogang, Reference No. 1B/ 2000, Judgment of 26 April 2002, 8-9.

1322 Gathii (2015), 12.

${ }^{1323}$ H. Onoria, 'Locus standi of individuals and non-state entities before regional economic integration judicial bodies in Africa', 8 African Journal of International and Comparative Law (2010), $143,154$.

1324 Viljoen (2007), 508.

1325 Gathii (2015), 13.

${ }^{1326}$ G. Erasmus, 'The Polythol judgement of the COMESA Court of Justice: Implications for rulesbased integration', TRALAC (1 July 2015), available at: https://www.tralac.org/publications/ article/7604-the-polytol-judgment-of-the-comesa-court-of-justice-implications-for-rules-basedregional-integration.html, (last visited: 13 August 2018).
} 
After the applicant complained about the inconsistency of the duty with the COMESA law, the Supreme Court of Mauritius dismissed the claim. The applicant succeeded with the claim before the COMESA Court and thus, tariffs were set aside. The Court found that COMESA Member States might not introduce any new tariffs on trade goods, unless those are sanctioned by legal instruments. ${ }^{1327}$

In the most recent decision which was issued in April 2017 - Malawi Mobile Limited (MML) v. Malawi - the CCJ stated that it had no jurisdiction to hear it. The Malawi Mobile Limited, which is a private company, was about to establish a mobile phone network in Malawi. After the revocation of the service license of the applicant, the company sued the Malawian government to compensate business losses the company alleged to have occurred. The applicant States that the termination of the contract between both parties would have been unlawful and would violate Art. 6 of the COMESA Treaty.

Before the case was brought to the COMESA Court, the High Court of Malawi awarded the applicant US\$66.9 million due to the unlawful cancellation of thelicense. In its ruling, the Court stated, that it had no jurisdiction in the matter and urged the company to exhaust all local remedies.

The COMESA Court stated that it did not have jurisdiction in the matter since the case only involves Malawian domestic law. Thus, the Court did not have jurisdiction, as it is only competent to exercise jurisdiction in cases involving the violation of the COMESA Treaty. ${ }^{1328}$ Thus, the Court finds that it is not competent to hear any cases that are solely grounded on the violation of domestic law and may not be tasked to control the legality of any domestic act. ${ }^{1329}$ The Court thus clarified the provisions of Art. 26 of the COMESA Treaty, stating:

Any person who is resident in a Member State may refer for determination the legality of any act, regulation, directive, or decision of the Council or of a Member State on the grounds that such act, directive, decision or regulation is unlawful or an infringement of the provisions of this Treaty.

\section{d) The issue of overlapping jurisdiction}

Since most of COMESA's Member States are also members of either the EAC or SADC, the problem of overlapping jurisdictions inter alia occurs, due to the parallel jurisdiction of several subregional courts within the region over international disputes. Until now, the same case has not been brought before two different subre-

1327 Ibid.

1328 Ibid.

${ }^{1329}$ Malawi Mobile Ltd. v. Government of the Republic of Malawi and the Malawi Communications Regulatory, Appeal 1 of 2016, para 47. 
gional courts. ${ }^{1330}$ Thus, any arising trade disputes may eventually fall under the jurisdiction of either the SADC Tribunal or EAC Court and the Court of the Common Market of Eastern and Southern Africa. ${ }^{1331}$

Most of the activities and objectives of the EAC, SADC and COMESA are very similar - which may lead of 'forum shopping' ${ }^{1332}$ Furthermore, consequences of a possible parallel jurisdiction may delay cases and increase costs. ${ }^{1333}$ To resolve this issue, the first challenge of the Court - and also the most important one - is to improve its reputation at subregional and national level and install trust in its sustainability. This challenge can only be overcome with the improvement of its governance structures and the enhancement of its transparency and accountability to the stakeholders. Currently, the Court is confronted with challenges such as a lack of human, material, logistical and financial resources.

Thus far there has not been any overlapping cases, since most regional courts have not been established for a long time and thus, the number of cases brought before regional courts is still rather modest. ${ }^{1334}$ One reason for this fact may be the large distances within the Common Market. However, the case Intesolmac (Uganda) Limited v. Rwanda Civil Aviation Authority ${ }^{1335}$ shows that the upcoming costs are not the only reason influencing such decision. Another reason is the enforceability of the judgments. In the above-mentioned case the parties lived much closer to the East African Court Registry situated in Tanzania. However, the parties decided to institute the claim before the COMESA Court in Lusaka, Zambia. ${ }^{1336}$ Such rules in general are only available to domestic courts.

However, a case that has been decided before the SADC Tribunal may also be brought before WTO, COMESA, EAC and SACU judicial institutions. ${ }^{1337}$

In order to deal with the problem of forum shopping, the Court decided that it might also consult rules such as estoppels, res judicata as well as lis pendens which are usually not found in international, but domestic law. In the case of PTA Bank v. Yvonne Nyagamukenga, ${ }^{1338}$ the Court stated concerning res judicata that: ' $[\mathrm{T}]$ the successful prosecution of such defense, would bar the Court from adjudicating the substantive grievances for which the Court's door was opened to the aggrieved

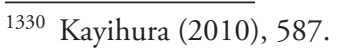

1331 See: Art. 30(1) of the 1994 Treaty Establishing the Common Market of Eastern and Southern Africa.

1332 Kayihura (2010), 585.

1333 Ibid., 592.

1334 Ibid., 585.

1335 Intesolmac (Uganda) Limited v. Rwanda Civil Aviation Authority, Ref. No 1 of 2009.

1336 Ibid.

1337 Dirar (2010), 222.

1338 PTA Bank v. Yvonne Nyagamukenga, Reference No: 03/2006, Judgment of 18 September 2009.
} 
party. ${ }^{1339}$ In effect, the Court would have jurisdiction to entertain the matter but would decline to exercise that jurisdiction on account of the successful defense against applicant's claim. ${ }^{1340}$

\subsection{Conclusion on the Court of the Common Market of Eastern and Southern Africa}

COMESA provides a 'dynamic legalism' whereas the COMESA Court of Justice gives substantial and procedural rights to private persons and companies. ${ }^{1341}$

COMESA is - in the long term - confronted with the problem of overlapping membership, the phenomenon of forum shopping arises between especially with the East African Court, because of the fact that most subregional courts have similar activities and proceedings.

Most recently the COMESA Secretary pointed out that the Court of Justice has been under-utilized since its inception and thus it appears unlikely that the issue of forum shopping will come up in close future. ${ }^{1342}$ Former Judge President Senior Nzamba Kitonga maintained that, besides the very long distances to the Court, the requirement that the claimants first have to complete the domestic appeal stages might be the reason for this underutilization. He further stated that there were several plans under way that would allow the litigants to use the Court directly, instead of applying through the regional courts. ${ }^{1343}$ Kitonga argued that it is an ad hoc court, it does not sit full time; it is however contemplated to make it a full time court if there is enough workload. ${ }^{1344}$ Since the inauguration of the Court in 2005, it decided 49 cases. ${ }^{1345}$ In order to solve the problem of long distances, the Court now tries to make use of videoconferences and moreover wants to make sure that litigants are able to apply to the Court online. ${ }^{1346}$

\footnotetext{
1339 Kayihura (2010), 591.

1340 Ibid.

1341 Oduor (2005), 202.

1342 G. Thipa, 'Comesa Court under-utilised', The Times (21 June 2016), available at: http://www. times.mw/comesa-court-under-utilised/, (last visited: 6 July 2016).

1343 P. Muyanga, 'Comesa Court underutilised, Senior Counsel Nzamba Kitonga says', Daily Nation (August 2015), available at: http://www.nation.co.ke/news/Comesa-court-underutilisedNzamba-Kiton ga-/-/1056/2816492/-/xo384z/-/index.html, (last visited: 6 July 2016).

1344 Thipa (2016).

1345 Muyanga (2015).

1346 Comesa court underutilised, by regional lawyers in practice, The Citizen (2 August 2015) available at: http://www.thecitizen.co.tz/News/Comesa-court-underutilised--by-regional-lawyers-inpractice/-/1840340/2817352/-/qugyk9z/-/index.html, (last visited: 6 July 2016).
} 
At present and as mentioned above most of the decisions by the Court touch upon issues of employment. The Court has not yet received a single case involving issues of human rights. Thus, it appears that environmental or human rights groups are not yet motivated to bring cases involving matters of human rights to the Court. ${ }^{1347}$

Between the EAC Court and the SADC Tribunal, new regional bar associations were established to forward cases. Presently no regional bar association exists that bring cases before the COMESA Court. One reason for that might be that distances are just too long and the law systems too different. It may also be that the level of democratization within the particular COMESA Member States is very different. ${ }^{1348}$

The current location of the Court in the Sudan may, as discussed, pose another problem. The President of the Republic of Sudan, al-Bashir was indicted before the International Criminal Court for war crimes and the violation of human rights. It seems paradoxical that the Court is currently located in a country that does not heed decisions of international courts. ${ }^{1349}$

Although the Court may - through the reference in the Treaty to the African Charter - be mandated to hear human rights cases, it has never been used with that intent. Furthermore, regarding the composition of the Court, the Heads of States and Governments have a big influence on the independence of the judges.

Finally, the COMESA Court receives legitimacy among employers since it had already received some claims involving employees of COMESA institutions.

Besides that, the COMESA Court started its work when most governments were averse to any sort of judicial oversights. Hence, the judges of other regional courts started their work in a period of greater openness within Africa.

However, there may be a sign pointing towards an upcoming importance of the CCJ. Until 2015, the Court has been the only regional court within the African continent which received a case involving two African Member States - namely Eritrea and Ethiopia. Even though the case has been effectively withdrawn from the CCJ, it may be an indicator that the 'diverse and heterogeneous nature' of the COMESA facilitates the prospective submission of cases involving two African governments. ${ }^{1350}$

During a workshop in February 2017, where all judges of the CCJ participated, the judges decided to review the Court's arbitration rules. During the workshop, the judges were about to explore the potential role of the Court in order to boost access to justice through arbitration. ${ }^{1351}$

\footnotetext{
1347 Gathii (2015), 19.

1348 Ibid., 19 et seq.

1349 Ibid., 21.

1350 Gathii (2015), 2.

1351 Scharfenberg (2014), 347.
} 


\subsection{Committees of the Common Market of Eastern and Southern Africa (COMESA)}

COMESA provides for several Committees, such as the Technical Committees, the Consultative Committee and the Inter-governmental Committee, which are competent to give advice on several topics but do not - at this stage, have a parliamentary function.

\subsubsection{Technical Committees of the Common Market of Eastern and Southern Africa (COMESA)}

Technical Committees may aim to constitute a legislative institution in order to promote the protection of the rule of law within COMESA.

According to the wording of Art. 7(1)(b) of the COMESA Treaty, the Technical Committees serve as an organ of COMESA. ${ }^{1352}$ Currently, twelve different Technical Committees are in existence. Art. 15(1) of the COMESA Treaty stipulates the establishment of the following Technical Committees: Administrative and Budgetary Matters; Agriculture; Comprehensive Information Systems; Energy; Finance and Monetary Affairs; Industry; Labor, Human Resources and Social Cultural Affairs; Legal Affairs; Natural Resources and Environment; Tourism and Wildlife, Trade and Customs and Transport and Communications. The Council of Ministers has the authority to, if deems necessary, institute further Committees. ${ }^{1353}$

Technical Committees should be composed of 'representatives of each of the Member States designated for that purpose. ${ }^{1354}$ The Committees are equipped with several competences; hence they are responsible for preparing comprehensive implementation programs providing timetables for implementation. ${ }^{1355}$ They should also review the implementation of various programs. ${ }^{1356}$ Furthermore, the Committees may ask the Secretary-General to undertake specific investigations in order to ensure effective implementation of the programs, Art. 16(a) of the COMESA Treaty.

The implementation proposals of the Technical Committees are recommendations that are forwarded to the Council of Ministers, Art. 16(d). However, the Council of Ministers is not obliged to implement any of the recommendations made by the Committees. The different Technical Committees, at first glance, do not include topics on human rights. Some programs or recommendation may how-

1352 See: Art. 7(1)(b) of the 1994 Treaty Establishing the Common Market of Eastern and Southern Africa.

1353 See: Art. 15(3) of the 1994 Treaty Establishing the Common Market of Eastern and Southern Africa.

1354 See: Art. 15(2) of the 1994 Treaty Establishing the Common Market of Eastern and Southern Africa.

1355 See: Art. 16(a) of the 1994 Treaty Establishing the Common Market of Eastern and Southern Africa.

1356 See: Art. 16(b) of the 1994 Treaty Establishing the Common Market of Eastern and Southern Africa. 
ever touch issues involving human rights. Furthermore, the Committees do not have any binding influence on the decision-banking body. The Treaty of COMESA even does not name the Committee to be a legislative institution within the institutional structure.

All in all, the Technical Committees do not constitute a parliamentary forum governing the rule of law and it appears that the goal of the Technical Committee is not the protection of human rights.

\subsubsection{Consultative Committee of the Common Market of Eastern and Southern Africa (COMESA)}

Apart from the Technical Committees, Art. 7(1)(h) of the COMESA Treaty provides for a Consultative Committee, composed of members of the business community and other interest groups and acting as one of the organs of COMESA. ${ }^{1357}$

The Treaty points out four major functions of the Consultative Committee: first, it is responsible for ensuring that the interests of the business community and other interest groups are taken into consideration satisfactorily by the various organs of COMESA. ${ }^{1358}$ Second, the Committee has the responsibility for ensuring the satisfactory implementation of the various provisions set out in Chapters 23 and 24 of the Treaty. ${ }^{1359}$ Third, the Committee receives reports from other interest groups and fourth is authorized to participate in meetings of the Technical Committees. ${ }^{1360}$

\subsubsection{Intergovernmental Committee of the Common Market of Eastern and Southern Africa}

Besides the establishment of the Technical Committees and of the Consultative Committee, which are eligible to issue several recommendations, the COMESA Treaty pretends the establishment of an Intergovernmental Committee.

The Intergovernmental Committee is composed of permanent secretaries, seconded by COMESA Member States, who have to deal with matters over a wide spectrum of disciplines. ${ }^{1361}$ Representatives from Member States should come from

1357 See: Art. 7(1)(h) of the 1994 Treaty Establishing the Common Market of Eastern and Southern Africa.

1358 See: Art. 18(3)(a) of the 1994 Treaty Establishing the Common Market of Eastern and Southern Africa.

1359 See: Art. 18(3)(b) of the 1994 Treaty Establishing the Common Market of Eastern and Southern Africa.

1360 See: Art. 18(3)(c), (d) of the 1994 Treaty Establishing the Common Market of Eastern and Southern Africa.

1361 A. Okot, A history of Africa (1998), 344. 
the business community and from other interest groups. ${ }^{1362}$ Generally, they come from the fields of agriculture, legal affairs, trade and customs, industry, and administrative and budgetary matters.

A simple majority is usually adequate for the decisions of the Committee. ${ }^{1363}$

The focus of the Intergovernmental Committee is to develop programs and action plans of every sector, except the finance and monetary sector. ${ }^{1364}$ Further to that, it is responsible for ensuring the functioning and development of the Common Market and the implementation of the provisions of the Treaty. ${ }^{1365}$ In order to fulfill its responsibilities, the Committee is entitled to forward requests to the Technical Committees for further investigation. ${ }^{1366}$ Unless the Council indicates otherwise, the Intergovernmental Committee has to meet at least once a year. ${ }^{1367}$ The Committee may make recommendations to the Council that may be forwarded to the Authority. ${ }^{1368}$

\subsection{Conclusion on the Committees of the Common Market of Eastern and Southern Africa}

The several Committees do provide for several advisory structures within COMESA. None of the recommendations of the Committees are however of binding character and thus do not effectively influence the Heads of State and Government - being the decision-making body with regard to COMESA law. The COMESA Treaty does not refer to the establishment of legislative institutions within COMESA. It appears unlikely that there exists a genuine call towards the establishment of a fully-fledged parliament on the level of COMESA. One reason for this might be the fact that Member States of both the SADC and the EAC are hesitant with regard to the transmission of powers to the parliamentary institutions on such levels. Furthermore, the size of the COMESA area - and the thereby related differences between cultures and legal system might discourage the establishment of such institution in near future. Furthermore, the need for more financial resources resulting from the establishment

1362 See: Art. 18(1) of the 1994 Treaty Establishing the Common Market of Eastern and Southern Africa.

1363 Okot (1998), 344.

1364 See: Art. 14(2)(a) of the 1994 Treaty Establishing the Common Market of Eastern and Southern Africa.

1365 See: Art. 14(2)(b) and (c) of the 1994 Treaty Establishing the Common Market of Eastern and Southern Africa.

1366 See: Art. 14(2)(c) of the 1994 Treaty Establishing the Common Market of Eastern and Southern Africa.

1367 See: Art. 14(3) of the 1994 Treaty Establishing the Common Market of Eastern and Southern Africa.

1368 A. Marawa, 'The COMESA Air Transport Liberalization Experience', ICAO (March 2003), available at: http://www.icao.int/Meetings/ATConf5/Documents/Marawa.pdf, (last visited: 28 June 2016). 
of such institution does bring forward an argument opposing the establishment of a parliament, since the financial resources of the Member States - often due to the overlapping memberships - are limited.

\subsection{Final Conclusion on the Common Market of Eastern and Southern Africa}

COMESA was the largest subregional bloc in Africa prior to the above-mentioned establishment of the Tripartite-Free-Trade Area (TFTA). However, until today irrespective of the formation of the Customs Union intra-regional trade is very low. One reason for that is that not all Member States recognize COMESA as their main regional trading block due to their membership in smaller subregional blocs. Besides that, the Common Market is still faced with essential problems such as different political obstacles to integration, for example Member States such as the Democratic Republic of Congo and Somalia are also still embroiled in civil wars. ${ }^{1369}$

However, in general, COMESA is one of the successful subregional cooperation and integration organizations on the African continent. With the support of its institutions, being specialized in financial matters, COMESA was able to implement a significant number of programs such as activities improving the infrastructure, industry and agriculture as well as climate change. ${ }^{1370}$ However, due to the different judicial systems, such as anglo-dutch civil law, islamic law as well as the different languages, the harmonization process is very difficult.

However, in comparison to the AU and the other subregional agreements in sub-Saharan Africa which have been analyzed in this paper, the COMESA is the only REC which neither provides for any active human rights protection mechanism nor any institution which comes close to a parliamentary institution.

The main objectives of the COMESA - thus far - seem to be more related to economic integration than to effective promotion of the rule of law. Certainly, the protection of human rights is considered in Art. 6 of the Treaty, however, the main objectives of the COMESA refer to a greater economic development within the area of Eastern and Southern Africa. However, with regard to human rights protection, Art. 6(e) of the Treaty but also Chapter six of the Treaty, dealing with the cooperation of trade underline the importance of the rule of law within COMESA. Art. 50(c) of the Treaty allows the imposition of restrictions on trade which inter alia affects human, animal or plants health and life. Thus, COMESA Treaty recognizes the connection between economic development and human rights protection. Furthermore, Chapter 24 of the COMESA Treaty deals with women in development and business.

$\overline{1369}$ Saurombe (2011), 401.

1370 D. Luke \& Z. Mabuza, 'The Tripartite Free Trade Area Agreement: A milestone for Africa’s regional integration process', ICTS (23 June 2015), available at: https://www.tralac.org/resources/by-region/ comesa.html, (last visited: 02 October 2020). 
The COMESA Court however, still being an ad hoc institution, has not yet issued a decision involving human rights. Due to the very different legal systems within COMESA - the establishment of supporting regional bar institutions, which actively push towards an effective human rights protection remains difficult. However, the institution provides access for individuals - in case of the complete exhaustion of domestic remedies of the respective Member State. Since Art. 6 of the COMESA Treaty provides for the principle of human rights protection, a link is provided for the Court to extend its jurisdiction on human rights matters. The Court, especially taking into consideration the dissolution and the therewith related termination of access of individuals to the SADC Tribunal may lead to a more frequent use of the Court of individuals by SADC citizens.

Furthermore, the COMESA does not provide for any effective parliamentary structure. The mandates of the Committees are very limited. They may initiate programs, but no higher institution within COMESA is bound by any of the decisions. Furthermore, the programs of the Committees do not directly refer to the protection of human rights.

The COMESA region includes parts of three subregions - the EAC, SADC and the Intergovernmental Authority on Development (IGAD). ${ }^{1371}$ This renders it very difficult for COMESA to gain acceptance as a kind of regional superstructure. Because of issues arising from overlapping membership, some countries - Angola in 1996, Mozambique and Lesotho in 1997, Tanzania in 2000, and Namibia in 2004 - had left COMESA. South Africa also never intended to join COMESA and for that reason, SADC gained in strength. ${ }^{1372}$

1371 The Intergovernmental Authority on Development was created in 1996 in Addis Ababa, and the current member countries are Djibouti, Eritrea, Ethiopia, Kenya, Somalia, Sudan, Uganda. see: Official Website of the Intergovernmental Authority on Development, available at: https://igad. int/, (last visited: 6 September 2018).

1372 Comesa court underutilised, by regional lawyers in practice, The Citizen (2 August 2015) available at: http://www.thecitizen.co.tz/News/Comesa-court-underutilised--by-regional-lawyersin-practice/-/1840340/2817352/-/qugyk9z/-/index.html, (last visited: 17 June 2016). 


\section{Chapter 8: Conclusion}

Overall, on all three levels, namely the level of the UN, the African Union and subregional levels, international organizations aim to protect human rights.

At present in the Western World the impression may still exist that in Africa, economic interaction as well as the protection of human rights is not taking place. This view ignores the fact that the continent in general offers high potential in intraregional trade and economic action, which has the potential to eventually boost every domestic economy. ${ }^{1373}$ According to Viljoen, 'regional economic integration is not a goal in itself, but a means to an end - the eradication of poverty.' 1374

Next to the increase of economic integration, the development of international human rights at regional but also subregional level throughout the African continent continued to advance during the last decades.

Especially, the end of the Cold War had a strong impact on the African continent and its adherence to human rights. Particularly States with socialist orientation were drawn towards the protection of human rights. One reason for this is that Western States attach conditions to the allocation of loans and investments. Thus,

1373 Kleis (2016), 367.

1374 Viljoen (2007), 496. 
African States have to comply with some conditions of the Western States, in order to receive the loans, which in the last decades lead to a greater activism especially with regard to human rights protection among African countries.

In the opinion of Frans Viljoen however, one needs to distinguish between the duty to 'promote, respect, protect and fulfill rights. ${ }^{1375}$ Thus, most African countries and therewith related regional and subregional level governments generally comply with the obligation to promote human rights through statements and several campaigns as well as the signing of international treaties. Such treaties however, are rarely implemented effectively. However, many treaties aiming to establish an international institution on subregional and regional level within Africa (such as the Protocol on the African Court on Justice and Human and Peoples' Rights and the SADC Tribunal) are not yet in force due to the lack of sufficient ratifications. Gathii maintains that the African regional trade agreements represent a 'flexible legal regime', characterized by: 'lack of enforcement, variable geometry, a wide array of objectives, discrete projects and equitable distribution of gains. ${ }^{1376}$ However, the so-called flexibility has the objective to maintain members' sovereignty and to launch many different integration schemes without having any intention of enforcing them. ${ }^{1377}$

One reason for the establishment of human rights related institutions on region$\mathrm{al}$ and subregional level is the fact that the human rights level on national basis is very low within many African States. Thus, the question may come up, if regional courts constitute an alternative to national courts. Nwauche aptly comments on the issue: 'Regional human rights protection is often a reaction against the failing of nation States operating on the assumption that the pooled resources of a regional understanding will overcome the weakness of national human rights systems. ${ }^{1378}$ Taking into consideration the achievements of the European Union, most nations around the continent are willing to imitate the EU, since it has achieved some kind of 'superpower status'. At the same time, the EU projects itself to be a very successful regional trade agreement, whom external States wish to join. As such, the EU has a very high influence worldwide regarding the set-up of regional trade agreements in general, but also the protection of human rights and the rule of law on regional level. ${ }^{1379}$

The jurisdictional arm of the African Union currently provides for two working institutions which are still quite weak in their functioning. For instance, the African Commission is quite active nowadays but is on delay with many communications

\footnotetext{
1375 Ibid., 605.

1376 Gathii (2015), 2.

1377 Dirar (2010), 219.

1378 E.S. Nwauche, 'Regional economic communities and human rights in West Africa and the African Arab countries', Konrad Adenauer Stiftung, available at: https://www.kas.de/c/ document_library/get_file?uuid=15d35401-4cdd-a11e-9c1e-f1035afeafa3\&groupId=252038, (last visited: 24 September 2019), 1.

1379 Viljoen (2007), 414 et seq.
} 
due to the fact that it the Commissioners are only working on part-time basis and thus only meet twice a year. However, the communications show an increasing development and thus the Commission most lately envisaged the respondent to pay the plaintiff a fixed amount of money. However, its communications are not of binding character and thus, it is still quite problematic to enforce the decisions of the Commission.

Moreover, the African Court on Human and Peoples' Rights - in contrast to the African Court of Justice - was established successfully. The African Court of Human Rights however, as of yet, has not been very active, as it has not received many claims. One reason may be the fact that the individuals only have a very restricted access to the Court. In recent years, the Court however filed a number of landmark decisions giving reason for hope on a functioning human rights court on regional level. Thus, as already described above - it is upon the Commission to forward claims to the Court. Since the Commission is quite overworked, it is doubtful that it would be a reliable partner for individuals to have access to the Court - however, at least the Commission forwarded one decision to the Court which had been decided on successfully by the Court.

Furthermore, the plans to merge both, the African Court of Justice and the African Court on Human and Peoples' Rights and to establish Criminal Chamber within the merged Court may have negative impacts on the human rights protection on the level of the African Union. One reason is the limitation of judges who have jurisdiction on human rights and another reason will be the huge financial impact arising from the jurisdiction on international crimes.

Another concern is the fact that African Heads of State and Government decided to ensure immunity of serving Heads of State and Government as well as ex-State officials.

Thus, in recent years, many developments towards the effective protection of the rule of law took place, however still with many limitations with regard to their effectiveness.

Besides the African Union, many RECs have been set up, initially without the feature of human rights protection. Only with the beginning of the new millennium, the objectives of all RECs in the sub-Saharan region changed from being solely focused on security, peace and economic goals towards greater attention to the protection of the rule of law. A strong push towards better recognition of the principles of democracy and human rights took place at the beginning of 1990 s due to the end of colonialism. ${ }^{1380}$

Comparing all RECs that have been analyzed above - thus SADC, EAC, ECOWAS and COMESA, it is apparent that they provide a different level of economic integration as well as a different level of promotion and protection of human rights and popular participation.

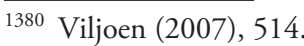


The East African Community (EAC) is by far the most developed REC regarding the implementation of integration goals. A similar result comes out concerning the protection of human rights and the rule of law. In particular, EAC provides for a Parliament that is able to adopt bills in some human rights-related areas that are fully-binding. Thus the level of participation of the peoples in the East African Community is relatively high compared to other economic communities. A similar development may be perceived regarding the Economic Community of West African States (ECOWAS): The Heads of State and Government enhanced the powers of parliament little by little. However, both sub regional parliaments are still far from being called a fully-fledged parliament - the reason is the missing universal suffrage and the missing competences. In contrast to that, the legislative arm of SADC and COMESA remain quite undeveloped. The SADC Parliamentary Forum does not constitute an official organ of SADC and the Parliamentary Forum may adopt no binding bills. COMESA, in this regard remains the most undeveloped REC with regard to the establishment of a subregional parliament, since it only provides for several Committees that are eligible to inter alia develop programs, which are not of binding character.

As already pointed out above, all subregional institutions provide for a court, primarily established in order to solve trade-related claims. Most of the courts - with exception to the COMESA Court of Justice - have recently become more involved in human rights-related claims. ${ }^{1381}$

With regard to the courts of justice, the economic communities provide for a similar structure: the courts of justice were meant to be used for trade related cases. In addition, the structure of the courts including the procedure of selection of the respective judges is similar. However, the jurisdiction of the subregional courts differs since the ECOWAS Court is officially competent to hear human rights related cases. Other subregional courts are not - by the respective treaties - competent, to hear such cases. Thus, the Court of the EAC and the SADC Tribunal declared themselves to be competent to hear such cases. The COMESA Court was not yet confronted with cases that refer to the violation of human rights and thus there was no need for the extension of its jurisdiction.

In general, all subregional courts need to meet at least three requirements in order to constitute an effective human rights institution. First of all, access of individuals to the respective court needs to be guaranteed. This is the most crucial requirement for a court to be considered as human rights court. The ECOWAS and the EAC Court of Justice, next to the Court of Justice of COMESA being still very inactive - are the Courts, which are officially competent to receive claims by individuals. Besides that, the SADC Tribunal - before it became dissolved - was capable to receive claims by individuals. The new Protocol to the SADC Tribunal only allows claims submitted by Member States. The African Court of Human and Peoples' Rights, coming back to regional level - only accepts claims by individuals if

1381 Scharfenberg (2014), 299. 
the respective AU State signed a declaration allowing such submission to the Court. The Commission is allowed to forward communications to the African Court on Human and Peoples' Rights, but this possibility still does not guarantee access for individuals, since the submission depends on the decision and the will of the commissioners of the African Commission.

Secondly, the judicial institutions have to be in function. All of the judicial institutions with exception of the SADC Tribunal are currently in function. It remains to be seen when the new Protocol on the SADC Tribunal will be adopted by sufficient SADC Member States, in order to become functional. All other above analyzed subregional courts are fully functional. The ECOWAS Court even survived a backlash initiated by The Gambia.

Lastly, the respective legal framework has to provide for a normative basis to issue claims on human rights. It appears problematic that none of the RECs until today provide for own human rights standards or instruments. Thus, global human rights standards, developed by the UN and the African Charter on Human and Peoples' Rights are used as legal instruments on subregional level. Besides that no one of the UN human rights documents is yet accepted by all African States which may become an issue with regard to the enforcement of the judgments of the subregional courts. ${ }^{1382}$

However, and especially, due to the planned merger of the RECs with the AU and the AEC, it appears reasonable to use the African Charter on Human and Peoples' Rights as a common human rights standard. Subregional instruments, such as the SADC Charter on Fundamental Social Rights may then in relation to the African Charter provide for some additional human rights protection on subregional level. The development of subregional human rights Charters would undermine the move towards unity within the African continent. The use of the African Charter as a common standard follows closely to the developments within the European Union. ${ }^{1383}$ The subregional courts mostly were confronted with cases involving the violation of first-generation human rights that are protected through the African Charter. However, the ECOWAS Court also aimed to protect third-generation human rights through its judgment. The case SERAP Environment $v$. Republic of Nigeria - as mentioned above in chapter 4.5.3 - refers to the damage of the environment in the Niger Delta. Besides that, the ECOWAS Court - referring to the case SERAP Scholar v. Republic of Nigeria - recognized that the right to education (Art. 17 of the African Charter) forms a justiciable right. The Court further found, that the right to education - constituting a second-generation human right - to be justiciable within the Republic of Nigeria.

\footnotetext{
1382 Viljoen (2007), 500.

1383 Ibid, for more details see: G. Amato, E. Milanesi, G. Pasquino, L. Reichlin (eds), The history of the European Union: constructing utopia (2019).
} 
With regard to subregional courts, it is conspicuous that most of them are not mandated through a protocol or treaty to hear human rights related cases. The ECOWAS Court of Justice is the only subregional court, which in official manner through a Protocol, received the competence to have jurisdiction on human rights related claims. All other Courts gave themselves the competence to hear human rights claims. In case of SADC Tribunal, the government of Zimbabwe did not agree with the self-empowerment of the Tribunal and thus campaigned for the dissolution of the Tribunal. Besides of the EAC and ECOWAS Court of Justice, the COMESA Court of Justice did not yet have the jurisdiction to decide on human rights related matters. Especially with regard to the limitations of competences and jurisdiction of the SADC Tribunal, its activism and role in future may become more and more important.

Thus, as the example of the SADC Tribunal shows, the further existence and powers of subregional courts is still dependent of the will of the Heads of State and Government. Taking into consideration the failed backlash of the ECOWAS Court, the support of NGOs is a key factor with regard to the interference of Heads of State and Government since they may repel any attempts of the Heads of State and Government limiting the competences of the respective courts.

Finally, the question of the relationship between the several subregional courts and the courts on the African Union level calls for a discussion. The idea may come up to use the African Court as an appellate division for subregional courts decisions. This discussion, however, is only on theoretical basis since no such move has been made until today.

An issue with regard to the transfer of a case being decided by a subregional court to the African Court is that the decisions of international courts - thus also of subregional basis - are generally binding and final which could violate the Treaty of the respective REC. Additionally, there is no existing legal basis, which allows the reference of decisions of a subregional court to the African Court of Human and Peoples' Rights.

The transfer of a case to the African Court of Human and Peoples' Rights that is already decided by a subregional institution would also lead to the violation of the principle of double jeopardy. The human rights principle, which is recognized in common law jurisdictions means that one shall not be prosecuted twice for the same crime. Art. 56(7) of the African Charter in this regard state that any matters - also intra state matters - shall not be reviewed for a second time. Thus, the review of settled cases by the African Commission or the African Court of Human and Peoples' Rights could lead to a violation of Art. 56(7) of the Charter. In Bakweri Land Claims Committee v. Cameroon, a case was brought before the institution, which had already been settled by the UN Sub-Commission on Promotion and Protection of Human Rights. The case involved the sale of land which was owned by Bakweri which is an indigenous community within Cameroon. In this case the Commission held that 'the principle behind the requirement under this provision 
of the African Charter is to desist from faulting Member States twice for the same alleged violations of human rights This is called the ne bis in idem rule (also known as the principle or prohibition of double jeopardy, deriving from criminal law) and ensures that, in this context, no State may be sued or condemned for the same alleged violation of human rights.' 1384

Additionally, the principle of double jeopardy comes close to the principle of res judicata. The African Commission defines the res judicata principle as the 'principle that a final judgment of a competent court/tribunal is conclusive upon the parties in any subsequent litigation involving the same cause of action.' Thus, both the African Commission as well as the African Court of Human and Peoples' Rights should not admit cases that have been decided by sub regional courts. ${ }^{1385}$ In order for a case to become bared by the res judicata principle, the case needs to pass the so-called 'triple-identity' test which is, for instance also used by the Court of the East African Community, being developed under the provisions of the Civil Procedure Acts of Kenya, Tanzania and Uganda. Thus, the Court recognizes three situations where the res judicata principle applies: 'One, the matter must be directly and substantially in issue in the suits. Two, parties must be the same parties under whom any of them claim litigating under the same title. Lastly, the matter was finally decided in the previous suit.' 1386 'The Commission used this test when deciding on the Bakweri Land Claims Committee v. Cameroon case and stated that the case would be inadmissible due to the res judicata principle. ${ }^{1387}$ Thus, the impression arises that the African Commission and also the African Court of Human and Peoples' Rights might be using the test in case of the submission of human rights related cases that have already been decided by a subregional court. Since most subregional courts are only active on human rights related matters for quite a short time, it might be possible that sooner or later a case that has been judged on subregional level might be submitted to the African Commission or the African Court of Human and Peoples' Rights.

However, most African governments are hesitant to give up some areas of national sovereignty in favor of regional and subregional integration. Nevertheless, in order to reach more success in regional integration, this step is inevitable and essential. ${ }^{1388}$ With regard to the development of the human rights of subregional courts, challenges such as the restricted access to the African Court on Human and Peoples' Rights and lead to an increase of dissatisfaction. Thus, above all NGOs tried to hold responsible national governments before subregional courts. ${ }^{1389}$ As

\footnotetext{
1384 See: Bakweri land Claims Committee v. Cameroon, AHRLR 43 (ACHPR 2004), Communication of: 4 December 2004, para 52.

1385 Ali (2012), 264 et seq.

1386 See Katabazi and 21 Others v. Secretary General of the East African Community and another, Ref. No 1 of 2007, para 31.

1387 Bakweri land Claims Committee v. Cameroon, AHRLR 43 (ACHPR 2004), para 53.

1388 Peter-Berries (2010), 148.

1389 S. T. Ebobrah, 'Human rights developments in African sub-regional economic communities during 2011', 12 Afr Hum Rts LJ (2012), 224.
} 
consequence, it is no more disputable, that human rights can be protected before subregional judicial institutions. ${ }^{1390}$ Thus, during the last years, the number of human rights related claims before subregional courts increased significantly. However, the more visible activity regarding the consideration of human rights remain within the judicial sector of the subregional communities. ${ }^{1391}$ Within the last years, most of the judicial institutions of the RECs are more and more focused to engage with matters concerning possible violations of human rights. The most prominent reason for this phenomenon is the weakness of the African Commission of Human and Peoples' Rights as well as the prolonged process of the set-up of the African Court on Human and Peoples' Rights. Furthermore, many African States do not accept the jurisdiction of the African Court. ${ }^{1392}$

However, in order to achieve the full protection of the rule of law on regional level in Africa, the development of a fully-fledged legislative institution in each regional and subregional trade agreement is very meaningful in order to push towards successful regional integration. The legislative mandate gives legitimation to all activities linked to regional integration. ${ }^{1393}$ The fact that the African regional agreements might only be temporary until they unfold in the AEC, does not justify their loss of legal credit. ${ }^{1394}$

The recent establishment of the Tripartite Free Trade Area (TFTA) combining COMESA, SADC and EAC, does not improve the future human rights protection within those areas, but rather means a step towards the establishment of an African Economic Community. However, the situation may also become important for the COMESA Court, since most SADC Member States are also parties to COMESA.

The effective human rights protection of the TFTA will depend inter alia on the effective implementation of legal instruments whilst limiting the Member States' protection of their sovereignty. ${ }^{1395}$

Taking into consideration the merger of SADC, COMESA and EAC into the Tripartite Free Trade Area, one may ask about the future of the subregional courts. Art. 30 of the TFTA Agreement provides for the creation of a dispute settlement body with powers to establish panels and an Appellate Body. It further ensures the implementation of the rulings done by the panels. The recent Dispute Settlement comes close to the WTO Dispute Settlement Understanding and will decide on trade-related cases but not on cases on human rights or other disputes that arise

\footnotetext{
1390 S. T. Ebobrah, 'Human rights developments in African sub-regional economic communities during 2012', 2 Afr Hum Rts LJ (2013), 178 et seq.

1391 S. T. Ebobrah, 'Human rights developments in African sub-regional economic communities during 2011', 12 Afr Hum Rts LJ (2012), 224.

1392 Viljoen (2007), 487.

1393 Musavengana (2011), 32.

${ }^{1394}$ Kleis (2016), 370.

1395 G. Erasmus, 'Legal and institutional aspects of the Tripartite Free Trade Area: the need for effective implementation', in Hartzenberg et al (eds), The Tripartite Free Trade Area - towards a new African integration paradigm? (2012), 34.
} 
from a community treaty. Such questions should be left to a central and independent judicial organ, which - however - still needs to become established. ${ }^{1396}$ Thus developments in this regard are still quite unforeseeable as well as the activity of the court itself. Additionally, the TFTA Agreement determines the creation of several Committees to ensure the implementation of the TFTA. ${ }^{1397}$ At the same time - similar to the Common Market- the TFTA Agreement does not provide for an institution that embodies a fully operating parliament.

It is to be concluded, that African cultures and societies and constitutions do have been recognizing human rights and the protection thereof since a couple of decades. But nonetheless the meaning of those rights that constitute a base for a functioning political culture still has to become explored by the African societies. ${ }^{1398}$ To this day, Africa is the continent with the worst human rights records in the world. ${ }^{1399}$

The research shows, that the potential of human rights and therefore the effective promotion of the rule of law only have been realized to a very small extent. Treaties, that are signed but not yet ratified need to become enforced. Since such matters depend on the willingness of politicians it is unlikely to happen in near future. Furthermore, institutions that are already established and fully functioning need to ensure their full acceptance from involved countries. Besides that, financial issues need to be eliminated to ensure the full unfolding of institutions among the continent.

It is to be hoped that further education and trainings in rule of law topics among the continent will sooner or later lead to greater attention and the protection of the meaningful principle of this principle. The work also shows the dependence of all institutions of the acting Heads of State and Governments - some of whom are autocratic and while they sign international treaties, they do not care for their implementation on domestic level. One important fact is that the nomination process within the several institutions - especially the regional and subregional parliaments need to become democratized. Until today, the involved governments do have a strong influence on the nomination of the candidates and do not choose them according to their competence but rather according to their political opinion.

Most currently, voices argue that also the courts on subregional level - in particular the EAC Court - shall be competent to receive cases involving international crimes related matters. It was argued, that international crimes should be prosecuted in the region where the crimes were committed. Chief Justice Hassan Jallow argued that Art. 17 of the Rome Statute would form an ideal framework for a cooperation

\footnotetext{
1396 Scharfenberg (2014), 297.

1397 See: Art. 29 (1) of the 2015 Treaty establishing the Tripartite Free Trade Area.

1398 P. Richard, 'Afrika, Globalisierung und Menschenrechte', in R. Fornet-Betancourt \& H. Sandkühler (eds), Begründungen und Wirkungen von Menschenrechten im Kontext der Globalisierung, Dokumentation des VIII. Internationalen Seminars des Dialogprogramms Nord-Süd (2003), 153.

1399 Boré \& Henkel (2015), 19.
} 
with regional courts, stating that the ICC shall declare a case to be inadmissible where a national court has jurisdiction on the case. In order to ensure efficacy, Chief Justice Hassan Jallow stated that '[e]fforts underway to prepare a multilateral legal assistance treaty in this regard should be supported in order to facilitate cooperation in extradition, access to witnesses and evidence, transfer of prisoners and proceedings, and other matters. ${ }^{1400}$ However, at the time of writing, any details on the official extension of the EAC Courts' jurisdiction to human rights was not yet published.

It is finally desirable that the several subregional entities collaborate on a closer basis, which would lead to a creation of stronger economic blocs but also would empower the final consolidation of the RECs in order to reach the goals of the AEC Treaty. If than the Pan-African Parliament would be provided with legislative powers, as well as the African Court of Human Rights and Justice and if AU directives would apply directly within the Member States that AU could be developed from an international organization to a supranational organization. ${ }^{1401}$ Until the target of the AEC is reached, it is however possible that subregional courts and parliaments might push towards a greater protection of human rights and the rule of law on subregional level.

1400 Andriamananjara (2015).

1401 Viljoen (2007), 612. 


\section{Bibliography}

\section{Books}

Acharya, Rohini, Regional trade agreements: recent developments in Acharya, R (ed) Regional Trade Agreements and the Multilateral Trading Systems, 1st Edition, Cambridge University Press 2016.

Alston, Philip, The United Nations and human rights: a critical appraisal, 2nd. Edition, Oxford University Press 2018.

Alston, Philipp; Goodman, Ryan, International Human Rights - The Successor to International Human Rights in Context: Law, Politics and Morals, 2nd Edition, Oxford University Press 2012.

Amato, Giuliani, Milanesi, Enzo Moaveri, Pasquino, Gianfranco, Reichlin, Lucrezia (eds), The history of the European Union: constructing utopia, Hart, an imprint of Bloomsbury 2019.

Ankrah, Marvin N., Regionalism and Political Instability in West Africa:

Developments, Challenges and Prospects, Vol. 42, Schriften zur

Internationalen Politik, 1st Edition, Dr. Kovac Verlag 2013. 
Ankumah, Evelyn, The African Commission on Human and Peoples' Rights, 16th Edition, Kluwer Law International 1996.

Appiah, Kwame; Jr Gates; Henry L. (eds), Africana: The Encyclopedia of the African and African American Experience, Oxford University Press (1999).

Bado, Kangnikoné, Der Gerichtshof der Westafrikanischen

Wirtschaftsgemeinschaft (ECOWAS) als Verfassungsgericht, 1st Edition, Jus Internationale et Europaeum, Mohr Siebeck 2016.

Baricako, Germain, Introductory Preface in: Evars, Malcolm \& R. Murray, Rachel (eds), The African Charter on Human and Peoples' Rights: The System in Practice (2002), pp. 1-19.

Beyani, Chaloka, Protection of the Right to Seek and Obtain Asylum under the African Human Rights System, 12th Edition, Martinus Nijhoff Publishers 2013.

Bellelli, Robert, International Criminal Justice - Law and Practice from the Rome Statute to Its Review,1st Edition, Routledge 2016.

Boisson de Chazornes, Laurence, Interactions between Regional and Universal Organizatinos, 1st Edition, Brill I Nijhoff 2017.

Bortfeld, Matthias, Der Afrikanische Gerichtshof für Menschenrechte - Eine Untersuchung des Zusatzprotokolls zur Afrikanischen Charta für die Menschenrechte und die Rechte der Völker, Veröffentlichung aus dem Institut für Internationale Angelegenheiten der Universität Hamburg, 1st Edition, Nomos-Verlag 2004.

Braude, Wolfe, Regional Integration in Africa: Lessons from the East African Community, 1st Edition, South African Institute of International Affairs 2009.

Buthelezi, Sipho, Regional Integration in Africa: Prospects and Challenges for the 21st Century, 1st Edition, Ikhwezi Africa Publishing 2006.

Chidede, Talkmore, Legal Protection of Foreign Direct Investment - A Critical Assessment, 1st Edition, Anchor Academic Publishing 2016.

Chigara, Ben, Southern African Development Community land issues: towards a new sustainable land relations policy, 1st Edition, Routledge 2013.

COMESA Court of Justice, Medium term strategic plan of the COMESA Court of Justice 2008-2010, Common Market of Eastern and Southern Africa 2008.

Del Vecchio, Angela, International Courts and Tribunals - between globalisation and localims, 1st Edition, Eleven International Publishing 2013.

de Vries, Sybe, Bernitz, Ulf, Weatherill, Stephen (eds.), The EU Charter of Fundamental Rights as a binding instrument: five years old and growing, Hart Publishing 2015.

Ebobrah, Solomon T, International Human Rights Courts, in: Romano P.R, Karen, Alter J, Shany, Yuval (eds), The Oxford Handbook of International Adjudication (2013), pp. 225-249. 
Ellis, Mark S., Jalloh, Charles, The International Criminal Court in an effective global justice system, Edward Elgar Publishing 2016.

Englebert Pierre, K. C. Dunn, Kevin C., Inside African Politics, Lynne Rienner Publishers (2013).

Erasmus, Gerhard, Legal and institutional aspects of the Tripartite Free Trade Area: the need for effective implementation in: Hartzenberg, Trudi, Erasmus, Gerhard,McCarthy, Colin, Sandrey, Ron, Pearson, Mark, Jensen, Hans, Conjé, JB, Fundira, Taku, Kruger, Paul, Viljoen, Frans, Woolfrey, Sean (eds), The Tripartite Free Trade Area - towards a new African integration paradigm?, Tralac 2012, pp. 8-38.

Eze, Osita C., The African Charter on Rights and Duties and Enforcement Mechanisms, 6th Edition, Altius Verlag GmbH 2009.

Forere, Malebakeng, The Relationship of WTO Law and Regional Trade

Agreements in Dispute Settlement, 1st Edition, Global Trade Law Series, Wolters Kluver 2015.

Gathii, James T., African Regional Trade Agreements as Legal Regimes, 1st Edition, Cambridge University Press 2011.

Genge, Manelisi.; Kornegay, Francis; Rule, Stephan; African Union and PanAfrican Parliament: Working Papers, Vol. 63, Africa Institute of South Africa, 2000.

Hazlewood, Arthur, Economic integration: The East African experience, Heinemann, 1975.

Heyns, Christoph, A 'struggle approach' to human rights in Heyns, C, Stefiszyn, Karen (eds) Human Rights, Peace and Justice in Africa: A Reader, Vol. 1 ,Pretoria University Law Press 2006.

Hulse, Merran; van der Vleuten, Anna, Agent Run Amuck: The SADC Tribunal and Governance Roll-back, in: T. A. Börzel \& V. van Hüllen (eds), Governance Transfer by Regional Organizations, Governance and Limited Statehood Series, Palgrave Macmillan 2015, pp. 84-103.

Jemielniak, Joanna; Nielsen, Laura; Olsen, Palmer; Establishing Judicial Authority in International Economic Law, 1st Edition, Cambridge University Press 2016.

Lerner, Natán (2014). The UN Convention on the Elimination of All Forms of Racial Discrimination, Sijthoff \& Noordhoff International 1980.

Kaahwa, Wilbert, the Institutional Framework of the EAC in: Ugirashebuja, Emmanuel and Others (eds): East African Community Law, Institutional, Substantive, Comparative EU Aspects, 1st Edition, Brill, 2017, pp. 43-78.

Kaczorowska, Alina, Public International Law, 5th Edition, Routledge 2015.

Kane, Ibrahima, The African Commission on Human and Peoples' Rights and the New Organs of the African Union in: Wolgemuth, Lennart; Sall Ebrima (eds), Human Rights, Regionalism and the Dilemmas of Democracy in Africa, CODESRIA, Senegal 2006, pp. 154-170. 
Kane, Ibrahima, Motala, Ahmed, The Creation of a New African Court of Justice and Human Rights in Evans, Malcolm, Murray, Rachel (eds) The African Charter on Human and Peoples' Rights - The System in Practice, 1986-2006, Vol. 2, Cambridge University Press 2008, pp. 406-440.

Kennedy, Gastorn; Sippel, H.; Wanitzek, U., Processes of legal integration in the East African Community, 1st Edition, Dar es Salaam Press, 2011.

Killander, Magnus, The African Commission on Human and Peoples' Rights in Ssenyonjo, Manisuli (ed) The African Regional Human Rights System 30 Years after the African Charter on Human and Peoples' Rights, 1st Edition, Martinus Nijhoff Publishers 2012, pp. 235-248.

Kleis, Jörg, African Regional Community Courts and their Contribution to Continental Integration, 1st Edition, Nomos-Verlag 2016.

Kufour, Kofi O., The African Human Rights System - Origin and Evolution, 1st Edition, PALGRAVE MACHMILLAN, 2010.

Kyemba, Henry, State of Blood: The Inside Story of Idi Amin, Corgi Books 1977.

Lehmann, Julia, Wirtschaftsintegration und Streitbeilegung außerhalb Europas, Völkerrecht und Außenpolitik, 1st Edition, Nomos Verlagsgesellschaft 2003.

Mangeni, Francis, The case for the COMESA-EAC-SADC: tripartite arrangement, Common Market for Eastern and Southern Africa, 1st Edition, 2012.

Maonera, Felix, Zimbabwe: which way: COMESA or SADC customs union?, 1st Edition, Trade and Development Studies Centre 2007.

Martin, Guy, African Political Thought, 1st Edition, Palgrave Macmillan 2012.

Masinde, Wanyama Masinde and Omolo, Christopher Otieno, The Road to East African Integration in: Emmanuel Ugirashebuja, John Eudes Ruhangisa, Tom Ottervanger, Armin Cuyvers (eds), East African Community Law: Institutional, Substantive and Comparative EU Aspects, 1st Edition, Bill 2017, pp. 1-21.

Mataranyika, Chamunorwa, Leadership orientation workshop for the National Assembly of Mauritius, Windhoek, SADC Parliamentary Forum 2008.

Matyszak, Derek, The dissolution of the SADC Tribunal, 1st Edition, Research and Advocacy Unit 2011.

Mangandize, Ottilia, du Plessis, Anton, The ICC and the AU in Stahn, Carsten (ed), The Law and Practice of the International Criminal Court, 1st Edition, Oxford University Press 2015, pp. 65-83.

Mireille Affa' a Mindizie, The African Commission on Human and Peoples' Rights in: Akokpari, John, Zimbler, Daniel Shea (eds), Africa’s Human Rights Architecture, 1st Edition, Jacana Media (Pty) Ltd. 2008, pp. 204-232.

Morsink, Johannes, The Universal Declaration of Human Rights, Origins, Drafting and Intent, 1st Edition, University of Philadelphia Press 1999. 
Mshomba, Richard B., Economic Integration in Africa - The East African Community in Comparative Perspective, 1st Edition, Cambridge University Press, 2017.

Mugwanya, George William, Human Rights in Africa - Enhancing Human Rights Through the African Regional Human Rights System, 1st Edition, Transnational Publishers, Inc. 2003.

Muigai, Githu, From the African Court on Human and Peoples' Rights to the African Court of Justice and Human Rights in: Ssenyonjo, Manisuli (ed), The African Regional Human Rights System - 30 Years after the African Charter on Human and Peoples' Rights, 1st Edition, Martinus Nijhoff 2012, pp. 265-282.

Murphy, Sean D., Principles of International Law, 3rd Edition, West Academic Publishing, 2018.

Murray, Rachel, Long, Debra, The Implementation of the Findings of the African Commission on Human and Peoples' Rights, 1st Edition, Cambridge University Press 2015.

Murray, Rachel, Malcolm, Evans, The State Reporting Mechanism of the African Charter in: Murray, Rachel, Malcolm, Evans, The African Charter on Human and Peoples Rights - The System in Practice, 1986-2006, 1st Edition, Cambridge University Press 2006, pp. 49-74.

Nathan, Laurie, Community of insecurity: SADC's struggle for peace and security in Southern Africa, The International Political Economy of New Regionalisms Series, 1st Edition Routledge 2016.

Ndulo Muna, The African Commission and Court under the African Human Rights System: Towards an Effective Human Rights Architecture? in Akokpari, J, Zimbler, Daniel Shea (eds) Africa's Human Rights Architecture, 1st Edition, Jacana Media (Pty) Ltd. 2008), pp. 182-203.

Nsereko, Daniel D.N., The International Criminal Court and Africa in Sssenyonio, Manisuli (ed) The African Regional Human Rights System; 30 Years after the African Charter on Human and Peoples' Rights, 1st Edition, Martinus Nijhoff Publishers 2012, pp. 337-354.

Nwankwo, Chidebe, Legitimation of the Economic Community of West African States (ECOWAS): A Normative and Institutional Inquiry, Brunel University 2014.

Ochwada, Joseph, Principles of Operation and Development Strategies in the East African Community in: Kennedy Gastorn, Harald Sippel and Ulrike Wanitzek (eds), Processes of Legal Integration in the East African Community, Dar es Salaam University Press 2011, pp. 67-82.

Okoth, Assa, A history of Africa, 1st Edition, Heinemann 1998.

Oppong, Richard F., Legal Aspects of Economic Integration in Africa, 1st Edition, British Columbia 2011. 
Ott, Jens, Das Europäische Parlament als Parlament, Europäische

Hochschulschriften Reihe 2, Peter Lang 2016.

Peers, Steve, Ward, Angela (eds), The EU Charter and of Fundamental Rights:

politics, law and polity. 1st Edition, Oxford: Hart Publishing 2004.

Peter, Chris, M., Fighting Impunity - African States and the International

Criminal Court, in: Ankumah, Evelyn A. (ed), The International Criminal

Court and Africa - One decade on, 1st Edition, Intersentia 2016, pp. 1-62.

Posner, Eric, The Twilight of Human Rights Law, Oxford University Press 2014.

Richard, Philippe, Afrika, Globalisierung und Menschenrechte in: Fornet-

Betancourt, Raúl, Sandkühler, Hans Jorg (eds), Begründungen und

Wirkungen von Menschenrechten im Kontext der Globalisierung,

Dokumentation des VIII. Internationalen Seminars des Dialogprogramms

Nord-Süd, IKO -Verlag für Interkulturelle Kommunikation 2003, pp. 144-164.

Ruppel, Oliver, C, Land Issues before the Southern African Development

Community Tribunal: a case for human rights? in: Chigara, Ben (ed),

Southern African Development Community land issues: towards a new

sustainable land relations policy, 1st Edition, Routledge 2013, pp. 87-113.

Ruppel, Oliver C., Regional economic communities and human rights in East and Southern Africa in: Bösl, Anton, Diescho, Joseph (eds), Human Rights in Africa, Legal Perspectives on their Protection and Promotion, KonradAdenauer-Stiftung, Auslandsbüro Namibia und Angola 2009, pp. 275-318.

Sadat, Leila Nadya; Cohen, B., Impunity through Immunity in: Ankumah, Evelyn A. The International Criminal Court and Africa - One Decade On, Intersentia 2016, pp. 101-124.

Scharfenberg, Jan, Die regionalen Gerichtshöfe der Südafrikanischen Entwicklungsgemeinschaft (SADC) und der Ostafrikanischen Gemeinschaft (EAC), 1st Edition, Europäische Handschulschriften, Peter Lang GmbH 2014.

Shelton, Dinah, Regional Protection of Human Rights, 1st Edition, Oxford University Press 2008.

Shelton, Dinah, Remedies in International Human Rights Law, 3rd Edition, Oxford University Press 2015.

Southern African Development Community Parliamentary Forum, Election Observation Mission Report for the 2012 Angola general elections, SADC Parliamentary Forum 2012.

Southern African Development Community Parliamentary Forum, Election Observation Mission Report for the 2002 Presidential Elections of Zimbabwe, SADC Parliamentary Forum between 2002 and 2004. 
Southern African Development Community, Parliamentary Forum, Election Observation, Statement on the Elections in South Africa 2004, SADC Parliamentary Forum 2004.

Southern African Developing Community, Parliamentary Forum, Election Observation Statement on the Presidential and Parliamentary Elections in Malawi 2004, SADC Parliamentary Forum 2004.

Southern African Development Community Parliamentary Forum, Strategic Plan 2011-2015, 2011.

Suret-Canale, Jean, French Colonialism in Tropical Africa, 1900-1945, 1st Edition, Universe Pub 1961.

Swart, Mia, Towards a Multi-Layered System of International Criminal Justice in Ankumah, Evelyn A. (ed) The International Criminal Court - One Decade On 1st Edition, Intersenia 2016.

Umbricht, Victor H., Multilateral Mediation, Practical Experiences and Lessons, 1st Edition, Springer 1989.

Umozurike, U.O., The African Charter on Human and Peoples' Rights, 2nd Edition, The Hague 1997.

van Aaken, Anne, Motoc, Iulia, The European Convention on Human Rights and general international law, Oxford University Press 2015.

Viljoen, Frans, International Human Rights Law in Africa, 1st Edition, Oxford University Press 2007.

Wade, Martin J., Russel, William F., The Short Constitution, 1st Edition, American Citizens Publishing Co. 1921.

Weiss, Thomas G.; Daws, Sam (eds.) The Oxford Handbook on the United Nations. 2nd Edition, Oxford University Press 2018.

Zimbler, Daniel Shea; Africa: Towards an Effective Human Rights Architecture? in Akokpari, John, Zimbler, Daniel Shea (ed), Africa's Human Rights Architecture, 1st Edition, Jacana Media (Pty) Ltd. 2008, pp. 284-293.

\section{Law journal articles}

Abaya, Miriam, No Place for Immunity: the Arguments against the African Criminal Court's Article, 30 (2016) Temple International \& Comparative Law Journal, 46BIS, pp. 189-223.

Abebe, Daniel, Does International Human Rights Law in African Courts Make a Difference (2016), 56, Va J Int'l L, pp. 527-584.

Adede, A.O., International Human Rights Law: Lessons for Treaty-making and Implementation (1995), 3, African Yearbook of International Law, pp. 99-118. 
Adeleke, Olufolahan, Revisiting locus standi and the grounds for jurisdiction of the SADC Tribunal in United Republic of Tanzania v Ciexpan (Mauritius) Ltd., Cimexpan Zanzibar Ltd. \& Ajaye Jogoo, SADC (T) 01/2009 (2011), 1, SADC Law Journal, pp. 207-210.

Adjolohoun, Horace S., The ECOWAS Court as a Human Rights Promoter: Assessing Five Years' Impact of the Koraou Slavery Judgment Part A: Articles (2013), 31, Neth Q Hum Rts, pp. 342-371.

Afadameh-Adeyemi, Ashimizo, Barry Gondo \& 8 Others v The Republic of Zimbabwe, SADC (T) 05/2008 (2011), 1, SADC Law Journal, pp. 203-206.

Ajulo, Sunday B., Law, Language and International Organisation in Africa: The Case of Ecowas (1985), 29, J Afr L, pp. 1-24.

Allan, Trevor R.S. (1998), "Procedural Fairness and the Duty of Respect", Oxford Journal of Legal Studies, 18 (3), pp. 497-515.

Ali, Abdi J., The Admissibility of Subregional Courts' Decisions before the African Commission or African Court (2012), 6, Mizan L Rev, pp. 241-272.

Alter, Karen, J., Gathii, James T., Helfer, Laurence R. McAllister, Jaqueline R., Backlash against international courts in West, East and Southern Africa: causes and consequences (2016), 27, EJIL, pp. 293-328.

Alter, Karen, J., Helfer, Laurence R., McAllister, Jaqueline R., A New International Human Rights Court for West Africa: The Ecowas Community Court of Justice (2013), 107, Am J Int'l L, pp. 737-779.

Amoah, Philipp, The African Charter on Human and Peoples' Rights - An Effective Weapon for Human Rights Shorter Article (1992), 4, Afr J Int'l \& Comp L, pp. 226-241.

Aniekwu, Nkolika I., The Additional Protocol to the African Charter on Human and Peoples' Rights: Indications of Capacity for African Municipal Systems (2009), 13, Law Democracy \& Dev, pp. 22-35.

Assefa, Ayalew G., Advancing Children's Rights in Africa: The Role of the African Children's Charter and Its Monitoring Body (2014), 2, Mekelle U LJ, pp. 66-101.

Atik, Jeffry; Democratizing the WTO Symposium: Global Trade Issues in the New Millenium (2001), 33, Geo Wash Int'l L Rev. pp. 451-472.

Bekker, Gina, The African Commission on Human and Peoples' Rights and Remedies for Human Rights Violations (2013), 13, Hum Rts L Rev, pp. $499-528$.

Bekker, Gina, The African Court on Human and Peoples' Rights: safeguarding the interests of African states (2007), 51, Journal of African Law, pp. 151-172.

Berna, Maria B., The Cultural Factor and Women's Rights within the African Charter on Human and Peoples' Rights and Its Protocol (2015), 2015, Law Annals Titu Maiorescu U, pp. 11-26. 
Beukes, Margaret; Zimbabwe in the Dock: the Southern African Development Community (SADC) Tribunal's First Decision Foreign Judicial Decisions (2008), 33, S. Afr. Y.B. Int'L, pp. 228-243.

Breytenback, Willie; Democracy in the SADC region (2002), 11, African Security Review, pp. 87-102.

Buergenthal, Thomas, Human Rights in: Wolfrum, Rüdiger (ed), Max Planck Encyclopedia of Public International Law (2007), paras 1-26.

Charleswoth, Hilary, Universal Declaration of Human Rights (1948) in: Wolfrum Rüdiger (ed), Max Planck Encyclopedia of Public International Law (2007), paras 1-20.

Chigara, Ben, Introductory note to a Southern African Development Community (SADC) Tribunal: Mike Campbell (PVT) and Others v. Republic of Zimbabwe (2009), International Legal Materials, pp. 530-533.

Chigara, Ben, What Should a Re-constituted Southern African Development Community (SADC) Tribunal Be Mindful of to Succeed? (2012), 81, Nordic Journal of International Law, pp. 341-377.

Chirwa, Danwood, M., The Merits and Demerits of the African Charter on the Rights and Welfare of the Child Children's Rights in Africa (2002), 10, Int'l J Child Rts, pp. 157-178.

Chitimira, Howard, Mokone, Pontsho,; The Functions of Selected Human Rights Institutions and Related Role-Players in the Protection of Human Rights in Zimbabwe (2016), 19, Potchefstroom Elec LJ, pp. 1-40.

Cole, Rowland, J. V., Africa's Relationship with the International Criminal Court: More Political than Legal (2013), 14, Melbourne Journal of International Law, pp. 670-698.

Cole, Rowland J. V., The African Court on Human and Peoples' Rights: Will Political Stereotypes form an Obstacle to the Enforcement of its Decisions? (2010), 43, Comp \& Int'l LJ S Afr, pp. 23-45.

Cole, Rowland J.V., The Emerging Jurisprudence of the African Court on Human and Peoples' Rights - African Commission on Human and Peoples' Rights v Great Socialist People's Libyan Arab Jamahiriya (Order for Provisional Measures) Note (2012), 14, U Botswana LJ, pp. [i]-154.

Cowell, Frederick, The Death of the Southern African Development Community Tribunal's Human Rights Jurisdiction (2013), 13, Hum Rts L Rev, pp. 153-165.

Cowling, Michael, African Union - An Evaluation, The Notes and Comments (2002), 27, S Afr YB Int'l L, pp. 193-205.

Crawford, James, Grant, Thomas, Exhaustion of Local Remedies, in: Wolfrum, Rüdiger (ed), Max Planck Encyclopedia of Public International Law (2007).

Davel, Tyrnie, The African Charter on the Rights and Welfare of the Child, Family Law and Children's Rights (2002), 35, De Jure, pp. 281-296. 
De Butler, Israel Jesus, Securing human rights in the face of international integration (2011), 60, International \& Comparative Law Quarterly, pp. 125-165.

Demeke, Tsegaye, The New Pan-African Parliament: Prospects and Challenges in View of the Experience of the European Parliament (2004), 4, Afr Hum Rts LJ, pp. 53-73.

Dinkopila, Bonolo R., The Pan-African Parliament and African human rights actors, civil society and national human rights institutions: the importance of collaboration (2013), 13, Afr Hum Rts LJ, pp. 302-323.

Dirar, Luwam, Common Market for Eastern and Southern African Countries: multiplicity of membership issues and choices (2010), 18, African Journal of International and Comparative Law, pp. 217-232.

Dlamini, C.R.M., Towards a Regional Protection of Human Rights in Africa: The African Charter on Human and Peoples Rights (1991), 24, Comp \& Int'l LJ S Afr, pp. 189-203.

Doebbler, Curtis F. J., A Complex Ambiguity: The Relationship between the African Commission on Human and Peoples' Rights and Other African Union Initiatives Affecting Respect for Human Rights Symposium: The African Union and the New Pan-Africanism: Rushing to Organize or Timely Shift (2003), 13, Transnat'l L \& Contemp Probs, pp. 7-32.

Ebobrah, Solomon T., A Critical Analysis of the Human Rights Mandate of the ECOWAS Court of Justice (2008), 54, J Afr L, pp. 1-25.

Ebobrah, Solomon T., Human rights developments in African sub-regional economic communities during 2009 (2010), 2, Afr Hum Rts LJ, pp. 233-264.

Ebobrah, Solomon T., Human rights developments in African sub-regional economic communities during 2010 (2011), 1, Afr Hum Rts LJ, pp. 216-250.

Ebobrah, Solomon T.; Human rights developments in African sub-regional economic communities during 2011 (2012), Afr Hum Rts LJ, pp. 223-253.

Ebobrah, Solomon T.; Human rights developments in African sub-regional economic communities during 2012 (2013), 2, Afr Hum Rts LJ, pp. 178-223.

Ebobrah, Solomon T., Litigating Human Rights Before Sub-Regional Courts in Africa: Prospects and Challenges (2009), 17, African Journal of International and Comparative Law, pp. 79-101.

Ebobrah, Solomon T., Tackling threats to the existence of the SADC Tribunal: A Critique of perilously ambiguous provisions in the SADC Treaty and the Protocol of the SADC Tribunal (2010), 4, Malawi Law Journal, pp. 199-213. 
Ekhator, Eghosa O., Improving access to environmental justice under the African Charter on Human and Peoples' Rights: the roles of NGOs in Nigeria (2014), 22, Afr J Int'l \& Comp L, pp. 63-79.

Elias, T. O., The Charter of the Organization of African Unity (1965), 59, Am J Int'l L, pp. 243-267.

El-Obaid, EOA; Appiagyei-Atua, Kwadwo Human Rights in Africa - A New

Perspective on Linking the Past to Present, McGill Law Journal (1996), 41, pp. 819-854.

Emmanuel, Jason; The International Criminal Court and Sovereignty: What Does Kenyatta Mean for the Future of the ICC, Transat'l L. \& Contemp. Probs. (2014), 24, pp. 133-160.

Ex-Commissioner Moleleki Mokama in C. Odinkalu, Interview with Moleki Mokama, Interights 1992, cited in Murray, Rachel, Decisions by the African Commission on Individual Communications under the African Charter on Human and Peoples' Rights, The International and Comparative Law Quarterly, op. cit. 414 n. 20.

Frowein, Jochen.A., United Nations (UN) (2013), in: Wolfrum, Rüdiger (ed), Max Planck Encyclopedia of Public International Law, paras 1-47.

Gathii, James, T. Mission Creep Or a Search for Relevance: The East African Court of Justice's Human Rights Strategy (2013), 24, Duke J Comp \& Int'l L, pp. 249-296.

Gathii, James T., Sub-Regional Court or Employment Tribunal? The Legacy and Legitimacy of the COMESA Court of Justice (2015), No. 2015-012, Loyola University of Chicago School of Law Research Paper pp. 1-29.

Gevers, Christopher, du Plessis, Max, Another Stormy Year for the International Criminal Court and its Work in Africa Notes and Comments (2010), 35, S Afr YB Int'l L, pp. 163-180.

Godwin-A Hart, Sotonye, Integrating Trade and Human Rights in West Africa: An Analysis of the Ecowas Experience Discussion Pieces (2012), 32, Windsor Rev Legal \& Soc Issues, pp. 57-90.

Gondwe, Michael, From PTA to COMESA: The Quest for Sub-Regional

Economic Integration in Eastern and Southern Africa (1998), 6, African Yearbook of International Law, pp. 3-22.

Grossmann, Claudio M., Inter-American Commission on Human Rights (IACommHR), in: Wolfrum, Rüdiger (ed), Max Planck Encyclopedia of Public International Law (2007), paras. 1-41.

Gumedze, Sabelo, The Nepad and Human Rights Current Developments (2006), 22, S Afr J on Hum Rts, pp. 144-172.

Hafez, Zakir, Weak Discipline: GATT Article XXIV and the Emerging WTO Jurisprudence on RTAs (2003), 79, ND L Rev, pp. 879-920. 
Hammed, Hanafi, A., Kabo, Sarinus E., African Peer Review Mechanism and Crisis of Good Governance in Africa (2013), 19, JL Pol'y \& Globalization, pp. [i]-25.

Hansungule, Michelo, The African Charter on Human and Peoples Rights: a critical review (2000), 8, African Yearbook of International Law, pp. 265-331.

Heyns, Christof, Some Thoughts on Challenges Facing the International Protection of Human Rights in Africa Column (2009), 27, Neth Q Hum Rts, pp. 447-450.

Heyns, Christof; Baimu, Evarist; Killander, Magnus, The African Union (2003), 46, German YB Int'l L, pp. 252-283.

Hill, Christopher, Regional co-operation in southern Africa (1983), 82(327), African Affairs, pp. 215-293.

Holden, James, P.J., Economic Community of West African States (ECOWAS): A Legal Perspective on Its Present Status and Prospects Africa - Part II: General Studies - Chapter Two 6a, Mod Legal Sys Cyclopedia, pp. 6A.220.221226A.220.230.

Ibrahim, Abadir M., African Commission on Human and Peoples' Rights and Human Rights Education: Much Buzzing, Still No Honey, The (2010), 35, S Afr YB Int'l L, pp. 111-132.

Igwe, Chikeziri S., The ICC's Favourite Customer: Africa and International Criminal Law (2008), 41, Comp \& Int'l LJ S Afr, pp. 294-323.

Imoedemhe, Ovo, Unpacking the tension between the African Union and the International Criminal Court: the way forward (2015), 23, Afr Hum Rts LJ, pp. 74-105.Jonas, Obonye, Neutering the SADC Tribunal by Blocking Individuals' Access to the Tribunal, (2013), International Human Rights Law Review, pp. 294-321.

Katundu, Mangasini, Tanzania’s Constitutional Reform Predicament and the Survival of the Tanganyika and Zanzibar Union, (2015), 8(3), The Journal of Pan African Studies, pp. 104-118.

Kayihura, Desiré, Parallel jurisdiction of courts and tribunals: the COMESA Court of Justice perspective (2010), 36, Commonwealth Law Bulletin, pp. 583-592.

Keppler, Elise, Managing setback for the International Criminal Court in Africa (2012), 56, J Afr L, pp. 1-14.

Killander, Magnus, The African Peer Review Mechanism and Human Rights: The First Reviews and the Way Forward (2008), 30, Hum Rts Q, pp. 41-75.

Kindiki, Kithure, The proposed integration of the African Court of Justice and the African Court of Human and Peoples' Rights: legal difficulties and merits (2007), 15, Afr J Int'l \& Comp L, pp. 138-146. 
Krajewski, Markus, International Organizations or Institutions, Democratic Legitimacity, in R. Wolfrum (ed), Max Planck Encyclopedia of Public International Law 2007, paras 1-25.

Kufour, Kofi Oteng, Securing Compliance with the Judgments of the ECOWAS Court of Justice (1996), 8, Afr J Int'l \& Comp L, pp. 1-11.

Kufour, Kofi Oteng, The collapse of the Organization of African Unity: lessons from economics and history (2005), 49, J Afr L, pp. 132-144.

Kuteesa, Anette, East African Regional Integration: Challenges in Meeting the Convergence Criteria for Monetary Union: A Survey (2012), 4, International Journal of Economics and Finance, pp. 147-160.

Levitt, Jeremy I., Beyond Borders: Martin Luther King, Jr., Africa, and Pan Africanism A Festschrift in Honor of Professor Henry J. Richardson III (2017), 31, Temp Int'l \& Comp LJ, pp. 301-324.

Lloyd, Amanda, Evolution of the African Charter on the Rights and Welfare of the Child and the African Committee of Experts: Raising the Gauntlet Children's Rights in Africa (2002), 10, Int'l J Child Rts, pp. 179-198.

Lokulo-Sodipe, J.O., Osuntogun, A. J., The Quest for a Supranational Entity in West Africa: Can the Economic Community of West African States Attain the Status (2013), 16, Potchefstroom Elec LJ, pp. 254-291.

Magliveras, Konstantinos, Naldi, Gino, The ICC Addresses Non-Cooperation by States Parties: The Malawi Decision (2013), 6, Afr J Legal Stud, pp. 137-152.

Magliveras, Konstantinos D., Naldi, Gino J., The Pan-African Parliament of the African Union: An Overview (2003), 3, Afr Hum Rts LJ, pp. 222-234.

Malanczuk, Peter, Association of Southeast Asian Nations (ASEAN), in: Wolfrum, Rüdiger (ed), Max Planck Encyclopedia of Public International Law (2007), paras 1-88.

Manby, Bronwen, The African Union, NEPAD, and Human Rights: The Missing Agenda (2004), 26, Hum Rts Q, pp. 983-1027.

Mangu, Andre Mabata B., What Future of Human and Peoples' Rights under the African Union, New Partnership for Africa's Development, African PeerReview Mechanism and the African Court (2004), 29, S Afr YB Int'l L, pp. 136-163.

Mangu, Andre Mabata B., African Peer-Review Mechanism and the Promotion of Democracy and Good Political Governance in Africa, The Conference Paper (2007), 32, S Afr YB Int'l L, pp. 2-24.

Mapuva, Jephias; Muyengwa-Mapuva, Loveness, The SADC Regional Bloc: What Challenges and Prospects for Regional Integration (2014), 18, Law Democracy \& Dev, pp. 22-36.

Marauhn, Thilo, North Atlantic Treaty Organization, in: R. Wolfrum Rüdiger (ed), Max Planck Encyclopedia of Public International Law (2007), paras $1-70$. 
Matasi, Martin, Bröhmer Jürgen, The Proposed International Criminal Chamber section of the African Court of Justice and Human Rights: A legal analysis, 37 S. Afr. Y.B. Int'l L., pp. 248-268.

Meckler, Shane, A Human Rights Monster that Devoured No One: The FarReaching Impact of Dismantling the SADC Tribunal Notes (2015), 48, NYU J Int'l L \& Pol, pp. 1007-1038.

Mhone, Kandako, Law as a Factor for Regional Integration: SADCC: Problems and Prospects (1991), 24(3), The Comparative and International Law Journal of Southern Africa, pp. 379-385.

Mkandawire, MCC, The SADC Tribunal perspective on enforcement of judgments: state support and cooperation (2010), 3, Commonwealth Law Bulletin, pp. 567-573.

Moyo, Admark, Defending human rights and the rule of law by the SADC Tribunal: Campbell and beyond (2009), 9, African Human Rights Journal, pp. 590-614.

Mubangizi, John, O'Shea, Andreas, African Court on Human and Peoples' Rights, An Notes and Comments (1999), 24, S Afr YB Int'l L, pp. 256-270.

Müller, Franziska, Storming, Norming, Performing: Implications of the financial crisis in Southern Africa (2010), Goettingen Journal of International Law, pp. 168-189.

Munya, Mweti P., The Organization of African Unity and Its Role in Regional Conflict Resolution and Dispute Settlement: A Critical Evaluation (1998), 19, B C Third World L J, pp. 537-592.

Murray, Rachel, Serious or Massive Violations under the African Charter on Human and Peoples' Rights: A Comparison with the Inter-American and European Mechanisms Part A (1999), 17, Neth Q Hum Rts, pp. 109-134.

Murungi, Nkatha L.; Gallinetti, Jacqui, The Role of Sub-Regional Courts in the African Human Rights System (2010), 7, International Journal on Human Rights, pp. 119-143.

Murungu, Cchacha B., Towards a Criminal Chamber in the African Court of Justice and Human Rights (2011), 9, J Int'l Crim Just, pp. 1067-1088.

Mutua, Makau, The African Human Rights Court: A Two-Legged Stool, Hum. Ts. Q. (1999), pp. 342-363.

Mwenda, Kenneth K., Legal Aspects of Regional Integration: Comesa and Sadc on the Regulation of Foreign Investment in Southern and Eastern Africa (1997), 9, Afr J Int'l \& Comp L, pp. 324-348.

Mwenda, Kenneth K., The Common Market for Eastern and Southern Africa (COMESA) and the COMESA Court: Immunity of an international organisation from legal action (2009), 6, Miskolc Journal of International Law, pp. 60-83. 
Naldi, Gino, J; Magliveras, Konstantinos D., The African Court of Justice and Human Rights: A Judicial Curate's Egg (2012), 9, Int'l Org L Rev, pp. 383-450.

Naldi, Gino J, Magliveras, Konstantinos D., The ASEAN Human Rights Declaration (2014), 3, Int'l Hum Rts L Rev, pp. 183-208.

Nathan, Laurie, Solidarity triumphs over democracy - the dissolution of the SADC Tribunal (2011), Development Dialogue December 2011, The United Nations and Regional Challenges, pp. 123-136.

Nathan, Laurie, The Disbanding of the SADC Tribunal: A Cautionary Tale (2013), 35, Hum Rts Q, pp. 870-892.

Ndulo, Muna, Harmonisation of trade laws in the African Economic Community (1993), 42, International \& Comparative Law Quarterly, pp. 101-118.

Neumann, Gerald L., American Convention on Human Rights (1969), in: Wolfrum, Rüdiger (ed), Max Planck Encyclopedia of Public International Law (2008), paras 1-44.

Neumann, Gerald L., Inter-American Court of Human Rights (IACtHR), in: Wolfrum, Rüdiger (ed), Max Planck Encyclopedia of Public International Law (2007), paras 1-48.

Ng'ong'ola, Clement, The Reconstitution of the Southern African Development Community: Some International Trade Law Perspectives (2000), 117, South African Law Journal, pp. 256-283.

Ngolo, Emely, W., Analysing the Future of International Criminal Justice in Africa: A Focus on the ICC (2016), 1, Strathmore L Rev, pp. 99-122.

Nkhata, Mwiza J., The Role of Regional Economic Communities in Protecting and Promoting Human Rights in Africa: Reflections on the Human Rights Mandate of the Tribunal of the Southern African Development Community (2012), 20, Afr J Int'l \& Comp L, pp. 87-109.

Nmehielle, Vincent O., The African Union and African Renaissance: A New Era for Human Rights Protection in African? (2003), Singapore Journal of International and Comparative Law, pp. 412-446.

Nmehielle, Vincent O., Seven Years in Business: Evaluating Developments at the African Court on Human and Peoples' Rights (2013), 17, Law Democracy \& Dev, pp. 317-341.

Nsibirwa, Martin S., A Brief Analysis of the Draft Protocol to the African Charter on Human and People's Rights on the Rights of Women (2001), 1, Afr Hum Rts LJ, pp. 40-63.

Nwauche, E. S., Enforcing ECOWAS Law in West African National Courts (2011), 55, J Afr L, pp. 181-202.

Nwauche, E. S., The ECOWAS Community Court of Justice and the horizontal application of human rights (2013), 13, African Human Rights Journal, pp. 30-54. 
Oetheimer, Mario Palomares, Guillem Cano, European Court of Human Rights (ECtHR), in: Wolfrum, Rüdiger (ed), Max Planck Encyclopedia of Public International Law, paras 1-77.

Ocran, Christine, Protocol to the African Charter on Human and Peoples' Rights on the Rights of Women in Africa Recent Developments (2007), 15, Afr J Int'l \& Comp L, pp. 147-152.

Oder, Judy, The African Court on Human and Peoples' Rights' order in respect of the situation in Libya: A watershed in the regional protection of human rights? (2011), 2, Afr Hum Rts LJ, pp. 495-510.

Oduor, Maurice, Resolving Trade Disputes in Africa: Choosing between Multilateralism and Regionalism: The case of COMESA and WTO (2005), 13, Journal of International Comparative Law, pp. 177-218.

Ojomo, Edefe, Competing Competences in Adjudication: Reviewing the Relationship between the ECOWAS Court and National Courts (2014), 7, Afr J Legal Stud, pp. 87-122.

Oke, Yemi, Substitute for the United Nations? Extending frontiers of the North Atlantic Treaty Organisation and implications for African unity (2013), 21, Afr J Int'l \& Comp L, pp. 120-141.

Okere, B.O., The Protection of Human Rights in Africa and the African Charter on Human and Peoples' Rights: A Comparative Analysis with the European and American Systems (1984), 6, Hum Rts Q, pp. 141-159.

Okolo, Julius E., Obstacles to Increased Intra-ECOWAS Trade Miscellany (1988), Int'l J, pp. 171-214.

Okolo, Julius E., ECOWAS Regional Cooperation Regime, German Yearbook of International Law (1989), pp. 111-137.

Oloka-Onyango, J., Ugadama, D., Human Rights as the primary objective of international trade, investment and finance policy and practice, Working Paper, Submitted in accordance with sub-Commission Resolution 1998/12' (17 June 1999) UN Doc E/Cn.4/Sub.2/1999 11.

Olonsakin, Funmi, Aning, Emmanuel K.-, Humanitarian Intervention and Human Rights: The Contradictions in ECOMOG, 3 Int J Hum Rt 1 (1999), pp.16-39.

Olowu, Dejo, Protecting Children's Rights in Africa: A Critique of the African Charter on the Rights and Welfare of the Child Children's Rights in Africa (2002), 10, Int'l J Child Rts, pp. 127-136.

Olufolahan, Adelele; Revisiting locus standi and the grounds for jurisdiction of the SADC Tribunal in United Republic of Tanzania v. Ciexpan (Mauritius) Ltd., Cimexpan Zanzibar Ltd. \& Ajaye Jogoo, SADC (T) 01/2009 (2011), 1, SADC Law Journal, pp. 207- 210.

Oluoch, Wauna LO., Legitimacy of the East African Community (2009), 53, Journal of African Law, pp. 194-221. 
Onoria, Henry, Locus standi of individuals and non-state entities before regional economic integration judicial bodies in Africa (2010), 18, African Journal of International and Comparative Law, pp. 143-169.

Oppong, Richard F., The Higher Court of Ghana Declines to Enforce an ECOWAS Court Judgment Recent Developments (2017), 25, Afr J Int'l \& Comp L, pp. 127-136.

Ovrawah, O. Anukpe, Harmonisation of Laws within the Economic Community of West African States (ECOWAS) (1994), 6, Afr J Int'l \& Comp L, pp. 76-92.

Pallotti, Arrigo, Lost in transition? CCM and Tanzania's faltering Democratisation process, (2017), 35, Journal of Contemporary African Studies, pp. 544-564.

Pedersen, Morten, P., Standing and the African Commission on Human and Peoples' Rights [article] (2006), 6, Afr Hum Rts LJ, pp. 407-422.

Phooko, M.R., No longer in suspense; clarifying the human rights jurisdiction of the SADC Tribunal (2015), 18, Potchefstroom Electronic Law Journal, pp. 531-567.

Picker, Colin B.; Regional Trade Agreements v. The WTO: A Proposal for Reform of Art. XXIV to Counter this Institutional Threat (2005), 26, U Pa J Int'l Econ L, pp. 267-320.

Polymenopoulou, Eleni, African Court on Human and Peoples' Rights, African Commission on Human and Peoples' Rights v Great Socialist People's Libyan Arab Jamahiriya, Order for Provisional Measures 25 March 2011 Current Developments: International Courts and Tribunals: Section I (2012), 61, Int'l \& Comp LQ, pp. 767-775.

Possi, Ally, East African Court of Justice: Towards Effective Protection of Human Rights in the East African Community, The (2013), 17, Max Planck Yearbook of United Nations Law (Brill), pp. 173-196.

Possi, Ally, Striking a Balance between Community Norms and Human Rights: The Continuing Struggle of the East African Court of Justice (2015), 15, Afr Hum Rts LJ, pp. [i]-223.

Quirico, Ottavio, General Principles of International Criminal Law and their Relevance to Africa (2009), 17, African Yearbook of International Law, pp. 139-163.

Ramolefe, AMR, Sanders, AJG; The Structural Pattern of African Regionalism, Comparative and International Law Journal of Southern Africa, Vol. 4, Issue 2 (1972), pp. 155-192.

Rosalind, H. Thomas, The World Trade Organisation and Southern African trade relations (1991), 3, Law, Democracy and Development, pp. 105-121.

Rudolf, Beate, United Nations Commission on Human Rights/United Nations Human Rights Council, in: Wolfrum, Rüdiger (ed), Max Planck Encyclopedia of Public International Law (2007), paras. 1-24. 
Sarkin, Jeremy, A Critique of the Decision of the African Commission on Human and People's Rights Permitting the Demolition of the SADC Tribunal: Politics versus Economics and Human Rights (2016), 24, Afr J Int'l \& Comp L, pp. 215-241.

Saurombe, Amos, An Analysis and Exposition of Dispute Settlement Forum Shopping for SADC Member States in the Light of Suspension of the SADC Tribunal (2011), 23(3), South African Mercantile Journal, pp. 392-406.

Saurombe, Amos, The role of SADC institutions in implementing SADC Treaty provisions dealing with regional integration (2012), 15, Potchefstroom Elec LJ, pp. 454-484.

Sebalu, Paul, East African Community (1972), 16, Journal of African Law, pp. 345-363.

Senghor, Jeggan, The Treaty establishing the African Economic Community: an Introductory Essay (1993), 1, African Yearbook of International Law, pp. 183-193.

Shaffer, Gregory C., The World Trade Organization under Challenge: Democracy and the Law and Politics of the WTO's Treatment of Trade and Environment Matters (2001), 25, Harv Envt'l L Rev, pp.1-93.

Shehu, Sania, The roles on ECOWAS Parliament on Regional Integration of the West African Sub-Region, (2015), Int. j. Adm.Gov 1(4), pp. 119-122.

Skjelsbæk, Kjiell, The UN Secretary-General and the Mediation of International Dispute, 28 Journal of Peace Research 1 (1991), pp. 99-115.

Ssenyonjo, Manisuli, Direct Access to the African Court on Human and Peoples' Rights by Individuals and Non Governmental Organisations: An Overview of the Emerging Jurisprudence of the African Court 2008-2012 (2013), 2, Int'l Hum Rts L Rev, pp. 17-56.

Ssenyonjo, Manisuli; Nakitto, Saidat, The African Court of Justice and Human and Peoples' Rights International Criminal Law Section: Promoting Impunity for African Union Heads of State and Senior State Officials? (2016), International Criminal Law Review, pp. 71-102.

Steyn, Peter, Africa’s First Supranational Competition Authority Commences Operations: Issues Arising from the New COMESA Merger Control Regime (2013), 9, Competition International Law Journal, pp. 137-147.

Swart, Mia, Alternative fora for human rights protection? An evaluation of the human rights mandates of African sub-regional courts (2013), Journal of South African Law, pp. 437-452.

Swart, Mia, Extending the Life of the SADC Tribunal Judicial Decisions (2013), 38, S Afr YB Int'l L, pp. 253-262. 
Tlakula, Adv Pansy, The African Commission on Human and Peoples' Rights: Promotion and Protection of Rights under the African Charter on Human and Peoples' Rights, Rule of Law, Regional and National Enforcement of Human Rights in Africa (2014), 39 Supplement, S Afr YB Int'l L, pp. 5-20.

Tomuschat, Christian, International Covenant on Civil and Political Rights, in: Wolfrum, Rüdiger (ed), Max Planck Encyclopedia of Public International Law (2010), paras 1-38.

Tomuschat, Christian, Lisbon Treaty (2011), in: Wolfrum, Rüdiger (ed), Max Planck Encyclopedia of Public International Law, paras 1-21.

Umozurike, U.O., The African Charter on Human and Peoples' Rights:

Suggestions for More Effectiveness (2007), 13, Ann Surv Int'l \& Comp L, pp. 179-190.

van der Mei, A. P., The advisory jurisdiction of the African Court on Human and Peoples' Rights (2005), 5, Afr Hum Rts LJ, pp. 27-46.

van der Merwe, Derek, Economic cooperation in Southern Africa: structures, policies, problems (1991), 24, The comparative and international law journal of Southern Africa, pp. 386-404.

van Weijen, Jan, COMESA, free trade area by October 2000 (2000), 24, International Trade Law \& Regulation, pp. 153-160.

Vandeginste, Stef, The African Union, constitutionalism and power-sharing (2013), Journal of African Law, pp. 1-28.

Viljoen, Frans, An Introduction to the Protocol to the African Charter on Human and Peoples' Rights on the Rights of Women in Africa (2009), 16, Wash \& Lee J Civil Rts \& Soc Just, pp. 11-46.

Viljoen, Frans, The Realisation of Human Rights in Africa through Sub-Regional Institutions (1999), 185, African Yearbook of International Law, pp. 185-214.

Viljoen, Frans; Baimu, Evarist, Courts for Africa: Considering the Co-Existence of the African Court on Human and Peoples' Rights and the African Court of Justice (2004), 22, Neth Q Hum Rts, pp. 241-268.

Viljoen, Frans, Louw, Lirette, State Compliance with the Recommendations of the African Commission on Human and Peoples' Rights, 1994-2004 (2007), 101, Am J Int'l L, pp. 1-34.

Welch, Claude E. Jr, The African Commission on Human and Peoples' Rights: A Five-Year Report and Assessment (1992), 14, Hum Rts Q, pp. 43-61.

Wolfrum, Rüdiger, International Law (2006) in: Rüdiger, Wolfrum (ed), Max Planck Encyclopedia of Public International Law, paras 1-92. 


\section{Internet sources}

A dialogue with Ambassador Gertrude Mongella, President of the Pan African Parliament, Southern African Regional Poverty Network (14 September 2014), available at: http://www.sarpn.org/documents/d0001076/.

A history of Pan-Africanism, $326 \mathrm{New}$ Internationalist (August 2000), available at: https://newint.org/features/2000/08/05/simply.

Andriamananjara, Soamiely, Understanding the importance of the Tripartite Free Trade Area , Africa in Focus (17 June 2015), available at: https://www. brookings.edu/2015/06/17/understanding-the-importance-of-the-tripartitefree-trade-area/.

Angila, Francis, Processes for Elections to the East African Legislative Assembly, Friedrich Ebert Stiftung (2004), available at: http://library.fes.de/pdf-files/ bueros/kenia/02119.pdf.

Barasa, Chaby; Case made for transformation of SADC PF into regional parliament, Tralac (18 May 2016), available at: https://www.tralac.org/ news/article/9691-case-made-for-transformation-of-sadc-pf-into-regionalparliament.html,

Barasa, Chaby, Southern Africa: Proposal for SADC Parliamentary Forum, All Africa (17 May 2016), available at: http://allafrica.com/ stories/201605170135.html.

Beheading the Monster, The Economist (22 August 2012), available at: https:// www.economist.com/baobab/2012/08/22/beheading-the-monster.

Belhassen, Souhayr, The African Court on Human and Peoples' Rights towards the African Court of Justice and Human Rights - Practical Guide, International Federation for Human Rights (April 2010), available at: https:// www.fidh.org/IMG/pdf/african_court_guide.pdf.

Black Farmer, Falls on Hard Times, Sunday Times South Africa (11 May 2011), available at: https://www.timeslive.co.za/sunday-times/lifestyle/2011-05-21black-farmer-falls-on-hard-times/.

Bonello, Rita, Comparative View - The Inter-American Commission of Human Rights and the African Commission of Human and Peoples' Rights, Academia (16 November 2015), available at: https://www.academia.edu/21827648/ Comparative_View_The_Inter_American_Commission_of_Human_Rights_ and_the_African_Commission_of_Human_and_Peoples.

Boré, Linda, Henkel, Felix, Disturbing a Cosy Balance? The ECOWAS Parliament's Rocky Road to Co-Decision, Friedrich Ebert Stiftung (2015), available at: http://library.fes.de/pdf-files/iez/11185.pdf.

Bösl, Anton and others, Monitoring Regional Integration in Southern Africa - Yearbook-, Vol. Vol. 8, Trade Law Centre for Southern Africa, Konrad Adenauer Foundation, Namibian Economic Policy Research (2008) available at: http://www.kas.de/wf/doc/kas_16110-1522-1-30.pdf?110125181323. 
Brabazon, James, Liberia: Liberians United for Reconciliation and Democracy (LURD), The Royal Institute of International Affairs (2003), available at: https://www.chathamhouse.org/sites/default/files/public/Research/Africa/ brabazon_bp.pdf.

Calls for SADC leaders to reinstate regional tribunal, The Citizen South Africa (17 August 2015), available at: http://citizen.co.za/530047/calls-for-sadc-leadersto-reinstate-regional-tribunal/.

Carmel, Rickard, African Court delivers a Landmark decision on statelessness, African Lii (16 May 2018), available at: https://africanlii.org/content/africancourt-delivers-landmark-decision-statelessness.

Chenga, Nelson; Southern Africa: SADC Tribunal Downgraded, All Africa (27 August 2015), available at: http://allafrica.com/stories/201508270542.html.

Comesa court underutilised, by regional lawyers in practice, The Citizen South Africa (2 August 2015) available at:http://www.thecitizen. co.tz/News/Comesa-court-underutilised--by-regional-lawyers-inpractice/-/1840340/2817352/-/qugyk9z/-/index.html.

Convention on the Rights of the Child, Child Rights International Network, available at: https://www.crin.org/en/home/rights/convention.

Davi, Tetevi, African Court on Human and Peoples' Rights Delivers Landmark Ruling on Women's Rights and the Rights of the Child in Mali, EJIL: Talk! (27 July 2018) available at: https://www.ejiltalk.org/african-court-on-humanand-peoples-rights-delivers-landmark-ruling-on-womens-rights-and-therights-of-the-child-in-mali/.

Davis, Abednego, West Africa: ECOWAS Court Of Justice For Everybody All Africa (30 January 2017), available at: https://allafrica.com/ stories/201701300627.html.

Dersso, Solomon, South Africa's future in the ICC is still uncertain, Aljazeera (13.03.2017), available at: http://www.aljazeera.com/indepth/ opinion/2017/03/south-africa-future-icc-uncertain-170313122508594.html.

Dube, Memory; Midgley, Rob, Land reform in Zimbabwe: context, process, legal and constitutional issues and implications for the SADC region in: Bösl, Anton and others (eds), Monitoring Regional Integration in Southern Africa - Yearbook -, Trade Law Centre for Southern Africa, Konrad Adenauer Foundation, Namibian Economic Policy Research (2008), available at: http:// www.kas.de/wf/doc/kas_16110-1522-1-30.pdf?110125181323, pp. 303-341.

ECOWAS and the Subregional Peacekeeping in Liberia, The Journal of Humanitarian Assistance (25 September 1995), available at http://sites.tufts. edu/jha/archives/66. 
ECOWAS Community Court of Jusitce Holds Nigerian Government Liable for Human Rights Violations by Oil Companies Human Rights Brief, SERAP v. Federal Republic of Nigeria, ECW/CCJ/JUD/18/12, Judgement of 14 December 2012.

ECOWAS Court rules Gambia violated rights of journalists, Committee to Protect Journalists (14 February 2018) available at: https://cpj.org/2018/02/ ecowas-court-rules-gambia-violated-rights-of-journ.php.

Erasmus, Gerhard, How will the AfCFTA be established an ist Legal instruments be implemented? available at: https://www.tralac.org/discussions/ article/12869-how-will-the-afcfta-be-established-and-its-legal-instruments-beimplemented.html.

Erasmus, Gerhard; The COMESA Court of Justice clarifies important Jurisdictional Issues, Tralac (16 November 2017), available at: https://www. tralac.org/discussions/article/12412-the-comesa-court-of-justice-clarifiesimportant-jurisdictional-issues.html\#_ftn6.

Erasmus, Gerhard, The New Protocol for the SADC Tribunal: Jurisdictional Changes and Implications for the SADC Community Law , Tralac Working Paper (2015), available at: https://www.tralac.org/publications/article/6900the-new-protocol-for-the-sadc-tribunal-jurisdictional-changes-andimplications-for-sadc-community-law.html.

Erasmus, Gerhard; The Polytol judgement of the COMESA Court of Justice: Implications for rules-based integration, Tralac (1 July 2015), available at: https://www.tralac.org/publications/article/7604-the-polytol-judgment-ofthe-comesa-court-of-justice-implications-for-rules-based-regional-integration. html.

European Commission for Democracy through Law (Venice Commission), Report on the Rule of Law of 2011, 86th session, Venice, Italy, available at: http://www.venice.coe.int/webforms/documents/default.aspx?pdffile=CDL$\operatorname{AD}(2011) 003$ rev-e.

FACTBOX-Sudan's President President Omar Hassan al-Bashir, Reuters, available at: https://www.reuters.com/article/uk-warcrimes-sudan-bashir-profile/ factbox-sudans-president-omar-hassan-al-bashir-idUKL1435274220080714.

Folfas, Jan Pawel; Garlińska-Bielawska, Joanna; Can the Tripartite Free Trade Area (TFTA) Agreement Become a Breakthrough Arrangement in Regional Integration on the African Continent?, Acta Universitas Lodziensis (2018), available at: https://www.researchgate.net/profile/Pawel_Folfas/ publication/323527234_Czy_Porozu_mienie_Tripartite_Free_Trade_Area_ TFTA_moze_stac_sie_przelomowe_w_procesie_integracji_regionalnej_ na_kontynencie_afrykanskim/links/5aa0f2cf0f7e9badd9a3c3a8/CzyPorozumienie-Tripartite-Free-Trade-Area-TFTA-moze-stac-sie-przelomowew-procesie-integracji-regionalnej-na-kontynencie-afrykanskim.pdf. 
Fritz, Nicole; Quiet death of an important SADC institution, Mail \& Guardian (29 August 2014), available at: https://mg.co.za/article/2014-08-29-quietdeath-of-an-important-sadc-institution.

Gberie, Lansana, Special Court of Siera Leone rests - for good, AfricaRenewal (April 2014), available at: https:/www.un.org/africarenewal/magazine/ april-2014/special-court-sierra-leone-rests-\%E2\%80\%93-good.

Gezahegn, Bantayehu D., The International Criminal Court and the African Union: A Deadlock where Power Politics Paralyzes International Law, Human Rights Brief, available at: http://hrbrief.org/hearings/the-internationalcriminal-court-and-the-african-union-a-deadlock-where-power-politicsparalyzes-international-law/.

Hartmann, Christof, Governance Transfer by the Economic Community of West African States (ECOWAS), German Reasearch Foundation (2013), available at: http://www.sfb-governance.de/publikationen/sfb-700-working_papers/ wp47/SFB-Governance-Working-Paper-47.pdf.

Hartzenberg, Trudi.; Erasmus, Gerhard et al, The Tripartite Free Trade Area, Towards a New African Integration Paradigm?, Trade Law Centre for Southern Africa and Swedish International Development Cooperation Agency (2012), available at: http://www.ictsdsymposium.org/wp-content/ uploads/bsk-pdf-manager/10_The-TFTA-towards-a-new-African-integrationparadigm_20131017.pdf.

Hartzenberg, Trudi, Regional Integration in Africa (2011), World Trade

Organization, Economic Research and Statistics Division, (2011), available at: https://www.wto.org/english/res_e/reser_e/ersd201114_e.pdf.

Hessbruegge, Jan A., ECOWAS Court Judgement Habré v. Senegal Complicates Prosecution in the Name of Africa, American Society of International Law (03 February 2011), available at: https://www.asil.org/insights/volume/15/issue/4/ ecowas-court-judgment-habr\%C3\%A9-v-senegal-complicates-prosecutionname-africa.

Hondora, Tawanda, The Establishment of the SADC Tribunal: Troubled Beginnings (2010), available at: https://papers.ssrn.com/sol3/papers. cfm?abstract_id=1727342.

Human Rights Watch, Failing Darfur - Entrenching Impunity: Government Responsibility for International Crimes in Darfur; available at: https://www. hrw.org/legacy/features/darfur/fiveyearson/report4.html.

Human Rights Watch, Regional Court's Future Hangs in Balance, available at: https:/www.hrw.org/sites/default/files/related_material/SADC\%20tribunal_ QA_Final\%20Post $\% 20$ HRWPress.pdf.

Institute for Human Rights and Development and Others v Democratic Republic of Congo, Communication 393/10, ESCR-Net, available at: https://www. escr-net.org/caselaw/2018/institute human-rights-and-development-andothers-v-democratic-republic-congo. 
International Democracy Watch; SADC Parliament, available at: http://www. internationaldemocracywatch.org/index.php/sadc-parliament.

Itodo, Yemi, ECOWAS Parliament salutes Ekweremadu on enhancement of its powers, Daily Post, (28 February, 2017) available at: http://dailypost. ng/2017/02/28/ecowas-parliament-salutes-ekweremadu-enhancementpowers/.

Joseph, Abraham, Why the South African High Court Ruling on ICC Withdrawal IS Significant for International Law The Wire (28 February 2017), available at: https://thewire.in/112372/why-south-african-high-courtruling-on-icc-withdrawal-is-significant-for-international-law/.

Kersten, Mark, What Gives? African Union Head of State Immunity, Justice in Conflict, (7 July 2014), available at: https://justiceinconflict.org/2014/07/07/ what-gives-african-union-head-of-state-immunity/.

Konopo, Joell, Madagascar joins SADC while Rwanda fails, All Africa

(17 August 2015), available at: https://www.mmegi.bw/2005/August/ Wednesday17/426374890200.html.

Ligami, Christabel, EACJ to handle criminal offences, The East African (07 December 2013), available at: http://www.theeastafrican.co.ke/news/EACJto-handle-criminal-offences/2558-2103006-w3mjrs/index.htm.

Luke, David; Mabuza, Zodwa, The Tripartite Free Trade Area Agreement: A milestone for Africa's regional integration process, International Centre for Trade and Sustainable Development (23 June 2015), available at: https:// www.tralac.org/resources/by-region/comesa.html.

Magaisa, Alex T, Constitution Flash- Agricultural Land in the draft Constitution, Commercial Farmers Union of Zimbabwe (07 August 2012), available at: http:/www.cfuzim.org/index.php/newspaper-articles-2/constitution/2847constitution-flash-agricultural-land-in-the-draft-constitution.

Magbagbeola, Nelson O., Status of enhancement of powers of a regional Parliament: evidence from ECOWAS Parliament, Inter Parliamentary Union (October 2016), available at: https://www.asgp.co/sites/default/files/ ECOWAS\%20SG\%27s\%20Presentation\%20to\%20ASGP\%20Meeting\%20 in\%20October\%202016.pdf.

Magdaza, Moses, Sadc PF Plenary ups momentum The Herald (19 December 2017), available at: http://www.herald.co.zw/sadc-pf-plenary-upsmomentum/.

Majaha, Daniel; Proposed SADC regional parliament garners support, The Southern Times (23 August 2016), available at: https://southerntimesafrica. $\mathrm{com} /$ site/news/proposed-sadc-regional-parliament-garners-support.

Marawa, Amos, The COMESA Air Transport Liberalization Experience, ICAO (March 2003), available at: http://www.icao.int/Meetings/ATConf5/ Documents/Marawa.pdf. 
Maromo, Jonisayi, Zuma's role in dismantling SADC Tribunal slammed by court, IOL News (01 March 2018), available at: https://www.iol.co.za/news/ south-africa/gauteng/zumas-role-in-dismantling-sadc-tribunal-slammed-bycourt-13543070.

Mugisa, Evarist; Onyango, Chris; Mugoya, Patrick, An Evaluation of the Implementation and Impact of the East African Community Customs Union, Academia (March 2009), available at: https://www.academia.edu/27637527/ An_Evaluation_of_the_Implementation_and_Impact_of_the_East_African_ Community_Customs_Union.

Musavengana, Takawira, The proposed SADC Parliament - Old wine in new bottles or an ideal whose time has to come?, Institute for Security Studies (28 July 2011), available at: https://oldsite.issafrica.org/publications/monographs/ the-proposed-sadc-parliament-old-wine-in-new-bottles-or-an-ideal-whosetime-has-come.

Muyangwa, Monde, Vogt, Margaret A., An Assessment of the OAU Mechanism for Conflict Prevention, Management and Resolution, 1993-2000 (2002), available at: https://www.ipinst.org/wp-content/uploads/publications/oau_ conflict_1993_2000.pdf.

Mwanza, William, Polytol Paints v Mauritius: Evidence of the existence and direct effect of community law in COMESA?, Tralac, (29 January 2014) available at: https:/www.tralac.org/publications/article/5551-polytol-paints-v-mauritiusevidence- of-the-existence-and-direct-effect-of-community-law-in-comesa. html.

Ndlovu, Ray, Sadc Tribunal back with mandate reduced to interstate cases, Business Live South Africa (20 August 2014), available at: http://www.bdlive. co.za/africa/africannews/2014/08/20/sadc-tribunal-back-with-mandatereduced-to-interstate-cases.

Nwauche, Enynna S, Regional economic communities and human rights in West Africa and the African Arab countries', Konrad Adenauer Stiftung, available at: https://www.kas.de/c/document_library/get_file?uuid=15d35401-4cdda11e-9c1e-f1035afeafa3\&groupId=252038.

Official Website of Paul Kagame, available at: http://paulkagame.com/.

Official Website of the African Court of Human and Peoples' Rights: available at: http://www.african-court.org/en/.

Official Website of the African Commission, Ratification Table: African Charter on Democracy, Elections and Governance, available at: http://www.achpr.org/ instruments/charter-democracy/ratification/.

Official Website of the African Development Bank Group, Mano River Union Capacity Building and Technical Assistance Institutional Strengthening, available at: https://www.afdb.org/en/projects-and-operations/projectportfolio/p-z1-kf0-019/. 
Official Website of the Civic United Front: available at: https://cuftz.com/. Official Website of the COMESA COurt of Justice, The COMESA Court of Justice rules that Mauritius breached the COMESA rules for the Free Trade Area and orders a refund of customs duties to a small company, (16 October 2015), available at: comesacourt.org/the-comesa-court-of-justice-rules-thatmauritius-breached-the-comesa-rules-for-the-free-trade-area-and-orders-arefund-of-customs-duties-to-aTrade Mark Southern Africa-small-company-2/.

Official Website of the Common Market of Eastern and Southern Africa, Comesa Court underutilised, Senior Counsel Nzamba Kitonga says, available at: http://www.nation.co.ke/news/Comesa-court-underutilised-NzambaKitonga-/-/1056/2816492/-/xo384z/-/index.html.

Official Website of the East African Legislative Assembly, EALA Set to Visit 5 Countries as It Starts Kenya Tour, available at: http://www.eala.org/new/ index.php/media-centre/press-releases/632-eala-set-to-visit-5-counties-as-itstarts-kenya-tour.

Official Website of the Intergovernmental Authority on Development, available at: https://igad.int/.

Official Website of the Law Society South Africa, SADC Tribunal Matter: available at: http://www.lssa.org.za/our-initiatives/advocacy/sadc-tribunalmatter.

Official Website of the Pan-African Parliament, PAP President urges journalists to lobby for ratification of Malabo Protocol, available at: http://www. panafricanparliament.org/news/283-pap-president-urges-journalists-to-lobbyfor-ratification-of-malabo-protocol.

Official Website of the Parlement de la CEDEAO/ECOWAS https://parl.ecowas. int/committees/.

Official Website of the Revolutionary Party of Tanzania: https:/www.britannica. com/topic/Revolutionary-Party-of-Tanzania.

Official Website of the SADC Parliamentary Forum, Vision and Mission, available at: http://www.sadcpf.org/index.php?option=com_content $\&$ view=article\&id= 86: vision-and- mission\&catid=39:about-us\&Itemid=105.

Official Website of the Southern African Development Community (SADC), available at: https://www.sadc.int/.

Official Website of the Tralac Trade Law Centre 'African Continental Free Trade Area (AfCFTA) Legal Texts and Policy Documents', available at: https://www. tralac.org/resources/by-region/cfta.html.

Official Website of the United Nations, International Residual Mechanism for Criminal Tribunals, available at: http://unictr.irmct.org/.

Official Website of the United Nations Population Fund, Landmark move against child marriage (20 June 2016), available at: https://esaro.unfpa.org/en/news/ landmark-move-against-child-marriage. 
Official Website of the United Nations, Treaty Collection: https:// treaties.un.org/pages/ViewDetails.aspx?src=IND\&mtdsg_no=XVIII7\&chapter=18\&clang=_enhttps://www.ohchr.org/en/professionalinterest/ pages/crimeofgenocide.aspx.

Official Website of the United Nations; United nations Security Council, available at: https://www.un.org/securitycouncil/.

Osisioma, Cajetan, Is the ECOWAS Court of Justice a Toothless Bulldog that Only Barks? Issues Arising from the Decision of the High Court of Ghana Mr. Chude Mba v The Republic of Accra, (09 May 2016), available at: https:/www.mondaq.com/nigeria/international-trade-investment/489494/ is-the-ecowas-court-of-justice-a-toothless-bulldog-that-only-barks-issuesarising-from-the-decision-of-the-high-court-of-accra-in-mr-chude-mba-v-therepublic-of-ghana?

Olofin, Sam, A survey of the capacity needs of Africa's Regional Economic Communities, Africa Platform (01 July 2008), available at: http://www.africaplatform.org/resources/survey-capacity-needs-africas-regional-economiccommunities-executive-summary.

Otiento, Mbori, The merged African Court of Justice and Human Rights (ACJ\&HR) as a better criminal justice system than the ICC: Are we Finding African Solution to African problems of creating African problems without solution? Academia, available at: https://www.academia.edu/7237572/ The_merged_African_Court_of_Justice_and_Human_Rights_ACJ_and_ HR_as_a_better_criminal_justice_system_than_the_ICC_Are_we_Finding African_Solutions_to_African_problems_or_creating_African_problems_ withoutsolutions.

Patinkin, Jason, Uhuru Kenyatta's election victory is upheld by Kenya's supreme court, The Guardian (30 March 2013), available at:https://www.theguardian. $\mathrm{com} /$ world $/ 2013 / \mathrm{mar} / 31 /$ kenya-court-upholds-kenyatta-victory.

Pecorella, Giulia, The African Court on Human and Peoples' Rights and its case law: towards a Supreme Court for Africa?, International Law Blog ( 22 June 2015), available at: https://aninternationallawblog.wordpress. com/2015/06/22/the-african-court-on-human-and-peoples-rights-and-itscase-law-towards-a-supreme-court-for-africa.

Peter-Berries, Christian, Regional Integration in Southern Africa - A Guidebook, on behalf of Federal Ministry for Economic Cooperation and Development, Germany (2010), available at: http://iaj.org.za/wp-content/uploads/2017/06/ sadc__guidebook_for_regional_integration 11.pdf.

Possi, Ally; It's official: The East African Court of Justice can now adjudicate human rights cases, AfricLAW (01 February 2016), available at: https:// africlaw.com/2016/02/01/its-official-the-east-african-court-of-justice-cannow-adjudicate-human-rights-cases/. 
Promoting the AU Charter On Democracy Elections and Governance in West Africa, WAEON I West Africa Elections Observer Network (2013) available at: https://www.ndi.org/WAEON-symposium.

Quan, Gertrude M., Rising against the silencing of the SADC Tribunal: Tanzania, AfricLaw (5 June 2015), available at: https://africlaw.com/2015/06/05/risingagainst-the-silencing-of-the-sadc-tribunal-tanzania.

Randall, Estelle, SADC urges pan-African parliament debate, IOL (21 April 2000), available at: https://www.iol.co.za/news/africa/sadc-urges-pan-africanparliament-debate-35232.

SADC-EAC-COMESA Tripartite Free Trade Area Legal Texts and Policy Documents, Tralac, available at: https:/www.tralac.org/resources/ourresources/4856-sadc-eac-comesa-tripartite-free-trade-area-legal-texts-andpolicy-documents.html.

SADC Parliamentarians adopt Model Law on eradicating child marriage, Girls not Brides (4 June 2016), available at: https://www.girlsnotbrides.org/sadcmodel-law-child-marriage/.

Sendolo, Joaquin, Sensitize Liberians on ECOWAS’ Mission, Liberian Daily Observer (2 February 2017), available at: https://www.liberianobserver.com/ news/sensitize-liberians-on-ecowas-mission/.

Shinyeka, Isaac, Othieno, Lawrence, Prospects and Challenges in the formation of the COMESA-EAC and SADC Tripartite Free Trade Area, Africa Portal (11 November 2011), available at: https://www.africaportal.org/publications/ prospects-and-challenges-in-the-formation-of-the-comesa-eac-and-sadctripartite-free-trade-area/.

Southern African Development Community Parliamentary Forum, Strategic Plan, 2006-2010, available at: http:/www.internationaldemocracywatch.org/index. $\mathrm{php} /$ southern-africa-development-community-other-documents/168-sadcparliamentary-forum-strategic-plan-2006-2010.

Southern Africa: SADC Parly for Regional Integration, All Africa (4 June 2004), available at: https://allafrica.com/stories/200406040936.html.

Terlinden, Ulf, African Regional Parliaments / Parliamentary Bodies as Engines of Integrations: Current State and Challenges, Roundtable on the interface between Regional Parliamentary Assemblies and the Pan African Parliament (PAP), 2005, Lusaka, Zambia, available at: http://www.ulf-terlinden.de/ docs/2005-08SADCPF_RAs_Lusaka.pdf.

Ubwani, Zephania, Lawyers in push for more regional court powers. The Citizen, Tanzania (2 February 2014), available at: http://www.thecitizen.co.tz/News/ Lawyers-in-push-for-more-regional-court-powers/1840340-2169666-pipeyd/ index.html.

United Nations Economic Commission for Africa - Overview; available at: https://www.uneca.org/pages/overview. 
United Nations - Africa; available at: https://www.un.org/en/sections/where-wework/africa/index.html.

Usman, Samson Atekojo Saraki tasks ECOWAS Parliament on regional integration, security, Daily Post Nigeria (13 July 2016), available at: http:// dailypost.ng/2016/07/13/saraki-tasks-ecowas-parliament-on-regionalintegration-security/.

Viljoen, Frans, AU Assembly should consider human rights implications before adopting the Amending Merged African Court Protocol AfricaLaw (23 May 2012), available at: https://africlaw.com/2012/05/23/au-assembly-shouldconsider-human-rights-implications-before-adopting-the-amending-mergedafrican-court-protocol/.

Viljoen, Frans, Centre for Human Rights Calls for more Reflection on ICC Withdrawal, (14 October 2015), available at: https://www.up.ac.za/en/ faculty-of-law/news/post_2175625-centre-for-human-rights-calls-for-morereflection-on-icc-withdrawal.

Wanyama, Leonard, The Economic Diplomacy of Kenya's Regional Interests (2013), SAIIA Occasional Paper No 137, available at: http://www.saiia.org.za/ research/the-economic-diplomacy-of-kenyas-regional-interests/.

West Africa: Amb. Conteh Addresses ECOWAS Parliament, All Africa ( 12 May 2017), available at: https://allafrica.com/stories/201705120746.html.

Wily, Liz Alden; African court's ruling gives hope to rural people across the continent, The Conversation (19 June 2017), available at: http:// theconversation.com/african-courts-landmark-ruling-gives-hope-to-ruralpeople-across-the-continent-79303.

Windridge, Oliver, No Need to Sign: Testing the Special Declaration at the East African Community Court of Justice, ACtHPR Monitor (17 September 2015), available at: http://www.acthprmonitor.org/no-need-to-sign-testingthe-special-declaration-at-the-east-african-community-court-of-justice/.

Women Informal Cross Border Traders: Opportunities and Challenges in the East African Community - An Action Research, Eastern African Sub-regional Support Initiative for the Advancement of Women (EASSI), (2012), available at: https://www.eassi.org/wp-content/uploads/2018/08/Women-InformalCross-Border-Traders-Opportunities-and-Challenges-in-the-EAC-Actionresearch-2012.pdf.

Zinzindohoué, Abraham D, Autorité jurisdictionelle des cours internationales à l'égard des courts nationales: le cas de la Cour de justice de l'UEMOA in AHJUCAF Internationalisation du Droit, Interantionalisation de la Justice Actes du troisieme Congrès de l'AHJUCAF (21-23 juin 2010), available at: http://v1.ahjucaf.org/IMG/pdf/Internationalisation_du_droit.pdf. 
The protection of human rights and popular participation on the first sight seem to contradict the often-existing image of the African continent. However, with the foundation of the African Union in 2000, both aspects gain greater importance on regional level. Besides that, many subregional courts within the sphere of sub-Sahara Africa partially started to develop human rights-related jurisdiction. In addition to that, most regional economic communities nowadays provide for their own parliamentary structures. The study aims to examine the several institutional structures and their competences on both, regional and subregional level. Besides that, it provides for a profound analysis of the jurisdiction of the respective courts as well as the communications of the African Commission of Human and Peoples' Rights. Lastly, the study focuses on the correlation between the extension of the institutions' competences and the political will of the involved governments. 